\title{
Chronostratigraphic and palaeogeographic significance of an early Cambrian microfauna from the Heraultia Limestone, northern Montagne Noire, France
}

\author{
Léa Devaere, Sébastien Clausen, Michael Steiner, J. Javier Álvaro, \\ and Daniel Vachard
}

\begin{abstract}
Abundant and diverse Small Shelly Fossils (SSFs) have been reported in Northern Montagne Noire (Southern France) since the last $20^{\text {th }}$ century from early Cambrian phosphatic carbonates called Heraultia Limestone. This assemblage includes Watsonella crosbyi, a mollusc with high-potential for the definition of the base of the Cambrian Stage 2, as recently emphasized by the Cambrian Stage Subdivision Working Group of International Commission of Stratigraphy. Nevertheless, the Heraultia Limestone is traditionally considered Cambrian Stage 3 to 4 based on questionnable lithological correlations among different tectonostratigraphic units. The focus of this paper is to re-evaluate the age and the paleogeographical significance of the Heraultia Limestone in the light of recent advances in SSF systematic and biostratigraphy. Reassessed assemblage is dominated by molluscs (helcionellids, ?polyplacophors and other problematic taxa), and abundant orthothecid hyoliths, problematic tubes; few problematica are also present. Twenty-eight species and three morphotypes are described. Two species and one genus are new (Obscurania tormoi Devaere, sp. nov.; Alaconcha Devaere, gen. nov. and Alaconcha rugosa Devaere, sp. nov.), seven are reported for the first time. Among previously mentionned species, 13 are reassigned, 7 confirmed, and 9 unrecovered from the studied sampled. The global stratigraphic range of each species is established based on updated inventory of known occurrences. It argues for a Terreneuvian (Nemakit-Daldynian/Tommotian according to the Siberian stratigraphic chart) age of the microfossil assemblage. The Watsonella crosbyi-Oelandiella korobkovi Interval Zone is defined and is correlated with base of Cambrian Stage 2 (Tommotian) of Siberia, China, Mongolia, and Avalonia. The Northern Montagne Noire would accordingly witness for one of the earliest, isolated but consequent Tommotian carbonate-platform on the Western Gondwana margin. As a result, present tectonic and palaeogeographic models have to be emended, and factors that favored such isolated platforms should be further investigated.
\end{abstract}

PE Article Number: 16.2.17A

Copyright: Palaeontological Association July 2013

Submission: 14 December 2012. Acceptance: 23 June 2013

Devaere, Léa, Clausen, Sébastien, Steiner, Michael, Álvaro, J. Javier and Vachard, Daniel. 2013. Chronostratigraphic and palaeogeographic significance of an early Cambrian microfauna from the Heraultia Limestone, northern Montagne Noire, France, Palaeontologia Electronica Vol. 16, Issue 2; 17A; 91p;

palaeo-electronica.org/content/2013/298-french-cambrian-microfauna

http://zoobank.org/08BB3E43-45C0-4C04-A08F-C1D7632E1154 
Léa Devaere. UMR 8217 Géosystèmes CNRS-Université LILLE 1, F59655 Villeneuve d'Ascq, France, lea.devaere@ed.univ-lille1.fr.

Sébastien Clausen. UMR 8217 Géosystèmes CNRS-Université LILLE 1, F59655 Villeneuve d'Ascq, France, sebastien.clausen@univ-lille1.fr.

Michael Steiner. Department of Earth Sciences, Freie Universität Berlin, Malteserstrasse 74-100, Haus D, Berlin, 12249, Germany, steiner@zedat.fu-berlin.de.

J. Javier Álvaro. Centro de Astrobiología (CSIC/INTA), Ctra. de Torrejón a Ajalvir, km 4, 28850 Torrejón de Ardoz, Spain, alvarobjj@cab.inta-csic.es.

Daniel Vachard. UMR 8217 Géosystèmes CNRS-Université LILLE 1, F59655 Villeneuve d'Ascq, France, daniel.vachard@univ-lille1.fr.

Keywords: New genus; new species; Terreneuvian; Small Shelly Fossils; Biostratigraphy; western Gondwana

\section{INTRODUCTION}

Apart from some rare late-Ediacaran taxa, the skeletal microfossils recovered from earliest Cambrian carbonate platforms are the first remains of true biomineralising metazoans encountered in the fossil record. These skeletonised microfossils and disarticulated sclerites were first called "Small Shelly Fossils" (SSFs) by Matthews and Missarzhevsky (1975), who continued the accurate work of Rozanov and Missarzhevsky (1966) and Rozanov et al. (1969) about the Cambrian of the Siberian Platform. Furthermore, pioneer investigators had already suggested an overview of their palaeobiological and geological importance (Billings, 1871, 1872; Shaler and Foerste, 1888; Walcott, 1890; Moberg, 1892; Matthew, 1886, 1899; Cobbold, 1919, 1921, 1931, 1935, 1936; Cobbold and Pocock, 1934; Daily, 1956; Ahman and Martinsson, 1965; Fonin and Smirnova, 1967; Poulsen, 1967). The SSFs were firstly considered as problematic metazoans although poriferan, mollusc, and hyolith affinities were proposed by Matthews and Missarzhevsky (1975). Numerous subsequent studies of early Cambrian SSFs have been conducted, mostly from the Siberian platform (Sokolov et al., 1974; Sokolov and Zhuravleva, 1983; Khomentovsky and Karlova, 1993) and Yangtze platforms (Qian, 1977, 1978a, 1978b, 1984, 1989; Yu, 1979, 1987b; Jiang, 1980a, 1980b, 1984; Yin et al., 1980; Luo et al., 1980, 1982, 1984; Xing et al., 1984; Qian and Bengtson, 1989; Steiner et al., 2004; Parkhaev and Demidenko, 2010), but also from Mongolia (Voronin et al., 1982; Esakova and Zhegallo, 1996), Kazakhstan (Missarzhevsky and Mambetov, 1981), India (Azmi and Pancholi, 1983; Bhatt et al., 1985; Brasier and Singh, 1987), Pakistan (Mostler, 1980), Iran (Hamdi et al., 1989), and France (Kerber,
1988). This polyphyletic informal group characterises the widely distributed "Tommotian Fauna", named after the early Cambrian stage of the regional Siberian chart (equivalent to the upper part of the Terreneuvian; Spizharski et al., 1986; Landing et al., 2007). The Terreneuvian or pre-trilobitic Cambrian is otherwise devoid of trilobites and archaeocyaths. The latter are the usual Cambrian biostratigraphic-markers, but they are restricted to the Siberian platform at that time. Consequently, the global stratigraphic subdivision of the lowermost Cambrian strata remains to be defined and requires continued attention (Babcock and Peng, 2007). Recently, Zhu et al. (2008) proposed a provisional definition for the base of Cambrian Stages 2 to 4 and, after the "XIII International Field Conference of the Cambrian Stage Subdivision Working Group" that took place in the Lena River, Siberia (Yakutia, Russia), three Working Groups on lower Cambrian Global Boundary Stratotype Section and Points (GSSP) were established, including the Working Group on Stage 2 (upper Terreneuvian) GSSP (Peng and Babcock, 2011). Zhu et al. (2008) emphasised the high stratigraphic potential of SSFs for the biostratigraphic subdivision of the Terreneuvian, and suggested the FAD of Watsonella crosbyi (a mollusc), to erect the base of the provisional Cambrian Stage 2. Rozanov et al. (2008) proposed the FAD of Aldanella attleborensis, another widely distributed mollusc, to define this boundary.

Precise phylogenetic affinities of many SSFs are still uncertain or debated. Moreover, their taxonomy is part-based (parataxonomy; Bengtson, $1985 b)$ due to their generally fragmentary preservation. However, such weaknesses are common among other successful biostratigraphic markers (e.g., conodonts) and many regional zonations of the Terreneuvian have already been established 
based on SSFs, such as those of Kazakshtan (Missarzhevsky and Mambetov, 1981), Siberia (Rozanov, 1984), West Avalonia (Landing, 1988), Mongolia (Esakova and Zhegallo, 1996) and, more recently, North and South China (Steiner et al., 2007). Nevertheless, the taxa are problematically compared between various platforms. This poor resolution is mainly due to the diverging taxonomic concepts selected by different authors. The SSF diversity has undoubtedly been overestimated by poor integration of intraspecific variability in the early definitions of morphotaxa. Despite these biases, successive generic and specific revisions and interregional correlations point to the FAD of $W$. crosbyi and $A$. attleborensis as the best candidates for the definition of the base of Cambrian Stage 2 (Landing et al., 2007; Steiner et al., 2007; Rozanov et al., 2008; Peng, 2009; Li et al., 2011; Parkhaev and Karlova, 2011; Parkhaev et al., 2011; Kouchinsky et al., 2012; Parkhaev et al., 2012). The FAD of $W$. crosbyi has already been correlated across China, Siberia, Mongolia, and Newfoundland (Li et al., 2011) and is still considered the provisional stratigraphic tie point for the base of Cambrian Stage 2 (Peng and Babcock, 2011).

In the western Mediterranean region, correlation of the Cambrian Stage 1-2 boundary has been an everlasting matter of discussion due to lithoand biostratigraphic misleading assumptions. In the northern Montagne Noire, southern France, $W$. crosbyi, originally described as Heraultia varensalensis by Cobbold (1935), was reported by Kerber (1988) in a phosphatic limestone unit, up to $60 \mathrm{~m}$ thick, named "Calcaire à annélides et phyllopodes," "Saint-Geniès-de-Varensal Limestone," or "Heraultia Limestone" (Bergeron, 1889; Cobbold, 1935; Thoral, 1935; Bogdanoff et al., 1984; Kerber, 1988). Based on lithostratigraphic comparisons, the Heraultia Limestone is considered as the middle member of a thick, dolostone-dominated unit of $900 \mathrm{~m}$ in thickness, traditionally correlated with the "massive carbonate" (Donnot and Guérangé, 1978), "masse carbonatée" (Courtessole, 1973), or Lastours Formation (Álvaro et al., 1998), the latter dated as Atdabanian/Botoman (Cambrian Series 2, Stages 3 and 4) based on archaeocyaths (Debrenne, 1964, Debrenne and Courjault-Radé, 1994) and, once distinguished the Pardailhan and Lastours formations, Botoman/Toyonian (Cambrian Stages 4 and 5) based on archaeocyaths and trilobites (Álvaro et al., 1998).

After a detailed analysis of the sedimentological and petrographic characters of the Heraultia
Limestone (Clausen and Álvaro, 2007; Álvaro and Clausen, 2010), a deep revision of its microfossil content seemed necessary. The aim of this paper is to reassess the fossil assemblage of the Heraultia Limestone in the light of recent advances in SSF systematics, biostratigraphy, and palaeobiogeography. Determining whether the phosphatic limestone that encloses the assemblage is correctly dated and whether the global stratigraphic range of $W$. crosbyi is properly understood is the goal of the present study. Original Kerber collection was not localised and made available for this study, which is therefore based on a new and exhaustive sampling of four logs measured in the Avène-Mendic parautochthon of the northern Montagne Noire, France. The 87 samples selected by the authors provided most but not all of the taxa illustrated by Kerber (23 out of 34 , some of which are below reassigned or synonimised), in addition to eight new ones. Published occurrences of recovered taxa are extensively reviewed, and a detailed international correlation of the Heraultia Limestone with other subtropical early Cambrian platforms, from which SSFs have been reported, is provided.

\section{GEOLOGICAL SETTING AND STRATIGRAPHY}

The Montagne Noire is a segment of the southern French external zones of the Variscan belt, located in the southern end of the Massif Central (Figure 1.1). Ilt constitutes a Variscan massif surrounded by post-orogenic sediments from Gzhelian Stage (formerly Stephanian; uppermost Carboniferous) upwards. Bergeron (1887) and Gèze (1949) subdivided the Montagne Noire into three main structural domains (Figure 1.2): (1) a metamorphic Axial Zone, composed of Proterozoic and lower Palaeozoic migmatized gneisses and micaschists (Demange, 1998), sandwiched between: (2) a southern flank, constituted of several large nappes including lower Cambrian to Carboniferous rocks, and (3) a northern flank, involving lower Cambrian to Silurian strata arranged in imbricated tectonic slices (GuérangéLozes and Burg, 1990). The Lacaune Mountains of the northern flank, in contact with the Axial Zone, is composed of five major tectonostratigraphic units, from SE to NW: the Avène-Mendic parautochthon and the Mélagues, Brusque, Merdellou, and BarrePeux-Mounes units (Figure 1.3). These slices consist of large-scale, SE-verging, recumbent, NESW-striking folds (Figure 2). They are separated by large-scale NE-SW overlaps inclined toward NW (Figure 2) and resulted from tangential shear stresses related to the Variscan Orogeny. The Her- 


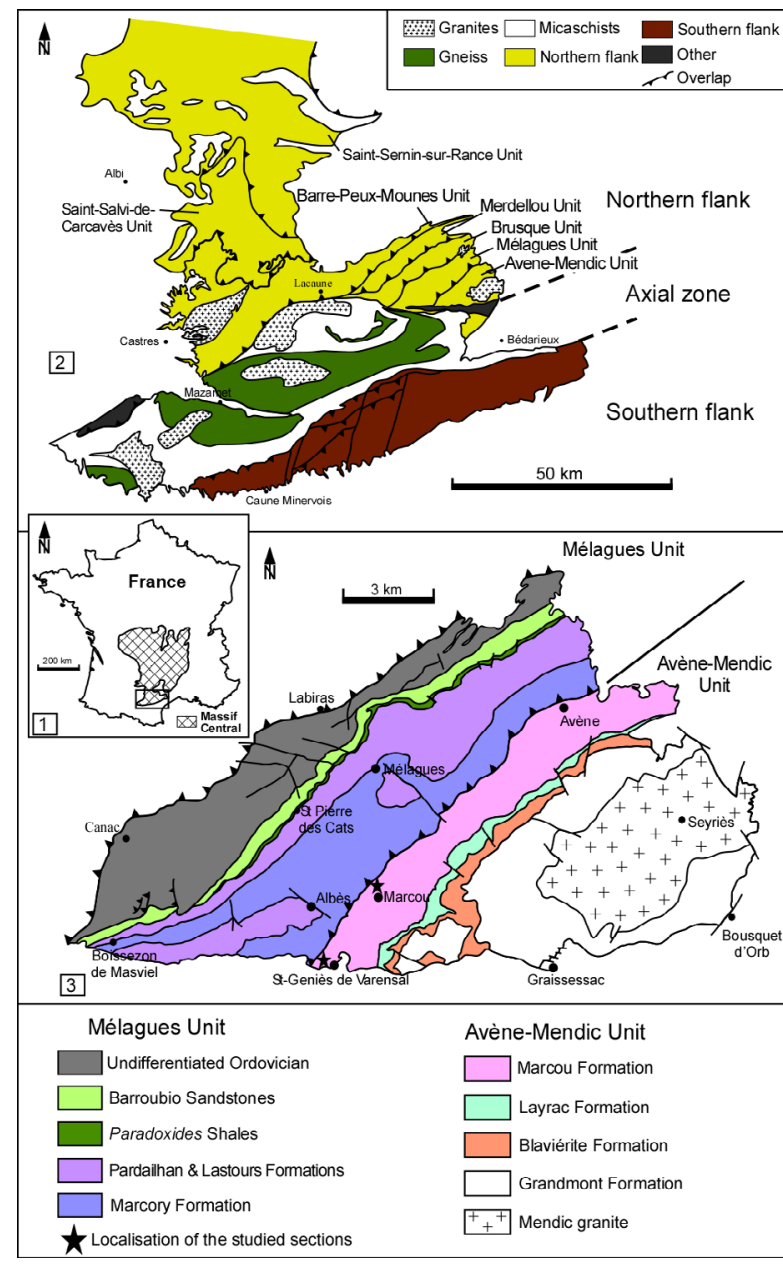

FIGURE 1. Geological settings of the Montagne Noire (after Clausen and Álvaro, 2007). 1- Location of the Massif Central and the Montagne Noire in France. 2Structural sketch of the Montagne Noire. 3- Geological sketch of the Northern flank Avène-Mendic and Mélagues Units with location of the studied sections.

aultia Limestone, reported by Cobbold (1935) and Kerber (1988), crops out in the Avène-Mendic parautochthon.

Strata of the parautochthon consists of a volcanosedimentary succession (Figure 3 ). The lowermost strata consist of a shale-dominated succession, $500-700 \mathrm{~m}$ thick, traditionally related to "Schistes X" Formation of the Axial Zone, and recently distinguished as the Grandmont Formation by Álvaro et al. (in press). The Grandmont Formation consists of finely bedded arkose and shale. A distinct episode of volcanic activity is recorded by the overlying Blaviérite Formation (sensu Álvaro et al., in press), up to $200 \mathrm{~m}$ thick and represented by rhyolitic tuffs locally interrupted by rhyolitic breccias (Bergeron, 1889; Rolet, 1973). The blaviérite is overlain by the Layrac Formation, a volcanosedi- mentary unit, up to $300 \mathrm{~m}$ thick, composed of litharenitic conglomerates and sandstone and variegated shale containing reworked elements from the underlying blaviérite. The upper part of the succession in the Avène-Mendic unit is marked by the progressive onset of carbonate productivity. This carbonate-dominated succession, named Marcou Formation by Álvaro et al. (in press), can be subdivided into distinct members: (1) a lower member composed of dolostone/shale alternations, 200-300 m thick; (2) a monotonous dolostone package, up to $900 \mathrm{~m}$ thick and, (3) the Heraultia Limestone or Member, $60 \mathrm{~m}$ thick, composed of thin- to medium-bedded bioclastic limestone rich in phosphatic hardgrounds, hardgroundderived clasts and phosphatic skeletons. The Heraultia Limestone can be properly studied in three areas: the vicinity of Saint-Geniès-de-Varensal village and the Marcou and Thalis summits, which are cut by the D52 road. As documented by Clausen and Álvaro (2007) and Álvaro and Clausen (2010), the Heraultia Limestone contains a succession of repeated cycles of sedimentation, phosphate concentration and reworking, which took place along a platform transect between a stable inner shelf and an unstable slope-to-basin seafloor. The phosphatisation was most probably microbially mediated, which is well preserved in the studied shelly phosphorites.

The Heraultia Limestone has yielded the only fossil record of the Avène-Mendic parautochthon, although its age has been traditionally suggested by lithostratigraphic correlation with neighbouring nappes from the northern and southern Montagne Noire (Rolet, 1973; Bogdanoff et al., 1984; Kerber, 1988; Clausen and Álvaro, 2007; Álvaro and Clausen, 2010). Kerber (1988) suggested an Atdabanian/Botoman (Cambrian Stages 3 and 4) age for the Heraultia Limestone: evidences supporting this age are mainly based on the traditional lithostratigraphic correlation of the Marcou Formation with the lower Cambrian "Archæocyathus Limestone" or "masse carbonatée" of the Montagne Noire (Lastours and Série Noire formations sensu Álvaro et al., 1998 and Álvaro, in press; Figure 3). In the neighbouring Brusque Unit, the presence of trilobites and archaeocyaths (Dictyocyathus sp., Graphocyphia cf. lata, Graphocyphia sp. described by Debrenne and Courjault-Radé, 1986), allowed its assignment to the Adtabanian/Botoman. However, the Avène-Mendic parautochthon is devoid of archaeocyaths (although Michel-Levy, 1932 reported the presence of archaeocyathids at the base of the Marcou Formation at Col du Layrac, 


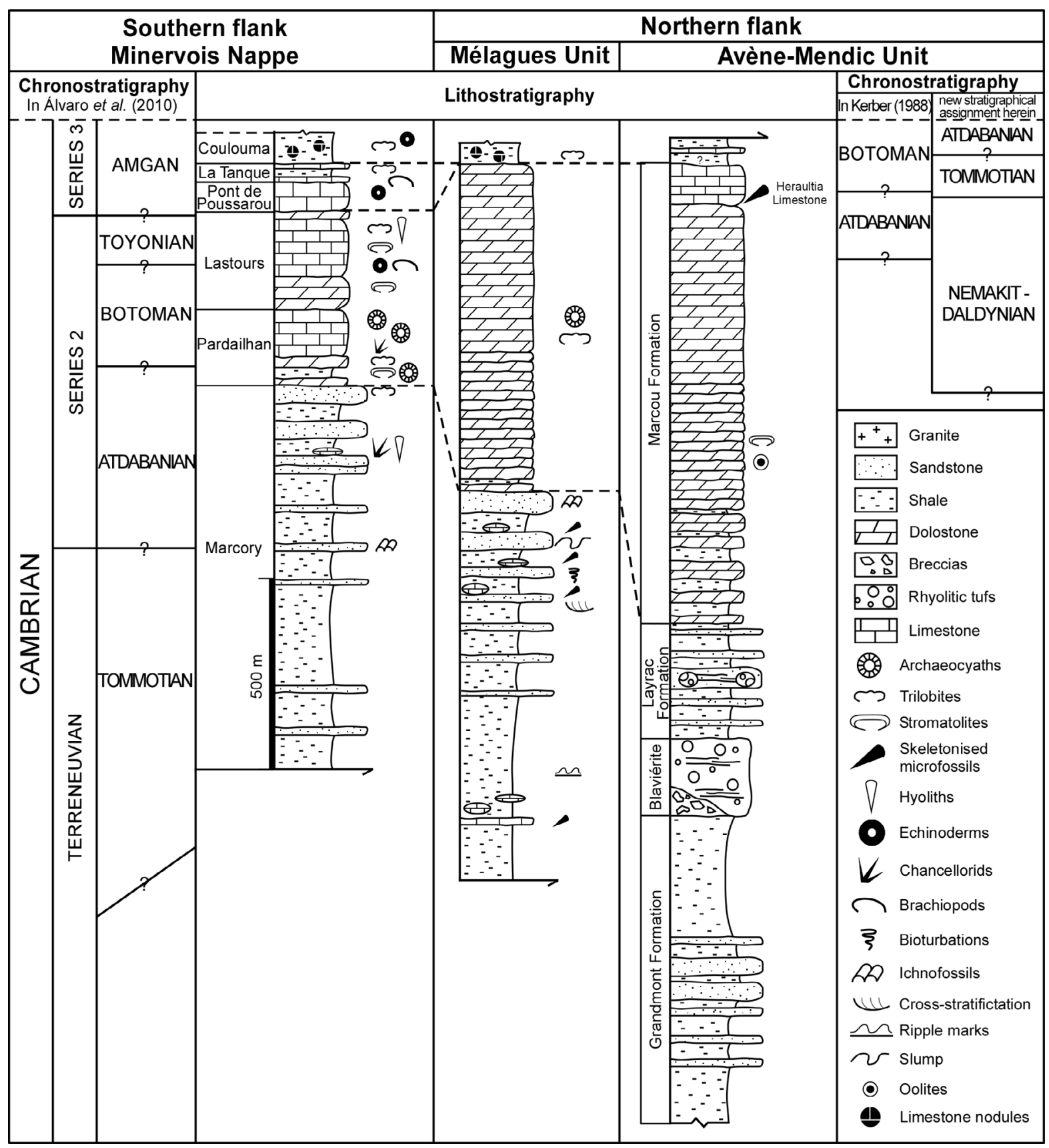

FIGURE 2. Attempt of lithological correlation between northern (Clausen and Álvaro, 2007) and southern flank of the Montagne Noire (Álvaro et al. 2010) and chronostratigraphic divisions of the southern flank (Álvaro et al. 2010) and of the northern flank (Kerber, 1988; Clausen and Álvaro, 2007).

Rolet (1973) refers to a possible thin section figuring the putative specimen, which is not available anymore and the relative outcrop has never yielded any additional specimens) and trilobites. The top of the Marcou Formation is moreover overthrust by the Mélagues unit, and a biostratigraphic re-assessment is documented below based on new sampled material.

\section{MATERIAL AND METHODS}

The fauna from the Heraultia Limestone, first described by Cobbold (1935) and later by Kerber (1988), have been analysed through a new sampling of four sections in some localities already studied by Kerber (1988). Two sections $\left(\mathrm{K}_{2}\right.$ and $\left.\mathrm{K}_{3}\right)$ are located in the vicinity of Marcou Village, northwards to Saint Geniès-de-Varensal (Figure 1.3) 


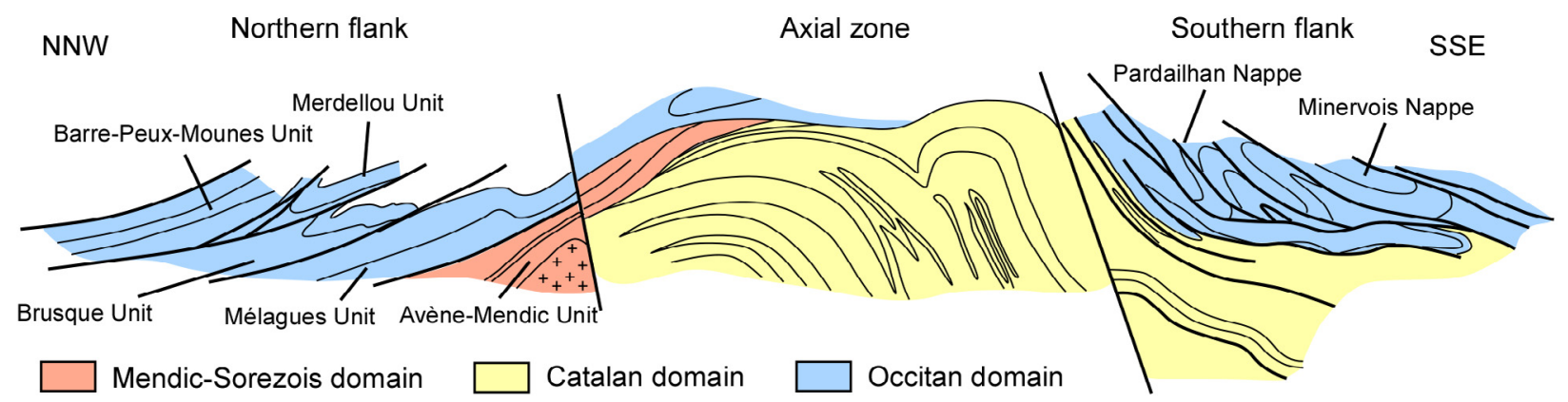

FIGURE 3. Cross-section of the Montagne Noire detailling its general structural pattern. The Catalan domain corresponds to the Gondwana precambrian basement cropping in the Axial Zone. The Para-autochtonous Units (mendicSorezois domain) thrusts above the Axial Zone. Finally, the Occitan domaine comprises paleozoic sediments supposed to have deposited at the margin of the Catalan craton (Demange, 2001).

and most probably correspond to Kerber's (1988) sections II-III. The other two sections $\left(\mathrm{K}_{4}\right.$ and $\left.\mathrm{K}_{5}\right)$ are located on the northern and southern banks of the Buissou River, upstream from Saint Geniès-deVarensal (Figure 1.3), and are situated nearby sections I and S of Kerber (1988). The exact position of Kerber's sections is difficult to estimate as dense vegetation and/or weathering have affected outcrops. Section $\mathrm{K} 5$ is the longest and most complete. The Heraultia Limestone was sampled about each metre from each section. The samples were treated with c. $10 \%$ acetic acid to release phosphatised specimens from the carbonate matrix. Specimens were picked up from residues under stereomicroscope and observed and pictured with Scanning Electron Microscope Zeiss Supra 40 VP at the Freie Universität Berlin and a FEI Quanta 200 at the University of Lille 1.

\section{SYSTEMATIC PALAEONTOLOGY}

\section{(DEVAERE, CLAUSEN, and STEINER)}

The global stratigraphic repartition of the species identified in the present material is based on the Siberian Chart. A correlation with other regional stratigraphic scales and proposed IUGS Units is given in Appendix. The described and figured material is housed in the collections of the University of Lille 1 (USTL: Université des Sciences et Technologies de Lille). The synonymy list for most of the genera, with a minor edition, is taken from Parkhaev and Demidenko (2010).

Phylum MOLLUSCA Cuvier, 1797

Class HELCIONELLOIDA Peel, 1991

Emended diagnosis. Generally bilaterally symmetrical univalves in which the calcareous shell is usually coiled through up to several whorls; the whorls may be in contact or open coiled and are often laterally compressed. The aperture is oval, without re-entrant but the subapical surface may develop a median sinus which is occasionally deep and slit-like or even trematose, with a single perforation at the end of an elongate tube termed the snorkel. In some forms, the lateral areas of the aperture may become prosocyrt, extended into weak lateral fields and producing broad emarginations in both the supraapical and subapical surfaces astride the plane of symmetry. Ornamentation may include both comarginal and spiral elements; prominent comarginal rugae are common (emended after Peel, 1991).

Discussion. The taxonomic assignment of following genera to the class Helcionelloida Peel, 1991 presented herein is consistent with Peel (1991) and Gubanov and Peel's (2000) morpho-functionnal interpretations (endogastric organisation $=$ the shell apex is located posteriorly whereas the shell expands anteriorly). Unfortunately, the new material does not provide further evidence of the species to be untorted mollusc, therefore, belonging to the Helcionelloida instead of the Gastropoda (as suggested by a number of authors, for the review see table 3.1 in Parkhaev, 2008). In addition, the position of the mantle cavity together with the direction of the water current suggested by Peel (1991) and Parkhev (2000, 2001, 2002) cannot be confirmed through the present material.

Order HELCIONELLIDA Geyer, 1994

Family HELCIONELLIDAE Wenz, 1938

Genus OELANDIELLA Vostokova, 1962

1962 Oelandiella Vostokova, 1962, p. 52.

1969 Latouchella; Rozanov et al. p. 142.

1976 Latouchella; Runnegar and Jell, p. 126.

1979 Archaeospira Yu, 1979, p. 255. 
1979 Yangtzespira Yu, 1979, p. 255.

1980 Yangtzespira; Jiang, p. 120.

1980 Yunnanospira Jiang, 1980a, p. 120.

1981 Cambroconus Yu, 1981, p. 553-556.

1981 Huanglingella Chen, Chen and Zhang in Chen et al., 1981, p. 37.

1981 Hubeispira Yu, 1981, p. 554-556.

1983 Latouchella; Yu, p. 291.

1983 Reticulatoconus Yu, 1983, p. 291.

1984 Gibbaspira He, 1984, p. 27.

1984 Uncinaspira He, 1984, p. 24.

1986 Latouchella; Geyer, p. 77.

1987 Archaeospira; Yu, p. 193.

1987 Cambroconus; Yu, p. 176.

1987 Hubeispira; Yu, p. 204-206.

1987 Latouchella; Yu, p. 181.

1987 Yangtzespira; Yu, p. 209.

1988 Latouchella; Peel, p. 152.

1989 Archaeospira; Qian and Bengtson, p. 111.

1989 Latouchella; Missarzhevsky, p. 177.

1990 Pseudoyangtzespira Bokova, 1990, p. 123.

1994 Latouchella; Geyer, p. 77.

1998 Latouchella; Vassiljeva, p. 80.

1999 Oelandiella; Gubanov and Peel, p. 217.

2003 Archaeospira ornata; Feng and Sun, p. 27.

2010 Latouchella; Parkhaev and Demidenko, p. 1054-1058.

Type species. Oelandiella korobkovi Vostokova, 1962, Tommotian (Nochoroicyathus sunnaginicus Zone), Kotuikan River, East Krasnoyarsk Region, Siberian Platform, Russian Federation.

Emended diagnosis. Small, univalve mollusc with tightly coiled, rapidly expanding shell of half a whorl to several, with prominent transverse ribs which cross the dorsum (emended after Gubanov and Peel, 1999).

Remarks. Following Gubanov and Peel (1999), the genus Latouchella Cobbold, 1921 is characterised by the presence of a smooth dorsum and is therefore restricted to the type species $L$. costata Cobbold, 1921 and to L. ostenfeldense Skovsted, 2004. All other species that have been assigned to Latouchella, which clearly exhibit ribs crossing the dorsum, are considered herein to belong to the genus Oelandiella Vostokova, 1962.
Following Gubanov and Peel (1999, 2000), the genus Archaeospira Yu, 1979 (senior synonym of Yangtzespira Yu, 1979; Qian and Bengtson, 1989 ) is considered herein as a junior synonym of Oelandiella Vostokova, 1962. Qian and Bengtson (1989) characterised Archaeospira by its asymmetrical coiling, absent in Oelandiella (and Latouchella). However, Guvanov and Peel (1999, text-figure A,F,I) pointed out that, in the holotype of Oelandiella korobkovi, "the shell becomes slightly asymmetrical, as clearly seen in dorsal view." The specimens from the Heraultia Limestone confirm this observation. Therefore, Archaeospira and Oelandiella are herein emphasized under the genus Oelandiella.

Oelandiella korobkovi Vostokova, 1962

\section{Figure 4.1-24}

1962 Oelandiella korobkovi Vostokova, 1962, p. 52, pl. 1, figs. 1-4.

1962 Oelandiella sibirica Vostokova, 1962, p. 52, pl. 1, figs. 5-7.

1969 Latouchella korobkovi (Vostokova); Rozanov et al., p. 142, pl. 3, figs. 4a, 7, 11, 12, 19, 20, pl. 4, fig. 17.

1979 Anabarella emeiensis Yu in Lu, 1979, pl. 3, fig. 15, non figs. 12-14 [recte Igorella emeiensis].

1979 Archaeospira imbricata Yu, 1979, p. 255, pl. 3, figs. 24-27.

1979 Archaeospira ornata Yu, 1979, p. 255, pl. 4, figs. 14-17.

1979 Latouchella cf. memorabilis Missarzhevsky in Rozanov; Yu, 1979, p. 252, pl. III fig. 20.

1979 Latouchella raricostata Yu in Lu, 1979, pl. 3, figs. 4-9.

1979 Yangtzespira exima Yu, 1979, p. 255, pl. 4, figs. 18-21.

1980 Archaeospira ornata; Yin et al., p. 156, pl. 13, figs. 9, 10.

1980 Archaeospira ornata; Zhao et al., p. 51.

1980 Archaeospira sp.; Yin et al., p. 156, pl. 13, figs. 17, 18.

1980 Bemella jacutica (Missarzhevsky in Rozanov and Missarzhevsky); Yin et al., p. 156, pl. 13 , figs. 4,5 .

1980a Igorella cf. ungulata; Jiang, pl. 3, fig. 8.

1980a Latouchella korobkovi; Jiang, p. 122, pl. 3, figs. $1 \mathrm{a}-1 \mathrm{c}$. 


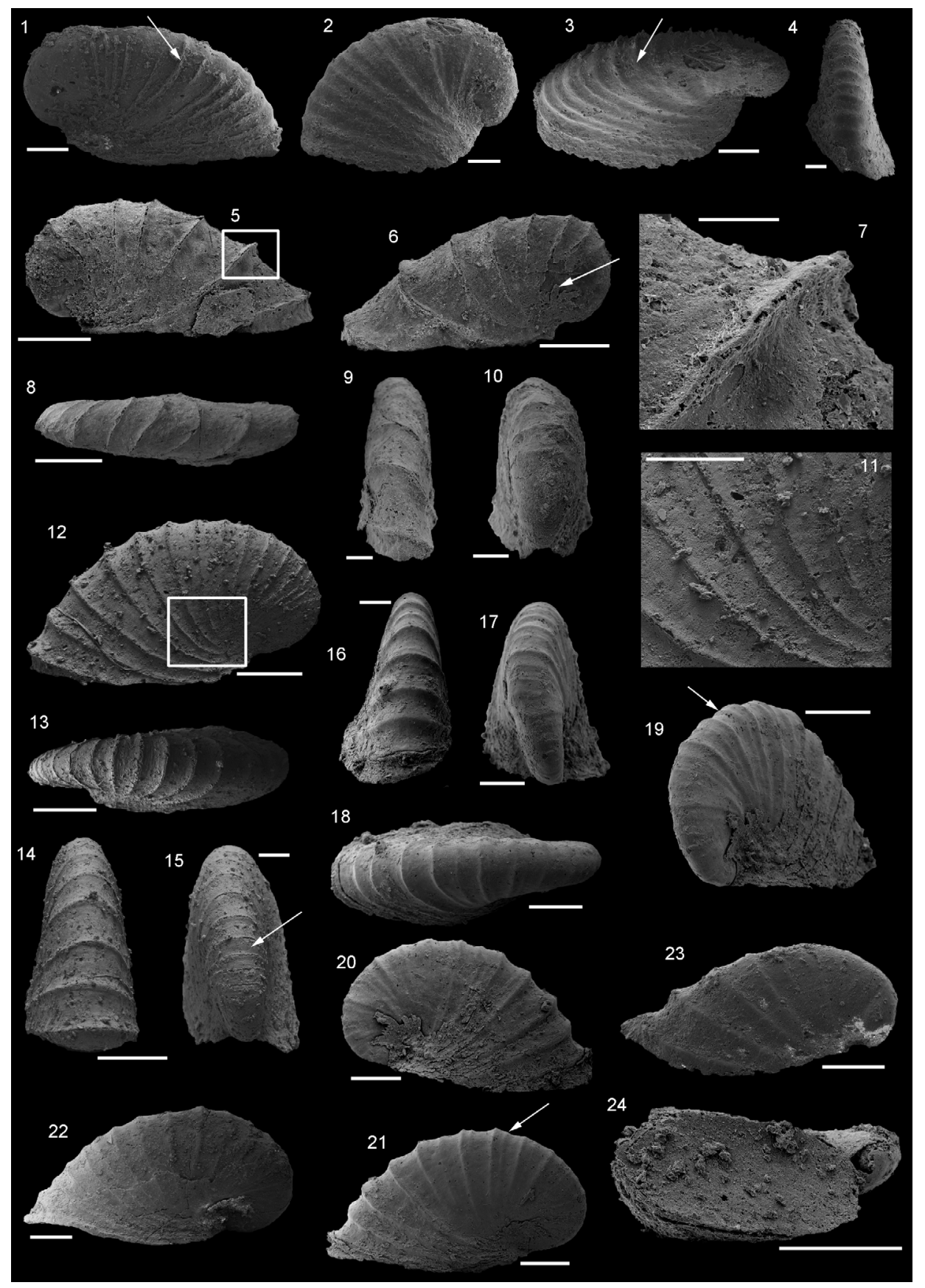

FIGURE 4. Oelandiella korobkovi, Vostokova 1962. 1-4 USTL1235/1: 1. Right lateral view, arrow shows external coating of the shell on a comarginal rib; 2. Left lateral view; 3. Upper lateral view, arrow shows intermediate rib; 4. Anterior view showing ribs crossing the dorsum. 5-10 USTL1259/5: 5. Right lateral view with square showing location of 7; 6 . Left lateral view, arrow shows the external coating; 7. Detail of sharp comarginal rib; 8. Upper view; 9. Anterior view showing ribs crossing the dorsum; 10. Posterior view showing planispiral complete whorl with smooth apex. 11-15 USTL1241/9: 11. Detail of co-marginal ribs slightly tapering and fading close to the umbilicum; 12 . Left lateral view; 13. Upper view; 14. Anterior view with ribs crossing the dorsum; 15. Posterior view, arrow shows external coating of the shell. 16-21 USTL1257/3: 16, 17. Anterior and posterior views respectively; 18. Upper view; 19. Posterior-lateral view, arrow shows intermediate rib; 20 . Right lateral view of the internal mold with external coating; 21. Left lateral view, arrow shows intermediate rib. 22. USTL1258/10, left lateral view showing sinuous apertural margin. 23. USTL1255/ 13 , left lateral view showing incomplete whorl and uplifted apex from the apertural plan. 24. USTL1246/5, apertural view showing aperture elongated along the antero-posterior axis. Scale bars equal: 7, $100 \mu \mathrm{m} ; 4,9,10,15,200 \mu \mathrm{m} ; 1$ $3,11,16,17,300 \mu \mathrm{m} ; 5,6,8,12,13,14,18-24,500 \mu \mathrm{m}$. 
1989 Latouchella korobkovi; Missarzhevsky, pl. 6, figs. 2, 3, 5a.

1980 Latouchella korobkovi; Yin et al., p. 156, pl. 13, fig. 8 (cf. korobkova [sic]).

1980 Latouchella songlingpoensis Chen and Zhang, 1980, p. 195, pl. 1, figs. 39, 46.

1980 Maidipingoconus maidipingensis (Yu); Chen, p. 58, pl. 1, fig. 14.

1980 Maidipingoconus maidipingensis (Yu); Yin et al., p. 155, pl. 14, figs. 1-3, 10, 11.

1980a Yangtzespira regularis Jiang, 1980a: 120, pl. 3, fig. 2.

1980 Yangtzespira regularis; Luo et al., p. 99, pl. 1, fig. 24.

1980a Yunnanospira multiribis Jiang, 1980a, p. 120, pl. 3, fig. 3.

1980 Yunnanospira multiribis; Luo et al., pl. 1, fig. 27.

1981 Huanglingella polycostata Chen, Chen and Zhang in Chen et al., 1981, p.37, pl. 1, fig. 19.

1981 Hubeispira nitida Yu, 1981, p.534, pl. I, figs. 14-19.

1981 Yangtzespira xindianensis Yu, 1981, p. 553, pl. 1, figs. 11-13.

1982 Igorella ungulata Missarzhevsky in Rozanov et al.; Luo et al., p. 191, pl. 20, fig. 4.

1982 Latouchella korobkovi; Luo et al., p. 190, pl. 19, figs. 8, 9.

1982 Latouchella korobkovi; Voronin et al., p. 43, pl. 1, fig. 1.

1982 Latouchella minuta Zhegallo in Voronin et al., 1982, p. 44, pl. 1, fig. 4.

1982 Latouchella sibirica (Vostokova); Voronin et al., p. 44, pl. 1, fig. 2.

1982 Yangtzespira exima; Luo et al., p. 189, pl. 19, fig. 14.

1982 Yangtzespira regularis; $\mathrm{He}$ and Yang, 1982, pl. 3, figs. 10-12.

1982 Yangtzespira regularis; Luo et al., p. 189, pl. 19, fig. 10;

1982 Yunnanospira multiribis; Luo et al., p. 189, pl. 19, fig. 13.

1983 Latouchella korobkovi; Zhegallo, p. 99, pl. 33, fig. 9.
1984 Archaeospira ornata; Xing et al., pl. 5, fig. 13.

1984 Archaeospira ornata; Yu, p. 30, pl. 2, fig. 12.

1984 Archaeospira sp.; Chen, p. 58, pl. 1, fig. 14.

1984 Gibbaspira acutumbonalis He, 1984, p. 27, pl. 2, figs. 1-4.

1984 Uncinaspira pristina He, 1984, p. 25, pl. 2, figs. 16, 17.

1984 Uncinaspira ruidocostata He, 1984, p. 25, pl. 2, figs. 10-13.

1984 Yangtzespira exima; Luo et al., pl. 10, fig. 1.

1984 Yangtzespira exima; Yu, p. 28, pl. 2, figs. 10, 11.

1984 Yangtzespira multicostata He in Xing et al., 1984, pl. 13, figs. 8, 9.

1984 Yangtzespira regularis; Xing et al., pl. 10, fig. 13.

1984 Yunnanospira multiribis; Luo et al., pl. 10, fig. 2.

1984 Yunnanospira multiribis; Xing et al., pl. 10, fig. 20.

1987b Archaeospira imbricata; Yu, p. 196, pl. 43, figs. $7-10$, pl. 46 , figs. $4-6$, pl. 48 , figs. 2 , 3, 5-8; pl. 49, figs. 6-9; pl. 54, figs. 4-6.

1987b Archaeospira ornata; Yu, p. 194, text-figs. 29a-29c, 57, pl. 43, figs. 4-6, pl. 48, figs. $1,4,9$, pl. 49 , figs. $1-5,10-12$, pl. 50 , figs. $1-9$, pl. 51 , figs. $1-7$, pl. 53 , figs. 5-7, pl. 54, figs. 1-3, pl. 58, fig. 9.

1987a Archaeospira? sp.; Yu, pl. 44, figs. 1-2; pl. 45, figs. 1-6.

1987b Archaeospira sp.;Yu, p. 198, pl. 40, figs. 1, 2, 5, 6, 10, 11; pl. 46, figs. 9-11; pl. 47, figs. 8,9 ; pl. 53. figs. 8 , 9 ; pl. 54 , figs. $7-$ 12.

1987b Hubeispira nitida; Yu, p. 206, pl. 55, figs. 1-7; pl. 56, figs. 5-8.

1987b Latouchella cf. korobkovi; Yu, p. 185, pl. 39 , figs. $1-6$; pl. 43 , figs. $1-3$, pl. 46 , figs. $1-3,7,8$, pl. 47 , figs. 3-7.

1987 Latouchella vetula Valkov, 1987, pl.1, fig. 1.

1987a Yangtzespira exima; Yu, pl. 5, figs. 11-13, pl. 4, figs. 6-8. 
1987b Yangtzespira exima; Yu, p. 211, text-figs. 22, 29d, 29e, 64, pl. 47, figs. 1, 2; pl. 53, figs. $1-4$; pl. 57 , figs. $1-8$; pl. 58 , figs. $1-8$, pl. 59 , figs. $1-7$.

1988 Latouchella angusta (Cobbold); Kerber, p. 171, pl. 7, figs. 7-12, 14-17.

1988 Yangtzespira exima; Yu, figs. 8-10.

1989 Archaeospira cf. ornata; Qian and Bengtson, p. 116, fig. 74 .

1989 Archaeospira cf. songlingpoensis: Qian and Bengtson, p. 116, text-fig. 75.

1989 Archaeospira ornata; Qian and Bengtson, p. 112, text-figs. $72,73$.

1989 Archaeospira sp.; Khomentovsky and Karlova, p. 49, pl. 4, figs. 1, 2.

1989 Latouchella korobkovi; Hamdi et al., fig. $3 a$.

1989 Latouchella korobkovi; Khomentovsky and Karlova, p. 48, pl. 3, fig. 6.

1989 Latouchella maidipingensis (Yu); Hamdi, pl. 11, figs. 4-7, non fig. 10 , non pl. 16, figs. 7-10 [recte Igorella maidipingensis].

1989 Latouchella maidipingensis; Khomentovsky and Karlova, p. 49, pl. 3, fig. 8.

1989 Yangtzespira regularis; Khomentovsky and Karlova, p. 50, pl. 3, fig. 9.

1990 Archaeospira ornata; Pelman et al., pl. 1, fig. 10.

1990 Archaeospira ornata; Yu, pl. 8, figs. 4-11.

1990 Igorella ungulata; Pelman et al., pl. 1, fig. 13.

1990 Latouchella korobkovi; Pelman et al., pl. 1, figs. 20, 22, 27.

1990 Yangtzespira exima; Yu, p. 146, text-fig. 5, pl. 9, figs. 1-10.

1991 Latouchella korobkovi; Dzik 1991: figs. 7e, $7 f$.

1994 Latouchella korobkovi; Luo et al., pl. 2, fig. 2.

1994 Yangtzespira regularis; Luo et al., pl. 2, fig. 1.

1995 Archaeospira ornata; Hamdi, pl. 12, figs. 6, 8, 10.

1995 Archaeospira regularis (Jiang): Hamdi, pl. 15, figs. $1,2$.
1995 Latouchella korobkovi; Hamdi, pl. 11, figs. 1, 2, 8, 9, 12 (cf. korobkovi); pl. 12, figs. 3, 7, 9, 11, 12; pl. 16, figs. 11, 12.

1996 Latouchella korobkovi; Esakova and Zhegallo, p. 176, pl. 21, fig. 6 .

1996 Latouchella magnifica Zhegallo in Esakova and Zhegallo, 1996, p. 179, pl. 21, fig. 7.

1996 Latouchella minuta; Esakova and Zhegallo, p. 179, pl. 21, fig. 4.

1996 Latouchella numerosa Zhegallo in Esakova and Zhegallo, 1996, p. 177, pl. 21, fig. 5 .

1996 Latouchella sibirica; Esakova and Zhegallo, p. 176, pl. 21, fig. 3.

1998 Latouchella korobkovi; Vassiljeva, p. 80, pl. 6, figs. 21, 23.

1998 Latouchella sibirica; Vassiljeva, p. 80, pl. 6, fig. 24.

1999 Oelandiella korobkovi; Gubanov and Peel, p. 217 , text-figs. 4, 5, 6A-6D, 7.

1999 Oelandiella sibirica; Gubanov and Peel, p. 217, text-figs. 6E-6F.

2000 Latouchella korobkovi; Gubanov and Peel, figs. $2 a, 2 b$, non fig. 2c, 2d [recte Igorella maidipingensis], fig. 3.

2003 Archaeospira ornata; Feng and Sun, p. 27, text-fig. 6.

2003 Oelandiella korobkovi; Demidenko et al., figs. 3a-3c.

2004 Oelandiella korobkovi; Parkhaev, pl. 2, fig. 1.

2005 Latouchella korobkovi; Parkhaev, pl. 4, figs. 2, 3, 5-8.

2006 Latouchella korobkovi; Demidenko and Parkhaev, text-figs. 5d, 5e.

2008 Latouchella korobkovi; Parkhaev, text-figs. 3.14C, 3.14D.

2010 Latouchella korobkovi; Parkhaev and Demidenko, p. 1054-1058, pl. 72, figs. 116.

Material. About 100 complete to partly broken phosphatic internal molds and about 10 internal molds preserved with an external phosphatic coating (figured specimens are USTL1235/1, USTL1241/9, USTL1246/5, USTL1255/13, USTL1257/3, USTL1258/10, and USTL1259/5).

Distribution. Section $\mathrm{K} 2$, samples $\mathrm{K} 2 / 3 \mathrm{~b}, \mathrm{~K} 2 /_{4 \mathrm{~b}}$, $\mathrm{K} 2 /{ }_{6}, \mathrm{~K} 2 /{ }_{120}, \mathrm{~K} 2 /{ }_{14}$, and $\mathrm{K} 2 /{ }_{16}$; section $\mathrm{K} 3$, samples 
$\mathrm{K} 3 \mathrm{~T} / 2 \mathrm{c}, \mathrm{K} 3 \mathrm{~T} / 2 \mathrm{e}, \mathrm{K} 3 \mathrm{~T} / 3 \mathrm{a}, \mathrm{K} 3 \mathrm{~T} / 4 \mathrm{a}, \mathrm{K} 3 \mathrm{~B} / 2 \mathrm{a}$, and $\mathrm{K} 3 \mathrm{~B} / 6$; section $\mathrm{K} 4$, sample $\mathrm{K} 4 \mathrm{I}_{4 \mathrm{a}}$; section $\mathrm{K} 5$, samples $\mathrm{K} 5$ / 2, $\mathrm{K} 5 /_{3}, \mathrm{~K} 5 \mathrm{~b} / 2, \mathrm{~K} 5 \mathrm{~b} / 3, \mathrm{~K} 5 \mathrm{~b} / 4, \mathrm{~K} 5 \mathrm{~b} / 8, \mathrm{~K} 5 /_{12}, \mathrm{~K} 5 /_{32}$, and $\mathrm{K} 5 / 39$.

Description. These laterally compressed univalve organisms, preserved as internal molds and eventually characterised by an external shell coating, are more or less tightly coiled into a half (Figure 4.23 ) to a complete whorl (Figure 4.1-22). When loosely coiled, an opened umbilicus is observed (Figure 4.23). Most specimens are planispiraly organised (Figure 4.4, 4.8-10, 4.14-15). However, an asymmetry is occassionally observed when the aperture is displaced laterally toward one preferential side (Figure 4.16-18, 4.24). The conch rapidly expands, becoming large and flared close to the aperture (Figure 4.4, 4.17). Aperture is elongate along the antero-posterior axis (oval; Figure 4.24) and sinuous in outline (Figure 4.22), although generally slightly broken (Figure $4.56,4.12$ ). The plan of the apertural margin is perpendicular to the whorl expansion axis. The lateral fields are straight in the dorsal area and become curved and concave toward the apertural margin (Figure 4.4, 4.14-17). They are completely straight in flattened specimens (e.g., Figure 4.9-10). The apex is smooth (Figure 4.15, 4.17, 4.19). In tightly coiled conches, the dorsal side of the apex is in contact with the subapical area of the last whorl (Figure 4.19-22). The apex lies in the apertural plane (Figure 4.1922 ) or is occassionally slightly shifted off from it (Figure 4.1-2, 4.5-6, 4.23). External surface of internal molds and shell-coatings display comarginal ribs which always cross the dorsum (Figure 4.4, 4.9, 4.14, 4.16) and slightly taper and fade close to the umbilicus (Figure 4.11, 4.21-22). They greatly vary in number and spacing (compare Figure 4.1-4 and Figure 4.5-10). Specimens densely ribbed exhibit intermediate ribs, flanked by two primary ribs, which disappear rapidly toward the umbilicus (arrows in Figure 4.3, 4.19, 4.21). When present, intermediate ribs vary in number and repartition along the coiled shell. The ribs are roughly triangular in transverse section. They are rounded (Figure 4.1-4, 4.16-23) to sharp (Figure 4.5-15) most probably linked to preservation. They are straight in the dorsal region but tend to curve toward the umbilicus, with its concavity oriented anteriorly (Figure 4.11). External coatings of the shell (arrows in Figure 4.1, 4.6, 4.15) exhibit similar ornamentation as internal molds, arguing that this ornamentation represents folds of the thin shell.

Remarks. The specimens studied herein are slightly-to-highly deformed (Figures 4.8-4.10); therefore, the degree of lateral compression is variably expressed, depending on the axis of compression they suffered while randomly oriented in the bioaccumulation. Effect of deformation on the variable outer-shape was most probably important although an original intraspecific variability cannot be rejected. Comarginal ribs are also variously preserved. However, the presence or absence of intercalated secondary ribs in the described assemblage cannot be interpreted as a preservation bias. Ornamentation density, repartition, and number of secondary ribs along a shell vary independently from the specimen size. It is therefore interpreted herein as intraspecific variability from O. korobkovi holotype, on which secondary ribs are absent, to $O$. songlingpoensis (Chen and Zhang, 1980), with strict alternation of primary and secondary ribs.

Comparisons. Parkhaev and Demidenko (2010) include 10 species into the genus Latouchella which are considered herein as Oelandiella species. Among these, Oelandiella angusta (Cobbold, 1935) and O. korobkovi may be synonym as they only differ in the expression and number of ribs (in the same way as $O$. songlingpoensis). However, specimens of $O$. angusta were only drawn by Cobbold (1935) so this material should be restudied before to conclude on synonymy between $O$. angusta and O. korobkovi. Oelandiella selindeica (Bokova, 1990) differs from O. korobkovi in its tight dextral coiling whereas the coiling of $O$. korobkovi is either dextral or sinistral (Gubanov and Peel 1999, and observations herein). Oelandiella vetula (Valkov, 1987) cannot be objectively differentiated from O. korobkovi. However, Oelandiella memorabilis (Missarzhevsky in Rozanov et al., 1969) clearly differs from $\mathrm{O}$. korobkovi in the presence of an antispiral sinus on the ribs. As only the holotype exhibits such a sinus; all the other specimens of $O$. memorabilis lacking this structure are emphasized with O. korobkovi. Oelandiella nazarovi (Zhegallo in Esakova and Zhegallo, 1996) has a smooth internal mold and regularly ribbed external mold. The ornamentation of $O$. nazarovi therefore corresponds to thickening of the shell, which clearly differs from $O$. korobkovi. Such a shell organisation (internal surface smooth and outer surface ornamented) is not diagnostic of the genus Oelandiella. Therefore, the generic assignment of Oelandiella nazarovi should be reassessed.

Other occurences. Upper Shale Member, Soltanieh Formation, upper Nemakit-Daldynian to Tommotian (Paragloborilus subglobosusSiphogonuchites triangularis Zone), Valiabad, 
Elburz Mountains, Iran (Hamdi et al., 1989); Bayan-Gol Formation, Tommotian (Anabarella plana Zone and Watsonella crosbyi Zone), Salaany-Gol, Orolgay-Gol, Bayan-Gol, Tayshir and Hevte Tsakhir Nuruu, Western Mongolia (Voronin et al., 1982; Esakova and Zhegallo, 1996).

Siberia: Kessyusa Formation, Nemakit-Daldynian to Tommotian (Anabarella plana Zone and Watsonella crosbyi Zone) at various Olenek Uplift sections (Valkov, 1987; Khomenthovsky and Karlova, 1993; Knoll et al., 1995); Member IV of the UstYudoma Formation and Sunnagin Member of the Pestrotsvet Formation, Nemakit-Daldynian to Tommotian (Purella antiqua Zone to Watsonella crosbyi Zone) at Dzhanda (Khomentovsky and Karlova, 1989; 1993); Sunnagin Member, Pestrotsvet Formation, Tommotian (Watsonella crosbyi Zone) at the Gonam River, Mount 1291.1 (Khomentovsky and Karlova, 1993); Pestrotsvet Formation, Tommotian (Watsonella crosbyi to Lapworthella bella zones), Nemnekey section between the Gonam and Nemnekey rivers (Khomentovsky and Karlova, 1993), Aldan River, middle reaches of the Lena River, Fomich River and Eriechka River near Nemakit-Daldyn River mouth, northwestern flanks of the Anabar Uplift (Rozanov et al., 1969; Kruse et al., 1995) and Selinde River near Mar-Kyuyel (Missarzhevsky, 1989; Bokova, 1990; Khomenthovsky and Karlova, 1993); Medvezh'ya Formation, Tommotian (Watsonella crosbyi to Lapworthella bella zones), Kotuj River, northwestern flanks of the Anabar Uplift (Vostokova, 1962; Rozanov et al., 1969; Missarzhevsky, 1989; Gubanov and Peel, 1999; Kouchinsky, 1999; Parkhaev, 2004); Yudoman Formation, Tommotian (Lapworthella tortuosa subzone of the Dokidocyathus regularis Zone), 7 $\mathrm{km}$ west of Ugino Village (Rozanov et al., 1969).

China: Huangshandong Member, Tongying Formation, Nemakit-Daldynian to Tommotian? (Paragloborilus subglobosus-Purella squamulosa Zone to Watsonella crosbyi Zone?), Huangshandong, Yichang County, Hubei Province (Yu, 1979; 1987b); Maidiping Formation, Nemakit-Daldynian to Tommotian (Paragloborilus subglobosus-Purella squamulosa Zone to Watsonella crosbyi Zone), Gaoqiao and Maidiping, Emei County, Sichuan province (Yin et al., 1980; Xing et al., 1984; Yu, 1987b; Steiner et al., 2007); Zhongyicun Member and Dahai Member, Zhujiaqing Formation, Nemakit-Daldynian to Tommotian (Paragloborilus subglobosus-Purella squamulosa Zone to Watsonella crosbyi Zone), Wnagjiawan, Jinning County (Jiang, 1980a; Yu, 1987b; Qian and Bengtson, 1989), Dadiyakou, Chengjiang County (Yu, 1987b), Nizeqing section (Qian et al., 1996), Dahai (Luo et al., 1982; Yu, 1987b; Xing et al., 1984; Feng and Sun, 2003) and Yulu (Feng and Sun, 2003), Huize County and Xianfeng (Luo et al., 1980; Yu, 1987b; Qian and Bengtson, 1989) and Baizai (Yu, 1987b), Xundian County Yunnan Province; Zhongyicun and Dahai Members, Zhujiaqing Formation and basal Yu'anshan Formation, Nemakit-Daldynian to Atdabanian (Paragloborilus subglobosus-Purella squamulosa Zone to Watsonella crosbyi Zone possibly Sinosachites flabelliformis-Tannuolina zhangwentangi Zone? Doubtful because one single specimen was found and it is not figured), Meishucun and Wangjiawan, Jinning County, Yunnan Province (Jiang, 1980a; He and Yang, 1982; Luo et al., 1982; Luo et al., 1984; Yu, 1987b; Qian and Bengtson, 1989; Parkhaev and Demidenko, 2010); Tianzhushan Member, Dengying Formation, Nemakit-Daldynian to Tommotian (Paragloborilus subglobosus-Purella squamulosa Zone to Watsonella crosbyi Zone), Songlinpo, Huangjiatang, Yangtze Gorge (Chen and Zhang, 1980; Chen et al., 1981; Xing et al., 1984), and Tianzhushan (Yu, 1987b), Yichang County, Hubei Province; Niuniuzhai Member, Dengying Formation, Nemakit-Daldynian to Tommotian (Paragloborilus subglobosus-Purella squamulosa Zone to Watsonella crosbyi Zone), Niuniuzhai, Leibo County, Sichuan Province (He, 1984).

Genus PROTOCONUS Yu, 1979

1979 Protoconus Yu, 1979, p. 242.

1987b Protoconus; Yu, p. 229.

1988 Protoconus; Kerber, p. 174.

1990 Patellella Vassiljeva, 1990, p. 9.

1996 Gonamella Valkov and Karlova; Esakova and Zhegallo, p. 163 (partim quoad G. orolgainica).

1998 Patellella Vassiljeva; Vassiljeva, p. 75.

2010 Protoconus; Parkhaev and Demidenko, p. 1045-1047.

Type species. Protoconus crestatus Yu, 1979, Nemakit-Daldynian to Tommotian? (Paragloborilus subglobosus-Purella squamulosa Zone to Watsonella crosbyi Zone?), Huangshandong, Yichang County, Hubei Province, China.

Emended diagnosis. Shell low cap-shaped, depressed, and moderately wide. Apex obtuse and displaced posteriorly up to posterior apertural margin. Dorsal side convex, with a rounded dorsal postero-anterior arch, bordered by shallow depressions, laterally compressed. Subapical field short and concave. Aperture oval or subelliptical, 
anterior margin slightly curved upwards (emended after Yu, 1987b and Parkhaev and Demidenko, 2010).

\section{Protoconus orolgainicus (Zhegallo in Esakova and Zhegallo, 1996) \\ Figure 5.1-11}

1988 Protoconus crestatus Yu; Kerber, p. 175176, pl. 9, figs. 4-8.

1996 Gonamella orolgainica Zhegallo in Esakova and Zhegallo, 1996, p. 163-164, pl. XIX, figs. 3, 4 .

Material. About 15 specimens including USTL1215/13, USTL1264/11 and USTL1241/11 preserved as phosphatic internal molds occasionnally associated with fragments of external molds (Figure 5.1) or phosphatised endolithic-microborers (Figure 5.2).

Distribution. Section $\mathrm{K} 2$, sample $\mathrm{K} 2 /{ }_{3 \mathrm{~b}}, \mathrm{~K} 2 /{ }_{6}$, and $\mathrm{K} 2 /{ }_{12 \mathrm{~m}}$; section $\mathrm{K} 3$, samples $\mathrm{K} 3 \mathrm{~T} / 3 \mathrm{a}$ and $\mathrm{K} 3 \mathrm{~T} / 4 \mathrm{a}$; Section 5 , samples $\mathrm{K} 5 / 3, \mathrm{~K} 5 / 25$, and $\mathrm{K} 5 / 32$.

Description. The internal molds are almost bilaterally symmetrical, low cap-shaped (height/length ratio ranging from $3 / 8$ to $5 / 9$ ), up to $1770 \mu \mathrm{m}$ long, $1370 \mu \mathrm{m}$ wide, and $860 \mu \mathrm{m}$ high. The conch is variably laterally compressed (width/length ratio ranging from $2 / 3$ to $6 / 7$ ) so that the aperture is more or less oval in outline (Figure 5.1,5.7). The blunt and hemispherical apex is at about $3 / 4$ of the distance from the anterior margin to the subapical border (Figure 5.1, 5.7), so that the surface under the apex (subapical field) is significantly smaller than the surface above it (dorsal field). The dorsal field is convex in lateral view (Figure 5.2, 5.4, 5.8, 5.10). A wide, dorsal, median-buttress, flanked by two lateral furrows, runs from the subapical field to the anterior margin (Figure 5.2, 5.4, 5.7-8). The buttress is about $1 / 3$ to $1 / 4$ of the conch width. The two subparallel furrows are faint in the subapical and anterior areas and wide (about $50 \mu \mathrm{m}$ ) and moderately deep dorsally (Figure 5.1-6, 5.8). In a few specimens, the two lateral furrows are bordered by two faint constrictions (upper arrow in Figure 5.1). The subapical field is strongly concave. It is subhorizontal near the posterior margin, delimiting a large subapical shelf (Figure 5.7-11). In anterior/posterior view, the lateral fields are straight (Figure 5.5-6). Polygonal structures of approximately $5 \mu \mathrm{m}$ in diameter are visible in the furrows parallel to the dorsal median buttress (Figure 5.3) and on the subapical shelf (Figure 5.10-11). Some specimens (Figs. 5.1-5) display fragments of external molds. The space between internal and external molds (considered to represent the shell thickness) is thin except in the furrows (right arrow in Figure 5.1) and subapical shelf (left arrow in Figure 5.1), where it considerably thickens up to 70 $\mu \mathrm{m}$. The external coating does not show any peculiar structure (Figure 5.4).

Remarks. $P$. orolgainicus was originally described within the genus Gonamella (Esakova and Zhegallo, 1996). However, Parkhaev and Demidenko (2010) suggested that their very low conch is characteristic of the genus Protoconus. Moreover, the presence of a median buttress flanked by lateral furrows is also a feature of the genus Protoconus. We reassign therefore Gonamella orolgainicus to the genus Protoconus.

The morphology of internal molds of the genus Protoconus is similar to that of the genus Purella. Nevertheless, the presence of a subapical shelf has never been described among Purella internal molds. Furthermore, the presence of a smooth external coating in some specimens of $P$. orolgainicus studied herein differentiates it from Purella species because they exhibit highly ornamented shells associated with ornamented external coatings.

The faint concentric striations present on the internal mold of the specimen figured in Esakova and Zhegallo (1996; pl. 19, figs. 3, 4) are absent in all the specimens studied herein. However, the external molds illustrated by Kerber (1988; pl. 9, fig. 4) display such concentric striations corresponding to striations of the shell. The fragments of external coating suggest that the dorsal parallel furrows might at least partly correspond to longitudinal thickening of the shell, forming inner keels. The polygonal imprints observed on the internal molds may correspond to replica of a prismatic shell layer.

Comparisons. Specimens from Mongolia (figured in Esakova and Zhegallo,1996; pl. XIX, figs. 3, 4) and France share the same shape, particularly the presence of a large subapical shelf, which is distinctive of Protoconus orolgainicus among Protoconus species.

Other occurrences. Bayan-Gol Formation, Nemakit Daldynian (Anabarella plana Zone), Bayan-Gol, Orolgay-Gol, Tayshir and Tsahir Haalgany Nuruu, Khasagt-Khairkhan range, Western Mongolia (Esakova and Zhegallo, 1996).

Genus BEMELLA Missarzhevsky in Rozanov et al., 1969

1966 Helcionella (Grabau and Shimer); Rozanov and Missarzhevsky, p. 96. 


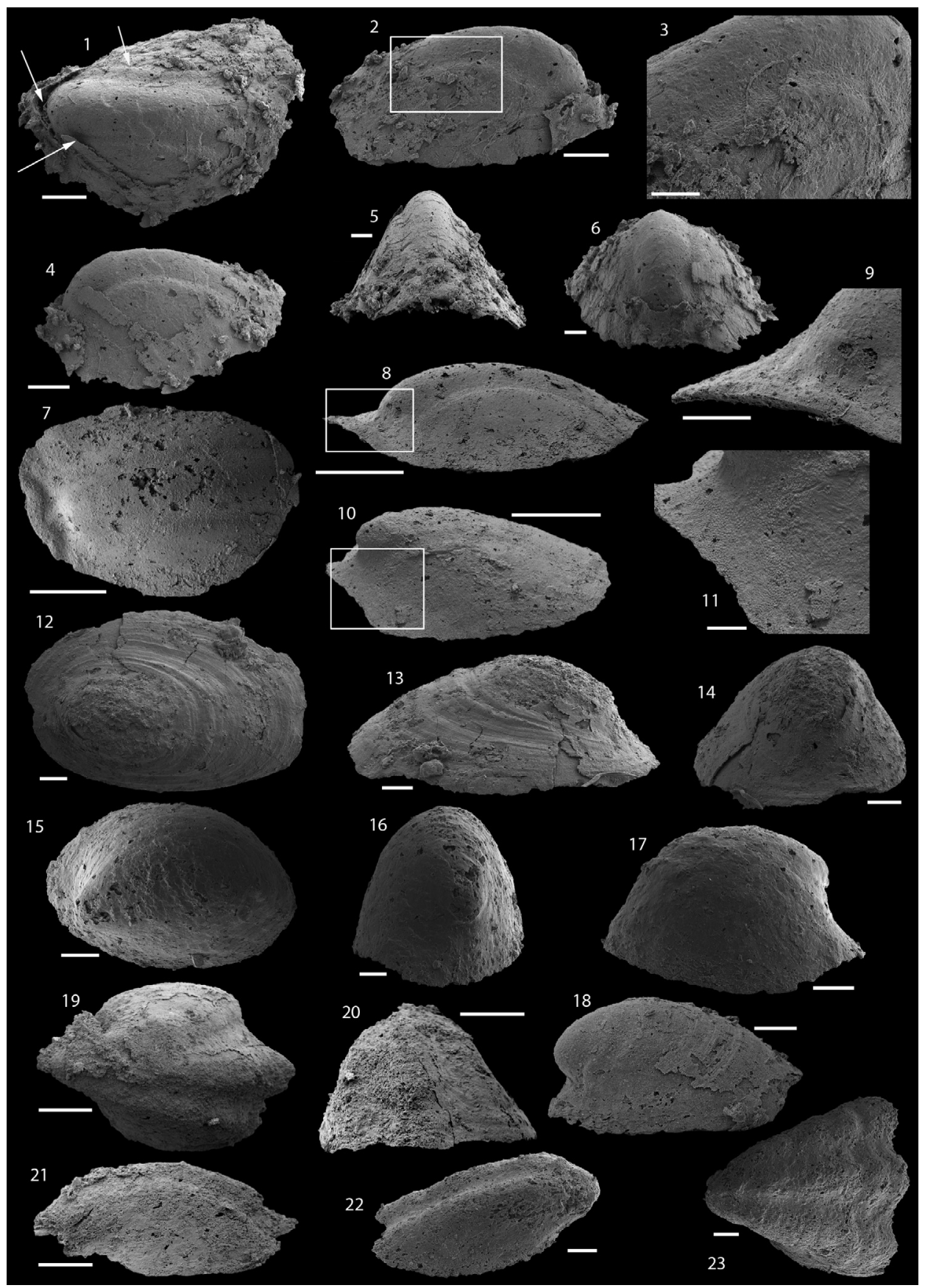

FIGURE 5. 1-11. Protoconus orolgainicus (Zhegallo in Esakova and Zhegallo, 1996). 1-6. USTL1215/13; 1. Upper view, upper arrow shows lateral furrows borded by faint constrictions, lower arrows show space between internal and external molds (shell thickness); 2 . Left lateral view, square shows location of 3; 3 . Detail of polygonal structures in the furrows framing the dorsal median buttress; 4. Right lateral view; 5, 6. Anterior and posterior views respectively. 7-9. USTL1264/11: 7. Upper view; 8. Right lateral view, square shows location of 9; 9. Detail of subapical shelf. 10-11. USTL1241/11: 10. Right lateral view, square shows location of 11; 11. Detail of subapical shelf. 12-18. Bemella cf. simplex Yu, 1979. 12-14. USTL1223/15: 12. Upper view with comarginal striations; 13. Left lateral view; 14. Posterior view. 15-17. USTL1236/6: 15. Upper view with apex shifted to the right; 16. Posterior view; 17. Left lateral view. 18. USTL1256/11: right lateral view of a specimen with curved apex and striated external coating. 19-23. Prosinuites tripartitus Kerber, 1988. 19-21 USTL1257/2: 19. Upper view; 20. Anterior view with dorsal furrows and anterior apertural margin sinus; 21. Right lateral view with apex overhanging the posterior apertural margin. 22-23. USTL1235/4: 22. Left lateral view; 23. Upper view of the dorsal field with sinusoidal growth lines. Scale bars equal: $3,50 \mu \mathrm{m} ; 5,6,11,12-14,100 \mu \mathrm{m} ; 1,2,4,9,16,18,22,23,200 \mu \mathrm{m} ; 15,17,300 \mu \mathrm{m} ; 7,8,10,19-21,500 \mu \mathrm{m}$. 
1969 Bemella Missarzhevsky in Rozanov et al., 1969, p. 137.

1978 Kalbyella Berg-Madsen and Peel, 1978, p. 116.

1979 Bemella; Yu, p. 177.

1979 Eosoconus Yu, 1979, p. 241 (partim quoad E. formosus).

1979 Latirostratus Yu, 1979, p. 2440.

1980 Bemella; Yin et al., p. 154.

1980a Sacciconus Jiang, 1980, p. 118.

1981 Helcionella; Brasier and Hewitt, p. 29.

1982 Bemella; Khomentovsky et al., p. 19.

1982 Bemella; Luo et al. 1982, p. 190.

1984 Sichuanospira He gen. nov.; He 1984, p. 26.

1984 Bemella; Brasier 1984, p. 243.

1984 Bemella; Fedorov 1984, p. 6.

1984 Bemella; Valkov and Karlova 1984, p. 24.

1984 Bemella; Zhou and Xiao 1984, p. 137.

1984 Rostroconus $\mathrm{He}$ in Xing et al., 1984, p. 166.

1987b Latirostratus Yu; Yu 1987b, p. 152.

1989 Bemella; Missarzhevsky 1989, p. 175.

1989 Bemella; Qian and Bengtson 1989, p. 116.

1990 Bemella; Vassiljeva 1990, p. 5.

1990 Charaulachella Vassiljeva, 1990, p. 7.

1994 Bemella; Feng et al. 1994, p. 5.

1994 Repenoconus Feng, Qian and Rong in Feng et al., 1994, p. 4, 16.

1996 Bemella; Esakova and Zhegallo, p. 160.

1998 Bemella; Vassiljeva, p. 72.

1998 Charaulachella; Vassiljeva, p. 73.

2000 Striatoconus Feng, Sun and Qian in Feng et al., 2000, p. 363, 370.

2001 Bemella; Gravestock et al., p. 152.

2010 Bemella; Parkhaev and Demidenko, p. 1027-1028.

Type species. Bemella jacutica (Missarzhevsky in Rozanov and Missarzhevsky, 1966), Tommotian (Nochoroicyathus sunnaginicus Zone to Dokidocyathus regularis Zone), Lena River, Uchur-Maya region, Siberian Platform, Russian Federation.

Emended diagnosis. Shell cap-shaped, low or even depressed, moderately compressed laterally. Apex blunt and rounded, inclined posteriorly, and shifted up to posterior apertural margin. Anterior field convex, posterior concave, rather short. Aperture simple, without sinuses and flaring, oval or irregularly oval. Ornamentation usually represented by concentric folds and/or fine striations, rarely radial ribs or striations can be present (emended after Rozanov et al., 1969 and Parkhaev and Demidenko, 2010).

\section{Bemella cf. simplex Yu, 1979}

Figure 5.12-18

Material. 14 specimens including USTL1236/6 preserved as phosphatic internal molds and two specimens (USTL1223/15 and USTL1256/11) preserved as phosphatic internal mold associated with phosphatic external coating.

Distribution. Section K2, sample $\mathrm{K} 2 / 4 \mathrm{~b}, \mathrm{~K} 2 / 6$, and $\mathrm{K} 2 /{ }_{16}$; section $\mathrm{K} 3$, samples $\mathrm{K} 3 \mathrm{~T} / 2 \mathrm{e}$ and $\mathrm{K} 3 \mathrm{~T} / 3 \mathrm{a}$; Section 5 , samples $\mathrm{K} 5 / 2, \mathrm{~K} 5 / 12, \mathrm{~K} 5 /_{25}$, and $\mathrm{K} 5 / 39$.

Description. The cap-shaped internal molds are moderately compressed laterally (Figure 5.12, 5.16). The aperture is therefore slightly oval in outline (Figure 5.12, 5.15). The specimens range from about $1100 \mu \mathrm{m}$ in length, $800 \mu \mathrm{m}$ in width, and 500 $\mu \mathrm{m}$ in height up to $2000 \mu \mathrm{m}$ in length, $1350 \mu \mathrm{m}$ in width, and $1400 \mu \mathrm{m}$ in height. The apex is shifted posteriorly in all specimens. It is large and blunt in juvenile specimens; whereas larger specimens exhibit a relatively sharp apex, which is slightly curved downward and laterally (Figure 5.17-18). The dorsal field is strongly (in adult specimens, Figure 5.17-18) to moderately (in juvenile specimens, Figure 5.13) convex in lateral view. Its outline progressively straightens toward the apertural margin in largest specimens (Figure 5.17). The subapical field is concave (Figure 5.13, 5.17-18) and the lateral fields straight (Figure 5.14, 5.16). The outer surface of the internal molds is smooth (Figure5.15-17). The external coating, which is only preserved in the smallest specimens, exhibits fine concentric striations around the apex (Figure 5.12). The striations are slightly fading in the subapical area (Figure 5.14) where they tend to be closer than in the dorsal area (Figure 5.12-13).

Remarks. The identification of possible small (juveniles) and large (adults) specimens in Bemella permits the study of its ontogeny. The coiling of the shell starts in juvenile forms with the apex shifted toward the posterior margin. At this developmental stage, the shell is planispirally coiled since the apex lies in the plan of bilateral symmetry. But when reaching adult stage, the coiling is accompanied by a deviation of the spire (toward left or right side). 
Comparisons. The specimens of the genus Bemella studied herein exhibit a smooth surface of the internal mold, a blunt and slightly hooked apex, and the presence of fine concentric striations on the external coating. Those features are similar to those of Bemella simplex Yu, 1979, but the insufficient number of available characters prevents definitive species assignment. However, it differs from Bemella amplaperata (Yu, 1979) and Bemella jacutica (Missarzhevsky in Rozanov and Missarzhevsky, 1966). The latter is more or less tightly coiled into almost one whorl whereas the former exhibits a weak coiling. Bemella cf. simplex also differs from Bemella malycanica (Missarzhevsky in Rozanov and Missarzhevsky, 1966) by its looser coiling. Nevertheless, fine concentric striations are described on $B$. malycanica protoconch and on the rest of the conch, in addition to the usual concentric folds, which is a feature also found in juveniles of Bemella cf. simplex. Bemella cf. simplex is distinguished from Bemella septata (Missarzhevsky in Rozanov and Missarzhevsky, 1966) by the absence of radial structures present on internal molds of $B$. septata. Bemella cf. simplex differs from Bemella minuta Luo et al., 1982 in the more rounded outline of its aperture. Bemella cf. simplex is similar to Bemella incomparabilis Parkhaev in Gravestock et al., 2001, B. communis Parkhaev in Gravestock et al., 2001, B. parula Missarzhevsky in Rozanov et al., 1966, B. bella Chen and Zhang, 1980, and B. multicarinata Chen and Zhang, 1980. Bemella lata (Cobbold, 1935) is also similar to $B$. cf. simplex but the comparison is difficult due to poor illustrations and descriptions of the former. Nevertheless, the juvenile forms of $B$. incomparabilis, B. communis, B. lata, B. bella, and B. multicarinata have not yet been described so, until their description, the comparison with $B$. cf. simplex remains incomplete. It is difficult to compare Bemella cf. simplex and B. sacciformis (Jiang, 1980a) due to the poor preservation and inadequate illustration and description of the latter.

Other occurrences. The following occurrences refer to $B$. simplex: Nemakit-Daldynian to Tommotian (Anabarites trisulcatus-Protoherzina anabarica Zone, Paragloborilus subglobosus-Purella squamulosa Zone and Watsonella crosbyi Zone) of China: Zhongyicun Member and Dahai Member, Zhujianqing Formation, Meishucun, Jinning County (Luo et al., 1980; Feng et al., 2000; Parkhaev and Demidenko, 2010), Xianfeng (Qian and Bengtson, 1989; Feng et al., 2000) and Baizai (Feng et al., 2000), Xundian County, Xiaotan, Yongshan County, Laoheba, Leibo County, Laogongshen,
Mabian County and Fandian, Leshan County, Yunnan Province (Yu, 1987b; Parkhaev and Demidenko, 2010); Mofangyan Member, Tongying Formation, Shatan, Nanjiang County, Sichuan Province (Yu, 1987b); Huangshandong Member, Tongying Formation, Tianzhushan and Huangshandong, Yichang County, Hubei Province (Yu, 1979; 1987b).

$$
\text { Genus PROSINUITES Poulsen, } 1967
$$

1967 Prosinuites Poulsen, 1967, p. 19.

1988 Prosinuites; Kerber, p. 174.

Type species. Prosinuites bornholmensis Poulsen, 1967, Atdabanian (equivalent of the Holmia torelli Zone), between the localitites of Grodby and Grammegd, Bornholm, Denmark.

Emended diagnosis. Shell bilaterally symmetrical, cap-shaped, with blunt apex overhanging the posterior margin. The aperture is oval to rounded subtriangular. Dorsal field with curved crests or longitudinal bulges. Anterior and posterior margin with broad shallow sinuses; anterior sinuses having a tendency to generate a more or less obscure selenizone. Presence of irregular growth lines that extend convexly on the flanks. They are curved sinusoidally on the median dorsal line (emended after Poulsen, 1967 and Kerber, 1988).

\section{Prosinuites tripartitus Kerber, 1988}

Figure 5.19-23

1988 Prosinuites tripartitus Kerber, 1988, p. 174, pl. 9, figs. 1-3.

Material. 2 phosphatic internal molds (USTL1235/ 4 and USTL1257/2).

Distribution. Section $\mathrm{K} 3$, sample $\mathrm{K} 3 \mathrm{~T} / 2 \mathrm{e}$ and section $\mathrm{K} 5$, sample $\mathrm{K} 5 / 12$.

Description. The internal molds of the conchs are low cap-shaped (height/length ratio of $1 / 2$ with a maximum height of $1150 \mu \mathrm{m}$ and length of 2570 $\mu \mathrm{m}$ ) and roughly bilaterally symmetrical (Figure $5.19,5.23)$. The internal molds are slightly laterally compressed (maximum width of $1715 \mu \mathrm{m}$, width/ length ratio of 2/3). The sharp apex is shifted toward the posterior side (sensu Poulsen, 1967) and overhangs the posterior apertural margin (Figure 5.21-22). The aperture is rounded (Figure 5.19 ) to triangular (Figure 5.23) with two sinuses in the anterior region. The sinuses of the apertural margin lead to two dorsal furrows (Figure 5.19-20, 5.23) which divide the dorsal side into three ridges running from the apex to the anterior apertural margin (Figure 5.19-20, 5.23). The ridges are relatively narrow in the apical area but broaden toward the anterior margin (Figure 5.19, 5.23). The subap- 
ical field is concave, without any particular structure (Figure 5.21-22). The lateral fields are straight (Figure 5.20). The outer surface of the internal molds display irregular, sinuous, and coarse growth lines (Figure 5.23).

Comparisons. Prosinuites tripartitus Kerber, 1988 differs from P. bornholmensis Poulsen, 1967 in the more triangular aperture and the more pronounced ridges and separating furrows of the dorsal side.

Other occurrences. Occurrences of Prosinuites tripartitus Kerber, 1988 outside of Montagne Noire are not reported.

Genus DORISPIRA Parkhaev in Parkhaev and Demidenko, 2010

1964 Helcionella Grabau and Shimer; Robinson, p. 561 (partim quoad D. arguta).

1976 Latouchella Cobbold; Runnegar and Jell, p. 126 (partim quoad D. accordionata, $D$. merino, and $D$. penecyrano).

1994 Latouchella; Geyer, p. 77 (partim quoad D. arguta and $D$. pocateloensis).

1988 Latouchella; Peel, p. 152 (partim quoad D. holmdalense and $D$. pearylandica).

2010 Dorispira Parkhaev in Parkhaev and Demidenko, 2010, p. 1060.

Type species. Dorispira terraustralis (Runnegar and Jell, 1976), Toyonian (Xystridura templetonensis-Redlichia chinensis Zone), New South Wales, Australia.

Diagnosis. See Parkhaev and Demidenko (2010). Dorispira lauta? (Yu, 1979)

Figure 6.1-7

1979 Latouchella lauta Yu, 1979, p. 252, pl. II, fig. 27.

1987b Latouchella lauta; Yu, p. 183, pl. 41, figs. 10,11 , pl. 42, figs. 5

Material. 2 slightly broken phosphatic internal molds including USTL1245/6.

Distribution. Section $\mathrm{K} 3$, sample $\mathrm{K} 3 \mathrm{t} / 3 \mathrm{a}$; Section 5 , sample $\mathrm{K} 5 / 40$.

Description. The internal mold is relatively low conical, cap-shaped, (height/length ratio of 5/9, $2000 \mu \mathrm{m}$ in length, and $1100 \mu \mathrm{m}$ in height) and moderately laterally compressed (width/length ratio of $1 / 2$ with $950 \mu \mathrm{m}$ in width). The aperture is subelliptical, with the anterior margin narrower than the posterior one (Figure 6.5). The apex is blunt, rounded, eccentric (shifted toward the posterior margin), and curved downward (Figure 6.1-2). In lateral view, the anterior field (from the apex to the anterior margin) is strongly convex, with the stron- gest convexity near the apex (Figure 6.1-2). A faint median buttress runs throughout the anterior field (from the apex to the anterior apertural margin). Its width is constant and it is flanked by two furrows, in which imprints of the prismatic shell layer are visible (Figure 6.3). Wavy structures are visible on the internal mold of the median buttress (Figure 6.5). They may correspond to irregular comarginal ribs. The posterior field (from the apex to the posterior margin) is highly concave and forms a shelf ("parietal train" sensu Parkhaev, 2010). The same imprints as previously described are present (Figure 6.6). The posterior apertural margin is folded toward the apex with an angle estimated at $125^{\circ}$ (although one side of the folded posterior apertural margin is damaged; Figure 6.6). This fold in the posterior apertural margin results in the formation of a sinus leading to the internal cavity of the conch. The lateral fields are slightly convex to straight (Figure 6.3-4).

Other occurences. $D$. lauta is known only in Nemakit-Daldynian to Tommotian (Paragloborilus subglobosus-Purella squamulosa Zone to Watsonella crosbyi Zone) of China: Huangshandong Member, Tongying Formation, Huangshandong and Tianzhushan, Yichang County, Hubei Province (Yu, 1979; 1987b); Zhongyicun Member, Tongying Formation, Xianfeng, Xundian County, Yunnan Province (Yu, 1987b).

Genus OBSCURANIA Devaere, Clausen, and Steiner, Gen. nov.

http://zoobank.org/E3A1D395-A7AC-4224-A0968ED51D34B5C4

1989 Punctella Zhong; Missarzhevsky, p. 176.

1990 Obscurella Vassiljeva, 1990.

1998 Auricullina Vassiljeva, 1998, p. 79.

2000 Punctella; Kouchinsky, p. 138.

2006 Auricullina; Parkhaev, p. 20.

Type species. Obscurania auriculata (Vassiljeva, 1990), Tommotian, Siberian Platform, Russian Federation.

Emended diagnosis. Shell cap-shaped, depressed, relatively wide. Apex acute or blunt, shifted back beyond posterior apertural margin, and slightly curved downwards. Anterior field convex, lateral fields slightly convex or flattened, posterior field short and slightly concave. Aperture subelliptical to circular, with widely rounded anterior and occassionally protracted posterior margins. Outer shell smooth. Internal mold covered by small papillae or cylindrical granules (emended after Parkhaev, 2006). 


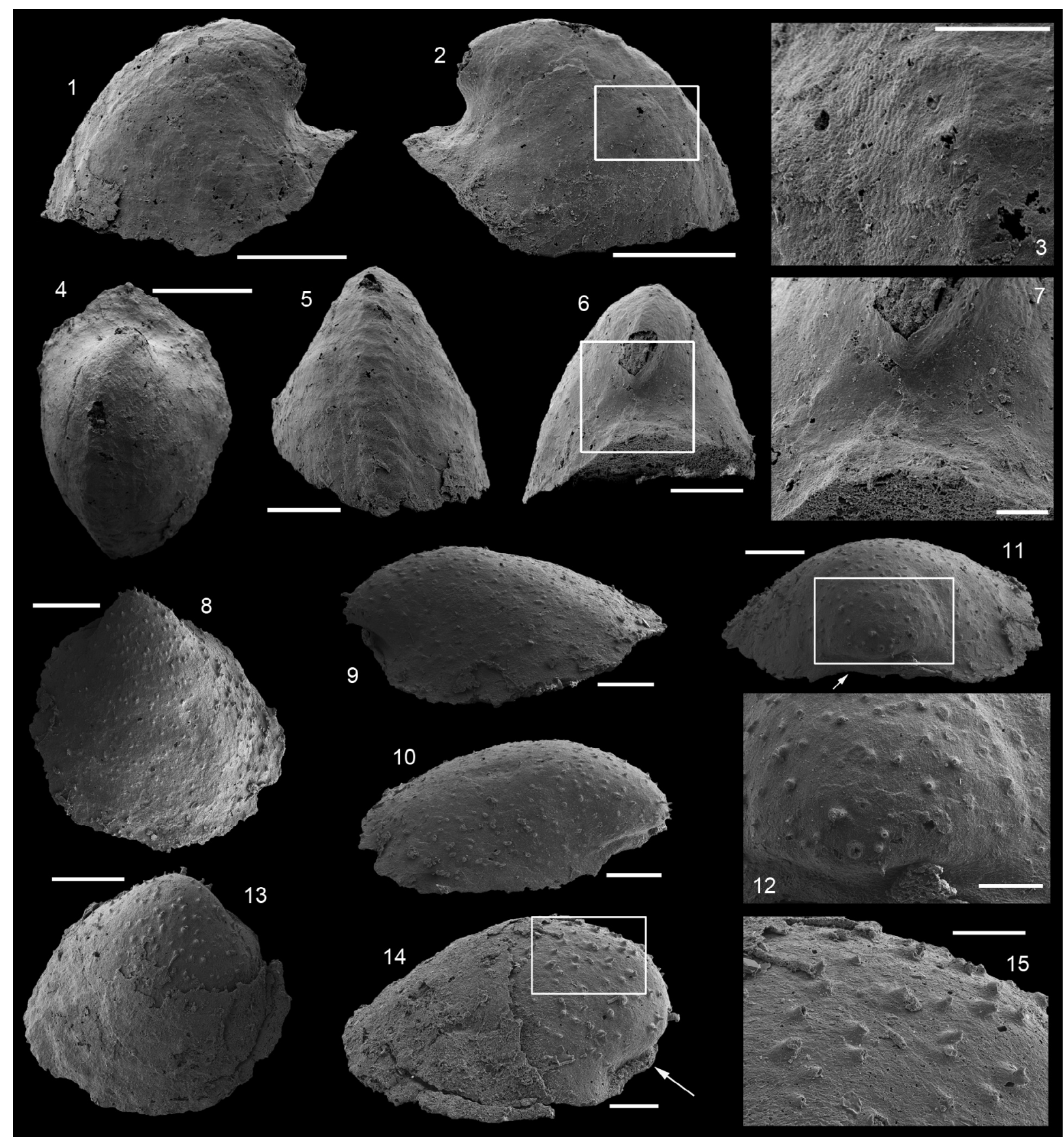

FIGURE 6. 1-7 Dorispira lauta? (Yu, 1979). 1-7: USTL1245/6: 1. Left lateral view; 2. Right lateral view, square shows location of 3. 3. Detail of latero-dorsal furrow with polygonal imprints; 4 . Upper view with prominent subapical shelf; 5. Anterior view showing mid-dorsal buttress with wavy structures; 6 . Posterior view, square shows location of $7 ; 7$. Detail of subapical field. 8-15. Obscurania tormoi Devaere, sp. nov. 8-12 USTL1223/7: 8. Upper view; 9. Right lateral view; 10. Left lateral view; 11. Posterior view, square shows location of 12; 12 . Detail of the apex with mammilated papillae. 13-15. USTL1223/20: 13. Upper view of internal mold with external coating on anterior part; 14. Left lateral view, square shows location of $15 ; 15$. Detail of apically curved mammilated papillae. Scale bars equals: 15, $50 \mu \mathrm{m} ; 3,7,12$, $14,100 \mu \mathrm{m} ; 9,10,11,13,200 \mu \mathrm{m} ; 5,6,8,300 \mu \mathrm{m} ; 1,2,4,500 \mu \mathrm{m}$. 
Remarks. Herein we propose a new generic name Obscurania nom. nov. to replace the genus Obscurella Vassiljeva, 1990, which is preoccupied by the generic name Obscurella Clessin in Kuster et Clessin, 1889, a recent operculate landsnail of the family Cyclophoridae.

\section{Obscurania tormoi Devaere, Clausen, and Steiner, sp. nov. \\ Figure 6.8-15 \\ http://zoobank.org/C5C1A517-3AF2-4A3B-8E4A- 16F957355FB3}

Etymology. In honour of Nicolas Tormo, amateur geologist, who gave great help during field work.

Holotype. USTL1223/20, Figure 6.13-15; phosphatic internal mold with external coating, from Marcou village, Heraultia Limestone, sample K2/16.

Material. 3 specimens including USTL1223/7 and USTL1223/20 preserved as phosphatic internal molds, one with fragments of external molds (Figure 5.13-15).

Diagnosis. Low, cap-shaped, wide conch, circular in outline. Apex in the plan of symmetry and overhanging the subapical apertural margin. Subapical field strongly concave with a labrum and a relativelly wide sinus of the posterior margin. Outer surface of internal mold ornamented by small, closely spaced mammilate papillae pointing apically and occassionally pierced by a central canal. External coating smooth and presence of a small peripheral skirt.

Distribution. Section K2, sample K2/ 16 .

Description. The internal molds of the conchs are low cap-shaped, up to $1180 \mu \mathrm{m}$ long, $1105 \mu \mathrm{m}$ wide, and $580 \mu \mathrm{m}$ high (height/length ratio up to $1 /$ 2). The aperture is circular in outline (Figure 6.8, 6.13). The rounded to sharp apex lies in the plane of symmetry (Figure $6.8,6.13$ ). It is shifted posteriorly and overhangs the subapical apertural margin (Figure 6.9-10). The dorsal field is convex in lateral view (Figure 6.9, 6.11, 6.14). The posterior margin has a relatively wide sinus of limited height (100 $\mu \mathrm{m}$, Figure 6.10). The subapical field (the surface under the apex) is highly concave (Figure 6.10-11) and formed by a subapical labrum (arrowed in Figure $6.11,6.14$ ) delimited by a vertical fold of the shell bordering the posterior margin, and separated from the apex by a large and shallow furrow (Figure 6.10). The lateral fields are slightly convex to straight in subapical view (Figure 6.11). The outer surface of the internal mold is ornamented by small, closely spaced mammilate papillae (Figure $6.12,6.15)$. The papillae, which are $15 \mu \mathrm{m}$ in average diameter and height, point apically and are occassionally pierced by a central canal (Figure $6.10,6.15)$. They might replicate the pore structure of the original shell. The external coating is more rarely present and consists of a flat and smooth layer (Figure 6.13). On one specimen, a peripheral lamella of the partly preserved external-coating borders the internal molds, which might indicate the presence of a small peripheral skirt, (almost) parallel to the main apertural plane (Figure 6.1315).

Comparisons. O. tormoi differs from the two other species of the genus (O. auriculata Vassiljeva, 1990 and O. granulosa Parkhaev, 2006) in its subapical labrum and peripheral skirt. It also differs from $O$. auriculata in its circular vs elongate subelliptical aperture. Moreover, the apex of $\mathrm{O}$. auriculata is less posteriorly shifted than seen in the new described material; its subapical field is less concave, and flattens below the apex. O. tormoi and $O$. auriculata differs from O.granulosa in the mammilate instead of granulate ornamentation on internal molds, both diagnostic of the genus.

Other occurrences. Occurrences of Obscurania tormoi Devaere, sp. nov. outside of Montagne Noire are not reported.

\section{Genus IGORELLA Missarzhevsky in Rozanov et al., 1969}

1969 Igorella Missarzhevsky in Rozanov et al., 1969, p. 141.

1979 Maidipingoconus Yu, 1979, p. 253.

1981 Chabaktiella Missarzhevsky in Missarzhevsky and Mambetov, 1981, p. 50.

1981 Igorella; Missarzhevsky and Mambetov, p.50.

1981 Songlinella Chen, Chen and Zhang in Chen et al. 1981, p. 37.

1989 Igorella; Missarzhevsky, p. 172.

1989 Igorellina Missarzhevsky, 1989, p. 175.

1994 Dianella Wang, 1994, p. 11.

1998 Bemellina Vassiljeva, 1998, p. 77.

1998 Compressoconus Vassiljeva, 1998, p. 79.

2010 Igorella; Parkhaev and Demidenko, p. 1028.

Type species. Igorella ungulata Missarzhevsky in Rozanov et al., 1969, Tommotian (Nochoroicyathus sunnaginicus Zone), West Anabar, and Uchur-Maya regions, Siberian Platform, Russian Federation.

Emended diagnosis. Shell cap-shaped, high, considerably compressed laterally. Apex inclined 
and displaced posteriorly, significantly projecting over posterior apertural margin. Anterior field convex, posterior field concave, and relatively long. Aperture oval or elliptical, simple, without sinuses or labrum. Ornamentation represented by concentric folds or ribs developed to different extent, rarely radial ribs or striation can be present (emended after Parkhaev and Demidenko, 2010).

$$
\begin{gathered}
\text { Igorella sp. } \\
\text { Figure } 7.1-10
\end{gathered}
$$

Material. 5 phosphatic internal molds including USTL1227/5 and USTL1250/1.

Distribution. Section $\mathrm{K} 3$, sample $\mathrm{K} 3 \mathrm{~B} / 6$; Section 4 , sample $\mathrm{K} 4 /_{4 \mathrm{a}}$; Section 5 , sample $\mathrm{K} 5 \mathrm{~b} / 2, \mathrm{~K} 5 / 32$, and $\mathrm{K} 5 / 39$.

Description. The internal molds of univalve conchs are variably laterally compressed (Figure 7.3-5, 7.7, 7.9-10) and loosely coiled into half a whorl (Figure 7.1-2, 7.6, 7.8). Their length is up to $2050 \mu \mathrm{m}$, width up to $950 \mu \mathrm{m}$ and height $1100 \mu \mathrm{m}$, so the width/length and height/lenght ratios are about $1 / 2$. The aperture is oval in outline (Figure 7.5). The dorsal field is convex near the apex but straightens toward the aperture (Figure 7.1-2, 7.6, 7.8). The subapical field is deeply concave (Figure 7.1-2, 7.6, 7.8). The lateral fields are straight (taphonomically? e.g., Figure $7.3,7.4$ ) to slightly concave (Figure 7.7, 7.10). The apex is curved downward and overhangs the subapical apertural margin (Figure 7.1-2, 7.6, 7.8); it is smooth and sharp (Figure $7.3,7.10$ ). The external surface of internal molds displays comarginal ribs that cross the dorsum, but greatly varies in expression due to differences in preservation (Figure 7.1-5 vs $7.6-$ 10). The ribs have a rounded triangular shape in profile (Figure 7.6). They are straight in the dorsal region but tend to become curved toward the subapical field (Figure 7.8).

Comparisons. The French specimens are hardly assigned to a species because they are incompletely preserved, preventing the identification of some diagnostic characters, such as the presence of a marked protoconch separated from the rest of the conch by a constriction (I. mostrosa and its probable junior synonyms I. laevis, I. Talassica, and $I$. arta), or the presence of fine concentric striations (I. ungulata). The small amount of available characters leads to a possible assignment of the present specimens to either $I$. emeiensis, $I$. Hamata, or I. maidipingensis. However, the specimens of Montagne Noire are much lower than $I$. sanxiensis and lack the radial striations described in I. ungulata. They are therefore not assigned to these species.

Other occurrences. The genus Igorella is known from the Nemakit-Dadynian to Tommotian of the Siberian and Yangtze platforms (Parkhaev and Demidenko, 2010).

Class DIPLACOPHORA Vinther and Nielsen, 2005 Order HALWAXIIDA Conway Morris and Caron, 2007

Discussion. The morphological terminology used herein follows Bengtson and Conway Morris (1984) and Qian and Bengtson (1989). The distal end of the sclerite corresponds to the apex whereas the proximal one can be identified through the presence of a basal opening referred to as the foramen. Upper and lower sides can be recognised with the upper side usually showing ridges (longitudinal and/or transversal) and a lower side generally smooth. The halwaxiids are herein tentatively assigned to the molluscs following Vinther and Nielsen (2005) and Kouchinsky et al. (2012).

Family HALKIERIIDAE Poulsen, 1967 Genus HALKIERIA Poulsen, 1967

1967 Halkieria Poulsen, 1967, p. 29.

1969 Sachites Meshkova, 1969, p. 165.

1975 Sachites; Matthews and Missarzhevsky, p. 300.

1977 Sachites; Qian, p. 261.

1980 Sachites; Yin et al., p. 192.

1981 Dactyosachites He, 1981, p. 88.

1981 Microsachites He, 1981, p. 89.

1981 Halkieria; Missarzhevsky and Mambetov, p. 64.

1982 Sachites; Luo et al., p. 177.

1984 Halkieria; Bengtson and Conway Morris, p. 312.

1984 Acrosquama Qian and Xiao, 1984, p. 72.

1984 Acuminachites Qian and Yin, 1984, p. 105.

1984 Sachites; Qian and Yin, p. 103.

1985a Halkieria; Bengtson, p. 102.

1988 Halkieria; Kerber, p. 160.

1989 Halkieria; He and Xie, p. 124-125.

1989 Sachites; Qian, p. 189-191.

1989 Halkieria; Qian and Bengtson, p. 41.

1989 Halkieria; Wrona, p. 542.

1990 Halkieria; Bengtson et al., p. 71-73. 


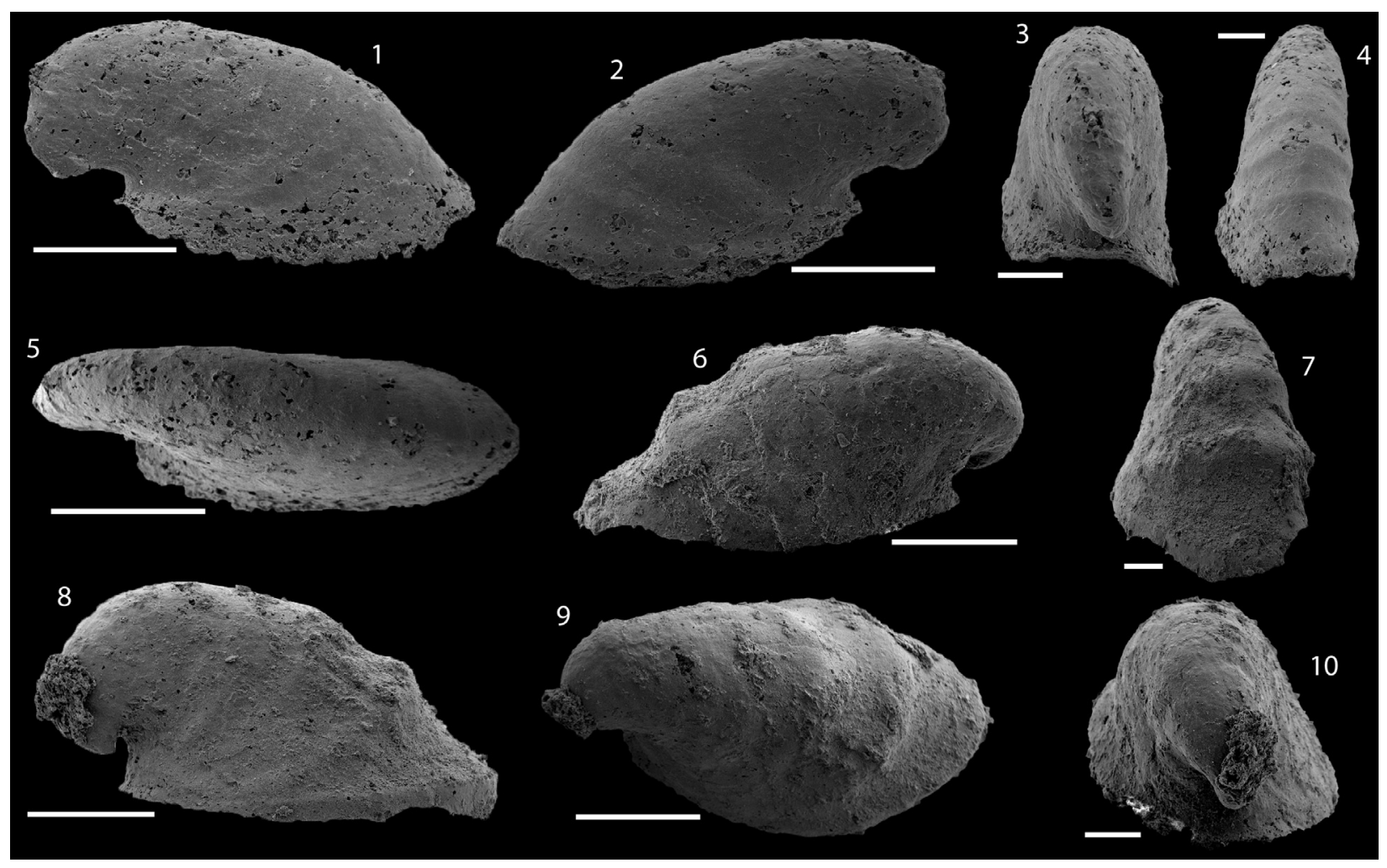

FIGURE 7. 1-10 Igorella sp. 1-5. USTL1227/5: 1. Right lateral view showing loose coiling; 2 . Left lateral view; $3,4$. Posterior and anterior views respectively, showing lateral compression; 5. Upper-lateral view. 6-10. USTL1250/1: 6. Left lateral view; 7. Anterior views with ribs crossing the dorsum; 8. Right lateral view; 9. Upper-lateral view; 10. Posterior view. Scale bars equal: 1, 2, 5, 6, 8, 9, $500 \mu \mathrm{m} ; 3,4,7,10,200 \mu \mathrm{m}$.

1990 Halkieria; Conway Morris and Peel, p. 802.

1996 Halkieria; Esakova and Zhegallo, p. 135136.

1998 Halkieria; Elicki, p. 55-56.

2007 Halkieria; Conway Morris and Caron, p. 1258.

2010 Halkieria; Parkaev and Demidenko, p. 985.

Type species. Halkieria obliqua Poulsen, 1967, Atdabanian (equivalent of the Holmia torelli Zone), Lilleaa and Gredbyaa localities, Bornholm Island,

Denmark.

Diagnosis. See Qian and Bengtson (1989).

Halkieria sacciformis (Meshkova, 1969)

Figure 8.1-16

1969 Sachites sacciformis Meshkova, 1969, p. 166 , pl. 52 , figs. $5-7 ; 1974$, p. 191 , pl. 25 , figs. 13, 14, 20, 21.

1974 Sachites proboscideus Meshkova, 1974, p. 191, pl. 25, figs. 1, 2.

1974 Sachites sacciformis; Sokolov et al., p. 74, pl. 17, figs. $7,8$.
1974 Sachites costulatus Meshkova, 1974, p. 192, pl. XXY, figs. 11, 12, 17, 22.

1975 Sachites sacciformis; Matthew and Missarzhevsky, pl. 3, figs. 17, 18.

1977 Sachites longus Qian, 1977, p. 263, pl. II, figs. 1-6.

1977 Sachites costulatus; Qian, p. 261, pl. 1, figs. 26-29.

1979 Sachites sacciformis; Qian et al., pl. III, figs. 9-11.

1980 Sachites solidus Mostler, 1980, p. 250, pl. 2, figs. 9, 10.

1980 Sachites costulatus; Yin et al., p. 194, pl. 8, figs. 20-22; pl. 19, fig. 1-3.

1980 Sachites sacciformis; Mostler, pl. 1, figs. 8, 22, 24, pl. 2, figs. 2, 4.

1981 Halkieria sacciformis (Meshkova); Missarzhevsky and Mambetov, p. 65, pl. 4, figs. 14, 15, 18; pl. 5, fig. 16.

1982 Sachites costulatus; Luo et al., p. 179, pl. 16, fig. 6. 


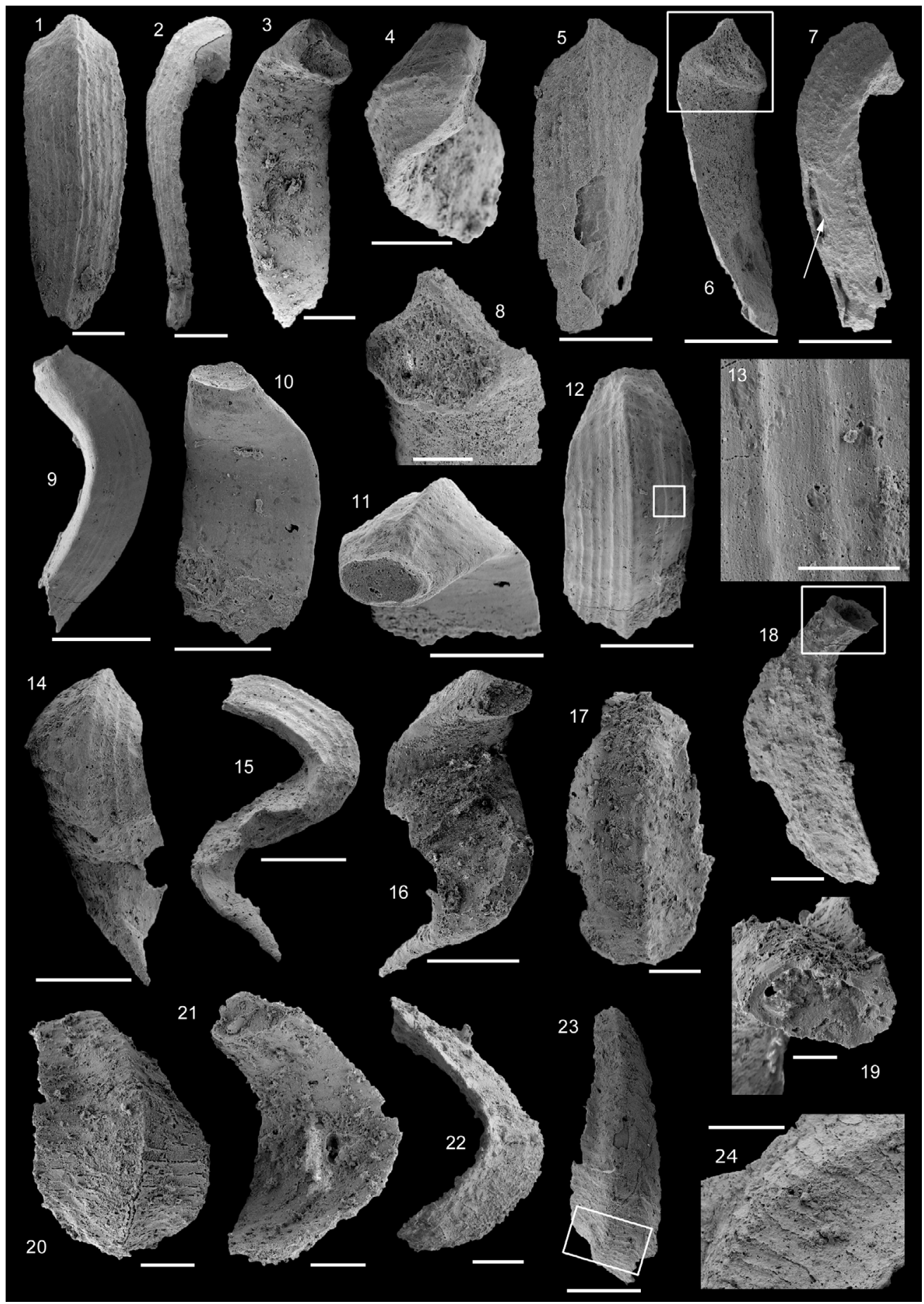

FIGURE 8. 8.1-16. Halkieria sacciformis Meshkova, 1969. 1-4. USTL1257/8: 1. Dorsal view with longitudinal ribs; 2. Lateral view; 3. Ventral view; 4. Proximal view. 5-8. USTL1252/2: 5. Dorsal view with internal cavity cisible; 6 . Ventral view, square shows location of $8 ; 7$. Lateral view, arrow shows internal cavity; 8 . Detail of the triangular base. 9-13. USTL1249/10: 9. Lateral view; 10. Ventral view; 11. Apical view; 12. Dorsal view, square shows location of $13 ; 13$. Detail of the ornamentation of dorsal side. 14-16 USTL1249/6: 14. Dorsal view; 15. Lateral view showing the S-shape of sclerites; 16. Ventral view with distal tip. 17-24. Halkieria operculus (Qian, 1984). 17-19. USTL1250/8: 17. Dorsal view with visible lateral flanges; 18. Ventral view, square shows location of 19; 19. Detail of the base. $20-22$. USTL1250/9: 20. Dorsal view with fine transverse striations; 21. Ventral view; 22. Lateral view. 23-24. USTL1250/7: 23. Dorsal view, square shows location of $24 ; 24$. Detail of the transversal striations. Scale bars equal: $13,19,100 \mu \mathrm{m}$; $8,17,18,20-22,24,200 \mu \mathrm{m} ; 1-7,9-12,14-16,23,500 \mu \mathrm{m}$. 
1983 Sachites sacciformis; Rozanov and Sokolov, p. 166, pl. 63, figs. 7, 8.

1983 Sachites costulatus; Qian and Zhang, p. 88 , pl. 1, figs. $5-8$.

1984 ?Halkieria sp. (palmate sclerite); Bengtson and Conway Morris, p. 312, text-figs. 3A30.

1984 Sachites sacciformis; Valkov and Karlova, p. 22, pl. 2, figs. 8, 9, 11.

1984 Sachites sacciformis; Luo et al., pl. 12, fig. 4.

1988 Halkieria sp. 1; Kerber 1988, p. 161, textfig. 15, pl. 5, figs. 1-10.

1989 Halkieria sacciformis; Missarzhevsky, pl. 23, fig. 10.

1989 Halkieria costulata Missarzhevsky, 1989, pl. XXIII, figs. 1, 2.

1990 Halkieria cf. H. sacciformis; Khomentovsky et al., p. 33, pl. 5, figs. 5-9; pl. 6, figs. 1-4.

1996 Halkieria sacciformis; Esakova and Zhegallo, pl. 10, figs. 12-18.

2010 Halkieria sacciformis; Parkhaev and Demidenko, p. 989 , pl. 5, figs. 1-9, pl. 6, figs. 1-7.

Material. About 50 incomplete and 10 complete cultrate sclerites including illustrated specimens USTL1249/6, USTL1249/10, USTL1252/2, and USTL1257/8 preserved as internal molds possibly associated with external coating.

Distribution. Section K2, samples $\mathrm{K} 2 /{ }_{3 b}, K 2 / 3 m$, $\mathrm{K} 2 /_{4 \mathrm{~b}}, \mathrm{~K} 2 /_{8 \mathrm{a}}, \mathrm{K} 2 /{ }_{12 \mathrm{~m}}, \mathrm{~K} 2 /{ }_{14}$, and $\mathrm{K} 2 /{ }_{16}$; section $\mathrm{K} 3$, samples $\mathrm{K} 3 \mathrm{~T} / 2 \mathrm{c}, \mathrm{K} 3 \mathrm{~T} / 3 \mathrm{a}, \mathrm{K} 3 \mathrm{~T} / 4 \mathrm{a}, \mathrm{K} 3 \mathrm{~B} / 12$, and $\mathrm{K} 3 \mathrm{~B} /$ ${ }_{13}$; section $\mathrm{K} 4$, samples $\mathrm{K} 4 / 4 \mathrm{a}, \mathrm{K} 4 /_{4 \mathrm{~b}}, \mathrm{~K} 4 / 11$, and $\mathrm{K} 4 /{ }_{17}$; section $\mathrm{K} 5$, samples $\mathrm{K} 5 / 2, \mathrm{~K} 5 \mathrm{~b} / 2, \mathrm{~K} 5 \mathrm{~b} / 3, \mathrm{~K} 5 \mathrm{~b} /$ $4, \mathrm{~K} 5 / 12$, and $\mathrm{K} 5 / 32$.

Description. The originally hollow and thin-walled cultrate sclerites are filled with phosphates (Figure $8.5,8.7$ ). They are elongate in shape, compressed in dorso-ventral direction (Figure 8.2, 8.7, 8.9, $8.15)$, and mostly flatten, triangular in cross-section (Figure 8.4, 8.11). The transition between the dorsal (or upper) and ventral (or lower) part is sharp (Figure 8.4, 8.11). The sclerites are almost bilaterally symmetrical (Figure 8.1, 8.12). The proximal end (or base) is slightly curved toward the ventral surface and forms an angle with the longitudinal axis of the blade (or distal part) varying from 130 to $170^{\circ}$ (Figure 8.2, 8.7, 8.9, 8.15). The base is formed by a shelf-like projection directed toward the lower part of the sclerite (Figure 8.2, 8.7, 8.9,
8.15). The base is generally slightly smaller than the blade in width. In some specimens, the width is considerably decreasing from the blade to the base, giving a collar-shape to the base (Figure $8.10-11)$. In cross-section, the base is rhomboidal (Figure 8.3), triangular (Figure 8.6, 8.8), or rounded-triangular (Figure $8.11,8.16$ ). The foramen is occassionally fringed by a prominent flange of the shape of the base cross-section (Figure 8.3). The distal end is undoubtedly pointed in complete specimens (Figure 8.14-16) and the presence of a more rounded distal end is clearly due to breakage and abrasion (Figure 8.1, 8.3). The distal tip points toward the dorsal surface, with the base pointing the lower surface, the sclerites are S-shaped in profile (Figure 8.2, 8.15). The dorsal surface of both internal molds and external coatings are ornamented with longitudinal ribs (Figure 8.1, 8.5, 8.12, 8.14). The central rib is wider and more prominent than other ribs and marks a clear ridge (Figure 8.1, 8.12). The part of the dorsal surface situated between the central ridge and the lateral edges is slightly concave to straight in cross section (Figure $8.4,8.8,8.11$ ). The ribs vary from 6 to 12 in number. In well-preserved specimens, secondary and very small longitudinal lines can be observed between the ribs (Figure 8.13). No ornamentation is visible on the distal tip (Figure 8.14). The ventral surface of the sclerite is flat and smooth (Figure 8.3, 8.6, 8.10, 8.16).

Comparison. Halkieria sacciformis differs from all the other species of Halkieria in the presence of a central rib wider and more prominent than other ribs from the upper surface.

Other occurrences. Bayan-Gol Formation, Nemakit-Daldynian to Tommotian (Halkieria amorpha Zone and Tianzhushania tetramera Zone), Salaany-Gol, Bayan-Gol and Orolgay-Gol, Khasagt-Khairkhan Range, Western Mongolia (Esakova and Zhegallo, 1996). Hazira Formation, Tommotian (Dokidocyathus regularis Zone), Hazara, Pakistan (Mostler, 1980). Uchbas Member, Chulaktau Formation, Tommotian (Bercutia cristata zone), at Kyrshabakty, Aktugay, Uchbas and Berkuty, Kazakstan (Missarzhevsky and Mambetov, 1981). Zhanaary Member and Taldybulak Member, Beshtash Formation, Atdabanian (Rhombocorniculum cancellatum zone), at Beshtash, Talass Alatau, Kyrgyzstan (Missarzhevsky and Mambetov, 1981). Siberia: Kessyusia Formation and base of the Erkeket Formation, Nemakit-Daldynian to Tommotian (Purella antiqua Zone to Dokidocyathus regularis Zone), Olenek Uplift (Valkov, 1987; Missarzhevsky, 1989; Bokova, 1990; Khomen- 
tovsky and Karlova, 1993; Knoll et al., 1995); Pestrotsvet Formation, Tommotian (Nochoroicyathus sunnaginicus Zone to Dokidocyathus regularis Zone), Dzhanda River and Mount Konus near Malyi Chaydakh River (Khomentovsky and Karlova, 1993), Tiktirikteekh Creek (near Isit Village), Bydyangaya Creek, Lena River (Meshkova, 1969; Kruse et al., 1995), Gonam River (Khomentovsky and Karlova, 1993), Nemnekey River (Khomentovsky and Karlova, 1993), Selinde River (Khomentovsky and Karlova, 1993); Members 2 and 3 of the Medvezh'ya Formation, Tommotian (Nochoroicyathus sunnaginica Zone), northwestern flanks of the Anabar Uplift (Khomentovsky and Karlova, 1993).

China: Maidiping Formation, Nemakit-Daldynian to Tommotian (Paragloborilus subglobosus-Purella squamulosa and Watsonella crosbyi zones), Maidiping, Emei County, Sichuan Province (Qian, 1977; Xing et al., 1984); Zhongyicun and Dahai members, Zhujiaqing Formation, Nemakit-Daldynian to Tommotian (Paragloborilus subglobosus-Purella squamulosa and Watsonella crosbyi zones), Meishucun, Jinning County (Luo et al., 1984; Xing et al., 1984), and Dahai and Meishucun, Huize County (Luo et al., 1982; Wang, 1994), Yunnan Province; Upper part of the Huangshandong Formation, Nemakit-Daldynian to Tommotian (Paragloborilus subglobosus-Purella squamulosa and Watsonella crosbyi zones), Tianzhushan, Yichang County, Hubei Province (Qian et al., 1979); Xihaoping Member of the Tongying Formation, Tommotian (Watsonella crosbyi Zone), at Xihaoping, Fangxian County, Hubei Province (Qian and Zhang, 1983).

Halkieria operculus (Qian, 1984)

Figure 8.17-24

1984 Sachites operculus Qian, 1984, p. 104, PI. III, figs. 1-3.

1988 Halkieria sp. 2; Kerber, 1988, p. 162-163, text-fig. 16, pl. 5, figs. 11-18.

1989 Sachites operculus; Qian, p. 193-194, pl. 50 figs. 1 , 2. Non pl. 51 , figs. $9-11$ and $12-$ 14, PI. 52, figs. 12, 13 [recte Halkieria mira]. Non pl. 51, figs. 15, 16, PI. 52, figs. 10, 11 [recte Halkieria maidipingensis].

Material. 20 phosphatic internal molds with partially to completely preserved external coating of cultrate sclerites including USTL1250/7 to USTL1250/9.

Distribution. Section $\mathrm{K} 4$, samples $\mathrm{K} 4 /_{2}, \mathrm{~K} 4 /_{4 a}, \mathrm{~K} 4 /$ 9, $\mathrm{K} 4 / 11$, and $\mathrm{K} 4 /{ }_{17}$; section $\mathrm{K} 5$, samples $\mathrm{K} 5 \mathrm{~b} / 8, \mathrm{~K} 5 /$ $2, \mathrm{~K} 5 /{ }_{12}, \mathrm{~K} 5 / 19, \mathrm{~K} 5 / 32$, and $\mathrm{K} 5 / 35$.
Description. The cultrate sclerites are preserved both as internal and external molds. They are large, broad and flattened, 1 to $2 \mathrm{~mm}$ in length, 400 to $900 \mu \mathrm{m}$ in width (width/length from $3 / 5$ to $1 / 3$ ). The sclerites are very thin (thickness ranging from 180 to $380 \mu \mathrm{m}$, thickness/width ratio from 2/7 to 4/ 7 ; thickness/length ratio from $1 / 8$ to $1 / 3$ ). The general shape is elongate oval (Figure 8.23) to rectangular (Figure 8.17). Most of the specimens are roughly bilaterally symmetrical (Figure $8.17,8.23$ but see Figure 8.20 ). The sclerites are longitudinally curved with generally the strongest curvature near the basal part (Figure 8.18, 8.22). The basal process is bottle-neck shaped in lateral view (Figure 8.18) and highly variable in cross-section (quadrate; Figure 8.19, rounded, oval, triangular; Figure 8.21,). When visible, the foramen is rounded and broad (Figure 8.19). The apical part is rounded and blunt (Figure 8.17, 8.20). The overall cross-section of the sclerite is subtriangular. The lower side is flat to slightly concave (giving the sclerite a transverse curvature) without any ornamentation (Figure 8.21). The upper side is marked by the presence of a keel in the median area occassionally forming a median ridge (Figure 8.17, $8.20,8.23)$. The lateral sides of the upper facet tend to flatten from the median keel toward the margins to finally form flange-like structures (Figure $8.17,8.20)$, whereas the transition from the upper to the lower side is sharp (Figure 8.22). Fine transverse striations ornament the upper side of external coatings (Figure 8.17, 8.23-24). The lower side is smooth (Figure 8.18, 8.21).

Comparison. Halkieria operculus (Qian, 1984) differs from all other species of the genus in the organisation of the dorsal side on two finely transversally striated surfaces separated by a central ridge and flanges on the lateral sides. The Halkieria sclerites described herein are of cultrate and palmate types, each type corresponding to a different species. This sorting might be interpreted as a parataxonomic bias, as the two types may belong to a single biological species.

Other occurrences. Upper Zhongyicun Member, Zhujiaqing Formation, Nemakit-Daldynian (Paragloborilus subglobosus-Purella squamulosa Zone), Xianfeng, Xundian County, Yunnan Province, China (Qian, 1984, 1989).

\section{Family SIPHOGONUCHITIDAE Qian, 1977 Genus SIPHOGONUCHITES Qian, 1977}

1977 Siphogonuchites Qian, Qian, 1977, p. 263.

1977 Palaeosulcachites Qian, 1977, p. 264.

1980 Siphogonuchites; Yin et al., p. 176. 
1980 Palaeosulcachites; Yin et al., p. 177.

1982 Trapezochites Qian and Jiang in Luo et al., 1982, p. 176.

1989 Siphogonuchites; Khomentovsky and Karlova, p. 60.

1989 Siphogonuchites; Qian, p. 197-198.

1989 Palaeosulcachites; Qian, p. 199.

1989 Siphogonuchites; Qian and Bengtson, p. 21.

1996 Siphogonuchites; Esakova and Zhegallo, p. 139.

Type species. Siphogonuchites triangularis Qian, 1977, Tommotian (Watsonella crosbyi Assemblage Zone), Maidiping, Emei County, Sichuan Province, China.

Diagnosis. See Qian and Bengtson (1989).

Siphogonuchites triangularis Qian, 1977

Figure 9.1-11

1977 Siphogonuchites triangulatus [spelled triangularis on p. 278] Qian, 1977, p. 263, pl. 3, figs. 15-16.

1977 Siphogonuchites intermedius Qian, 1977, p. 263, pl. 3 figs. 9-10.

1977 Siphogonuchites pusilliformis Qian, 1977, p. 264 , pl. 3 figs. $13-14$.

1977 Palaeosulcachites biformis Qian, 1977, p. 264, pl. 3, figs. 1-2.

1977 Palaeosulcachites irregularis Qian, 1977, p. 265, pl. 3, figs. 3-4.

1977 Coleollidae; Zhong, pl. 1, figs. 1-6.

1979 Palaeosulcachites shipaiensis Qian, Chen and Chen in Qian et al., 1979, p. 220-221, pl. 3, figs. 15-17.

1980 Palaeosulcachites irregularis; Chen and Zhang, pl. 2, figs. 19, 20.

1980b Sachitelus intercostatus Qian and Jiang in Jiang 1980b, pl. 2, fig. 6.

1980b Trapezochites minuta Jiang, 1980b, p. 85, pl. 4, fig. 4.

1980b Trapezochites chordoides Jiang, 1980b, pl. 3, figs. 3, 7, 16.

1980b Siphogonuchites triangulatus; Jiang, pl. 3, figs. 1, 2, 5.

1980 Siphogonuchites triangularis; Luo et al., pl. 1, fig. 12.

1980 Palaeosulcachites biformis; Yin et al., 177, pl. 19, figs. $30-33$.
1982 Siphogonuchites pusilliformis; Voronin et al., 64, pl. 7, fig. 2.

1982 Siphogonuchites triangularis; $\mathrm{He}$ and Yang, pl. 3, fig. 16.

1982 Siphogonuchites triangulatus; Luo et al., p. 175, pl. 15, fig. 15.

1982 ex gr. Coleollidae; Voronin et al., p. 64, pl. 7, figs. 3,4 .

1982 ?Conularis absidates Jiang in Luo et al., 1982, p. 174, pl. 15, figs. 7, 8.

1982 Lopochites letazonalis [sic]; Luo et al., p. 176, pl. 15, fig. 18.

1982 Palaeosulcachites biformis; Luo et al., p. 175, pl. 15, fig. 16.

1982 Palaeosulcachites biformis; Voronin et al., p. 64, pl. 7, figs. 5-11.

1982 Palaeosulcachites irregularis; Luo et al., p. 175, pl. 15, fig. 17.

1982 Trapezochites chordoides; He and Yang, pl. 3, figs. 13, 18, 20.

1982 Trapezochites chordoides; Luo et al., p. 176, pl. 15, fig. 19.

1984 Palaeosulcachites biformis; Luo et al., pl. 11, fig. 6.

1984 Siphogonuchites triangulatus; Luo et al., pl. 11, figs. 3,4 .

1984 Siphogonuchites pusilliformis; Qian, pl. 2, figs. 11-13.

1984 Siphogonuchites triangularis; Qian, p. 88, pl. 2, figs. 1-4.

1984 Siphogonuchites equilateralis Qian and Yin; Wang et al., pl. 4, fig. 6.

1984 Siphogonuchites bisulcatus Qian and Yin; Wang et al., pl. 4, figs. 13, 14.

1984 Palaeosulcachites irregularis; Qian, pl. 2, figs. 7-10, 21-22.

1984 Palaeosulcachites minus Qian, 1984, p. 88, pl. 2, figs. 17-20; pl. 3, figs. 18, 20.

1984 Palaeosulcachites minus; Qian and Yin, p. 107, pl. 3, fig. 1; ?pl. 4, figs. 1, 2.

1984 Palaeosulcachites minus; Wang et al., pl. 4, figs. 1, 15, 19.

1984 Palaeosulcachites shipaiensis; Qian, 1984, pl. 2, figs. 5, 6 .

1984 Palaeosulcachites shipaiensis; Xing et al., pl. 21, fig. 14. 


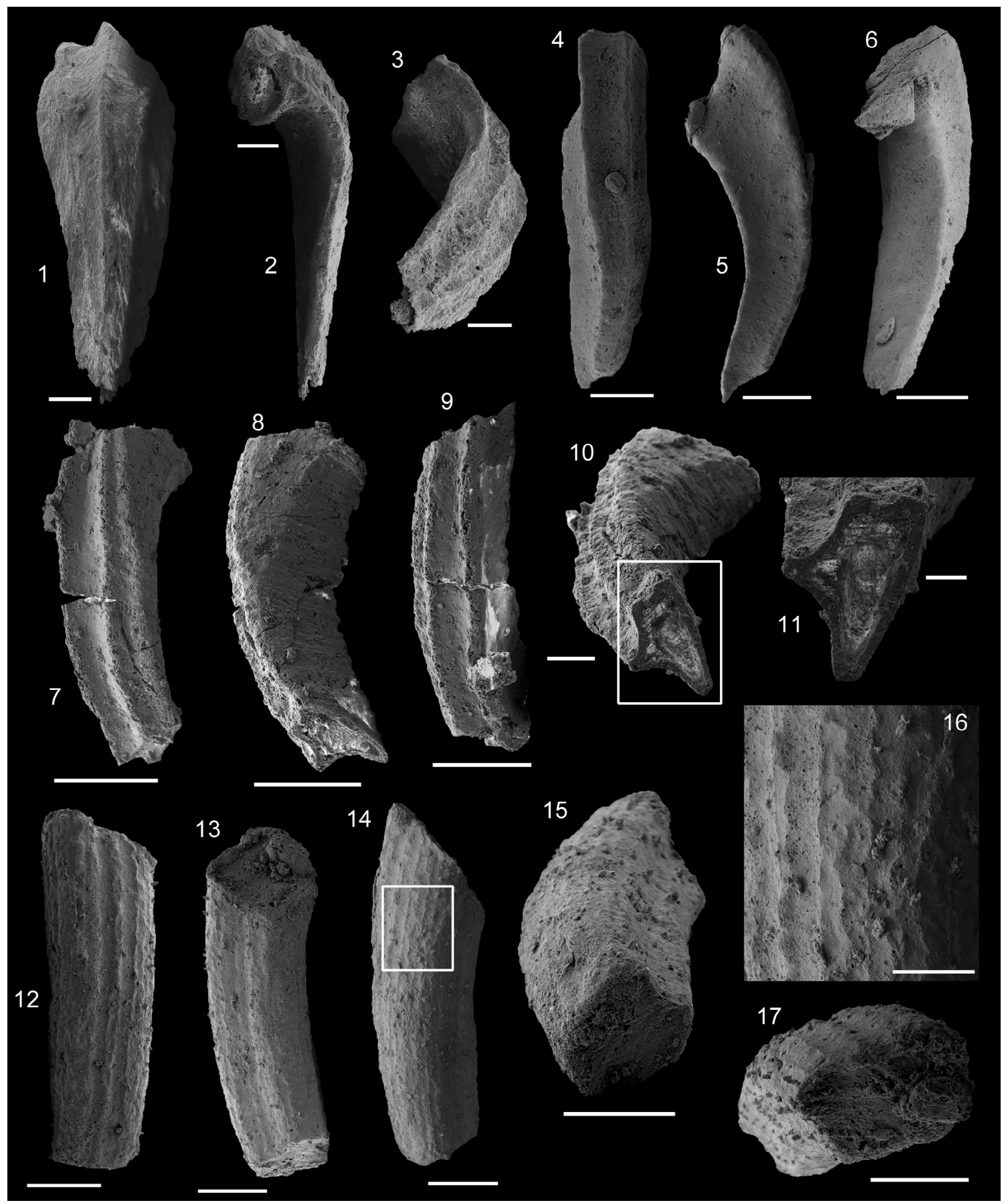

FIGURE 9. 1-11. Siphogonuchites triangularis Qian, 1977. 1-3. USTL1254/23: 1. Dorsal view; 2. Lateral view; 3. Distal view. 4-6. USTL1227/4: 4. Dorsal view; 5. Lateral view; 6. Ventral view. 7-11. USTL1255/9: 7. Dorsal view; 8. Ventral view; 9. Lateral view; 10. Distal view, square shows location of 11; 11. Detail of cross-section. 12-17. Lomasulcachites macrus Qian and Jiang, 1980; USTL1244/4: 12. View of the sulcus; 13. Lateral view; 14. Lateral view, square shows location of 16; 15. Distal view with cross section; 16. Details of ornamentations; 17. Proximal view with cross-section. Scale bars equal: 1, 2, 3, 11, $100 \mu \mathrm{m} ; 10,16,200 \mu \mathrm{m} ; 4-9,12-15,17,500 \mu \mathrm{m}$. 
1988 Halkieria sp. 3; Kerber, 1988: 163, text-fig. 14, pl. 5, figs. 19-24.

1989 Palaeosulcachites biformis; Qian, p. 200, text-figs. 41, 42; pl. 40, figs.5, 6, 8-13; pl. 41 , figs. $1-16$; pl. 42, figs. 1-4, 9-16, ?17, 18, 19; pl. 47, fig. 7; pl. 90, figs. 4-6; pl. 91, figs. 2-6; pl. 92, figs. 3-4.

1989 Siphogonuchites triangularis; Qian, p.198, pl. 40 , figs. $1-4,7,14-16$; pl. 42 , fig. 5 ; pl. 47, fig. 6; pl. 90, fig. 7; pl. 91, figs. 1, 7, 8.

1989 Siphogonuchites triangularis; Qian and Bengtson, p.21, text-figs. 7-11.

1990 Siphogonuchites aff. triangularis; Khomentovsky et al., p.34, pl. 8, fig. 6 .

1990 ?Siphogonuchites sp.; Khomentovsky et al., p. 34, pl. 8, fig. 7 .

1996 Siphogonuchites triangularis; Esakova and Zhegallo, p. 139, pl. 11, figs. 1-18.

2004 Siphogonuchites triangularis; Steiner et al., figs. 3.5, 7, 8.5.

Material. About 30 incomplete phosphatised/phosphatic sclerites infilled with phosphatic material including illustrated specimens USTL1227/4, USTL1254/23, and USTL1255/9.

Distribution. Section $\mathrm{K} 2$, samples $\mathrm{K} 2 / 3 \mathrm{~b}, \mathrm{~K} 2 /_{4 \mathrm{~b}}$, $\mathrm{K} 2 /_{6}, \mathrm{~K} 2 /_{8 \mathrm{a}}, \mathrm{K} 2 /{ }_{9 \mathrm{a}}, \mathrm{K} 2 /{ }_{10 \mathrm{a}}, \mathrm{K} 2 /{ }_{12 \mathrm{~m}}, \mathrm{~K} 2 /{ }_{120}, \mathrm{~K} 2 /{ }_{12 \mathrm{~s}}$, $\mathrm{K} 2 /{ }_{13}$, and $\mathrm{K} 2 /{ }_{14}$; section $\mathrm{K} 3$, samples $\mathrm{K} 3 \mathrm{~T} / 2 \mathrm{c}$, K3T/ $3 a, \mathrm{~K} 3 \mathrm{~T} / 4 \mathrm{a}, \mathrm{K} 3 \mathrm{~B} / 12$, and $\mathrm{K} 3 \mathrm{~B} /{ }_{13}$; section $\mathrm{K} 4$, samples $\mathrm{K} 4 /_{4 \mathrm{a}}, \mathrm{K} 4 /_{4 \mathrm{~b}}, \mathrm{~K} 4 /_{11}$, and $\mathrm{K} 4 /_{17}$; section $\mathrm{K} 5$, samples $\mathrm{K} 5 /_{2}, \mathrm{~K} 5 /_{3}, \mathrm{~K} 5 \mathrm{~b} / 2, \mathrm{~K} 5 \mathrm{~b} / 3, \mathrm{~K} 5 \mathrm{~b} / 4, \mathrm{~K} 5 \mathrm{~b} / 8, \mathrm{~K} 5 /$ ${ }_{13}, \mathrm{~K} 5 /{ }_{19}, \mathrm{~K} 5 /_{25}, \mathrm{~K} 5 /_{32}, \mathrm{~K} 5 /_{35}, \mathrm{~K} 5 /_{39}$, and $\mathrm{K} 5 / 40$.

Description. Scale-like elongate sclerites are variably flattened, with a distal flattening in a plane perpendicular to that of the proximal flattening (corresponding to the plane of elongation of the aperture; Figure 9.2). Distal flattening defines a flat to slightly concave, smooth lower side (Figure 9.2, $9.6,9.8$ ) and a more complex, upper, longitudinally ridged side which gives to the plate a trapezoidal transverse section (Figure 9.10-11). The lower and upper sides are clearly separated by sharp edges (Figure 9.2-3, 9.5-6). The sclerites are longitudinally curved toward the lower side with a stronger curvature close to the proximal end (Figure 9.2). They range from approximately $500 \mu \mathrm{m}$ to more than $2 \mathrm{~mm}$ in length and $100 \mu \mathrm{m}$ to $1 \mathrm{~mm}$ in maximum width (about the middle part of the sclerites); hence, the sclerites are twice to three times longer than wide. The sclerites taper distally (Figure 9.1, 9.4-5). The apex is not preserved in some specimens (Figure 9.7-11) but, when present, it is rounded to acute (Figure 9.1, 9.4). The basal (proximal) foramen is generally elongate along proximaldistal axis (Figure 9.2). The foramen can be polygonal to rounded in shape (Figure 9.2) according to the general section of the plate. The sclerites always taper proximally to the base, which can also be slightly constricted (Figure 9.1). The upper side carries 2 to 3 main prominent longitudinal ridges which are more pronounced in the proximal part and attenuate distally (Figure 9.1, 9.4, 9.7). Those ridges delimit wide but relatively shallow longitudinal, concave (Figure 9.3) to rarely flat furrows (Figure 9.4). Fine structure of the sclerite is generally poorly preserved, but most specimens exhibit fine transverse lines on upper and even, if less pronounced, on lower side (Figure 9.2, 9.10).

Remarks. The genus is considered here as monospecific because the other species $S$. pusilliformis and S. intermedius Qian, 1977 are regarded, in this study, as a junior synonym of $S$. triangularis. Indeed, the differentiation of both species from $S$. triangularis relies on the absence of ornamentation on the upper side of $S$. pusilliformis but this absence is most probably due to poor preservation. In addition, the morphological types usually referred to $S$. pusilliformis are included in the variability exposed by the large $S$. triangularis assemblage described by Qian and Bengtson (1989).

Other occurrences. China, $S$. triangularis has a long Nemakit-Daldynian to Tommotian range from the Anabarites trisulcatus-Protohertzina anabarica Zone to the Watsonella-crosbyi Zone (Steiner et al., 2007); Zhongyicun Member of the Zhujiaqing Formation, Nemakit Daldynian (Paragloborilus subglobosus-Purella squamulosa Zone), Xianfeng and Baizai, Xundian County (Qian, 1989; Qian and Bengtson, 1989), Shangsuan, Jinning County (Qian, 1989; Qian and Bengtson, 1989) and Dahai, Huize County (Luo et al., 1982), Yunnan province; Zhongyicun Member and Dahai Member, Zhujiaqing Formation, Nemakit Daldynian to Tommotian (Paragloborilus subglobosus-Purella squamulosa Zone to Watsonella crosbyi Zone), at Meishucun and Wangjiawan, Jinning County (Jiang, 1980b; He and Yang, 1982; Luo et al., 1984; Qian and Bengtson, 1989) and Xiaotan, Yongshan County (Li and Xiao, 2004), Yunnan Province; Maidiping Formation, Tommotian (Paragloborilus subglobosus-Purella squamulosa Zone), Maidiping, Emei County, Sichuan Province (Xing et al., 1984); Kuanchuanpu Formation, Nemakit Daldynian (Anabarites trisulcatus-Protohertzina anabarica Zone to Paragloborilus subglobosus-Purella squamulosa Zone), Kuanchanpu, Shizhinggou and Yuanjiaping, 
Ningqiang County, Shaanxi Province (Xing et al., 1984; Steiner et al., 2004) and Shatan, Nanjiang County, Sichuan Province (Steiner et al., 2004); Gezhongwu Member, Dengying Formation, Nemakit Daldynian to Tommotian (Paragloborilus subglobosus-Purella squamulosa and Watsonella crosbyi zones), Damachang, Gezhongwu, and Wuzhishan, Zhijin County, Guizhou Province (Qian and Yin, 1984; Xing et al., 1984); Xinli Member of Dengying Formation, Tommotian, at Xinli, Nanjiang County, Sichuan Province (Steiner et al., 2004); Upper bed of the Huangshandong Formation, Nemakit Daldynian to Tommotian (Paragloborilus subglobosus-Purella squamulosa and Watsonella crosbyi zones), Tianzhushan, Shibei and Yangjiadun, Hubei Province (Qian et al., 1979).

Occurrences out of China: Bayan-Gol Formation, Nemakit-Daldynian (Anabarites trisulcatus Zone to Anabarella plana Zone), Khasagt-Khairkhan Range, Salaany-Gol, Bayan-Gol, and Orolgay-Gol, Mongolia (Voronin et al., 1982; Esakova and Zhegallo, 1996); Pestrotsvet Formation, Tommotian (Nochoroicyathus sunnaginicus Zone), Selinde River near Mar-Kyuyel, Siberian Platform, Russian Federation (Khomenthovsky and Karlova, 1993); Member III, Ust-Yudoma Formation, Nemakit-Daldynian (Purella antiqua Zone), Malyi Chaydakh (Mount Konus), Siberian Platform, Russian Federation (Khomenthovsky and Karlova, 1993).

Genus LOMASULCACHITES Qian and Jiang in Jiang, 1980.

1980a Lomasulcachites Qian and Jiang in Jiang 1980b, p. 91.

1982 Lomasulcachites; Luo et al., p.176.

1989 Lomasulcachites; Qian and Bengtson, p. 36, text-figs. 20, 21.

1989 Lomasulcachites; Qian, p. 210.

Type species. Lomasulcachites macrus Qian and Jiang in Jiang, 1980, Tommotian (Watsonella crosbyi Zone), Meishucun, Jinning County, Yunnan Province, China.

Diagnosis. See Qian and Bengtson (1989).

Lomasulcachites macrus Qian and Jiang in Jiang, 1980

Figure 9.12-17

1980b Lomasulcachites macrus Qian and Jiang in Jiang, 1980b, pl. 3, figs. 6, 8.

1982 Heterosculpotheca phaneres Jiang in Luo et al., 1982, p. 167, pl. 13, figs. 23-25.

1982 Lomasulcachites macnus [sic]; Luo et al., p. 176, pl. 16, figs. $1,2$.
1982 Lomasulcachites macrus; He and Yang, pl. 3, fig. 17.

1984 Heterosculpotheca phaneres; Jiang, pl. 2, fig. 8 [sic].

1984 Siphogonuchites spinatus Yue in Xing et al., 1984, p.175, pl. 27, fig. 30.

1988 Halkieria sp. 3; Kerber 1988, p.163, pl. 5, figs. 25-27, ?28, 29-30, non text-fig. 14, pl. 5, figs. 19-24 [recte Siphogonuchites triangularis].

1989 Heterosculpotheca phaneres; Qian, p. 79, text-fig. 14 , pl. 11 , figs. $1-12$, pl. 79 , figs. 1-3.

1989 Lomasulcachites macrus; Qian, p. 210, pl. 11 , figs. $13-17$; pl. 12 , figs. $12-8$; pl. 45 , fig. 5; pl. 47, figs. 3-5.

1989 Lomasulcachites macrus; Qian and Bengtson, p. 36 , text-figs. $20,21$.

Material. 3 phosphatised/phosphatic sclerites including USTL1244/4.

Distribution. Section 2, sample K2/12s; Section 3, sample $\mathrm{K} 3 \mathrm{~T} / 2 \mathrm{e}$; Section 5 , samples $\mathrm{K} 5 / 39$ and $\mathrm{K} 5$ / 45 .

Description. The horn-shaped, slender sclerites are straight to slightly curved. The transverse section is irregularly rounded to trapezoidal in shape (Figure 9.13, 9.15, 9.17), due to the organisation of the facets varying in width and shape. Almost all facets are flat to slightly convex. Only one, strongly concave, forms a sulcus running through the entire sclerite length (Figure 9.13, 9.15, 9.17). More or less distinct longitudinal ridges run along the surface of the internal molds (Figure 9.12-14, 9.16). The ridges are more pronounced and spaced on the convex surface than on the internal mold (Figure 9.12). Few transverse striations, hardly identified, locally give to the surface an irregular pattern (Figure 9.16).

Other occurrences. Yunnan Province of China: Zhongyicun Member of the Zhujiaqing Formation, Nemakit-Daldynian (Yunnanotheca-Siphogonuchites Zone equivalent to the Paragloborilus subglobosus-Purella squamulosa Zone; Qian, 1989), Xianfeng, Xundian County (Qian, 1989; Qian and Bengtson, 1989), Shangsuan and Meishucun, Jinning County, (Jiang, 1980b; He and Yang, 1982); Zhongyicun Member and Dahai Member, Zhujiaqing Formation, Nemakit-Daldynian to Tommotian (Paragloborilus subglobosus-Purella squamulosa Zone and Watsonella crosbyi Zone; Luo et al., 1982), Yulu and Dahai, Huize County (Qian, 1989). 
?Class POLYPLACOPHORA de Blainville, 1816 Order and Family uncertain

Genus OCRURANUS Liu, 1979

1979 Ocruranus Liu, 1979, p. 506.

1980a Pileconus Jiang, 1980a, p. 119.

1980a Postephaconus Jiang, 1980a, p. 119.

1980a Stephaconus Jiang, 1980a, p. 117.

1980a Stoliconus Jiang, 1980a, p. 116.

1982 Chengjiangoconus $\mathrm{He}$ and Yang, 1982, p. 87.

1982 Eohalobia Luo et al., 1982, p. 194.

1984 Dengyingoconus Chen and Xiong in Xing et al., 1984, p. 163.

1984 Hanshuiella Yue in Xing et al., 1984, p. 168.

1987 Liorichita Liu, 1987, p. 386-387.

1987b Meishucunchiton Yu, 1987b, p. 110-111.

1987b Postephaconus Jiang, 1980; Yu 1987b: 113-114.

1987b Runnegarochiton Yu gen. nov.; Yu 1987b: 107-108.

1987b Stoliconus Jiang, 1980; Yu 1987b: 116.

2007 Ocruranus; Conway Morris and Caron, p. 1258.

2009 Ocruranus; Vendrasco et al., p. 1388 1392.

2010 Ocruranus; Parkhaev and Demidenko, p. 979.

Type species. Ocruranus finial Liu, 1979, Nemakit-Daldynian (Anabarites trisulcatus-Protohertzina anabarica Zone to Paragloborilus subglobosus-Purella squamulosa Zone), Dadiyakou, Chengjiang County, Yunnan Province, China.

Diagnosis. See Vendrasco et al. (2009).

Remarks. The genus Ocruranus Liu, 1979 usually refers to a type of rounded plate with prominent, lowered subapical shelf. However, it turned out that this name was applied to sclerites belonging to scleritome-bearing organisms constituted of several plates (part-based taxonomy). Several lines of evidence pointed out that Ocruranus, Eohalobia Luo et al., 1982 and plates attributed to the genus Gotlandochiton? by Yu (1987b) were part of a same scleritome: (1) Ocruranus and Eohalobia sclerites are morphologically similar (smooth shells with a recessed subapical shelf or folded reentrant, a highly arched shell with jugal angle of $c$. 90-120 degrees and a similar bulbous apex; Vendrasco et al., 2009); (2) they share the same micro- structure (layers of fibrous elements; Vendrasco et al., 2009); (3) the sclerites co-occur almost at every locality they have been described (Vendrasco et al., 2009; Parkhaev and Demidenko, 2010). Therefore, following Vendrasco et al. (2009), Eohalobia has been grouped with Ocruranus.

\section{Ocruranus cf. subpentaedrus (Jiang, 1980)} Figure 10.1-9

Material. 9 phosphatic internal molds of tail sclerites (sensu Vendrasco et al., 2009) including illustrated specimens USTL1228/5 and USTL1251/1.

Distribution. Section $\mathrm{K} 2$, sample $\mathrm{K} 2 /_{3 \mathrm{~b}}$; section $\mathrm{K} 3$, samples $\mathrm{K} 3 \mathrm{~T} / 4 \mathrm{a}, \mathrm{K} 3 \mathrm{~T} / 6$, and $\mathrm{K} 3 \mathrm{~B} / 6$; section $\mathrm{K} 4$, samples $K 4 / 7$ and $K 4 /{ }_{11}$; section $K 5$, samples $K 5 /$ ${ }_{12}, \mathrm{~K} 5 / 17$, and $\mathrm{K} 5 / 32$.

Description. The plates are bilaterally symmetrical, low cap-shaped, up to $2680 \mu \mathrm{m}$ long, $2130 \mu \mathrm{m}$ wide, and $1280 \mu \mathrm{m}$ high (width/length ratio about $1 /$ 2; height/length ratio about 4/5), with a rounded posterior margin (sensu Vendrasco et al., 2009) and straight to angular anterior margin (Figure $10.1,10.7)$. The apex is eccentric to submarginal and located on the symmetry axis (Figure 10.1, 10.7). It is blunt and slightly projecting or bent toward the anterior margin (Figure 10.4, 10.8). The apex is slightly lowered and separated from dorsal field by variably steep folds. The two folds converge to the apex (Figure 10.1, 10.7). The subapical field is slightly lowered compared with the apex and dorsal field. It is constituted by a prominent, convex shelf, making a vertical sinus in anterior view (Figure 10.3-4). Its median curvature may be simply angular or form a median triangular elevation bordered by two lateral broad furrows (Figure 10.9). Its anterior margin is straight or angular, in this case divided into two symmetrical segments diverging from the apex (emargination; Figure $10.1,10.7)$. The anterior margin is slightly upfolded in some specimens (Figure 10.3). Imprints of the shell structure are present on the external surface of the internal mold (Figure 10.6). They consist of parallel striations running from the apex toward the margin and may represent a layer of fibrous elements similar to a lamello-fibrillar shell ultrastructure.

Comparisons. The material described herein exhibits the diagnostic features of Ocruranus, including the elliptical outer shape, the lowered, projecting subapical field and fibrous shell layer. As noticed by Vendrasco et al. (2009), O. finial and $O$. supentaedrus can be distinguished by 1) the subapical field that projects the maximum at the midline in $O$. finial but is straight to emarginate in $O$. 


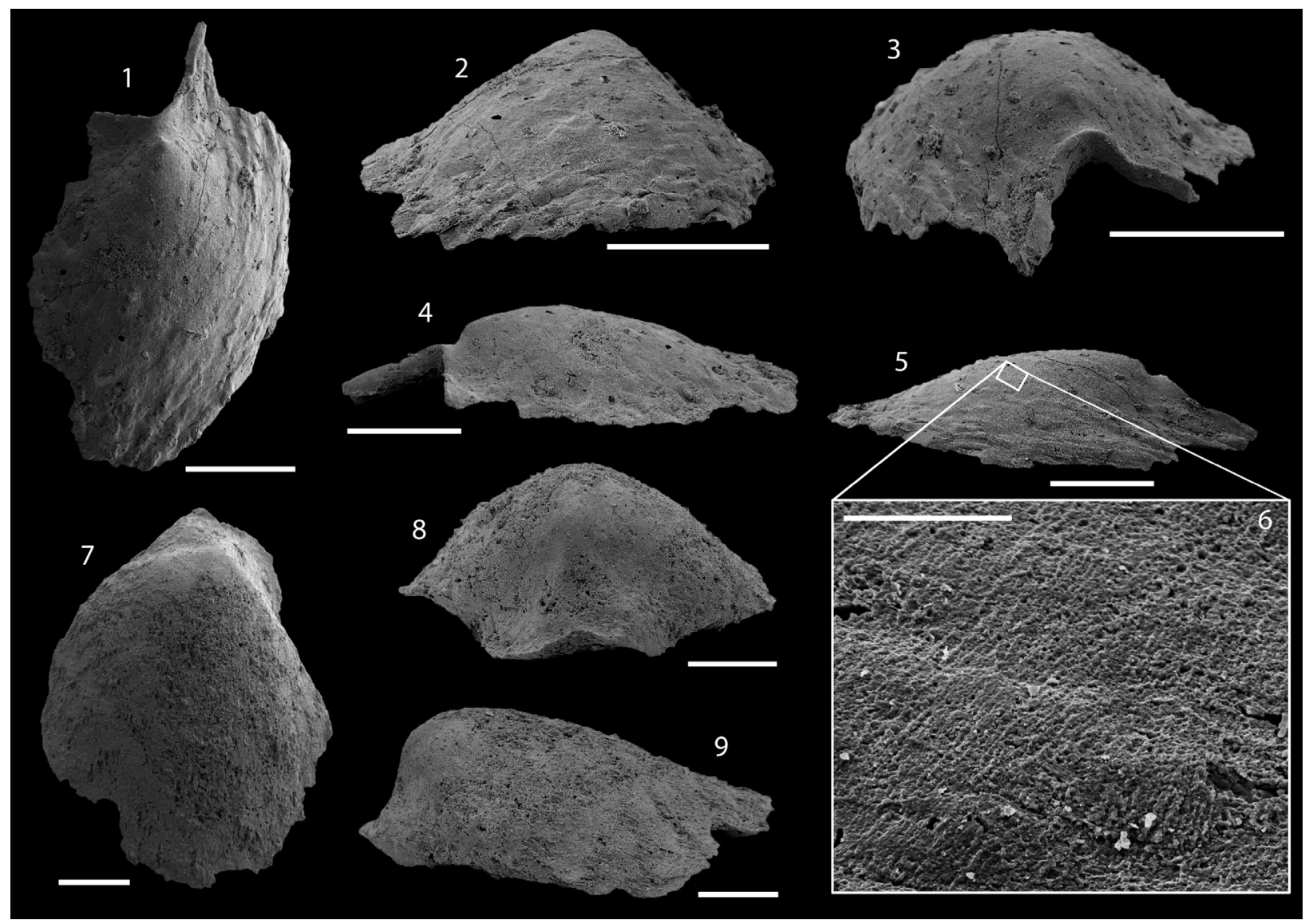

FIGURE 10. Ocruranus cf. subpentaedrus (Jiang, 1980). 1-6 USTL1228/5: 1. Upper view; 2. Posterior view; 3. Anterior view; 4. Left lateral view; 5 . Right lateral view, square shows location of $6 ; 6$. Detail of parallel striations on external surface of internal molds. 7-9. USTL1251/1: 7. Upper view; 8. Anterior view; 9. Left lateral view. Scale bars equal: $6,50 \mu \mathrm{m}$ and1-5, 6-9, $500 \mu \mathrm{m}$.

subpentaedrus, and 2) the upfolded anterior margin (re-entrant) which is more pronouced in O. subpentaedrus.

Tail plates described herein resemble $O$. finial by their gross morphology, their length exceeding their width, and the folded subapical shelf, and poorly developed re-entrant. However, it is different from $O$. finial and closer to $O$. subpentaedrus by the lateral segments of the anterior margin, which diverge from the apex (emargination sensu Vendrasco et al., 2009). However, the variability in Ocruranus is great both within and between species and few specimens are available from the studied assemblage. Therefore, we putatively assign the new specimen from Montagne-Noire to $O$. cf. subpentaedrus, keeping in mind that these plates may represent a new undescribed species.

Remarks. The present material is only constituted of tail valves and no intermediate and head valves are known. However, this situation has previously been encountered in Mongolia and Greenland
(Voronin et al., 1982, Peel and Skovsted, 2005). This absence is probably due to biostratinomic bias.

Although this paper agrees with the assignment of Ocruranus to the ?Polyplacophora proposed by Vendrasco et al. (2009), their observation that Ocruranus could not be an Halkieriid-like animal because it never co-occurs with halkieriids in any known section is not supported by the present study. In some (but not every) herein studied samples, Ocruranus co-occurs with Halkieria and Siphogonuchites sclerites. Parkhaev and Demidenko (2010) also noted the co-occurrence of halkieriids and Ocruranus.

Other occurrences. Yunnan Province, China: Zhongyicun Member and Dahai Member, Zhujiaqing Formation, Nemakit Daldynian to Tommotian (Paragloborilus subglobosus-Purella squamulosa Zone to Watsonella crosbyi Zone), Meishucun (Jiang, 1980a; Luo et al., 1984; Yu, 1987b; Vendrasco et al., 2009; Parkhaev and Demidenko, 
2010) and Zhongyicun Member, Zhujiaqing Formation, Nemakit Daldynian (Paragloborilus subglobosus-Purella squamulosa Zone), Shangsuan (Yu, 1987b) Jinning County and Xianfeng and Baizai, Xundian County (Yu, 1987b).

\section{Class and Order uncertain}

Family MAIKHANELLIDAE Missarzhevsky, 1989

Discussion. The family Maikhanellidae is considered to belong to the phylum Mollusca, as suggested by Feng and Sun (2003), Ponder et al. (2007) and Parkhaev and Demidenko (2010). The herein studied internal molds of maikhanellids exhibit polygonal structures that replicate the prismatic shell layer typical of molluscs. However, no palaeobiological information is further avalaible, preventing any additional investigation of their supra-familial classification and affinities among molluscs.

Genus PURELLA Missarzhevsky, 1974

1974 Purella Missarzhevsky, 1974, p. 184.

1981 Rozanoviella Missarzhevsky, 1981, p.27.

1988 Maikhanella (Zhegallo in Voronin et al.); Kerber 1988, p. 179.

1988 Rozanoviella; Kerber 1988, p. 176.

1989 Purella; Missarzhevsky, p. 174.

1989 Purella; Qian and Bengtson, p. 97.

1996 Purella; Esakova and Zhegallo, p. 161.

1996 Rozanoviella; Esakova and Zhegallo, p. 164.

2001 Maikhanella; Feng et al., p. 206.

2007 Maikhanella; Ponder et al., p. 137.

2007 Purella; Ponder et al., p. 137.

2010 Purella; Parkhaev and Demidenko, p. 994. Type species. Purella cristata Missarzhevsky, 1974, Tommotian (Nochoroicyathus sunnaginicus Zone), Zrueachaka River near Nemakit-Daldyn River mouth, Siberia, Russian Federation.

Emended diagnosis. Shell with slightly elongate aperture and height somewhat shorter than or equal to length of aperture; apex shifted to the proximal margin; shell profile of proximal side slightly concave; distal side convex with slight ridge along sagittal line. Surface of the shell corresponding to comarginal elongated scales (emended from Qian and Bengtson, 1989).

Remarks. Following Qian and Bengtson (1989), the terminology used below is based on the eccentrical apex. The area and margin close to the apex will be referred to as proximal and opposite parts as distal.

Purella gracilis (Zhegallo in Voronin et al., 1982) Figure 11.1-19

1982 Tanuella gracilis Zhegallo in Voronin et al., 1982, p. 42, pl. 1, figs. 12-13.

1988 Rozanoviella gracilis (Zhegallo); Kerber, p. 176, 177, pl. 8, figs. 12-16.

1996 Tanuella gracilis; Esakova and Zhegallo, p. 154, 155, pl. XVIII, fig. 4.

Material. About 20 phosphatic internal molds on which fragments of external molds are occasionally found, including USTL1211/5, USTL1213/6, USTL1243/5, and USTL1244/3.

Distribution. Section $\mathrm{K} 2$, samples $\mathrm{K} 2 / 3 \mathrm{~m}$ and $\mathrm{K} 2 / 6$; section $\mathrm{K} 3$, samples $\mathrm{K} 3 \mathrm{~T} / \mathrm{2e}_{\mathrm{e}}$ and $\mathrm{K} 3 \mathrm{~T} / 3 \mathrm{a}$; Section 4 , sample $\mathrm{K} 4 / 2$.

Description. The internal mold of the conch is relatively high cap-shaped, up to $1900 \mu \mathrm{m}$ long, 1050 $\mu \mathrm{m}$ wide, and $1300 \mu \mathrm{m}$ high (height/length ratio from $1 / 2$ to $3 / 4$ ). The aperture is subelliptical (Figure 11.1) with the distal part much wider and rounded than the proximal, variably acute part. The apex lies in the plane of symmetry. It is strongly shifted to the proximal end (Figure 11.2-3, 11.6, 11.15-16) and occassionally even overhangs the apertural margin (Figure 11.9-10). Apex is rounded (Figure 11.3, 11.16) to acute (Figure 11.6, 11.10). The proximal field (between the apex and the proximal margin) is concave to straight in lateral view (Figure 11.2-3, 11.6, 11.15-16). The proximal apertural margin is more or less retracted toward the interior in a sinus (Figure 11.4, 11.11, 11.15). A slight median, longitudinal distal-buttress is visible in some specimens, from apex to proximal margin (Figure 11.17). The lateral fields are convex from the apex to $1 / 4$ of their height and become straight to the apertural margin. The distal dorsal field (from apex to distal apertural margin) is slightly convex (Figure 11.2-3, 11.6, 11.15-16). A well-developed and wide ridge, made of two furrows bordering a fold, is present on the distal field. This structure widens from the apex to the distal margin (Figure $11.1,11.8,11.12,11.14$ ).

The external mold consists of a thick layer of phosphate organised into long, coalescent, comarginal scales which can be separated/pierced by long and sharp slits (about $200 \mu \mathrm{m}$ long and $20 \mu \mathrm{m}$ wide), and arranged into a staggered pattern (Figure 11.2-3, 11.10, 11.15). The scales and slits become shorter and higher in the proximal field, where they are not strictly comarginal but make an angle toward the apex, getting a triangular to trape- 


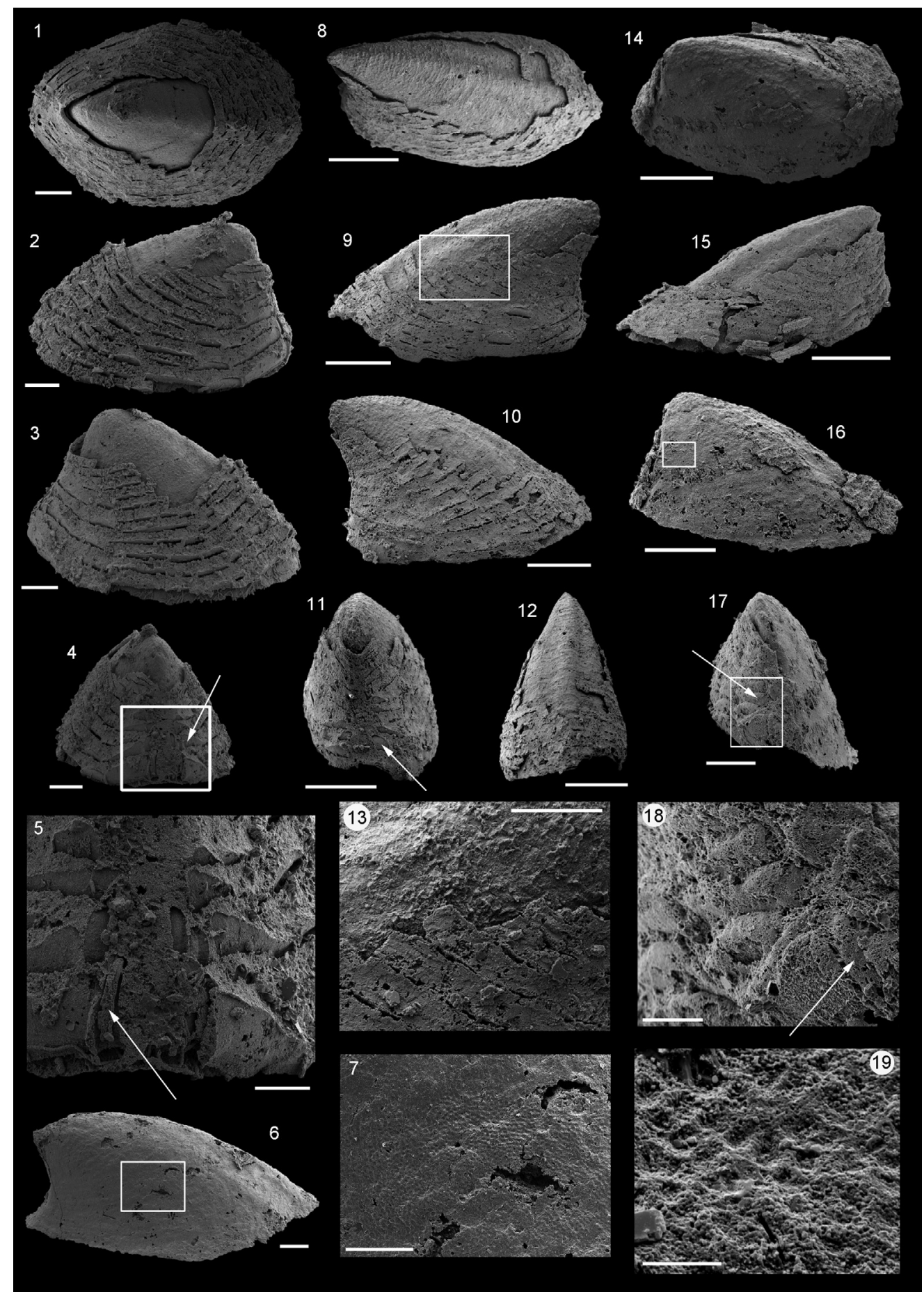

FIGURE 11. Purella gracilis Zhegallo, 1982. 1-5 USTL1211/5: 1. Upper view of internal mold with external coating; 2 , 3. Lateral views; 4. Proximal view, square shows location of 5 and arrow spiny scales that are symmetrically arranged on both sides of the subapical field; 5 . Detail of external coating, arrow points spiny scale. 6-7. USTL1213/6: 6. Lateral view of internal mold, square shows location of 7; 7. Detail of polygonal imprints on lateral fields. 8-13. USTL1243/5: 8. Upper-lateral view of internal mold with external coating; 9. Lateral view, square shows location of 13; 10 . Lateral view; 11. Proximal view, arrow shows subapical spiny scales; 12. Distal view showing median, longitudinal buttress; 13. Detail of internal mold and scaly external coating. 14-19. USTL1244/3: 14. Upper-lateral view; 15 . lateral view, external coating continuously scaly (no slits); 16. Lateral view, square shows location of 19; 17 . Proximal view, square shows location of 18; 18 . Detail of subapical external coating, arrow points spiny scale; 19 . Detail of polygonal imprints on internal mold. Scale bars equal: 19, $20 \mu \mathrm{m} ; 5,7,18,100 \mu \mathrm{m} ; 1-4,13,200 \mu \mathrm{m} ; 17,300 \mu \mathrm{m} ; 6,8-12,14-16,500 \mu \mathrm{m}$. 
zoidal shape (Figure 11.4, 11.11, 11.17-18). They are more loosely spaced and no longer coalescent (Figure 11.4-5, 11.11, 11.17-18). Two rows of spiny scales are symmetrically arranged on both sides of the posterior field (arrowed in Figure 11.5, $11.11,11.18$ ). Those spiny scales are hollow as seen in Figure 11.5, where the internal mold of the spine is visible.

The presence of both internal and external molds allows interpolations of shell characters. According to the space between internal and external molds (Figure 11.1, 11.3, 11.8, 11.17), the shell might be relatively thick and even thicker in the proximal area (Figure 11.3, 11.11). Buttresses are present on both internal molds and external coating, whereas the scale arrangement of the shell is just underlined on internal molds by faint comarginal arrays of granules, occassionally bound together to form comarginal ribs (Figure 11.1-3). Polygonal imprints (about $10 \mu \mathrm{m}$ in diameter) are present on the internal mold, particularly on lateral fields (Figure 11.6-7, 11.19). Further specimens could belong to this species but are preserved only as internal molds; hence, their taxonomic assignment is doubtful.

Remarks. The species is herein reassigned to the genus Purella Missarzhevsky, 1974 because it clearly differs from Tannuella, which is characterised by the presence of apical septation and the central position of the apex and those diagnostic features of Tannuella are absent from Purella gracilis. The species belongs to the genus Purella because its subelliptical shape corresponds to the shape of Purella species. Moreover, the apex is shifted to the proximal margin, the subapical proximal field is slightly concave and the distal field is convex and ornamented with a slight ridge along the sagittal line as in Purella species. Finally, the external coating reveals that the shell of $P$. gracilis is constituted of comarginal elongated scales similar to Purella species scales.

The French specimens of $P$. gracilis exhibit a shell ultrastructure typical of Purella on the distal and lateral fields but similar to Maikhanella in the subapical area. Indeed, on the distal and lateral fields, the shell is constituted of long, coalescent, comarginal scales arranged into a staggered pattern. The scales are fused to each other at their base. However, the present specimens enabled the identification of hollow spiny scales loosely spaced in the subapical area. Those scales are very similar to the sclerites described in Maikhanella by Bengtson (1992).
Comparisons. P. cristata Missarzhevsky, 1974 is characterised by more spaced scales organised into concentric ridges, which differs from $P$. gracilis. $P$. gracilis differs from $P$. arcana Valkov, 1987 in the size and number of scales. Indeed, the scales of $P$. gracilis from the Heraultia Limestone are almost twice the size of $P$. arcana which are $20 \mu \mathrm{m}$ in average width and $100 \mu \mathrm{m}$ in mean length. Therefore, there are twice as many scales in $P$. arcana than in $P$. gracilis. Moreover, $P$. gracilis shows higher L/W ratio (species is narrower and longer) and has a sharper apex quite curved toward the proximal margin that differ from $P$. arcana and $P$. squamulosa. $P$. elegans is only known from internal mould but they are much higher than $P$. gracilis and the apex is more rounded and only slightly marginally shifted. However, P. gracilis, P. arcana, P. squamulosa and $P$. elegans are potentially synonym species of P.cristata as their differences are slightly expressed and could be the result of intraspecific variations. However, the preservation and illustration of the material of P.cristata are too poor to conclude and a reexamination of the Siberian material is necessary. Moreover, $P$. elegans is only known as internal mold and shell material or, at least, external coating is necessary to assess its assignment. In $P$. tenuis Zhegallo in Esakova and Zhegallo, 1996 and P. formosa Zhegallo in Esakova and Zhegallo, 1996, the outer surface of the shell exhibits scales organised into faint continuous concentric ridges, a major difference from the outer shell surface of $P$. gracilis. $P$. antiqua is described as having a surface sculpture consisting of parallel ridges occasionally broken up. In $P$. gracilis, the surface sculpture consists of coalescent and staggered scales. The split openings might correspond to thinner, fragile coating in the area of scale "overlapping" in shell ornamentation.

Other occurences. Sunnagin Member, Pestrotsvet Formation, Tommotian (Nochoroicyathus sunnaginicus Zone), Selinde and Dzhanda rivers, Siberian Platform, Russian Federation (Khomentovsky and Karlova, 1993); Bayan-Gol Formation, Nemakit-Daldynian to Tommotian (Anabarella plana and Watsonella crosbyi zones), Bayan-Gol (Voronin et al., 1982), and Salaany-Gol (Esakova and Zhegallo, 1996), Zhavkhan Province, Mongolia.

Purella layracensis (Kerber, 1988) Figure 12.1-20

1988 Maikhanella layracensis Kerber, 1988, p. 179-181, text-figs. 24-26, pl. 8, figs. 1-7.

Material. About 15 phosphatic internal molds on which fragments of external molds are present 


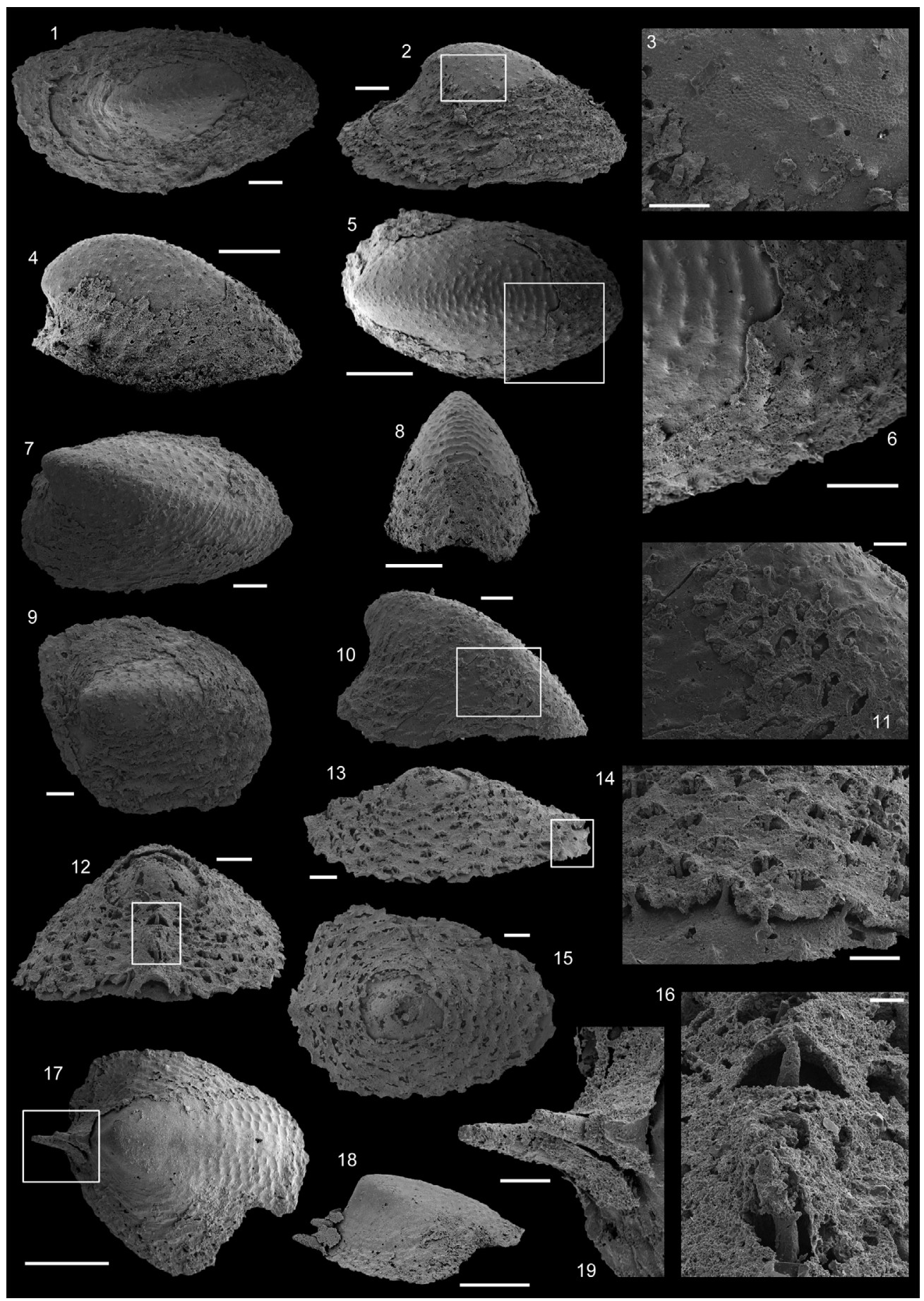

FIGURE 12. Purella layracensis (Kerber, 1988). 1-3. USTL1238/6: 1. Upper view, large subapical shelf; 2. Lateral view, square shows location of 3; 3. Detail of polygonal imprints and granules on the internal mold. 4-6, 8. USTL1253/4: 4. Lateral view; 5 . Upper view, square shows location of 6; 6. Detail of granulated internal mold and scaly external coating; 8. Distal view showing mid-dorsal buttress. 7, 10-11. USTL1235/5: 7. Upper-lateral view; 10. Lateral view, square shows location of $11 ; 11$. Detail of internal mold granules situated in the centre of eye-shaped openings of subtriangular external coating papillae. 9- USTL1233/9, upper view of subrectangular specimen. 12-16. USTL1220/7: 12. Proximal view, square shows location of 16; 13. lateral view, square shows location of $14 ; 14$. Detail of high granules passing through openings of subtriangular papillae; 15. Upper view of low form; 16. Detail of highly-developped internal mold granules. 17-19. USTL1245/1: 17. Upper view of morphotype with subapical spines, square shows location of $19 ; 18$. Lateral view; 19. Detail of subapical spines. Scale bars equal: 16, $20 \mu \mathrm{m} ; 15,50 \mu \mathrm{m} ; 3,11,12,13,15,19,100 \mu \mathrm{m} ; 1$, 2, 6, 9, $200 \mu \mathrm{m} ; 7,10,300 \mu \mathrm{m} ;$ 4, 5, 8, 17, 18, $500 \mu \mathrm{m}$. 
including USTL1220/7, USTL1235/5, USTL1238/6, USTL1245/1, and USTL1253/4.

Distribution. Section K2, samples $K 2 /{ }_{12 s}$; section $\mathrm{K} 3$, samples $\mathrm{K} 3 \mathrm{~B} / 6, \mathrm{~K} 3 \mathrm{~T} / 2 \mathrm{e}$, and $\mathrm{K} 3 \mathrm{~T} / 3 \mathrm{a}$. Section $\mathrm{K} 4$, samples $\mathrm{K} 4 / 9$ and $\mathrm{K} 4 /{ }_{17}$; Section 5 , sample $\mathrm{K} 5 /$ 12 .

Description. The general shape of the internal mold of the conch is highly variable, ranging from very low-conical (height/length ratio of $1 / 3$; Figure 12.13) to relatively high cap-shaped (height/length ration of 5/9; Figure 12.10) and from rounded (width/length ratio of 1 ; Figure 12.15) to laterally compressed (width/length ratio of 1/2; Figure 12.1). The aperture is rounded (Figure 12.9) to oval (Figure 12.1) in outline, and the apertural margin is straight. The apex generally lies in the plane of symmetry (Figure 12.1, 12.5, 12.9, 12.15), but occassionally is slightly displaced toward one side (proximal; Figure 12.7). It is more or less shifted to the proximal end: from almost central (Figure 12.15) to almost overhanging the proximal apertural margin (Figure 12.5, 12.7). The apex is rounded (Figure 12.2, 12.4, 12.10, 12.13). In lateral view, the subapical field (between the apex and the proximal apertural margin) is generally concave (Figure 12.2, 12.4, 12.10) but straight when the conch is very low-conical (Figure 12.13). The lateral fields are gently convex (Figure 12.8-9). The distal dorsal field (from the apex to the distal apertural margin) is convex (Figure 12.2, 12.4, 12.10) or almost straight when the conch is very low-conical (Figure 12.13). A faint buttress made of two shallow furrows bordering a fold is present on the dorsal field (Figure 12.1, 12.5, 12.7-9). Polygonal imprints (about $10 \mu \mathrm{m}$ in diameter) are present on the internal mold, particularly on lateral fields, in the region of the furrows bordering the mid-dorsal buttress (Figure 12.2-3). The external surface of the internal mold also exhibits granules (Figure $12.3,12.11$ ) which are occasionally aligned on the mid-dorsal buttress to form continuous wavy ridges (Figure 12.5-6, 12.8). Those granules are sometimes very high up to columns (Figure 12.13-14, 12.16).

The external mold consists of a thick layer of phosphate bearing subtriangular papillae which can be pierced by eye-shaped openings (from 50 to $200 \mu \mathrm{m}$ long and 25 to $55 \mu \mathrm{m}$ wide; Figure $12.11,12.13,12.16)$. These openings are arranged into concentrical rows (Figure 12.12-14). In one specimen (Figure 12.12, 12.16), the openings are larger, more loosely spaced and aligned along a median row in the subapical area. The papillae and their openings in the external coating coincide with the granules of the internal-mold outer surface (Figure 12.11, 12.13). In the smallest specimen, the granules are highly developed (columns) and reach the outer surface of the external coating (Figure $12.13,12.16)$. They could possibly correspond to pores running through the now missing shell as they enable the communication between the interior (represented by the internal mold) and the exterior (external coating) of the shell. Toward the apex, the granules are less distinct and the apex generally lacks any external coating. The shape of the phosphatic external coating fits the internal mold.

Some specimens exhibit a strong morphological variability, including the presence of projecting spines in the subapical field. Those spines are organised into a row with an increase in size from the apex toward the proximal margin (Figure 12.18-19). In this case, the subapical field is no more concave but flat and exhibits a median buttress for the implantation of the spines (Figure 12.18). The external coating of the specimens bearing spines is only constituted of comarginal rows of papillae with corresponding wavy ridges on the internal mold (Figure 12.17). Those papillae are not opened (Figure 12.5-6; compare with Figure 12.17). The specimens bearing spines are low conical (height/length ratio of 1/2; Figure 12.18), rounded in apical view, and quite small. The variability is also expressed in the shell organisation. One specimen exhibits a very fine external coating made of numerous papillae, which are not opened but aligned along comarginal rows displaced proximally (Figure 12.5-6).

Discussion. The species P. layracensis (Kerber, 1988) was first described under the genus Maikhanella. Indeed, P. layracensis shares with Maikhanella a pattern of scales more or less rhomboidally packed in rows concentric with the shell margin. However, according to the shell fabric of Maikhanella described by Bengtson (1992), the specimens described herein are not regarded as belonging to Maikhanella. Maikhanella exhibits a scaly surface of its shell but the scales penetrate the thickness of the shell and thus may correspond to embedded spicules into an intermediate matrix supposed to be originally organic (Bengtson, 1992). On the contrary, Purella species are characterised by a continuous scaly shell, a character present on all observed specimens. We are, therefore, confident they belong to the genus Purella and the species $P$. layracensis (Kerber, 1988).

Comparison. P. layracensis (Kerber, 1988) differs from all other species of the genus in the shell 

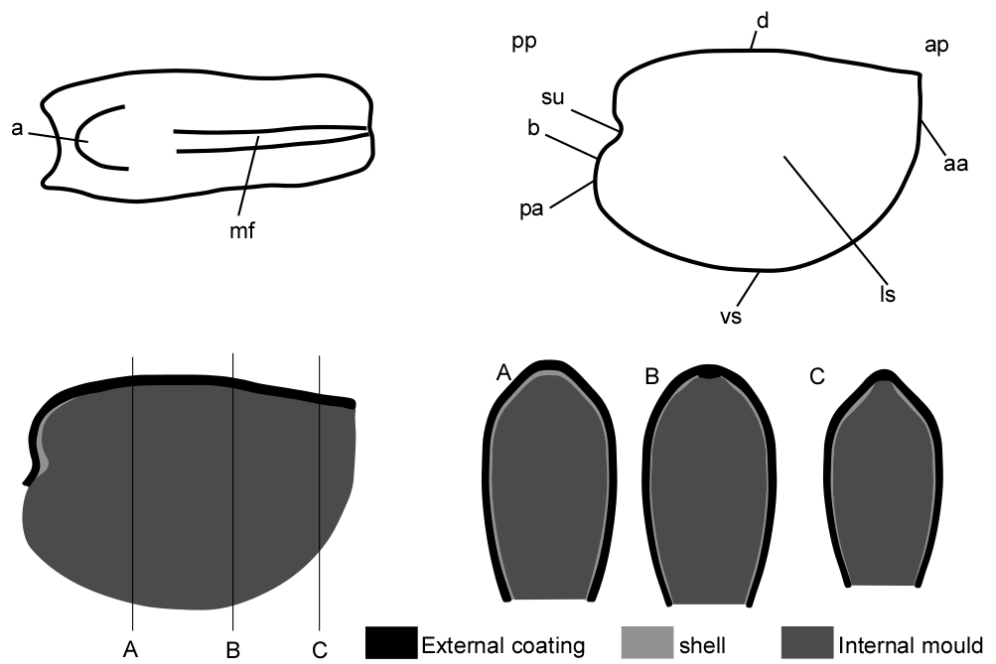

FIGURE 13. Sketch of Watsonella crosbyi Grabau, 1900 highlighting key anatomical features and terms used herein. pp: posterior part; ap: anterior part; d: dorsum; mf: medial dorsal furrow; vs: ventral side; aa: anterior part of the aperture: pa: posterior part of the aperture; a: apex; b: beak; Is: lateral shields; su: subapical shield. Schematic interpretation of internal mold, shell and external coating connections.

organised into rows of papillae and in the presence in certain morphotypes of subapical spines.

Other occurrences. Occurrences of $P$. layracensis (Kerber, 1988) outside of Montagne Noire are not reported.

Class, Order and Family uncertain Genus WATSONELLA Grabau, 1900

1900 Watsonella Grabau, 1900, p. 631.

1935 Heraultia Cobbold, 1935, p. 37.

1974 Heraultia; Missarzhevsky, p. 188.

1974 Heraultia; Runnegar and Pojeta, p. 37.

1976 Heraultia; Runnegar and Jell, p. 1-8.

1976 Heraultipegma Pojeta and Runnegar, p. 54.

1976 Watsonella; Pojeta and Runnegar, p. 55.

1982 Heraultipegma; He and Yang, p. 90.

1988 Watsonella; Kerber, p. 159.

1989 Heraultipegma; Missarzhevsky, p. 187.

1996 Watsonella; Esakova and Zhegallo, p. 171.

2001 Watsonella; Parkhaev, p. 187.

2002 Watsonella; Parkhaev, p. 36.

2011 Watsonella; Li et al., p. 309-319.

Type species. Watsonella crosbyi Grabau, 1900, Tommotian (Late Aldanella attleborensis SSF interval Zone), Sandy Cove and Pleasant Beach of Cohasset, Massachusetts, USA.

Diagnosis. See Li et al. (2011).
Remarks. Watsonella was first considered as a rostroconch by Pojeta et al. (1972) and Pojeta and Runnegar (1976) based on the presence of a possible pegma-like structure. A pegma is a transverse thick plate located under the apex and attached to both valves, dividing the apical area of the shell into anterior and posterior cavities. A sinus, occassionally present in the subapical area of internal molds of Watsonella (Figure 13), was first interpreted to represent such structure, characteristic of the rostroconchs (Pojeta and Runnegar, 1976). This sinus is interpreted here to correspond to a thickening of the shell rather than a plate dividing the internal cavity (Figure 13). In addition, Watsonella lacks the rostroconch typical rostrum (a tube-like structure probably functioning as a siphon supplying water to the gills). The supra-generic classification of Watsonella and its phylogenetic affinities within the molluscs are therefore regarded here as uncertain. Transitional forms between Anabarella and Watsonella have been reported by Gubanov et al. (1999), and Kouchinsky (1999) emphasised their existing similarities in ultrastructure. Therefore, Watsonella may be closely related to the helcionelloids ( $\mathrm{Li}$ et al., 2011). The mollusc assignment relies on the presence of growth lines, witnessing the incremental growth typical of that group and imprints of the shell ultrastructure on the internal molds, which correspond to a molluscan shell organisation ( $\mathrm{Li}$ et al., 2011). 
The genus Heraultia Cobbold, 1935, junior homonym of a dipteran insect (Villeneuve, 1920), was renamed Heraultipegma by Pojeta and Runnegar (1976). According to these authors, Heraultipegma differs from Watsonella in its aperture, especially its anterior and posterior areas. Indeed, Cobbold (1935) described a very wide posterior gape in Heraultipegma, whereas he considers it as narrow to absent in Watsonella. This observation was emphasised by Pojeta and Runnegar (1976), who clearly separated the two genera. However, Kerber (1988) noticed that the gapes are very similar in both genera. Landing (1988) described long gapes in the posterior part of the aperture of Watsonella, too. Therefore, Landing (1989) tentatively assigns the observed differences in wideness to different resistance properties to compression and synonymised Heraultipegma with Watsonella. He suggested that juvenile specimens of Watsonella may be more resistant to compaction than larger ones. This statement is not supported by the present material as small and large specimens are independently more or less affected by compaction. The closure of the aperture (so the shape and wideness of the gape) probably depends on the direction of compression so it is due to the orientation of the conch during sedimentation and burial. The gapes might not be used as a diagnostic character at generic nor specific rank and are highly similar in Heraultipegma and Watsonella. All authors agree now in considering the former as junior synonym of the later, a statement adopted herein (Landing, 1989; Parkhaev, 2001; Li et al., 2011).

Watsonella crosbyi Grabau, 1900

Figures 14.1-33 and 15.1-14

1888 Fordilla troyensis Barrande; Shaler and Foerste, p. 28, pl. 1, fig. 4.

1890 Fordilla troyensis; Walcott, p. 615, pl. 73, fig. 1.

1900 Watsonella crosbyi Grabau, 1900, p. 632, pl. 1, figs. 9a-g.

1935 Heraultia varensalensis Cobbold, 1935, p. 38-40, pl. 2, fig. 1a-10b.

1974 Heraultia sibirica Missarzhevsky, 1974, p. 188, pl. XXIV, figs. 1-3.

1975 Heraultia varensalensis; Müller, p. 168180, pl. 19, figs. 1-11.

1976 Heraultia varensalensis; Runnegar and Jell, p. 1-8, fig. 8.
1976 Heraultipegma varensalensis; Pojeta and Runnegar, p. 54, pl. 2, figs. 1-3.

1976 Watsonella crosbyi; Pojeta and Runnegar, p. 56 , pl. 3, figs. $1-4$.

1979 Heraultipegma varensalensis; Qian et al., p. 223, pl. IV, figs. 7-10.

1980 Heraultipegma sp.; Yin et al., p. 158, pl. 14 , figs. $6,7$.

1982 Heraultipegma varensalensis; Luo et al., p. 194-195, pl. 21, figs. 9-12, 15.

1982 Heraultipegma yunnanensis He and Yang, 1982, p. 90, pl. 1, figs. 1-3.

1983 Heraultipegma n. sp.; Bengtson and Fletcher, fig. 2d.

1983 Heraultipegma varensalensis; Runnegar, fig. 9.

1984 ?Fordilla troyensis; Brasier, p. 245, fig. 3d.

1984b Heraultipegma sp.; Yu, p. 33, pl. 2, fig. 13.

1984 Heraultipegma varensalensis; Xing et al., pl. 10 figs. 16, 17.

1985 Heraultipegma varensalensis; Runnegar and Pojeta, fig. 20 (upper).

1987b Heraultipegma yannanese; Yu, p. 214, pl. 60 , figs. 1-8.

1988 Heraultipegma varensalensis; Mambetov, p. 149, pl. XVIII, fig. 10.

1988 Watsonella crosbyi; Landing, p. 691, figs. 5.16, 5.17, 5.20.

1988 Watsonella varensalensis; Kerber, p. 159, pl. 4, figs. 1-13.

1989 Heraultipegma cf. varensalensis; Khomentovsky and Karlova, p. 53, pl. V, figs. 3a, b.

1989 Watsonella crosbyi; Landing, p. 566-573, figs. 3.1-3.4.

1989 Watsonella crosbyi; Landing et al., p. 765, figs. 8.5, 8.8.

1995 Heraultipegma sp.; Pospelov et al., p. 41, pl. 6, fig. 2.

1996 Watsonella crosbyi; Esakova and Zhegallo, p. 172, pl. XX, figs. 6-10.

2001 Watsonella crosbyi; Parkhaev, p. 188, pl. XLII figs. 15, 16.

2003 Watsonella yunnanensis; Feng and Sun, p. 22-25, fig. 3.

2005 Watsonella crosbyi; Ushatinskaya and Parkhaev, fig. 2. 


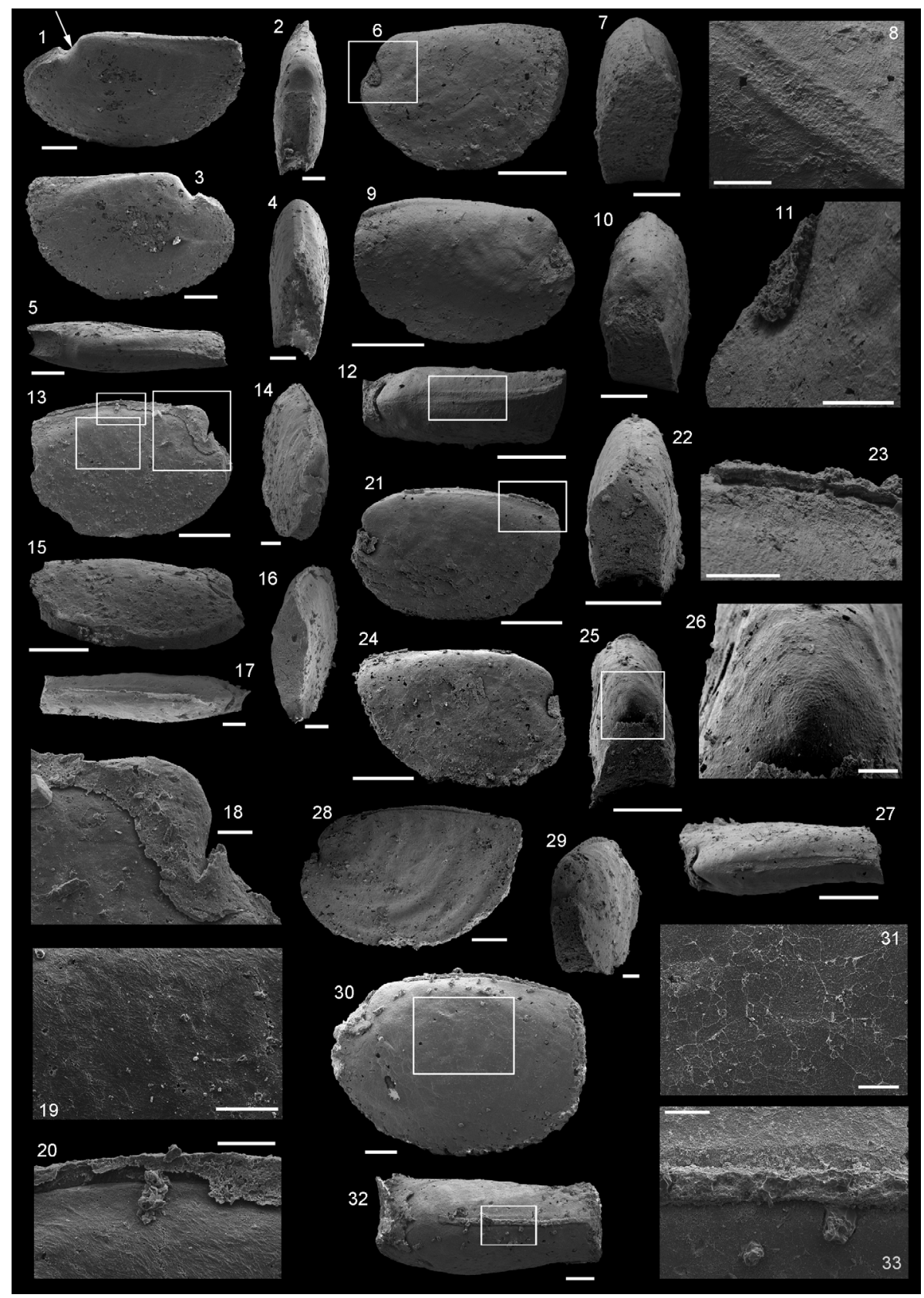

FIGURE 14. Watsonella crosbyi Grabau, 1900. 1-5. USTL1226/10: 1. Right lateral view, arrow shows concave subapical field; 2. Posterior view; 3. Left lateral view; 4. Anterior view; 5. Dorsal view. 6-12. USTL1241/7: 6. Right lateral view, square shows location of $11 ; 7$. Anterior view; 8 . Detail of polygonal imprints developed in the median dorsal furrow; 9. Left lateral view; 10. Posterior view; 11. Detail of concave subapical field with external mold; 12. Dorsal view, square shows location of 8. 13-20. USTL1236/4: 13. Left lateral view, lower right square shows location of 18, lower right, location of 19 and upper square, location of 20; 14. Posterior view; 15. Right lateral view; 16 . Anterior view, 17. Dorsal view; 18. Detail of apical area with external coating; 19. Detail of lateral fields with imprints of lamello-fibrillar shell structure; 20. Detail of dorsal furrow with thick external coating. 21-27. USTL1243/2: 21. Right lateral view, square shows location of 23; 22. Anterior view; 23. Detail of dorsal furrow filled with thick external coating; 24 . Left lateral view; 25. Posterior view, square shows location of 26; 26 . Detail of apex with polygonal imprints; 27 . Dorsal view. 28-29. USTL1209/8: 28. Right lateral view; 29. Posterior-lateral view; 30. 30-33. USTL1225/12: 30. Right lateral view, square shows location of $31 ; 31$. Detail of large but faint polygonal imprints on lateral fiels; 32 . Dorsal view, square shows location of 33; 33. Detail of dorsal furrow with external coating. Scale bars equal: 31, 33, 50 $\mu \mathrm{m} ; 8,11,18-20$, 23, 26, $29100 \mu \mathrm{m} ; 2$, 4, 14, 16, 17, 28, 30, 32, $200 \mu \mathrm{m} ; 1$, 3, 5, 7, 10, $300 \mu \mathrm{m} ; 13,15,6,9,12,21,22,24,25,27,500$ $\mu \mathrm{m}$. 


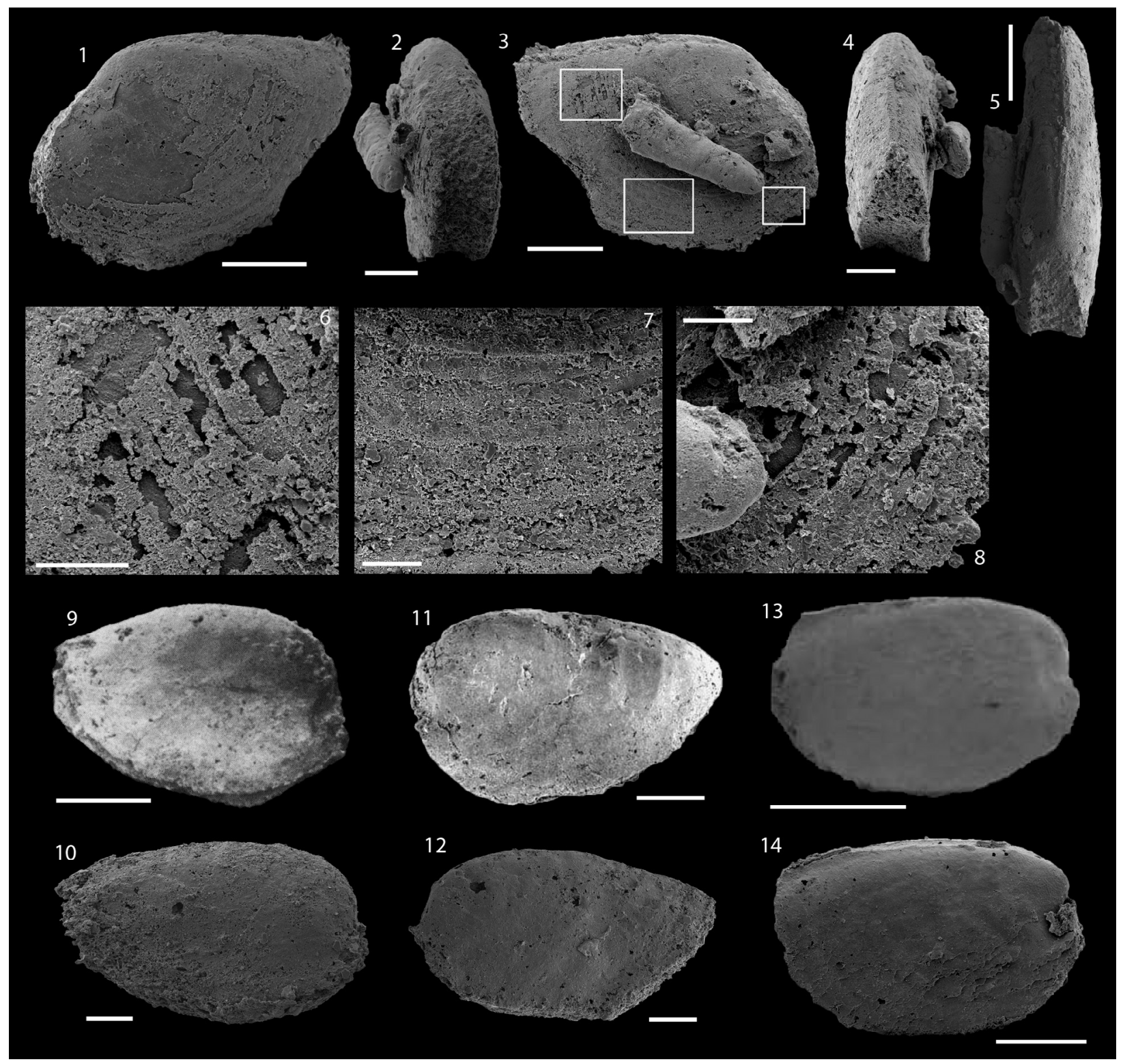

FIGURE 15. Watsonella crosbyi Grabau, 1900. 1-8. USTL1227/8: 1. Right lateral of specimen with phosphatised shell preserved; 2. Posterior view; 3. Left lateral view, upper square shows location of 6 , lower left square, location of 7 and lower right square shows location of 8: 4. Anterior view; 5. Dorsal view; 6 . Detail of shell with growth lines, internal mold visible; 7. Detail of shell with growth lines; 8 . Detail of shell with growth lines, internal mold visible. 9. Left lateral view of specimen PIN 4664/1525 of Watsonella crosbyi Grabau, 1900 in Gravestock et al. 2001. 10. Left lateral view of USTL L12_067. 11. Right lateral view of specimen NIGP Mo 131363 identified as Watsonella yunnanensis (He and Yang, 1982) in Feng and Sun, 2003. 12. Right lateral view of USTL1214/15. Left lateral view of specimen N $3593 / 743$ identified as Heraultipegma sibirica Missarzhevsky, 1974 in Missarzhevsky, 1989. 14. Left lateral view of USTL1243/2. Scale bars equal: 6-10, 12, $100 \mu \mathrm{m} ; 2,4,300 \mu \mathrm{m} ; 1,3,5,11,13,14,500 \mu \mathrm{m}$,

2011 Watsonella crosbyi; Li et al., p. 309-319, figs. $1-3$.

Material. Hundreds of specimens including USTL1209/8, USTL1214/15, USTL1225/12, USTL1226/10, USTL1227/8, USTL1236/4, USTL1241/7, and USTL1243/2 preserved as phosphatic internal molds on which fragments of external molds (Figure 14.6, 14.13, 14.18, 14.20, 14.23) or phosphatised endolithic-microborers (Figure 14.6) are occasionally preserved. Three specimens (Figure 15.1-8) exhibit remains of the replaced shell.

Distribution. Section $\mathrm{K} 2$, samples $\mathrm{K} 2 / 3 \mathrm{~b}, \mathrm{~K} 2 / 3 \mathrm{~m}$, $\mathrm{K} 2 / 4 \mathrm{~b}, \mathrm{~K} 2 /{ }_{6}, \mathrm{~K} 2 /{ }_{7 e}$, and $\mathrm{K} 2 /{ }_{9 a}$; section $\mathrm{K} 3$, samples $\mathrm{K} 3 \mathrm{~B} / 3, \mathrm{~K} 3 \mathrm{~B} / 4, \mathrm{~K} 3 \mathrm{~B} / 7, \mathrm{~K} 3 \mathrm{~T} / 2 \mathrm{c}, \mathrm{K} 3 \mathrm{~T} / 2 \mathrm{e}, \mathrm{K} 3 \mathrm{~T} / 3 \mathrm{a}$, and 
$\mathrm{K} 3 \mathrm{~T} / 4 \mathrm{a}$; section $\mathrm{K} 4$, samples $\mathrm{K} 4 / 4 \mathrm{a}, \mathrm{K} 4 / 4 \mathrm{~b}, \mathrm{~K} 4 / 8, \mathrm{~K} 4 /$ 9 , $\mathrm{K} 4 /_{11}, \mathrm{~K} 4 / 17$, and $\mathrm{K} 4 / 21$; section $\mathrm{K} 5$, samples $\mathrm{K} 5 \mathrm{~b} / 3, \mathrm{~K} 5 \mathrm{~b} / 8, \mathrm{~K} 5 /_{16}, \mathrm{~K} 5 /_{17}, \mathrm{~K} 5 /{ }_{19}, \mathrm{~K} 5 / 25$, and $\mathrm{K} 5 / 32$.

Emended diagnosis. Shell in the form of a laterally compressed hood. Apex incurved, but not overhanging the subapical field. Lateral surface gently arcuate, occassionally quite flat in the middle and slopping off gently toward either end. Margins of the dorsum strongly angulate in the initial portion and more uniformly rounded in the almostmature shell or the earlier formed part of an adult. In some specimens, a median carina appears on the centre of the flattened dorsum. The lines of growth are gently arcuate forward, marking a lateral rounded projection or lip on each lateral surface. They are deflected backward on the dorsum, and arch over the carina, producing a pronounced dorsal sinus. The finer lines of growth frequently alternate with coarser wrinkles (emended after Grabau, 1900).

Remarks. The terminology used herein to describe $W$. crosbyi is detailed in Figure 13 and follows its assignment to the molluscs.

Description. The bilaterally symmetrical mold of the pseudobivalved-shell is composed of two gently convex, almost parallel, lateral-fields (Figure $14.1,14.4,14.7,14.10,14.14,14.16,14.22,14.25)$ joining at the dorsum (Figure 14.5, 14.12, 14.17, 14.27). Posteriorly, the dorsum leads to the apex, followed by the subapical field (between apex and posterior apertural margin; arrowed in Figure 14.1). The mold, and most probably the thin envelopingshell, are elongate-oval in lateral view and strongly oval to subrectangular in transverse section (Figure $14.1,14.6,14.13,14.21,14.28,14.30)$. In dorsal view, the mold is suboval and elongate to rectangular, with a relatively constant width (Figure 14.12) or with a slight constriction of the anterior half of the dorsum (Figure 14.27).

Two variably developed dorsal folds emerge and diverge some distance from the apex and go up toward the anterior margin of internal molds. They are almost parallel in the median dorsal area and converge, occassionally join, in a carina at the anterior margin. They delimit a median furrow which generally achieves its maximum depth about the median area and rises up anteriorly (Figure $14.5,14.8,14.12,14.27)$. In some specimens, the internal mold of the furrow exhibits a granular structure (Figure 14.8). In lateral view, the dorsum is generally slightly convex (Figure 14.9, 14.13, $14.21,14.28)$, even if straight dorsa rarely occur (Figure 14.1, 14.3).
The subapical field is a very short and generally concave, sinus-like structure between the apex and the posterior apertural margin (Figure 14.1, 14.28). In a few cases, the apex overhangs the curved posterior apertural margin (Figure 14.21). Generally, the posterior portion of the aperture projects beyond the apex in a beak-like structure (Figure 14.1, 14.3). The development of a sinus under the apex depends upon how much the curvature of the posterior apertural margin is developed. A strongly curved posterior apertural-margin defines a well-developed sinus, whereas the sinus is faint and the posterior-field almost straight when the posterior margin is not curved. The curvature of the posterior apertural margin, which greatly controls the shape, is highly variable (Figure 14.1 to 14.28). A well-developed sinus delimits a protected area, in which the external molds are commonly preserved (Figure 14.9, 14.24, 14.27-28).

The aperture is elongate slit-like and generally shows a constant width from the posterior to the anterior apertural margin (Figure 14.2, 14.4, 14.7, $14.10,14.14,14.16,14.22,14.25)$. The width of the aperture randomly varies among specimens, independently from their size. The apertural margin is curved to half-circular in lateral view. The apical margin is rounded to rectangular, whereas the antero-dorsal margin is rounded to acute, underlining a variably developed dorsal carina (Figure $14.5,14.12,14.17,14.23,14.27,14.32$ ). Comarginal folds, originated in the apical region of lateral fields, are preserved on internal molds (Figure 14.6, 14.9, 14.28). The latter also imprint the microstructure of the shell on both lateral fields and rarely apex (Figure 14.19-20, 14.26, 14.31).

Two main types of structures preserved on internal molds inform on the polygonal (Figure $14.8,14.26,14.31)$ and lamello-fibrillar shell structures (Figure 14.19-20). The polygonal structures approximately measure $20 \mu \mathrm{m}$, are irregular in shape, and occupy a restricted surface of the internal molds, such as the apex and the dorsal margins (dorsalmost part of the lateral fields). They are smaller, more spaced, and pronounced on the apex surface (Figure 14.26) than on the upper part of the lateral fields (Figure 14.31). Central tubercles are absent (Figure 14.31). The fibers constituting the lamello-fibrillar ultrastructure are less than 1 $\mu \mathrm{m}$ in diameter and arranged in variable orientations (Figure 14.19-20) almost covering the entire surface of the lateral fields.

Remains of an external coating are exceptionally preserved on some internal molds (e.g., Figure 14.13-20). The thickness of the shell can be 
deduced from the space left between the internal and external mold. The shell seems to be thin on the lateral fields and thickens laterally to the dorsal folds and subapical field (Figure 14.12, 14.18, 14.20). The shell may have been particularly rough and thick in the subapical field (Figure 13). Remains of an external coating (Figure 14.13, $14.20-21,14.23--24,14.28,14.30-33)$ are common on the dorsal area, where the coating roughly fills the dorsal median furrow, revealing a thin, maybe thinning shell in this area (Figure 13).

Two specimens (one of which is figured in Figure 15.1-8) exhibit an almost complete phosphatic coat of the shell. Comarginal growth lines on external coating are more tightly spaced (about $30 \mu \mathrm{m}$ : Figure 15.6-8) than observable on internal molds.

Discussion. W. varensalensis (Cobbold, 1935) can be considered with confidence a junior synonym of $W$. crosbyi, as there is strictly no morphological variations between type assemblages which would justify such splitting, as already noticed by Landing et al. (1989), Esakova and Zhegallo (1996), and Li et al. (2011). He and Yang (1982) differentiated $W$. yunnanensis from $W$. crosbyi by their longer and narrower shell, and long extensions in the apex area. Finally, $W$. sibirica Missarzhevsky, 1974 was differentiated from all other species by its relatively long anterior field, a more curved anterior apertural margin, and its more convex lateral fields. However, as already stated by $\mathrm{Li}$ et al. (2011), the $W$. sibirica morphotype is included within W. yunnanensis (He and Yang, 1982) variability. Observations of new material from France agree with such a consideration: the assemblage studied herein shows a high morphological variability (including length/height ratio) which definitely encompasses the $W$. yunnanensis (Figure 14.1112), W. sibirica (Figure 14.13-14) and W. crosbyi (Figure 14.9-10) morphotypes. Therefore, W. yunnanensis and $W$. sibirica are considered as junior synonyms of $W$. crosbyi. Along with morphological variability, taphonomical variability (internal mold, coating or phosphatisation of the shell) might have influenced the erection of various genera and species.

Specimens illustrated by Steiner et al. (2007, figs. 6A, D), and observations made herein on internal molds associated with external coating, suggest the shell thickens in different areas including the posterior lateral-fields; consequently, the internal molds of the latters are less convex than the external surface of the original shell.

The information on the ultrastructure of the shells provided by the internal molds presented herein are the same than those described for $W$. crosbyi by Kouchinsky (1999, except from the stepwise ultrastructure), Feng and Sun (2003) and in Li et al. (2011). The polygonal imprints found on the internal molds of $W$. crosbyi have been interpreted in two different ways. According to Ushatinskaya and Parkahev (2005), the smaller but more pronounced polygons are interpreted as imprints of a pallial myostracum (muscle attachment), whereas larger and faint polygons reproduce cells of the outer epithelium. Kouchinsky (1999) and Vendrasco et al. (2010) interpret all polygonal structures as replica of the prismatic shell layer: the polygons correspond to molds of prismatic shell microstructure prior to significant degradation of the organic (conchiolin) interprism walls. On most of the lower Cambrian internal molds of molluscs, the prismatic imprints are not preserved on the entire surface. In particular, the polygonal structures found on internal molds of $W$. crosbyi are restricted to the dorsum and the apical area, whereas the remaining surface is covered by imprints of a lamello-fibrillar shell microstructure. If the large polygons consisted of reproductions of outer epithelium cells, they should be preserved in patches on the internal mold that might vary from specimen to specimen. Moreover, the observation of Vendrasco et al. (2010) that "polygonal textures are often on the same horizontal plane as imprints of other types of shell microstructure and endoliths, indicating that phosphate precipitated directly on the surface of the inner shell" is confirmed by the identification, on specimens from the Montagne Noire, of another type of microstructural imprints (lamello-fibrillar) in the same plane as the polygonal texture. Vendrasco et al. (2010) further point out that the polygons are often distinct, with high relief. In the present case, the relief is particularly high in the apical area of $W$. crosbyi. A cast or imprint of mantle epithelium should not produce polygons with raised edges. Finally, the size of the polygons of $W$. crosbyi (about $20 \mu \mathrm{m}$ ) fits the range of the organic framework of the prismatic shell layer rather than smaller mantle epithelial cells.

Other occurrences. Tommotian of China: Maidiping Formation (Watsonella crosbyi Zone), Maidiping and Gaoqiao, Emei County, (Xing et al., 1984; Yu, 1987b) and Hongzhai and Bangou, Ganlu County (Yu, 1987b), Sichuan Province; Upper Maidiping Formation (Watsonella crosbyi Zone), Yangjiadun, Eastern part of the Yangtze Gorge, Yichang County, Hubei Province (Qian et al., 1979); Dahai Member, Zhujiaqing Formation (Watsonella crosbyi Zone), Dahai, Zhujiaqing and Jia- 
shewan, Huize County (Luo et al., 1982, 1984; Yu, 1987b; Qian, 1989; Qian et al., 1996; Li et al., 2011), Xiaotan, Yongshan County (Qian, 1989; Li and Xiao, 2004; Li et al., 2011), Xianfeng and Baizai, Xundian County (Yu, 1987b), Yulu, Huize County (Feng and Sun, 2003), Yunnan Province; Huangshandong Member, Tongying Formation (Watsonella crosbyi Zone), Huangshandong (Yu, 1987b; Qian, 1989; Li et al., 2011) and Tianzhushan (Yu, 1987b), Yichang County, Hubei Province; Meishucun Formation (Watsonella crosbyi Zone), Meishucun, Jinning County, Yunnan province (He and Yang, 1982).

Tommotian to Atdabanian of Avalonia: Red limestone boulders, Weymouth Formation, Tommotian (Watsonella crosbyi Zone), Sandy Cove and Pleasant Beach, Cohasset, Massachusetts, USA (Shaler and Foerste, 1888; Grabau, 1900; Pojeta and Runnegar, 1976; Landing, 1989); Lower Member, Weymouth Formation, Tommotian (Watsonella crosbyi Zone), Hoppin Reservoir, North Attleboro area, Massachusetts, USA (Landing, 1988); Chapel Island Formation to Cluslett Formation, Tommotian to early Atdabanian (Watsonella crosbyi Zone to Camenella baltica Zone), Little Dantzic Cove, Southeastern Newfoundland (Landing, 1989).

Tommotian of Mongolia: Bayan-Gol Formation (Watsonella crosbyi Zone), Zhavkhan Province (Voronin et al., 1982; Esakova and Zhegallo, 1996).

Tommotian of Siberia: Tommotian Stage (no Formation or Biozone specified), lower reaches of Lena River, northern flanks of the Anabar Uplift (Ushatinskaya and Parkhaev, 2005); Member IIlb, Kessyusia Formation (Nochoroicyathus sunnagicus Zone), Olenek Uplift sections (Khomenthovsky and Karlova, 1993; Kouchinsky, 1999); Pestrotsvet Formation, Nochoroicyathus sunnagicus Zone, Selinde and Malyi Chaydakh rivers, (Khomentovsky and Karlova, 1993), Nemnekey section between the Gonam and Nemnekey rivers (Khomentovsky and Karlova, 1993) and Dokidocyathus regularis Zones, Selinde River, (Rozanov et al., 1969; Matthews and Missarzhevsky, 1975; Khomentovsky and Karlova, 1993; Kruse et al., 1995), Lena River, (Rozanov et al., 1969; Matthews and Missarzhevsky, 1975; Kruse et al., 1995) and Aldan River (Rozanov et al., 1969); Krasnoporog Formation (Ladatheca annae Zone), Sukharikha River (Rowland et al., 1998); Unit 4, Medvezh'ya Formation (Nochoroicyathus sunnaginicus Zone), Kotui River (Rozanov et al., 1969; Missarzhevsky, 1989; Kouchinsky, 1999); Upper Kessyusa Forma- tion (Watsonella-Lapwothella Zone), Olenek and Khorbusuonka rivers (Knoll et al., 1995).

Tommotian to Botoman of Australia: A to C Members, Sellick Hill Formation, Botoman (Bemella communis-Stenotheca drepanoida mollusc zones or Halkieria parva SSF zone), Myoponga Beach Fleurieu Peninsula (Parkhaev, 2001); Mount Terrible Formation, Tommotian (No Biozone specified), Fleurieu Peninsula, Australia (Daily, 1976).

Genus XIANFENGELLA He and Yang, 1982

1980 ?Scutatestomaconus Chen and Zhang, 1980, p. 192.

1982 Xianfengella $\mathrm{He}$ and Yang, 1982, p. 90 (partim quoad $X$. prima).

1986 Heraultipegma Pojeta and Runnegar; Jermak and Pelman, p. 194 (partim quoad H. charaulachica).

2001 Xianfengella; Gravestock et al. 2001, p. 179.

2010 Xianfengella; Parkhaev and Demidenko, p. 1058, 1059.

Type species. Xianfengella prima He and Yang, 1982, Tommotian (Watsonella crosbyi Zone), Meishucun, Jinning County, Yunnan Province, China.

Emended diagnosis. Conch cap-shaped, low conical. Apex curved (almost half whorl), hooked downwards and hoverhanging the posterior margin. Anterior field strongly convex in lateral view. Restricted posterior field concave and sharply folded. Comarginal, subapical notch on internal mold (comarginal thickening of the shell to comarginal partition of the shell chamber). Aperture varies from elongate (elliptical to subelliptical) to circular, convex to sigmoid in lateral view, posterior apertural margin cut by low and wide, concave sinus. Exterior of internal molds smooth (emended after Parkhaev and Demidenko, 2010).

Remarks. The genus Xianfengella $\mathrm{He}$ and Yang, 1982 is not considered herein as a Rugaeconidae (superfamilly Yochelcionelloidea; Runnegar and Jell, 1976) as suggested by Parkhaev and Demidenko (2010), because the structure of the subapical concavity of internal molds is not considered a parietal train (posterior extension of the shell) but the subapical termination of the cavity separated from the main part of the cavity by a projection of the shell (this structure corresponds to a subapical, comarginal notch in the internal molds). This partition wall is similar to the "pegma-like" structure (sensu Runnegar and Pojeta, 1974) described in many helcionelloids. However, as noticed by Peel (1991), the homology between 
such a shell projection and the rostroconch pegma is very putative and debatable. The typical rostroconch pegma is indeed a transverse strenghtening bar, not a septum. In conclusion, Xianfengella is treated herein as unassigned at supra-generic level within the Mollusca.

Xianfengella prima $\mathrm{He}$ and Yang, 1982 Figure 16.1-6

1980 ?Scutatestomaconus latus Chen and Zhang, 1980, p. 192, pl. 1, figs. 47-49.

1982 Xianfengella prima He and Yang, 1982, p. 91, pl. 2, figs. 4, 6, pl. 3, figs. 21-23.

1988 Latouchella? courtessolei Kerber, 1988, p. 172, pl. 7, figs. 1-6.

1994 Igorella xundianensis Wang, 1994, p. 11, pl. 3, figs. 4, 5.

2000 Igorella minuta Feng, Sun and Qian in Feng et al., 2000, p. 366, pl.3, figs. 1-8.

2005 Xianfengella prima; Yu, pl. 1, fig. 9.

2006 Xianfengella prima; Demidenko and Parkhaev, text-figs. $5 z, 5 i$.

Material. 17 phosphatic internal molds including USTL1211/14 and USTL1246/1.

Distribution. Section $\mathrm{K} 2$, samples $\mathrm{K} 2 / 3 \mathrm{~b}, \mathrm{~K} 2 / 3 \mathrm{~m}$, and $\mathrm{K} 2 /{ }_{12 \mathrm{~m}}$; section $\mathrm{K} 3$, samples $\mathrm{K} 3 \mathrm{~T} / 2 \mathrm{e}$ and $\mathrm{K} 3 \mathrm{~T} /$ 3a; Section K4, samples $\mathrm{K} 4 / 2, \mathrm{~K} 4 / 4 \mathrm{a}$, and $\mathrm{K} 4 / 9$; Section $\mathrm{K} 5$, samples $\mathrm{K} 5 \mathrm{~b} / 4, \mathrm{~K} 5 /{ }_{12}, \mathrm{~K} 5 /_{17}, \mathrm{~K} 5 /{ }_{19}, \mathrm{~K} 5 /_{32}$, and $\mathrm{K} 5 / 41$.

Description. The internal mold of the conch is capshaped, almost bilaterally symmetrical (Figure 16.1, 16.6), low conical (mean height/length ratio of $2 / 5$ with a maximum length of $3300 \mu \mathrm{m}$, and has a height of $1480 \mu \mathrm{m}$ ) and laterally compressed (mean width/length ratio of $1 / 2$ with a maximum width of $1450 \mu \mathrm{m}$ ). The apex is blunt, rounded, shifted toward the posterior (arbitrary defined) side of the conch, curved downward and overhangs the posterior margin (Figure 16.1-6). In lateral view, the anterior field (from the apex to the anterior margin) is convex (Figure 16.2, 16.5). The posterior field (from the apex to the posterior margin) is restricted and deeply concave (Figure 16.2, 16.5). A subapical, comarginal notch in the internal molds, corresponding to a shell thickening/projection or fold, partitions the internal cavity into a subapical chamber and main chamber (arrowed in Figure 16.2). The subapical, chamber is rounded triangular in apertural view. The lateral fields are straight to slightly convex (Figure 16.3-4). The aperture is elliptically elongate (Figure 16.1, 16.6). The margin is convex to sinusoidal. The external surface of the internal mold bears fine and faint transverse growth lines (Figure 16.6).

Comparison. According to Parkhaev (in Gravestock et al., 2001), Xianfengella prima $\mathrm{He}$ and Yang, 1982 differs from Xianfengella yatesi Parkhaev in Gravestock et al., 2001 in its narrower shape and its more rounded apex. The systematic importance of such characters is questionnable as they can be taphonomically or ontogenetically controlled. However, a bibliographic revision does not allow assessing the probable junior synonymy of $X$. yatesi, and re-interpretation of type material would be necessary.

Other occurrences. China: Zhongyicun Member, Zhujianqing Formation, Nemakit-Daldynian (Anabarites trisulcatus-Protoherzina anabarica Zone), Xianfeng, Xundian County, Yunnan Province (Parkhaev and Demidenko, 2010); Huangshandong Member, Dengying Formation, Nemakit-Daldynian (Paragloborilus subglobosus-Purella squamulosa Zone), Meishucun, Yichang County, Hubei Province (He and Yang, 1982).

$$
\text { Genus MERISMOCONCHA Yu, } 1979
$$

1979 Merismoconcha Yu, 1979, p. 257.

1984a Merismoconcha; Yu, p. 440.

1984a Minymerisma Yu, 1984a, p. 439.

1984a Yangtzemerisma Yu, 1984a, p. 437-438.

1987b Merismoconcha; Yu, p. 137-138.

1987b Minymerisma; Yu, p. 135-136.

1987b Yangtzemerisma; Yu, p. 132-133.

1988 Merismoconcha; Kerber, p. 168.

2008 Merismoconcha; Yu, p. 189.

2008 Minymerisma; Yu, p. 183.

2008 Yangtzemerisma; Yu, p. 185.

Type species. Merismoconcha multisegmentata Yu, 1979, Nemakit-Daldynian to Tommotian (Paragloborilus subglobosus-Purella squamulosa Zone to Watsonella crosbyi Zone), Gaoqiao, Emei County, Sichuan Province, China.

Emended diagnosis. Minute, narrowly elongate, spoon-shaped conchs. Dorsal side of internal mold divided into two unequal parts (body segment longest) by a transverse notch corresponding to a transverse costae in the shell. Surface ornamented with concentric rugae, radial ridges or lines and growth lines. Aperture elongate-oval (emended after Yu, 2008).

Discussion. The muscle scars described by $\mathrm{Yu}$ (1984, 1987b, 2008) in Merismoconcha Yu, 1979 and synonyms (Minymerisma Yu, 1984 and Yang- 


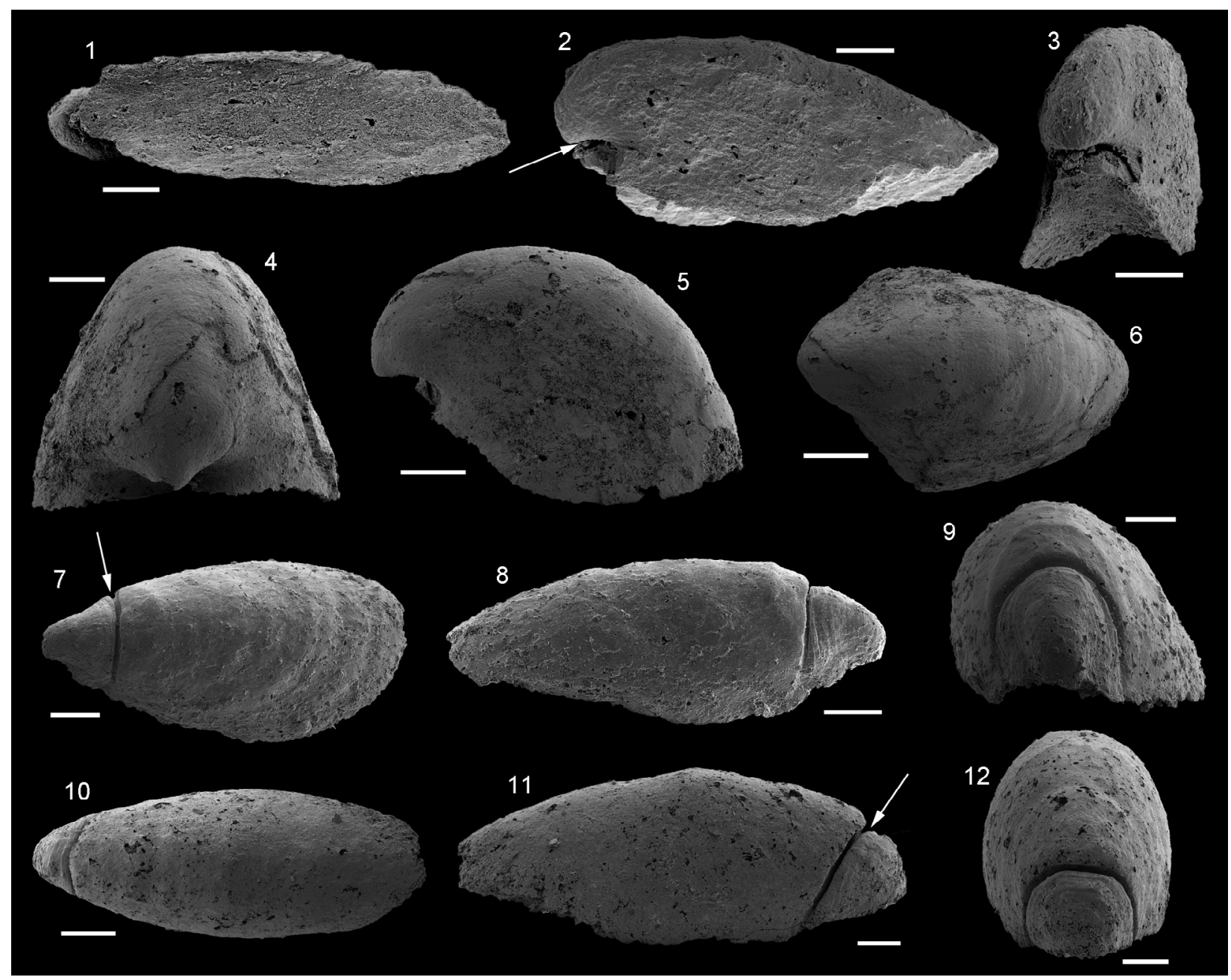

FIGURE 16. 1-6 Xianfengella prima He and Yang, 1982. 1-3. USTL1246/1: 1. Apertural view; 2. Lateral view, arrow shows subapical, comarginal notch in the internal molds; 3. Apical view. 4-6. USTL1211/14: 4. Apical view; 5. Lateral view; 6. Upper view. 7-12 Merismoconcha sp. 7-9. USTL1234/1: 7. Upper view, arrow shows the internal mold transverse-furrow; 8. Lateral view; 9. Apical view. 10-12. USTL1215/16: 10. Upper view; 11. Lateral view, arrow shows the internal mold transverse-furrow; 12. Apical view. Scale bars equal: 1, 4, 9, 11, 12, $200 \mu \mathrm{m} ; 5-8,10,300 \mu \mathrm{m}$.

tzemerisma Yu, 1984) are not visible on the studied specimens, as already noticed by Kerber (1988). The preservation of the specimens used by the author (Yu, 1984a; 1987b and 2008) to conclude on their muscle organisation is poor (e.g., holotype of Yangtzemerisma in Yu (1984a), figure 2), therefore, the structures interpreted by Yu (1984a, 1987b, 2008) as muscle scars may represent preservational artefacts. Moreover, the organisation of the internal mold into three segments, as suggested by Yu (1984a, 1987b, 2008), is doubtful: in Yangtzemerisma Yu, 1984, the rostrate segment is only observed on the holotype of the type species, Yangtzemerisma rarum Yu, 1984, and most probably corresponds to phosphate crusts unrelated to the original conch. In specimens of Merismocon- cha presented by Yu (1979, 1984a, 1987b, 2008), the second segment may result from breakage of the internal mold as this structure is also only present on the holotype of the type species Merismoconcha multisegmentata Yu, 1979. Minymerisma is herein considered as a morphological variation of Merismoconcha. Yu (2008) distinguishes Minymerisma from Merismoconcha based on the lack of the muscle scars typical of Merismoconcha. Nevertheless, these supposed muscle scars may correspond to preservational artefacts.

\section{Merismoconcha sp. \\ Figure 16.7-12}

Material. About 20 phosphatic internal molds including USTL1215/16 and USTL1234/1. 
Distribution. Section 2, sample $\mathrm{K} 2 / 6$; section 3, samples $\mathrm{K} 3 \mathrm{~T} / 2 \mathrm{c}, \mathrm{K} 3 \mathrm{~T} / 2 \mathrm{e}$; section 5 , sample $\mathrm{K} 5 / 12$, $\mathrm{K} 5 / 19$, and $\mathrm{K} 5 / 32$.

Description. The internal mold of the conch is capshaped, almost bilaterally symmetrical (Figure 16.7, 16.9-10, 16.12), low conical (mean height/ length ratio of $1 / 2$ with a maximum length of 3000 $\mu \mathrm{m}$ and height of $1380 \mu \mathrm{m}$ ) and laterally compressed (mean width/length ratio of 3/7 with a maximum width of $1220 \mu \mathrm{m}$ ). The apex is blunt, rounded, shifted toward one side of the conch, and projects over the subapical margin (Figure 16.8-9, 16.11-12). The dorsal field is slightly convex (Figure 16.8, 16.11), while the subapical field is slightly concave (Figure 16.8, 16.11). The apertural margin shows approximately the same convexity than the dorsal fields, so the conch is elliptical in lateral view, with apex lying at one extremity. The internal cavity is splitted into two. The smallest apical cavity represents $1 / 3$ to $1 / 5$ of the conch length. It is separated from the large body cavity by a sinuous, deep and distinct transverse furrow on the internal molds (arrowed in Figure 16.7, 16.11), which corresponds to an extension of the shell partitioning the cavity. The lateral fields are considerably convex in apical or anterior view: the cross section of the conch is oval (Figure 16.9, 16.12). The aperture is elliptically elongate (Figure 16.7, 16.10). The internal mold of the apex bears fine striations (Figure 16.12). The internal mold of the main body cavity exhibits equally spaced, slightly prominent, comarginal ribs (Figure 16.7-8).

Discussion. The genus Merismoconcha is considered herein to belong to the Mollusca because it exhibits striations corresponding to growth lines, typical of molluscs. However, the class, order and family are not identified because of the peculiar organisation of the shell into two (probably not three) cavities (as suggested by Yu, 1984a, 1987b, 2008), which is unknown in other molluscan groups although it may correspond to an embryonic shell. Yu (1983) created a special class for the genus Merismoconcha, the Merismoconchia Yu, 1983 based on their assumed metameric organisation. However, the present material enables to determine that Merismoconcha is not segmented into three parts, but that the apical chamber may be compared with a protoconch. Therefore, the class Merismoconchia which diagnosis was mainly based on shell partition into three parts may not be valid.

Class, Order, Family and genus uncertain Morphotype A Figure 17.1-9
Material. Two phosphatic internal molds on which fragments of external molds (Figure 17.6-7) are occasionally preserved including specimens USTL1247/1 and USTL1258/8.

Distribution. Section K2, sample K2/ $12 \mathrm{~m}$; section $\mathrm{K} 5$, sample $\mathrm{K} 5 / 12$.

Description. The internal mold of the conch is cone-shaped, up to $1115 \mu \mathrm{m}$ long, $630 \mu \mathrm{m}$ wide and $560 \mu \mathrm{m}$ high (height/length ratio about 1/2). The aperture is circular (Figure 17.1) to triangular (Figure 17.8) in outline in upper view, flat in lateral view. The submarginal rounded apex lies more or less in the plane of bilateral symmetry (Figure $17.1-2,17.8$ ). The dorsal field (the largest surface between the apex and the apertural margin) is slightly convex in lateral view (Figure 17.3-4, 17.9). The subapical field (the surface under the apex) is straight and almost vertical (Figure 17.3$4,17.9$ ). The subapical apertural margin is more or less retracted toward the internal part of the conch in a faint sinus (Figure 17.4, 17.6). The lateral fields are straight in anterior/posterior view (Figure 17.2). The external mold consists of a thin and flat layer of phosphate (Figure 17.1, 17.3-5). The surface of the internal mold exhibits comarginal ribs of ca. $10 \mu \mathrm{m}$ in thickness (Figure 17.2, 17.4-5, 17.79). Small but marked polygonal imprints (about 5 $\mu \mathrm{m}$ in width) are present on the internal mold, particularly on the surface between the comarginal ribs (Figure 17.7). Molds of microbial borings are visible between comarginal ribs testifying of the former presence of shell material (Figure 17.7).

Discussion. Presence of both internal and external molds allows interpolations of shell characters. In accordance with the space between the internal and external molds (Figure 17.7), the shell might be relatively thick between the comarginal ribs and thin exactly at the top of the ribs (Figure 17.7). This observation, along with the flat and smooth external coating, corresponds to an inner shell thickening, and may correspond to a growth through lamellar addition, each rib corresponding to the external border of a lamella.

Comparison. The present specimens are tentatively considered representative of the phylum Mollusca because they exhibit polygonal structures corresponding to imprints of the prismatic shell layer typical of molluscs but further arguments are needed to confirm the assignment. The morphotype $\mathrm{A}$ is more or less similar to Asperoconus $\mathrm{Yu}$, 1979, which is cone-shaped and exhibits granulate structures on its internal mold. However, the internal mold is ornamented with pustules in Asperoconus (ribs in morphotype A) and the subapical field 


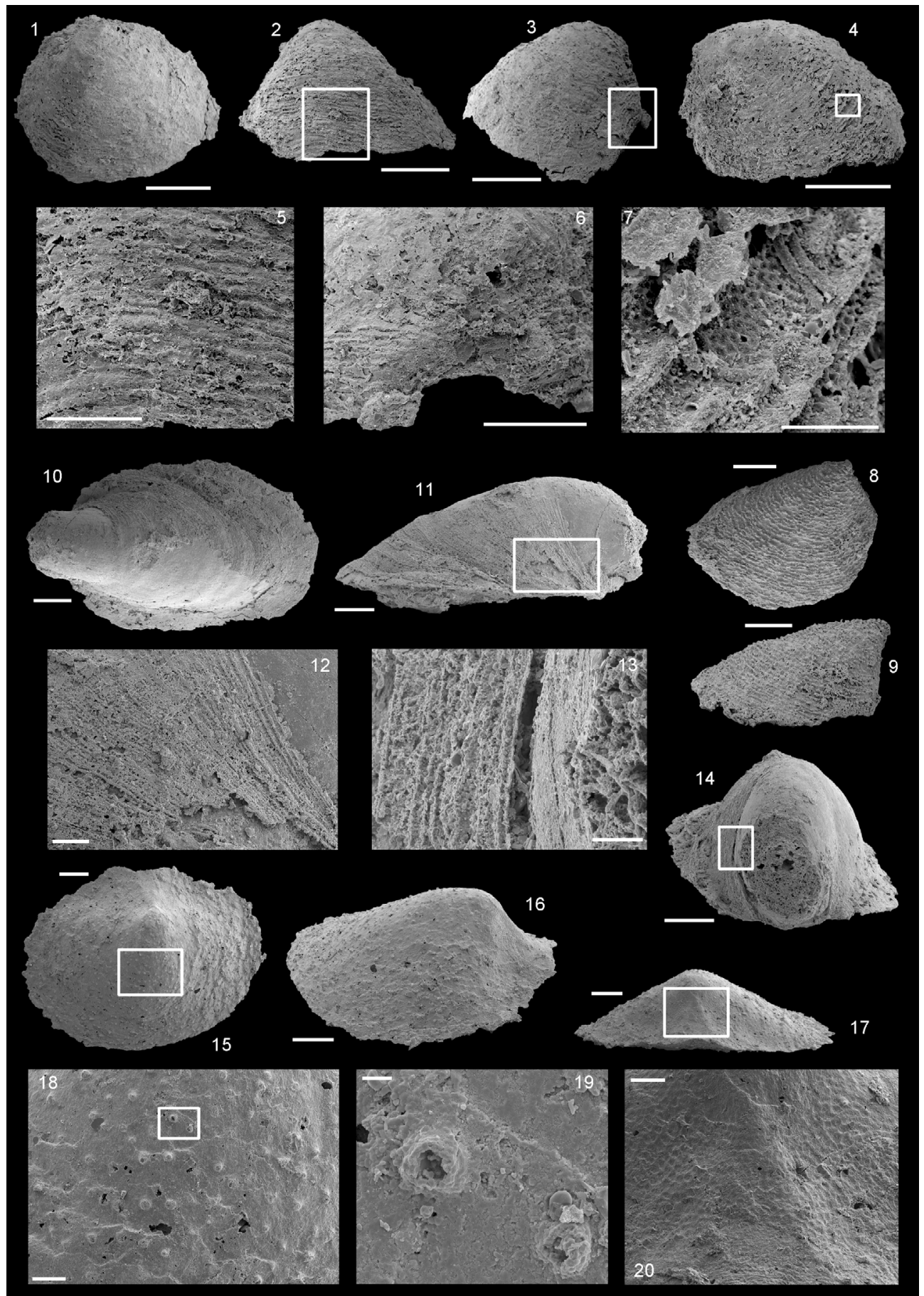

FIGURE 17. 1-9 Morphotype A. 1-7 USTL1258/8: 1. Upper view; 2. Abapical view, square shows location of 5; 3. Lateral-apical view, square shows location of $6 ; 4$. Lateral view, square shows location of $7 ; 5$. Detail of comarginal ribs of internal mold with flat external coating; 6 . Detail of subapical sinus; 7 . Detail of prismatic imprints between comarginal ribs of internal mold. 8-9. USTL1247/1: 8. Upper view; 9. Lateral view. 10-14 Morphotype B, specimen USTL1214/11: 10. Upper view; 11. Lateral view, square shows location of 12; 12. Detail of striated external coating; 13. Detail of distance between external coating and internal mold (shell thickness); 14. apical view, square shows location of 13. 15-20. Morphotype C, specimen USTL1215/10: 15. Upper view, square shows location of 18; 16 . Lateral view; 17. Apical view, square shows location of 20; 18. Detail of the surface of the internal mold with circular granules, square shows location of 19; 19. Detail of pierced circular granules; 20 . Detail of polygonal imprints on the subapical field. Scale bars equal: 19, $5 \mu \mathrm{m} ; 13,20 \mu \mathrm{m} ; 7,12,18,20,50 \mu \mathrm{m} ; 5,10,11,14-17,200 \mu \mathrm{m} ; 6,8,9,300 \mu \mathrm{m}$ $1-4,500 \mu \mathrm{m}$. 
is concave (straight in the present specimens). Asperconella Landing, 1996 shares with morphotype $A$ the presence of nodose comarginal ridges but it is cyrtoconic (curved). No further assignment is possible as no similar shell organisation has been described in the literature. On the other hand, the number of available specimens precludes the erection of new taxa.

\section{Morphotype B \\ Figure 17.10-14}

Material. One somewhat broken phosphatic internal mold with fragments of external mold USTL1214/11.

Distribution. Section K2, sample K2/6.

Description. The internal mold of this conch is slightly laterally compressed, with apex slightly curved downwards (Figure 17.11). The height is up to $725 \mu \mathrm{m}$ (Figure 17.11), the length $1650 \mu \mathrm{m}$ (Figure 17.10), and the width $900 \mu \mathrm{m}$ (Figure 17.10). The apex is rounded and overhangs the subapical apertural margin (Figure 17.11). The dorsal field is evenly convex in its apical portion but flattens toward the aperture (Figure 17.11). The subapical field is short and concave (Figure 17.11). The aperture is oval in upper view (Figure 17.10) and plane in lateral view. The lateral fields are straight (Figure 17.14). The aperture is oval and bordered by a delicate flange (Figure 17.10, 17.12, 17.14). The internal mold is smooth. The external coating consists of an assemblage of fine (ca. $5 \mu \mathrm{m}$ ) comarginal striae (Figure 17.12-13). The distance between the internal mold and the external coating is very thin (ca. $5 \mu \mathrm{m}$ ) but becomes wider (up to $15 \mu \mathrm{m}$ ) in some areas (Figure 17.13).

Discussion. Morphotype B is very similar in general outline to Igorella species. However, it clearly differs from lgorella in the shell ornamentation (ribs) which is expressed on inner and outer sides of the shell in Igorella (ribs are folds of the shell) but only on the external surface in the herein described specimens (ribs are shell thickening, the internal mold being smooth). Moreover, the conch of this morphotype is less laterally-compressed than Igorella conchs. This type of organisation is found in Oelandiella nazarovi (Zhegallo in Esakova and Zhegallo, 1996). In this sense, the present species is quite similar to $O$. nazarovi but it differs by the finer ornamentation, the less laterally compressed and less tightly coiled conch.

\section{Morphotype C \\ Figure 17.15-20}

Material. Two phosphatic internal molds including USTL1215/10.
Distribution. Section $\mathrm{K} 2$, sample $\mathrm{K} 2 /{ }_{6}$ and section $\mathrm{K} 3$, sample $\mathrm{K} 3 \mathrm{~T} / 2 \mathrm{c}$.

Description. The internal mold of the conch is low cap-shaped, up to $1300 \mu \mathrm{m}$ long, $1730 \mu \mathrm{m}$ wide, and $530 \mu \mathrm{m}$ high (length/width ratio about 3/4; height/length ratio about $2 / 5$ ) very rapidly expanding from the apex toward the aperture (Figure 17.15-17). The aperture is oval in outline (Figure 17.15) in upper view, flat in posterior view (apical side). The apex is shifted toward one side of the conch and placed at a distance of about $3 / 4$ of its length (Figure 17.17), so that the surface under the apex (subapical field) is smaller than the surface above it (dorsal field). In lateral view, the dorsal field is straight to slightly convex whereas the subapical field is slightly concave (Figure 17.16). The median part of the subapical field exhibits a triangular buttress framed on each side by two large but shallow depressions (Figure 17.17, 17.20). The subapical margin gently follows the triangular buttress and forms a faint triangular sinus in the median part of the subapical margin (Figure 17.17). Polygonal structures of $10 \mu \mathrm{m}$ wide are visible in the subapical area (Figure 17.20) and may correspond to replica of a prismatic shell layer. The external dorsal and lateral surfaces of the internal mold display randomly placed circular granules (Figure 17.15-16, 17.18-19). Those granules are either imperforate or pierced (Figure 17.19).

Discussion. The granules present on the external surface of the internal mold most probably correspond to pores in the original shell. Pierced granules (canals?) are intepreted as coated pores, whereas imperforate granules might represent completely filled pores. Except from the polygonal imprints of the prismatic layer, no information is available on the shell itself, which was most probably in carbonate composition and dissolved by etching.

Comparison. According to the general shape of the conch, the species is somewhat similar to Papilloconus explanatus Feng et al., 2000. However, circular granules are not reported on external molds of this species, only the primastic scars are known. In the Family Helcionellidae Wenz, 1938, some species with different outlines display a similar type of granules as Obscurania auriculata (Vassiljeva, 1990), but they clearly differ from the specimens described herein in the general shape of the conch.

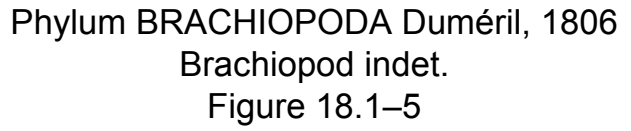




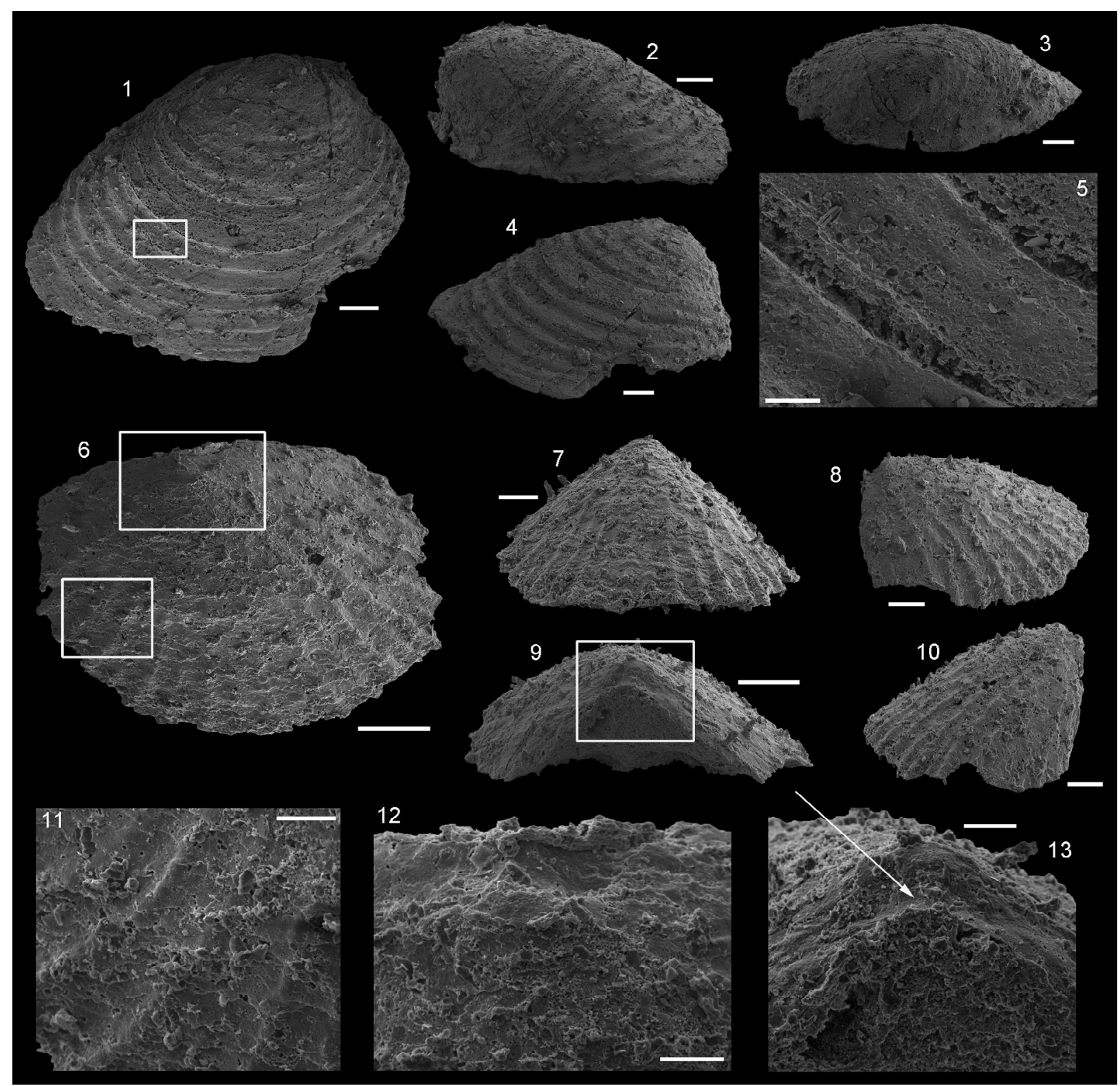

FIGURE 18. 1-5. Brachiopod indet. specimen USTL1223/2: 1. Upper view of dorsal valve, square shows location of 5; 2, 4. Lateral views; 3. Posterior view; 5. Detail of comarginal step-like structures corresponding to shell lamellae. 613. Khasagtina? specimen USTL1234/10: 6. Upper view, lower square shows location of 11, upper square shows location of 12; 7. Anterior view; 8, 10. Lateral views; 9. Posterior view, square show location of 13; 11. Detail of radial ribs; 12. Detail of groove parallel to the subapical apertural margin; 13. Detail of subapical area with sinus, arrow shows groove parallel to the subapical apertural margin. Scale bars equal: 5, $20 \mu \mathrm{m} ; 1-4,11-13,100 \mu \mathrm{m} ; 8,10,200$ $\mu \mathrm{m}, 6-9,300 \mu \mathrm{m}$.

Material. One phosphatic internal mold USTL1223/2.

Distribution. Section $\mathrm{K} 2$, sample $\mathrm{K} 2 / 16$.

Description. The internal mold is cap-shaped, up to $820 \mu \mathrm{m}$ long, $1020 \mu \mathrm{m}$ wide, and $400 \mu \mathrm{m}$ high (height/length ratio of $1 / 2$ ). The aperture is triangular in outline with a pronounced lateral elongation (Figure 18.1). The apex lies in the plane of symme- try (Figure 18.1). It is shifted toward the (conventional) posterior side of the conch (Figure 18.1). The surface between the apex and the anterior apertural margin is slightly convex to almost straight in lateral view (Figure 18.2, 18.4). The lateral fields are convex in posterior view (Figure 18.3). The subapical field is short and straight (Figure 18.2, 18.4). The surface of the internal molds is 
stepped and display comarginal lamellae originating at the apex (Figure 18.1, 18.4-5). The ribs are separated from each other by an average distance of $60 \mu \mathrm{m}$ (Figure 18.5).

Discussion. The present internal mold exhibits stepped comarginal lamellae originating at the apex that may correspond to a growth through lamellar addition, each rib corresponding to the external border of a lamella. Therefore, it is considered a brachiopod because shell lamellae are added to the posterior, lateral and anterior margins by peripheral growth creating step-like structures. Those step-like structures may affect the inner surface (e.g., Cyrbasiotreta, Eosiphonotreta) of the shell and could result in step-like structures on the outer surface of internal molds as seen in the present specimen. However, despite this brachiopodtype peripheral growth, the present specimen does not exhibit further brachiopod-like characters, such as muscle imprints or valve articulation structures.

Subphylum RHYNCHONELLIFORMEA Williams et al., 1996

Class KUTORGINATA Williams et al., 1996 Order KUTORGINIDA Kuhn, 1949

Superfamily NISUSIOIDEA Walcott and Schuchert, 1908

Family NISUSIIDAE Walcott and Schuchert, 1908

Genus KHASAGTINA Ushatinskaya, 1987

1987 Khasagtina Ushatinskaya, 1987, p. 64.

1992 Khasagtina; Bengtson, p. 1030.

2000 Khasagtina; Williams et al., p. 214.

Type species. Khasagtina primaria Ushatinskaya, 1987, Tommotian (Tannuella gracilis Zone), Salaany-Gol Rivulet, Mongolia.

Diagnosis. See Williams et al. (1997).

Khasagtina sp.

Figure 18.6-13

Material. Two phosphatic internal molds including USTL1234/10.

Distribution. Section K2, sample $\mathrm{K} 2 /{ }_{12 \mathrm{~s}}$; Section $\mathrm{K} 3$, sample $\mathrm{K} 3 \mathrm{~T} / 2 \mathrm{e}$.

Description. The internal mold of the dorsal valve is cap-shaped, up to $1330 \mu \mathrm{m}$ long, $1835 \mu \mathrm{m}$ wide, and $755 \mu \mathrm{m}$ high (height/length ratio of 4/7). The aperture is oval in outline (laterally elongate; Figure 18.6). The subapical apertural margin is straight in dorsal view (Figure 18.6), with deep sinus in posterior view (Figure 18.9), short compared to the lateral and anterior apertural margins. The sinus is equilateral triangle in shape (Figure 18.9). The lateral and anterior apertural margins are curved in dorsal view (Figure 18.6). The apex lies in the plane of symmetry (Figure 18.6). It is shifted to the articulation side of the valve (Figure 18.6, 18.810). The dorsal field is slightly convex to almost straight in lateral view (Figure 18.8, 18.10). The lateral fields are straight in anterior/posterior view (Figure 18.7, 18.9). The subapical field (the surface under the apex) presents a groove running parallel to the subapical apertural margin (Figure 18.6, $18.9,18.12$, and arrow in 18.13). The surface of the internal molds displays radial ribs originating at the apex (Figure 18.6, 18.11). In the marginal area, the ribs are separated from each other by an average distance of $150 \mu \mathrm{m}$ (Figure 18.11).

Discussion. Kerber's (1988) specimens referred to as "Brachiopode gen. and sp. indet." display the same arrangement of radial ribs as those described in the present specimens. The latter may correspond to the same species as Kerber's "Brachiopode gen. and sp. indet.," but lack the peculiar structure interpreted as a pseudointerarea by Kerber (1988), probably due to breakage. The vascula lateralia and the muscle insertion scars are not visible in the present specimens but were present on Kerber's (1988) specimens (pl. 9, fig. 10). Therefore, the morphological traits of the specimens described herein (especially the furrow below the apex) and the paired muscle scars on "Brachiopode gen. and sp. indet." allow an assignment to the brachiopod genus Khasagtina Ushatinskaya, 1987. It also shares morphological similarities with Kundatella Aksarina in Aksarina and Pelman, 1978 (radial ribs and general shape). However, the subapical field in Kundatella is simply concave, whereas a groove runs parallel to the subapical apertural margin in the subapical field of the specimens studied herein.

\section{Phylum uncertain Class HYOLITHA Marek, 1963}

Discussion. The assignment of the class Hyolitha to the phylum Mollusca is still debated. They are either considered molluscs by Sysoev (1960), Marek (1963), Marek and Yochelson (1964), Missarzhevskiy in Rozanov et al. (1969), Marek and Yochelson (1976), Dzik (1978), Malinky (1987), and Kruse (1997) or a distinct phylum by Runnegar et al. (1975), Valkov et al. (1983), and Pojeta (1987). Therefore no phylum assignment is suggested herein.

Order ORTHOTHECIDA Marek, 1966

Family CIRCOTHECIDAE Missarzhevsky in

Rozanov et al., 1969

Genus CONOTHECA Missarzhevsky in Rozanov et al., 1969 
1969 Conotheca Missarzhevsky in Rozanov et al., 1969, p. 112.

1989 Conotheca; Missarzhevsky, p. 157.

1990 Conotheca; Bengtson et al., p. 213.

1981 Simplotubus Singh and Shukla, 1981, p. 163.

1989 Paracircotheca Qian, 1989, p. 72.

1996 Conotheca; Landing and Bartowski, p. 756.

2004 Conotheca; Malinky and Skovsted, p. 570.

2010 Conotheca; Parkhaev and Demidenko, p. 931.

Type species. Conotheca mammilata Missarzhevsky in Rozanov et al., 1969. Lower Cambrian, Tommotian (Dokidocyathus leanicus-Marjatheca tumefacta Zone), middle course of the Lena River, Churan village, Siberian Platform, Russian Federation.

Emended diagnosis. Conchs with circular crosssection and straight aperture; weak transverse elements of sculpture on the exterior; blunt apical part. Operculum seldom preserved with possible cardinal processes, clavicle-like tubules and circular ridges on interior (emended after Bengtson et al., 1990 and Malinky and Skovsted, 2004).

Discussion. The Genus Conotheca is considered an orthothecid hyolith because most of the species assigned to the genus exhibit opercula with cardinal processes and clavicle-like tubules along with the circular to oval cross-section, which are diagnostic characters of the order Orthothecida, and they lack the ventral ligula of the other hyolith order, the Hyolithida.

The type genus Conotheca mammilata Missarzhevsky in Rozanov et al., 1969 was not described with an operculum. Consequently, the diagnosis of the genus Conotheca Missarzhevsky in Rozanov et al., 1969 does not include an operculum. Subsequent specimens displaying opercula were attributed to Conotheca (e.g., C. australiensis Bengtson, 1990). Bengtson (1990) consequently considered the presence of an operculum with possible cardinal processes and clavicle-like tubules a diagnostic character of the genus. However, the presence or absence of an operculum associated with the conch greatly depends on preservational bias thus it is specified in the herein emended diagnosis.

Conotheca subcurvata (Yu, 1974)

Figure 19.1-30

1941 Hyolithes sp. type C: Wang, p. 69.
1974 Circotheca maidipingensis, Yu, 1974, p. 112, pl. 44, figs. 1-5.

1974 Circotheca subcurvata Yu, 1974, p. 111, pl. 44 , figs. 6-8.

1978a Circotheca longiconica Qian, 1978a, p. 9, pl. 1, figs. 3, 9.

1978a Circotheca multisulcata Qian, 1978a, p. 8, pl. 1, figs. 7,8 .

1978a Circotheca nana Qian, 1978a, p. 10, pl. 2, fig. 4.

1978b Circotheca nana; Qian, p. 132, pl. 14, figs. 2, 3.

1978a Circotheca obesa Qian, 1978a, p. 8, pl. 1, figs. 1, 2.

1978b Circotheca obesa; Qian, p. 132, pl. 14, figs. 4, 5.

1978a Circotheca subcurvata; Qian, p. 11, pl. 2, fig. 10.

1978b Circotheca subcurvata; Qian, p. 132, pl. 14, fig. 7.

1978b Conotheca mammilata Missarzhevsky in Rozanov et al.; Qian, p. 133-134, pl. 15, figs. 6, 14.

1979 Circotheca subcurvata; Qian et al., pl. 1, fig. 2.

1979 Circotheca ex gr. multisulcata; Qian et al., pl. 1, fig. 3.

1979 Circotheca longiconica; Qian et al., pl. 1, fig. 4.

1980a Circotheca longiconica; Jiang, pl. 1, figs. 6, 7, 22, 30-33.

1980 Circotheca longiconica; Luo et al., pl. 1, fig. 1.

1980a Circotheca multisulcata; Jiang, pl. 1, figs. 8, 10, 23.

1980a Circotheca nana; Jiang, pl. 1, fig. 17.

1980 Circotheca nana; Yin et al., 161, pl. 15, fig. 11.

1980 Circotheca subcurvata; Yin et al., p. 160, pl. 15, figs. 18, 19.

1980a Circotheca subcurvata; Jiang, pl. 1, fig. 15.

1980 Circotheca subcurvata; Chen and Zhang, pl. 2, figs. 1, 4.

1980a Conotheca absidata Qian and Jiang in Jiang, 1980a, p. 118, pl. 1, fig. 18.

1982 Circotheca subcurvata; Ding et al., pl. 1, fig. 7 . 


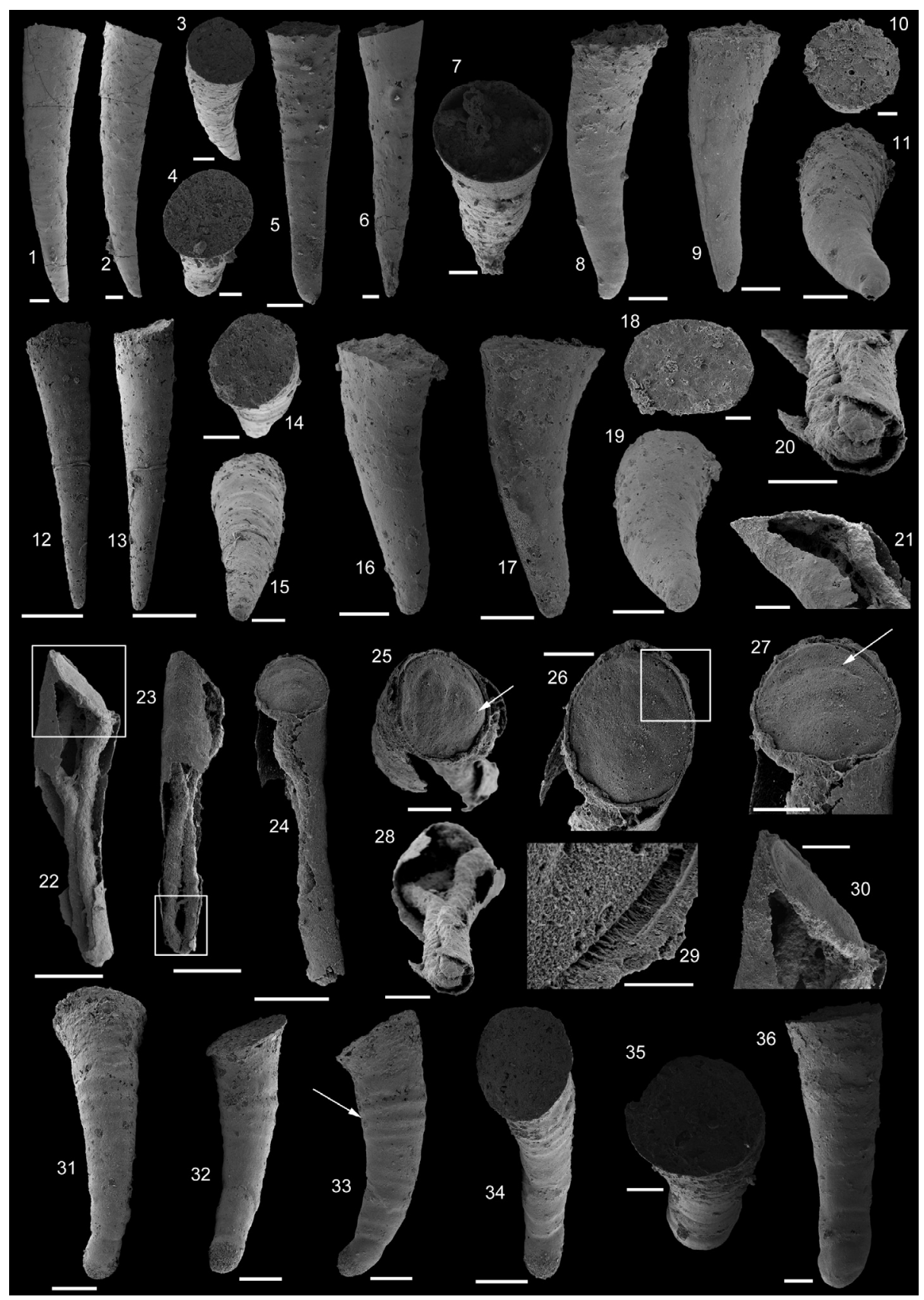

FIGURE 19. 1-30. Conotheca subcurvata (Yu, 1974). 1-3. USTL1261/2: 1, 2. Longitudinal views; 3. Apertural view. 45. USTL1210/9: 4. Longitudinal view; 5. Apertural view. 6-7. USTL1221/6: 6. Longitudinal view; 7. Apertural view. 811. USTL1253/1: 8, 9. Longitudinal views; 10. Apertural view; 11. Apical view. 12-15. USTL1264/3: 12, 13. Longitudinal views; 14. Apertural view; 15. Apical view. 16-19. USTL1253/2: 16, 17. Longitudinal views; 18. Apertural view; 19. Apical view. 20-30. USTL1251/13: 20. Detail of apical part of preserved digestive track; 21 . Detail of apertural part of preserved digestive track with operculum; 22. Longitudinal view of broken internal coating with visible digestive track, square shows location of 21 and 30; 23. Longitudinal view of broken internal coating with visible digestive track, square shows location of 20; 24 . Longitudinal view; 25. Apertural view, arrow shows eccentric apex of operculum; 26. View of the operculum, square shows location of 29; 27. Apertural view, arrow shows faint concentric depressions between apex and abapical apertural margin; 28. Apical view with digestive track visible; 29 . Detail of apertural margin; 30. Lateral view of operculum. 31-36. Paragloborilus subglobosus He in Qian, 1977. 31-34. USTL1221/7: $31,32$. Longitudinal views; 33. Longitudinal view, arrow shows annulations; 34. Apertural view. 35-36. USTL1222/10: 35. Apertural view; 36. Longitudinal view. Scale bars equal: 29, $50 \mu \mathrm{m} ; 4,6,7,10,18,35,36,100 \mu \mathrm{m} ; 1$-3, 5, 8, 9, 11, 1417, 19-21, 25-28, 30-34, $200 \mu \mathrm{m} ; 12,13,22-24,500 \mu \mathrm{m}$. 
1982 Circotheca longiconica; Luo et al., p. 165, pl. 13, fig. 2.

1982 Circotheca obesa; Qian, p. 214, pl. 56, fig. 10.

1982 Circotheca obesa; Luo et al., p. 165, pl. 13, fig. 2, 3.

1982 Conotheca absidata; Luo et al., p. 165, pl. 13, fig. 1.

1982 Conotheca dahaiensis Jiang in Luo et al., 1982, p. 165, pl. 13, figs. 4-6.

1983 Conotheca dahaiensis; Azmi and Pancholi, p. 368 , pl. 1, fig. 3 .

1983 Conotheca cf. C. dahaiensis; Azmi and Pancholi, p. 392, pl. 8, fig. 3.

1983 Circotheca sp. 1; Bhatt et al., pl. 1, fig. 2.

1984 Circotheca longiconica; Chen, pl. 1, fig. 5.

1984 Circotheca longiconica; Xing et al. 1984, pl. 25, figs. 29-30.

1984 Circotheca longiconica; Luo et al., pl. 7, figs. 8, 11.

1984 Circotheca multisulcata; Luo et al., pl. 7, fig. 7.

1984 Circotheca nana; Chen, p. 53, pl. 1, fig. 4, 5, 21.

1984 Circotheca obesa; Chen, pl. 1, fig. 4.

1984 Circotheca obesa; Luo et al. 1984: pl. 7, fig. 12.

1984 Circotheca obesa; Xing et al. 1984, pl. 20, figs. 26-28, pl. 25, figs. 29, 30, 31, 32.

1984 Circotheca subcurvata; Xing et al., pl. 20, figs. 1-4, pl. 25, figs. 13, 14.

1984 Circotheca subcurvata; Xiao and Zhou, p. 144, pl. 2, figs. $3,4$.

1984 Contheca [sic] absidata; Luo et al. 1984: pl. 7, figs. 9, 10.

1984 Conotheca maidipingensis (Yu); Qian and Yin, pl. 1, figs. 5, 6.

1984 Conotheca maidipingensis; Wang et al. 1984: pl. 3, fig. 2, 3.

1984 Conotheca cf. mammilata; Qian and Yin, pl. 1, figs. 1-4, 9 .

1985 Conotheca absidata; Qian and Zhang, p. 5, pl. 1, figs. 15, 18, pl. 3, fig. 3 .

1985 Circotheca obesa; Bhatt et al., p. 95, pl. 1, figs. 3, 3a, 4, 4a, 7, 7a.
1988 Circotheca sp.; Kerber, p. 151, pl. 1, figs. 23-25.

1988 Circotheca absidata (Qian and Jiang); Kerber, p. 149, fig. 11 , pl. 1 , figs. 10, 11, ?1216 , non figs. 17-22 [recte helcionelloid molluscs].

1989 Paracircotheca zhaojiabaensis Qian, 1989, p.73, text-fig. 12, pl. 9, figs. 1-16; pl. 76 , figs. 7,8 , pl. 77 , figs. 4,5 .

1989 Conotheca subcurvata (Yu); Qian and Bengtson, p. 127, text-fig. 85

1989 Conotheca subcurvata; Qian, p. 122, pl. 4, figs. $1-8,11,12,17-19$, pl. 6 , figs. $4-7,11$, pl. 10 , figs. 1,2 , pl. 74 , fig. 10 , pl. 75 , fig. 9 , pl. 76 , figs. $1-5$, pl. 78 , fig. 2 , non pl. 4 , figs. 13, 14 [recte Conotheca rotunda].

2001 Conotheca maidipingensis (Yu); Zhu et al., text-figs. 5.7, 5.9, 5.16.

2010 Conotheca subcurvata; Parkhaev and Demidenko, p. 933, 935, pl. 30, figs. 1-10.

Material. Hundreds of phosphatic internal molds and dozens of internal coatings including illustrated specimens USTL1221/6, USTL1251/13, USTL1253/1, USTL1253/2, USTL1261/2, and USTL1264/3.

Distribution. Section $K 2$, samples $K 2 / 3 b, K 2 / 4 b$, $\mathrm{K} 2 /_{6}, \mathrm{~K} 2 /_{7 \mathrm{e}}, \mathrm{K} 2 /_{8 \mathrm{a}}, \mathrm{K} 2 /_{9 \mathrm{a}}, \mathrm{K} 2 /_{10 \mathrm{a}}, \mathrm{K} 2 /_{12 \mathrm{a}}, \mathrm{K} 2 /_{12 \mathrm{k}}$, $\mathrm{K} 2 /{ }_{12 \mathrm{~m}}, \mathrm{~K} 2 /{ }_{120}, \mathrm{~K} 2 /{ }_{12 \mathrm{~s}}, \mathrm{~K} 2 /{ }_{13}, \mathrm{~K} 2 /{ }_{14}$, and $\mathrm{K} 2 /{ }_{16}$; section $\mathrm{K} 3$, samples $\mathrm{K} 3 \mathrm{~T} / 2 \mathrm{c}, \mathrm{K} 3 \mathrm{~T} / 2 \mathrm{e}, \mathrm{K} 3 \mathrm{~T} / 3 \mathrm{a}, \mathrm{K} 3 \mathrm{~T} /$ 4a, $\mathrm{K} 3 /_{6}, \mathrm{~K} 3 \mathrm{~T} / 12, \mathrm{~K} 3 /{ }_{1}, \mathrm{~K} 3 \mathrm{~B} / 2, \mathrm{~K} 3 \mathrm{~B} /{ }_{3}, \mathrm{~K} 3 \mathrm{~B} / 4, \mathrm{~K} 3 \mathrm{~B} /$ 6 , $\mathrm{K} 3 \mathrm{~B} /{ }_{10}, \mathrm{~K} 3 \mathrm{~B} /{ }_{11}, \mathrm{~K} 3 \mathrm{~B} /{ }_{12} \mathrm{~K} 3 \mathrm{~B} /{ }_{13}, \mathrm{~K} 3 \mathrm{~B} /{ }_{14}$; section $\mathrm{K} 4$, samples $\mathrm{K} 4 / 2, \mathrm{~K} 4 /_{4 \mathrm{a}}, \mathrm{K} 4 / 4 \mathrm{~b}, \mathrm{~K} 4 / 7, \mathrm{~K} 4 / 8, \mathrm{~K} 4 / 9$, $\mathrm{K} 4 /{ }_{11}, \mathrm{~K} 4 /{ }_{14}, \mathrm{~K} 4 / 17, \mathrm{~K} 4 / 21, \mathrm{~K} 4 / 22, \mathrm{~K} 4 / 24$, and $\mathrm{K} 4 / 25$; section $\mathrm{K} 5$, samples $\mathrm{K} 5 / 2, \mathrm{~K} 5 / 3, \mathrm{~K} 5 \mathrm{~b} / 2, \mathrm{~K} 5 \mathrm{~b} / 3, \mathrm{~K} 5 \mathrm{~b} /$ 4, K5b/8, K5b/11, K5/12, K5/13, K5/16, K5/19, K5/25, $\mathrm{K} 5 /_{32}, \mathrm{~K} 5 /_{35}, \mathrm{~K} 5 /_{39}, \mathrm{~K} 5 /_{40}, \mathrm{~K} 5 /_{41}, \mathrm{~K} 5 / 42$, and $\mathrm{K} 5 / 45$.

Description. The narrow conical internal molds are straight (Figure 19.1-2, 19.5-6, 19.12-13) to slightly curved (Figure 19.8-9, 19.16-17). The cross-section and apertural margin are circular to slightly oval (Figure 19.3-4, 19.7, 19.10, 19.14, $19.18,19.26)$. The apertural margin is straight or almost straight and perpendicular to the longitudinal axis (Figure 19.1-2, 19.4-5, 19.12-13, 19.1617 ). The apical extremity is blunt (Figure 19.11, $19.15,19.19)$. The external surface of the internal molds is smooth, with low ribs or undulations (Figure 19.5). The angle of divergence is uniform through the entire length and ranges from 8 to $15^{\circ}$, the length between 1 to $2.7 \mathrm{~mm}$ and the diameter from 250 to $900 \mu \mathrm{m}$. Operculum is preserved in a 
single specimen, apparently slightly shifted within an internal coating of a conch (Figure 19.25-26). Its preservation is questionable, probably representing a phosphatic coating (?) of external surface or its replacement (Figure 19.24-27), even if absence of inner cardinal process may argue for the former type of preservation. The thickness of the operculum is estimated to about $20 \mu \mathrm{m}$ through its imprint on the conch (Figure 19.29). The operculum is strongly low conical (almost flat) with a faint eccentric apex (arrowed in Figure 19.25). Apex is about 1/4 from the cardinal(?) border to the ventral margin. Faint concentric depressions are identified between the apical part and the opposite apertural margin of the molds (arrowed in Figure 19.27), and the peripheral margin is bordered by a deep and narrow furrow. The operculum is associated with a partly broken conch, giving access to its internal morphology. However, neither inner processes nor clavicles are obvious (Figure 19.21-22, 19.30). A three-dimensional preserved digestive track along with important microbial infill is observed (Figure 19.20-23, 19.28).

Comparison. Conotheca subcurvata is extremely abundant in the Heraultia Limestone and is usually highly deformed (mostly laterally flattened). The very simple morphology of these cones makes their species assignment difficult to assess. Only a few characters are available for identification (mostly related to cross-section, aperture, apex, and operculum when present). The angle of divergence in $C$. subcurvata is uniform, which differs from C. mammilata Missarzhevsky in Rozanov et al., 1969. C. circumflexa Missarzhevsky in Rozanov et al., 1969 is characterised by a slightly helical growth component of the conch, which is absent in C. subcurvata. Most species are not based on the operculum morphology as they are rarely preserved articulated. Only $C$. australiensis Bengtson in Bengtson et al., 1990 and C. rotunda Qian et al., 2000 are characterised by the presence of cardinal processes and clavicle-like tubules on the inner surface of the operculum. One specimen of $C$. subcurvata described herein exhibits an articulated (slightly displaced) operculum (Figure 19.25-26, 19.29), but the significance of the absence of (preserved?) cardinal processes and tubules on its inner surface is questionnable. The specimens described herein differ from C. corniformis Mambetov in Missarzhevsky and Mambetov, 1981 and C. brevica Qian et al., 2001 in the much flatter operculum. C. shennongjiaensis Duan, 1984 has a very sharp apex which is blunter in C. subcurvata.
Discussion. Tens of specimens exhibit a phosphatised digestive tract (Figure 19.20-24, 19.28). A further palaeobiological and taphonomic investigation of those structures are out of the scope of this paper, but will be the scope of another communication (Devaere et al., submitted).

Other occurrences. China: Zhongyicun Member, Zhujiaqing Formation, Nemakit-Daldynian (Anabarites trisulcatus-Protoherzina anabarica Zone), Baizai and Xianfeng, Xundian County, Yunnan Province (Xing et al., 1984; Qian, 1989; Qian and Bengtson, 1989); Zhongyicun Member and Dahai Member, Zhujiaqing Formation, Nemakit-Daldynian to Tommotian (Anabarites trisulcatus-Protoherzina anabarica Zone to Watsonella crosbyi Zone), Dahai and Daibu, Huize County, Yunnan Province (Luo et al., 1982; Qian, 1989; Qian and Bengtson, 1989); Xiaowaitoushan Member and Zhongyicun Member, Yuhucun Formation, Nemakit-Daldynian (Anabarites trisulcatus-Protoherzina anabarica to Paragloborilus subglobosus-Purella squamulosa Zone), Meishucun, Jinning County, Yunnan Province (Xing et al., 1984; Luo et al., 1982, 1984); Maidiping Formation to Jiulaodong Formation, Nemakit-Daldynian to Atdabanian, (Anabarites trisulcatus-Protoherzina anabarica Zone to Sinosachites flabelliformis-Tannuolina zhangwentangi Assemblage Zone), Maidiping, Emei County, Sichuan Province (Yu, 1974; Xing et al., 1984; Qian, 1989; Qian et al., 1997); Xinli Member, Dengying Formation, Nemakit-Daldynian (Anabarites trisulcatus-Protoherzina anabarica Zone), Xinli, Nanjiang County, Sichuan Province (Steiner et al., 2004); Upper Member, Dengying Formation, Nemakit-Daldynian (Anabarites trisulcatus-Protoherzina anabarica and Paragloborilus subglobosus-Purella squamulosa Zone), Kuanchuanpu and Yuanjiaping, Ningqiang County, Shaanxi Province (Xing et al., 1984); Maolongjing Member and Gezhongwu Member, Dengying Formation, Nemakit-Daldynian (Anabarites trisulcatus-Protoherzina anabarica and to Paragloborilus subglobosus-Purella squamulosa Zone), Gezhongwu, Zhijin County, Guizhou Province (Xing et al., 1984; Qian and Yin, 1984); Dayan Member, Dengying Formation, Nemakit-Daldynian (Anabarites trisulcatusProtoherzina anabarica Zone), Dayan, Zhijing County, Guizhou Province (Qian and Yin, 1984); Kuanchuanpu Formation, Nemakit-Daldynian (Anabarites trisulcatus-Protoherzina anabarica Zone), Shatan and Shizhonggou, Nanjiang County, Sichuan Province (Steiner et al., 2004); Yanjiahe Formation, Nemakit-Daldynian (Anabarites trisulcatus-Protoherzina anabarica Zone), Gunzi'ao, 
Yanjiahe, Yangtze Gorge, Yichang County, Hubei Province (Guo et al., 2008); Huangshandong Formation, Nemakit-Daldynian to Tommotian (Anabarites trisulcatus-Protoherzina anabarica, Paragloborilus subglobosus-Purella squamulosa and Watsonella crosbyi zones), Tianzhushan, Songlingpo, Shipai, Hujingtan, Yangjiadun, Huangshandong, Shibei Xizhou, Sandouping, Yidouping, Longhushan, Beishuya and Baimuping, Yichang County, Hubei Province (Qian et al., 1979; Chen et al., 1981; Xing et al., 1983); Yanjiahe Formation, Nemakit-Daldynian (Anabarites trisulcatus-Protohertzina anabarica Zone), Jijiapo, Yichang County, Hubei Province (Chen, 1984); Lower Member, Taozichong Formation, Nemakit-Daldynian (Anabarites trisulcatus-Protoherzina anabarica Zone), Abazhai, Zhijing County, Guizhou Province (Qian and Yin, 1984).

India: Upper Krol (Krol D), Phosphorite Formation, Krol-Tal Succession, Nemakit-Daldynian (Anabarites trisulcatus-Protoherzina anabarica Zone), Durmala, Lesser Himalaya (Azmi and Pancholi, 1983).

Genus PARAGLOBORILUS Qian, 1977

1977 Paragloborilus Qian, 1977, p. 257.

1980 Paragloborilus; Yin et al., p. 165.

1981 Salanytheca Missarzhevsky, 1981, p. 21.

1983 Paragloborilus; Duan, p. 158.

1983 Paragloborilus; Qian and Zhang, p. 84.

1989 Paragloborilus; Qian and Bengtson, p. 128.

1989 Paragloborilus, Yue and He, p. 398.

Type species. Paragloborilus subglobosus $\mathrm{He}$ in Qian, 1977, Nemakit-Daldynian to Tommotian (Paragloborilus subglobosus-Purella squamulosa Zone to Watsonella crosbyi Zone), Maidiping, Emei County, Sichuan Province, China.

Diagnosis. See Qian and Bengtson (1989).

Discussion. Contrary to Conotheca, the hyolith affinity of this genus must be regarded as unproven because no operculum has ever been found associated with conchs.

Paragloborilus subglobosus He in Qian, 1977 Figure 19.31-36

1977 Paragloborilus subglobosus He in Qian, 1977, p. 257, pl. 1, figs. 13-15.

1979 Paragloborilus cf. subglobosus: Qian et al., p. 213, pl. 1, figs. 14-16.

1979 Paragloborilus subglobosum: Anonym, 1979, pl. 8, fig. 7.
1979 Paragloborilus subglobosus; Lu, pl. 1, fig. 1.

1980 Paragloborilus subglobosus; Yin et al., p. 165, pl. 15, figs. 4, 5.

1981 Paragloborilus subglobosus; Xiang et al., pl. 1, fig. 1.

1982 Ovalitheca glabella Sysoev; Luo et al., p. 174, pl. 15, figs. 13, 14.

1982 Paragloborilus subglobosus; Luo et al., p. 167, pl. 13, figs. 19, 20.

1984 Ovalitheca mongolica Sysoev: Luo et al., pl. 7, figs. 14, 15.

1984 Paragloborilus subglobosus; Luo et al., pl. 7, fig. 18.

1984 Paragloborilus subglobosus; Xing et al., pl. 3, fig. 6; pl. 25, figs. 15, 16.

1989 Paragloborilus sichuanensis Yue and He, 1989, p. 398, pl. II, figs. 9-13.

1989 Paragloborilus subglobosus; Qian, p. 125, pl. 6, figs. 8-10, pl. 81, fig. 1.

1989 Paragloborilus subglobosus; Qian and Bengtson, p. 128, fig. 86.

2010 Paragloborilus subglobosus; Parkhaev and Demidenko, p. 935, 937, pl. 31, fig. 5.

Material. Nine phosphatic internal molds including illustrated specimens USTL1221/7 and USTL1222/ 10.

Distribution. Section $K 2$, samples $K 2 / 3 m, K 2 / 4 b$, $\mathrm{K} 2 / 8 \mathrm{a}, \mathrm{K} 2 /{ }_{10 \mathrm{a}}, \mathrm{K} 2 /{ }_{12 \mathrm{~m}}, \mathrm{~K} 2 /{ }_{12 \mathrm{~s}}, \mathrm{~K} 2 / 14$, and $\mathrm{K} 2 / 16$.

Description. The narrow, conical internal molds (angle of divergence from 8 to $14^{\circ}$ ) are straight (Figure 19.35) to slightly curved (Figure 19.31) and oval (Figure 19.34) to circular (Figure 19.36) in cross-section. They are up to $1400 \mu \mathrm{m}$ in length and up to $500 \mu \mathrm{m}$ in diameter at the aperture. The apical part of the cones is bulbous (Figure 19.31$33,19.35)$ and usually makes a slight angle with the rest of the tube (Figure 19.31). In some specimens, the apical spherical part is separated from the rest of the tube by a slight constriction (Figure 19.31), but the transition between the apex and the rest of the cone can be progressive and indistinct (Figure 19.36). Transverse annulations (Figure 19.31), more or less distinctly observable, are present and separated from each other by a distance of about $50-100 \mu \mathrm{m}$. The annulations are parallel to the apertural margin and more closely spaced in inner part of the curvature, when present (arrowed in Figure 19.33). The apertural margin is 
perpendicular to the longitudinal axis (Figure 19.31, 19.35).

Comparison. Paragloborilus subglobosus differs from P. circulatus Qian and Zhang, 1983 (syn. P. condensatus Duan, 1984; P. tenuis Duan, 1984; P. songbaiensis Duan, 1984 and $P$. pygmeus Duan, 1984) in its less curved and less expanded shell and by the absence of two layers in the shell. Moreover, the shell surface of $P$. circulatus Qian and Zhang, 1983 is ornamented by very fine and numerous transverse striations occassionally crossed by longitudinal lines, absent in $P$. subglobosus. The main difference between $P$. subglobosus and $P$. capitatus Jiang in Luo et al., 1982 lies in the form of the apex. The apex of $P$. subglobosus is much larger than the end diameter of the shell and it is highly bulbous. The apex of $P$. capitatus is smaller than the rest of the shell and sharper. $P$. papillaris Missarzhevsky, 1981 (syn. P. ribis Qian, 1989 ) is distinguished from $P$. subglobosus by the presence of more prominent, rounded and closely spaced transverse ribs (entirely ondulated shell). Finally, P. subglobosus differs from $P$. sichuanensis Yue and He, 1989 by the complete absence of transverse ribs.

Other occurrences. China: Maidiping Member, Tongying Formation, Nemakit-Daldynian to Tommotian (Paragloborilus subglobosus-Purella squamulosa Zone to Watsonella crosbyi Zone), Maidiping and Gaoqiao, Emei County (Qian, 1977, 1989; Yin et al., 1980; Xing et al., 1984; Yue and $\mathrm{He}, 1989$; Steiner et al., 2007) and Kuanchuanpu Formation, Nemakit-Daldynian (Paragloborilus subglobosus-Purella squamulosa Zone with reworked elements of the Anabarites trisulcatusProtoherzina anabarica Zone), Shatan, Nanjiang County (Steiner et al., 2007), Sichuan Province; Kuanchuanpu Formation, Nemakit-Daldynian to Tommotian (Paragloborilus subglobosus-Purella squamulosa Zone to Watsonella crosbyi Zone), Yuanjiaping, Ningqiang County, Shaanxi Province (Chen et al., 1975; Xing et al., 1984); Zhongyicun Member and Dahai Member, Zhujiaqing Formation, Nemakit-Daldynian to Tommotian (Paragloborilus subglobosus-Purella squamulosa Zone to Watsonella crosbyi Zone), Meishucun, Jinning County (Luo et al., 1982, 1984; Qian, 1989; Parkhaev and Demidenko, 2010), Xianfeng, Xundian County, (Qian, 1989; Qian and Bengtson, 1989), Xiaotan, Yongshan County (Li and Xiao, 2004), and Dahai, Huize County (Luo et al., 1982; Qian et al., 1996), Yunnan Province; Huangshandong Member, Tongying Formation, Nemakit-Dadlydnian to Tommotian (Paragloborilus subglobosus-Purella squa- mulosa Zone to Watsonella crosbyi Zone), Liantuo, Tianzhushan and Yangjiadun Yichang County (Qian et al., 1979; Qian, 1989) and Tianzhushan Member, Dengying Formation, Nemakit-Daldynian to Tommotian (Paragloborilus subglobosus-Purella squamulosa Zone to Watsonella crosbyi Zone), Huangjiatang, Yichang County (Xing et al., 1984), Hubei Province.

\section{Family GLOBORILIDAE Sysoev, 1957}

Genus COBBOLDIELLA Kerber, 1988

1988 Cobboldiella Kerber, 1988, p.156.

Type species. Cobboldiella transalpina Kerber, 1988; Tommotian Stage (Watsonella crosbyiOelandiella korobkovi Interval Zone), Saint Geniès de Varensal, Hérault, France.

Emended diagnosis. The spiny conical shells are dorso-ventrally bilaterally symmetrical or curved toward either right or left side. The shells are ventrally curved and taper toward the apex. The subquadrate to subrectangular aperture is almost straight. The weakly concave ventral side can be limited by marginal ridges. The apex is bulbous. Growth lines lie transversally (emended after Kerber, 1988).

Discussion. The genus Cobboldiella described herein is considered to belong to the family Globorilidae Sysoev, 1957 based on its subrectangular cross-section and the presence of a bulbous apex.

\section{Cobboldiella transalpina Kerber, 1988}

Figure 20.1-9

1988 Cobboldiella transalpina Kerber, 1988, p. 157, pl. 3, figs. 1-5.

Material. About 20 phosphatic internal molds with occassional fragments of external molds or phosphatised endolithic-microborers, including USTL1211/2, USTL1217/19, and USTL1220/3.

Distribution. Section $\mathrm{K} 2$, samples $\mathrm{K} 2 / 6$ and $\mathrm{K} 2 / 16$; section $\mathrm{K} 3$, samples $\mathrm{K} 3 \mathrm{~B} / 4, \mathrm{~K} 3 \mathrm{~B} / 6, \mathrm{~K} 3 \mathrm{~T} / 2 \mathrm{c}, \mathrm{K} 3 \mathrm{~T} / 2 \mathrm{e}$, $\mathrm{K} 3 \mathrm{~T} / 3 \mathrm{a}, \mathrm{K} 3 \mathrm{~T} / 4 \mathrm{a}$; section $\mathrm{K} 4$, samples $\mathrm{K} 4 / 4 \mathrm{a}$ and $\mathrm{K} 4 /$ 7; section $\mathrm{K} 5$, samples $\mathrm{K} 5 \mathrm{~b} / 2, \mathrm{~K} 5 \mathrm{~b} / 8, \mathrm{~K} 5 /{ }_{12}, \mathrm{~K} 5 / 13$ $\mathrm{K} 5 / 25$, and $\mathrm{K} 5 / 45$.

Description. The conical conchs are almost bilaterally symmetrical (Figure 20.1, 20.6). The ventral side (following Kerber, 1988) is flat to concave and the concavity increases toward the aperture (Figure 20.1, 20.5). The dorsal side (following Kerber, 1988 ) is broadly convex (Figure 20.2). The transverse section and the aperture are subcircular to subrectangular (Figure 20.3, 20.6, 20.9). The transition from the ventral to the dorsal side is sharp and marked by a ridge (Figure 20.1). The aperture is perpendicular to the longitudinal axis but with the 


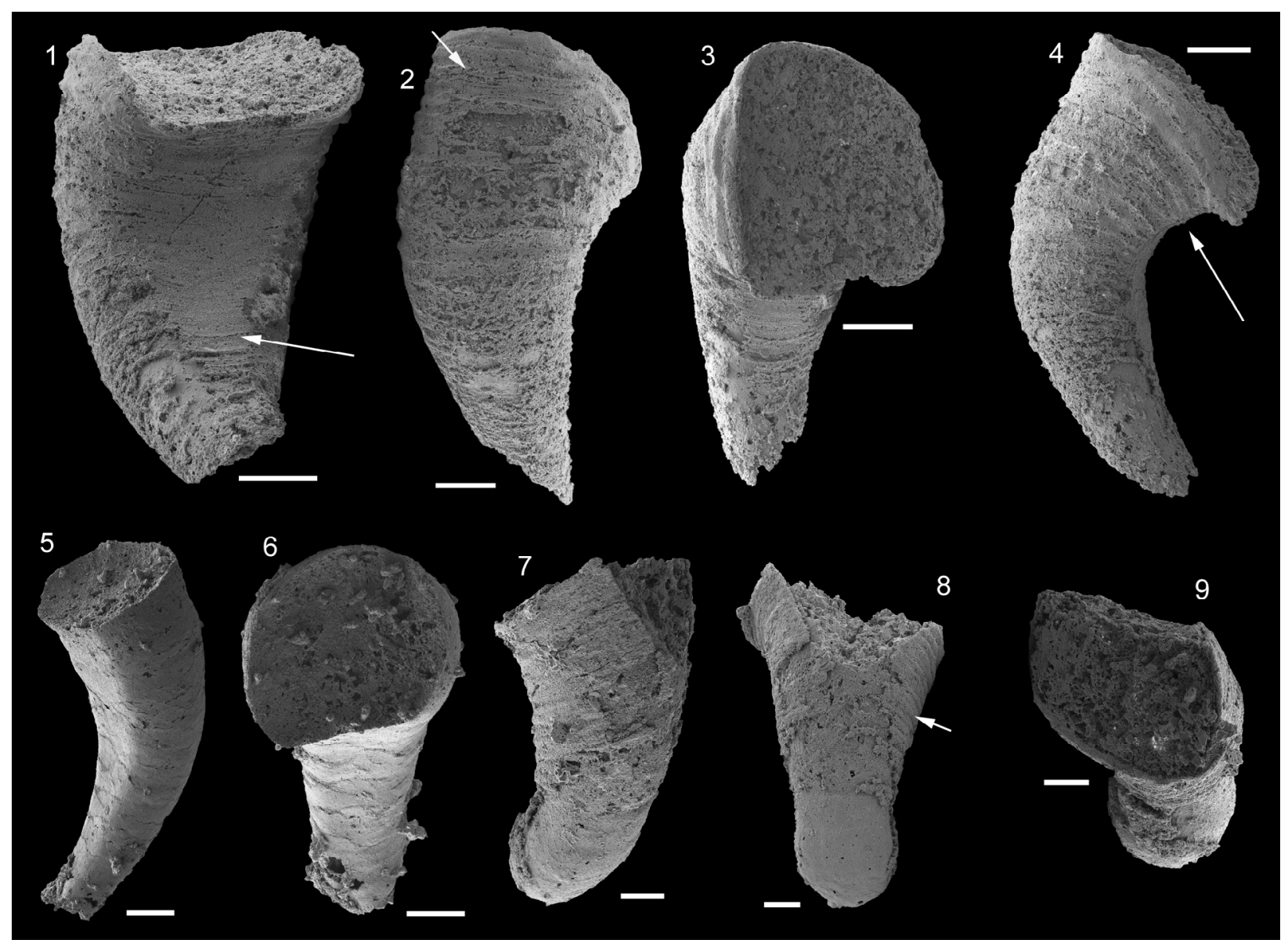

FIGURE 20. Cobboldiella transalpina Kerber, 1988. 1-4. USTL1217/19: 1. Ventral view, arrow points ventral fine growth lines; 2. Dorsal view, arrow points dorsal transverse rib; 3. Apertural view; 4. Lateral view, arrow shows lateral transverse ribs. 5-6. USTL1211/2: 5. Ventro-lateral view of internal mold; 6. Apertural view. 7-9. USTL1220/3: 7. Lateral view of conch with embryonic chamber preserved; 8. Dorsal view, arrow shows dorsal transverse ribs; 9 . Apertural view. Scale bars equal: 1-6, $200 \mu \mathrm{m} ; 7-9,100 \mu \mathrm{m}$.

ventral part slightly inclined toward the apical end (Figure 20.4). The conchs are slightly curved toward the ventral side (Figure 20.4-5, 20.7). The apex is globular and most probably represents an embryonic chamber (Figure 20.7-8). The transition from the apex to the rest of the conch is progressive, and the apex makes a slight angle with the remaining of the conch (Figure 20.7). Internal molds are smooth (Figure 20.5-6), whereas the external coatings exhibit transverse ribs (arrowed in Figure 20.2, 20.4, and 20.8) on the dorsal side and fine growth lines (arrowed in Figure 20.1) on the ventral side.

Comparison. The cross-section of C. transalpina is subrectangular and differs from the circular to oval cross-section of Globorilus globiger (Saito, 1936).
Other occurrences. Occurrences of Cobboldiella transalpina Kerber, 1988 outside of Montagne Noire are not reported.

Tubular problematics

Genus PSEUDORTHOTHECA Cobbold, 1935

1935 Pseudorthotheca Cobbold, 1935, p. 27.

1962 Pseudorthotheca; Fisher, p. 133.

1966 Pseudorthotheca; Rozanov and Missarzhevsky, p. 89-90.

1988 Pseudorthotheca; Kerber, p. 152.

Type species. Pseudorthotheca acuticincta Cobbold, 1935, Tommotian (Watsonella crosbyi-Oelandiella korobkovi Interval Zone), Saint Geniès de Varensal, Hérault, France.

Emended diagnosis. Annulated tapering tubes of circular or oval section, straight or gently curved. Angle of divergence ranging from 8 to $20^{\circ}$. Annula- 
tions marked by fine striae or by raised ribs, sharply defined or faint. Aperture transverse, in one plane usually, at right angles to the axial line. Operculum unkown (emended after Cobbold, 1935).

Remarks. Several annulate tubes are known from lower Cambrian deposits elsewhere. They can be found among members of the genera Hyolithellus (e.g., Hyolithellus isiticus Missarzhevsky in Rozanov et al., 1969), Colelolella (e.g., Colelolella billingsi Syssoiev, 1962) and Ovalitheca (e.g., Ovalitheca multicostata Qian, 1977). They all exhibit a very narrow angle of divergence: they are almost not tapering, and the tubes are open at both ends. Therefore, the genus Pseudorthotheca clearly differs from Hyolithellus, Coleolus and Colelolella by its wide angle of divergence resulting in a closed cone. According to their narrow angle of divergence, Pseudorthotheca costata and $P$. bistriata are considered here outside the genus Pseudorthotheca and might be regarded as Hyolithellus.

Pseudorthotheca rotundicincta Cobbold, 1935

Figure 21.1-13

1935 Pseudorthotheca rotundicincta Cobbold, 1935 , p. 28, pl. 3, fig. 3.

1935 Pseudorthotheca filosa Cobbold, 1935, p. 29, pl. 3, figs. 10-11.

1967 Pseudorthotheca danica Poulsen, 1967, p. 36, pl. 7, figs. 3-4.

1977 Lophotheca multicostata Qian, 1977, p. 258, pl. 1, figs. 6,7 .

1978a Lophotheca costellata Qian, 1978a, p. 32, pl. 1, figs. 11, 13.

1978b Lophotheca uniforma Qian, 1978b, p. 128, pl. 13, fig. 3.

1978b Lophotheca multicostata; Qian, p. 129, pl. 13, figs. 4, 5, 7, 14.

1978b Lophotheca costellata; Qian, p. 128, pl. 13, figs. $1,6,8$.

1979 Lophotheca costellata; Qian et al., pl. 1, figs. $11,13$.

1980 Ovalitheca multicostata (Qian); Chen and Zhang, pl. 2, fig. 13.

1981 Pseudorthotheca filosa; Missarzhevsky and Mambetov, p. 47, pl. IV, figs. 8, 10.

1988 Pseudorthotheca rotundicincta; Kerber, p. 153, pl. 2, figs. 7-10.

Material. About 30 slightly broken phosphatic internal molds (tip missing) and 2 complete specimens, including USTL1231/1, USTL1240/9, and USTL1258/5.

Distribution. Section $\mathrm{K} 2$, samples $\mathrm{K} 2 / 3 \mathrm{~b}, \mathrm{~K} 2 /_{3 \mathrm{~m}}$, $\mathrm{K} 2 /_{4 \mathrm{~b}}, \mathrm{~K} 2 /_{6}, \mathrm{~K} 2 /_{13}, \mathrm{~K} 2 /_{14}$, and $\mathrm{K} 2 /_{16}$; section $\mathrm{K} 3$, samples $\mathrm{K} 3 /{ }_{1}, \mathrm{~K} 3 \mathrm{~B} / 2, \mathrm{~K} 3 \mathrm{~B} / 4, \mathrm{~K} 3 \mathrm{~B} / 6, \mathrm{~K} 3 \mathrm{~T} / 2 \mathrm{e}$, and $\mathrm{K} 3 \mathrm{~T} / 3 \mathrm{a}$; section $\mathrm{K} 4$, sample $\mathrm{K} 4 /_{4 a}$; section $\mathrm{K} 5$, samples $\mathrm{K} 5 \mathrm{~b} / 3, \mathrm{~K} 5 \mathrm{~b} / 8, \mathrm{~K} 5 / 12, \mathrm{~K} 5 / 13, \mathrm{~K} 5 /_{32}$, and $\mathrm{K} 5 / 40$.

Description. The narrow conical conchs are slightly curved (Figure 21.1, 21.5, 21.9-10, 21.12). The cross-section and apertural margin are circular to oval (minimum diameter/maximum diameter ratio from 1 to 1/2; Figure 21.1-2). The apertural margin is straight or almost straight and perpendicular to the longitudinal axis (Figure 21.3, 21.5, 21.10). When preserved, the apical part is bluntly pointed (Figure 21.8-11). The external surface of the internal molds exhibits narrow (ca. $20 \mu \mathrm{m}$ ), sharp, transverse ribs (Figure 21.1-13). The space between ribs greatly varies all along the length of the conch, with a minimum of $30 \mu \mathrm{m}$ to a maximum of $380 \mu \mathrm{m}$ (Figure 21.3, 21.5-7). The ribs are generally parrallel to the apertural margin but run occassionally slightly sinusoidally on one side of the conch (arrowed in Figure 21.8). The angle of divergence is uniform through the entire length and ranges from 8 to $15^{\circ}$. The length varies between 1480 to $4500 \mu \mathrm{m}$ and diameter of the aperture from 250 to $900 \mu \mathrm{m}$.

Comparisons. Pseudorthotheca rotundicincta Cobbold, 1935 differs from $P$. acuticincta Cobbold, 1935 in its narrower, sharper, more closely and irregularly spaced ribs and by the bluntly pointed apex, instead of swollen one.

Other occurrences. Norretorp Formation, Atdabanian (Mobergella-Schmidtiellus mickwitzi Zone), Island of Bornholm, Denmark (Poulsen, 1967); Huangshandong Formation, Nemakit-Daldynian to Tommotian (Paragloborilus subglobosus-Purella squamulosa and Watsonella crosbyi zones), Tianzhushan, Yangjiadun, Shibei and Hujintan, Yichang County, Hubei Province, China (Qian, 1977; Qian, 1978a; Qian et al., 1979); Tianzhushan Member, Dengying Formation, Nemakit-Daldynian (Paragloborilus subglobosus-Purella squamulosa and Watsonella crosbyi zones), Songlinpo, Yichang County, Hubei Province, China (Chen and Zhang, 1980; Chen et al., 1981); Chulaktau Formation to Shabakty Formation, Tommotian to Atdabanian (Pseudorthotheca costata Zone to Rhombocorniculum cancelatum Zone), Aktugay, Kazakhstan (Missarzhevsky and Mambetov, 1981).

Pseudorthotheca acuticincta Cobbold, 1935 Figure 21.14-30 


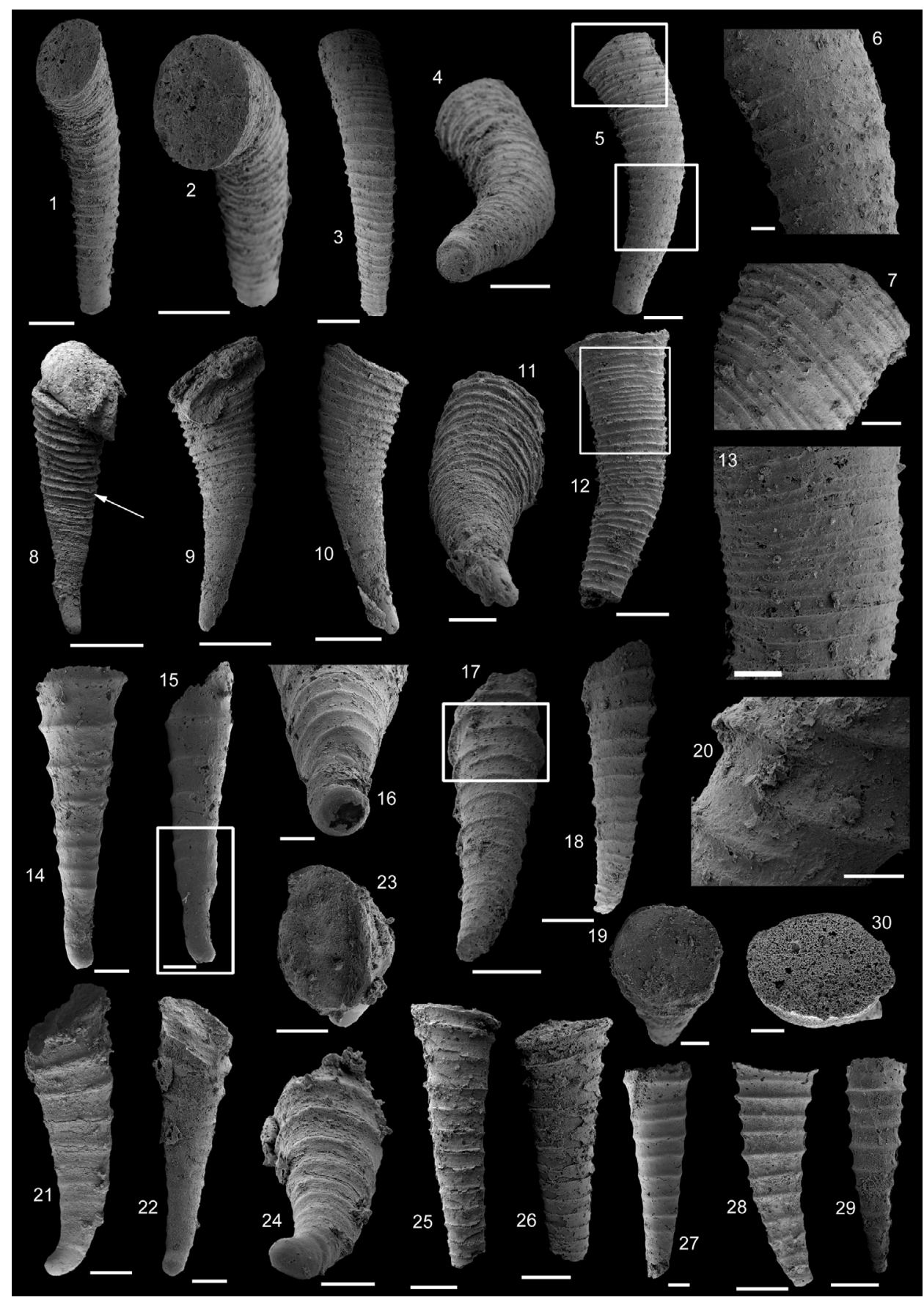

FIGURE 21. 1-13. Pseudorthotheca rotundicincta Cobbold 1935. 1-7. USTL1258/5: 1. Longitudinal view; 2. Apertural view; 3. Longitudinal view; 4. Apical view; 5 . Longitudinal view, lower square shows location of 6 , upper square shows location of 7; 6 . Detail of transverse ribs; 7. Detail of transverse ribs near the aperture. 8-11. USTL1240/9: 8. Longitudinal view, arrow shows sinusoidal transverse rib; 9, 10. Longitudinal views; 11 . Apical view with bluntly pointed apex. 12-13. USTL1231/1: 12. Longitudinal view, square shows location of 13; 13. Detail of sharp transverse ribs. 14-30. Pseudorthotheca acuticincta Cobbold 1935. 14-16. USTL1217/20: 14. Longitudinal view; 15. Longitudinal view, square shows location of 16; 16. Detail of swollen and round apex. 17-20. USTL1257/6: 17. Inclined longitudinal view, square shows location of 20; 18. Longitudinal view; 19. Apertural view; 20. Detail of discontinuous and shifted transverse rib. 21-24. USTL1253/10: 21, 22. Longitudinal views; 23. Apical view with swollen round apex; 24. Apertural view. 25-26. USTL1247/7: 25. Longitudinal view, internal mold with external coating; 26 . Longitudinal view, internal mold with partly preserved external coating. 27. USTL1221/5, specimen with low ribs. 28-30. USTL1229/2: $28,29$. Longitudinal view; 30. Apertural view. Scale bars equal: 6, 16, $100 \mu \mathrm{m} ;$ 7, 11, 13-15, 20-24, 19, 30, 200 $\mu \mathrm{m}$; 25-27, $300 \mu \mathrm{m} ; 1-5,8-10,12,17,18,28,29,500 \mu \mathrm{m}$. 
1935 Pseudorthotheca acuticincta Cobbold, 1935, p. 27, pl. 3, figs. 1-2.

1935 Pseudorthotheca obsoleta Cobbold, 1935, p. 28, pl. 3, fig. 4-5.

1966 Pseudorthotheca obsoleta; Rozanov and Missarzhevsky, p. 90, text-fig. 54.

1978b Pseudorthotheca bistriata Qian, 1978b, p. 131 , pl. 13 , figs. $11,12 a-b$, pl. 15 , figs.4, 5a-b.

1988 Pseudorthotheca acuticincta; Kerber, p. 153 , pl. 2, figs. $1-6$.

1988 Pseudorthotheca filosa; Kerber, p. 154, pl. 2, figs. 11-15.

1988 Pseudorthotheca perornata Kerber, 1988, p. 154 , pl. 2. figs. 16-17.

1989 Pseudorthotheca bistriata; Qian, p. 135, pl. 1 , fig. 13 , pl. 2 , figs. $1-4$, pl. 21 , figs. $7-9$, pl. 82, figs. $1-5$.

Material. About 70 slightly broken specimens (tip missing) and 2 complete specimens, including USTL1217/20, USTL1221/5, USTL1229/2, USTL1247/7, USTL1253/10, and USTL1257/6, preserved as phosphatic internal molds with partly preserved external coating.

Distribution. Section $\mathrm{K} 2$, samples $\mathrm{K} 2 / 3 \mathrm{~b}, \mathrm{~K} 2 / 3 \mathrm{~m}$, $\mathrm{K} 2 /_{4 \mathrm{~b}}, \mathrm{~K} 2 /_{6}, \mathrm{~K} 2 /_{7 \mathrm{e}}, \mathrm{K} 2 /_{10 \mathrm{a}}, \mathrm{K} 2 /{ }_{12 \mathrm{k}}, \mathrm{K} 2 /{ }_{12 \mathrm{~m}}, \mathrm{~K} 2 /{ }_{12 \mathrm{~s}}$, $\mathrm{K} 2 /{ }_{13}, \mathrm{~K} 2 /{ }_{14}$, and $\mathrm{K} 2 /{ }_{16}$; section $\mathrm{K} 3$, samples $\mathrm{K} 3 /{ }_{1}$, $\mathrm{K} 3 \mathrm{~B} / 2 \mathrm{a}, \mathrm{K} 3 \mathrm{~B} / 4, \mathrm{~K} 3 \mathrm{~B} / 14, \mathrm{~K} 3 \mathrm{~T} / 2 \mathrm{c}, \mathrm{K} 3 \mathrm{~T} / 2 \mathrm{e}, \mathrm{K} 3 \mathrm{~T} / 3 \mathrm{a}$, $\mathrm{K} 3 \mathrm{~T} / 4 \mathrm{a}$, and $\mathrm{K} 3 \mathrm{~T} / 6$; section $\mathrm{K} 4$, samples $\mathrm{K} 4 / 2, \mathrm{~K} 4 /$ 4a, $\mathrm{K} 4 / 9$ and $\mathrm{K} 4 /{ }_{17}$; section $\mathrm{K} 5$, samples $\mathrm{K} 5 / 2, \mathrm{~K} 5 / 3$, $\mathrm{K} 5 \mathrm{~b} / 2, \mathrm{~K} 5 \mathrm{~b} / 3, \mathrm{~K} 5 \mathrm{~b} / 4, \mathrm{~K} 5 /_{12}, \mathrm{~K} 5 /_{13}, \mathrm{~K} 5 /_{17}, \mathrm{~K} 5 / 19, \mathrm{~K} 5 /$ $32, \mathrm{~K} 5 / 40 \mathrm{~K} 5 / 41$, and $\mathrm{K} 5 / 45$.

Description. The narrow conical conchs are straight (Figure 21.14-15, 21.25-27) to slightly curved (Figure 21.17-18, 21.21, 21.24-25). The cross-section and apertural margin are circular (Figure 21.19) to slightly oval (minimum diameter/ maximum diameter ratio from $1 / 2$ to 1 ; Figure $21.23,21.30)$. When complete, the apertural margin is straight or almost straight and perpendicular to the longitudinal axis (Figure 21.14-15, 21.25$27,21.29-30)$. When preserved, the apical part is swollen and rounded (Figure 21.14-16, 21.21-22, 21.24). Both external surfaces of internal molds and external coatings exhibit large and high transversal ribs (Figure 21.14-18, 21.21-22, 21.25-29). Therefore, annulation of the shell is produced by folds of the shell instead of thickening. The spaces between the ribs are wide (ranging from 155 to 460 $\mu \mathrm{m})$. The ribs are generally parallel to the apertural margin but occassionally discontinuous and shifted
(Figure 21.17, 21.19). They are variably expressed, from sharp and high (Figure 21.18) to low (Figure 21.27), depending on the quality of preservation. The angle of divergence is uniform through the entire length and ranges from 8 to $15^{\circ}$. The length varies between 1500 to $5000 \mu \mathrm{m}$, and the diameter of the aperture is up to $1250 \mu \mathrm{m}$.

Comparison. The swollen and rounded apex of Pseudorthotheca acuticincta Cobbold, 1935 enables its differentiation from Pseudorthotheca rotundicincta Cobbold, 1935, which has a bluntly pointed apex. Moreover, the transversal ribs of $P$. acuticincta are larger, higher, and more remote from one another, clearly differing from the narrow, sharp, and closely spaced ribs of $P$. rotundicincta.

Other occurrences. Tommotian Stage, Lena River, Churan village, Siberian Platform, Russian Federation (Rozanov and Missarzhevsky, 1966); Huangshandong Formation, Nemakit-Daldynian to Tommotian (Paragloborilus subglobosus-Purella squamulosa Zone to Watsonella crosbyi Zone), Tianzhushan, Yangjiadun, Shibei and Hujintan, Yichang County, Hubei Province, China (Qian, 1978a; Qian, 1989).

Phylum, Class, Order and Family uncertain Genus PARACARINACHITES Qian and Jiang in Luo et al., 1982

1980 Paracarinachites [nom. nud.]; Jiang, 1980b, p. 91.

1982 Paracarinachites Qian and Jiang in Luo et al., 1982, p. 183.

1984b Luyanhaochiton Yu, 1984b, p. 25.

1984b Yangtzechiton Yu, 1984b, p. 24-25.

1987b Luyanhaochiton; Yu, 1987b, p. 122-124.

1987b Yangtzechiton; Yu, 1987b, p. 118-120.

1988 Paracarinachites; Kerber, 1988, p. 186.

1989 Paracarinachites; Qian and Bengtson, p. 49.

2010 Paracarinachites; Parkhaev and Demidenko, p. 911.

Type species. Paracarinachites sinensis, Qian and Jiang in Luo et al., 1982; Nemakit-Daldynian to Tommotian (Paragloborilus subglobosus-Purella squamulosa Zone), Yulu, Huize County, Yunnan Province, China.

Diagnosis. See Qian and Bengtson (1989).

Discussion. Parkhaev and Demidenko (2010) suggested that the genus Paracarinachites belongs to the family Zhijinitidae Qian, 1978, which groups the genera Cambroclavus, Carinachites, Isoclavus, Wushichites and Zhijinites. However, 
they do not provide any strong evidence of the phylogenetic relationships between Paracarinachites and any other genus of the Zhijinitidae. Moreover, Parkhaev and Demidenko (2010) point out that despite their gross similarities, Zhijinites and Paracarinachites differ in their sclerites arrangement: the body of Zhijinites is supposed to have been covered by solitary sclerites, whereas Paracarinachites consist either of independent but tightened sclerites or of a series of fused nail-like spines. The general organisation of Paracarinachites is also broadly similar to Cambroclavus sclerites by bearing an elongate spine but differ significantly in having a curved shield, whereas in Cambroclavus, the shield is clearly flat. Moreover, Cambroclavus also presents articulation facets, absent in the herein isolated segments of Paracarinachites. Therefore, we do not consider the genus Paracarinachites to belong to the family Zhijinitidae as suggested by Parkhaev and Demidenko (2010). Following Qian and Bengtson (1989), we consider that paracarinachitids and Zhijinitids could be related but their relationships must be further investigated. The establishment of the suprageneric parataxonomy of the unformal group paracarinachitid is therefore not possible.

Paracarinachites sinensis Qian and Jiang in Luo et al., 1982

Figure 22.1-20

1980 Carinachites spinatus Qian; Jiang, pl. 4, fig. 5.

1980 Carinachites spinatus; Luo et al., pl. 1, fig. 18.

1980 Paracarinachites sinensis Qian and Jiang [nom. nud.] in Luo et al., 1980, pl. 4, fig. 6.

1982 Paracarinachites sinensis Qian and Jiang in Luo et al., 1982, p. 183-184, text-fig. 55, pl. 17, fig. 17.

1982 Carinachites spinatus; Luo et al., p. 183, pl. 17, fig. 18.

1984 Paracarinachites columellatus Qian, 1984, p. 94, pl. 1, figs. 16, 23, 24.

1984 Paracarinachites sinensis; Jiang, pl. 3, fig. 10.

1984 Paracarinachites sinensis; Luo et al. 1984: pl. 11, figs. 12, 13.

1984 Paracarinachites sinensis; Qian, p. 94, pl. 1, figs. 26-28; pl. 2, figs. 14, 15.

1984a Yangtzechiton elongatus Yu, 1984a, pl. 1, fig. 1-7. 1984b Yangtzechiton elongatus; Yu, fig. 4a-e.

1987b Yangtzechiton elongatus; Yu, p. 120-122, pl. 8, fig.1-7; pl. 9, fig.1-3, 4? pl.10, fig. 12, pl. 11 , fig. $1-4$, pl. 12 , fig. $1-4$, pl. 14 , fig. 1-4.

1988 Paracarinachites sinensis; Kerber, p. 187, text-figs. 29, 30; pl. 11, figs. 1-12.

1989 Paracarinachites bispinosus, He and Xie, 1989, p. 115-116, pl. 1, figs. 13 and 15; non pl. 1, figs. 14 [recte unidentifiable remain].

1989 Paracarinachites sinensis; He and Xie, p. 115, pl. 1, figs. 8-12.

1989 Paracarinachites sinensis; Qian and Bengtson, p. 49, text-figs. 27, 28.

1989 Paracarinachites sinensis; Qian, p. 266, text-fig. 61 , pl. 44 , fig. 3 , pl. 45 , figs. 9 , 10 , pl. 48, figs. 1-3.

1990 Paracarinachites sinensis; Yu, p. 142, textfigs. 1c-1i.

1993 Paracarinachites sinensis; Yu, p. 312, pl. 1, figs. 7-18.

2001 Paracarinachites sinensis; Yu, figs. 3G3K, 4F-4P, 11.

Emended diagnosis. Paracarinachites species with narrow, spatula-like sclerites, curved up to about $90^{\circ}$.in sagittal plane, and with beak-shaped apical part. Outer side approximately semicircular in transverse profile. One single row of denticles along crest. Surface smooth or having chevronshaped growth lines with variably apically and abapically directed tips, each major growth increment having one denticle. The lateral margins with a flange (emended after Qian and Bengtson, 1989).

Discussion. The restudied material from Montagne Noire confirms the presence of a flange along the lateral margin of $P$. sinensis. The specimens of $P$. sinensis in Yu (2001) also exhibit a strongly developed flange (figs. 3G-K; $4 \mathrm{~F}-\mathrm{H}, \mathrm{J}$ ). As Qian and Bengtson (1989) already suggested that this structure might be originally present but not preserved in their specimens, the diagnosis of this species is emended herein in order to include this character.

Material. Eight complete to slightly broken phosphatic external coatings, including USTL1225/1, USTL1225/3, and USTL1228/6, and hundreds of phosphatic internal molds, including USTL1211/15. Distribution. Section $\mathrm{K} 2$, samples $\mathrm{K} 2 / 3 \mathrm{~b}, \mathrm{~K} 2 / 4 \mathrm{~b}$, $\mathrm{K} 2 / 8 \mathrm{a}$, and $\mathrm{K} 2 /{ }_{12 \mathrm{~s}}$; section $\mathrm{K} 3$, samples $\mathrm{K} 3 \mathrm{~B} / 2 \mathrm{a}$, 


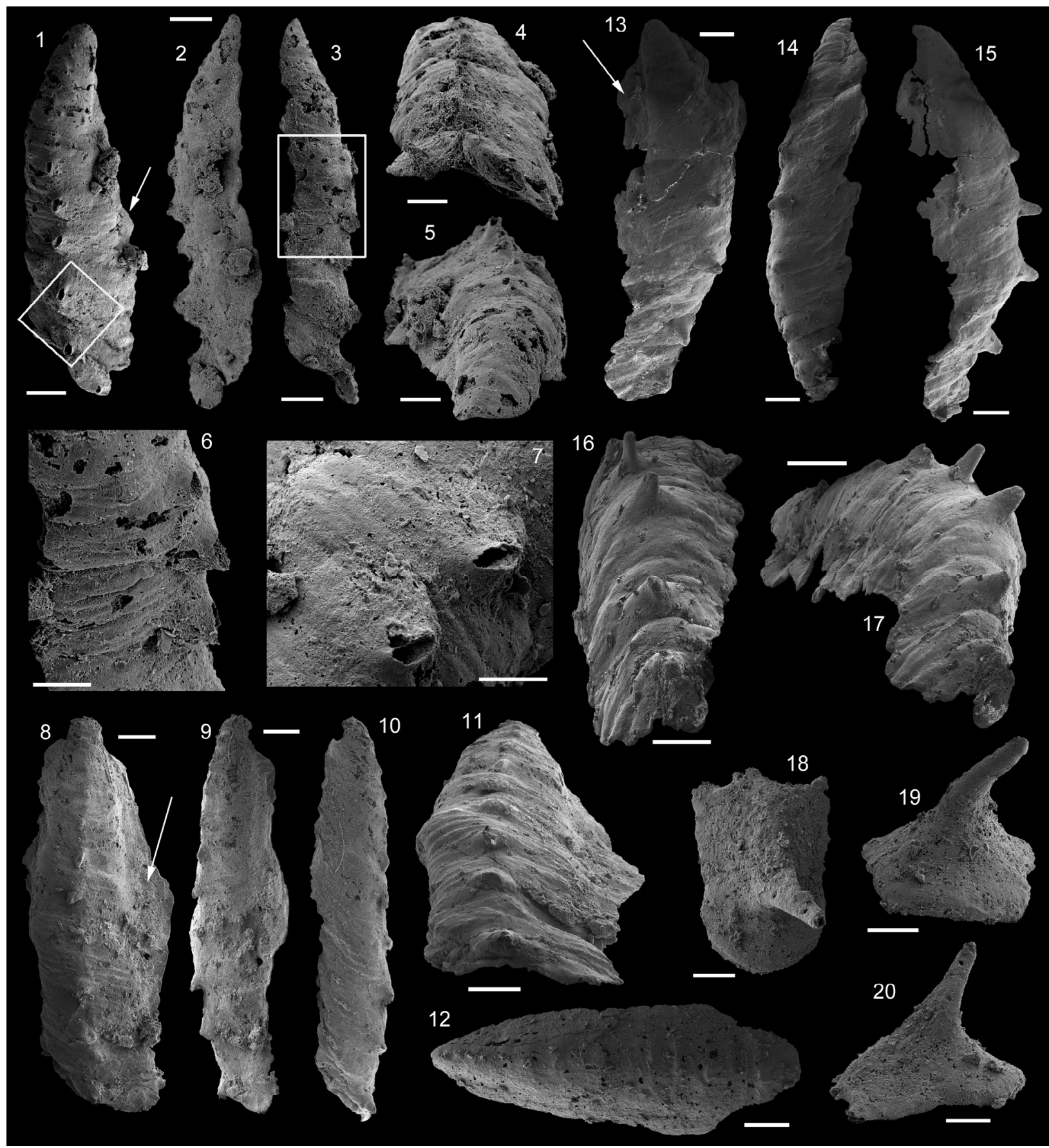

FIGURE 22. 1-17. Paracarinachites sinensis Qian and Jiang, 1982. 1-7. USTL1228/6: 1. Outer side view, square shows location of $7 ; 2,3$. Lateral views, square shows location of 6 , arrow shows location of $7 ; 4$. Abapical view; 5. Apical view; 6. Detail of oblique, slightly undulating transverse striations; 7. Detail of denticles. 8-11 USTL1225/3: 8. Outer side view, arrow shows lateral flange; 9, 10. Lateral views; 11. Abapical view. 12. Specimen USTL1211/15, outer side of internal mold. 13-17. USTL1225/1: 13. Outer side view, arrow shows lateral flange; 14, 15. Lateral views; 16. Abapical view;17. Lateral abapical view. 18-20. Paracarinachites sp. USTL1216/9: 18. Outer side view of one growth increment; 19, 20. Lateral views. Scale bars equal: 4-7, 18-20, $100 \mu \mathrm{m} ;$ 1-3, 8-17, $200 \mu \mathrm{m}$. 
$\mathrm{K} 3 \mathrm{~B} / 6, \mathrm{~K} 3 \mathrm{~T} / 2 \mathrm{c}, \mathrm{K} 3 \mathrm{~T} / 2 \mathrm{e}, \mathrm{K} 3 \mathrm{~T} / 3 \mathrm{a}, \mathrm{K} 3 \mathrm{~T} / 4 \mathrm{a}$; section $\mathrm{K} 4$, samples $\mathrm{K} 4 / 7$ and $\mathrm{K} 4 / 17$; section $\mathrm{K} 5$, samples $\mathrm{K} 5 \mathrm{~b} /$ 2, $\mathrm{K} 5 /_{32}, \mathrm{~K} 5 /_{35}, \mathrm{~K} 5 / 39$, and $\mathrm{K} 5 / 40$.

Description. The sclerites, well-preserved only as phosphatic external molds, are bilaterally symmetrical and nail-shaped (Figure 22.1, 22.8, 22.13). The narrower extremity of the sclerite is called apical end or apex. The observed maximum length is $3.5 \mathrm{~mm}$ and the maximum width is about $1 \mathrm{~mm}$. Sclerites are elongate and narrow (width/length ratio from $1 / 6$ to $1 / 3$ ). They are $0.6 \mathrm{~mm}$ in maximum height with a height/length ratio from $1 / 8$ to $2 / 7$ in flattest (Figure 22.8-11) to highest (Figure 22.17) specimens, respectively. In lateral view, most sclerites are crescent shaped with the inner side concave (Figure 22.2-3, 22.13--22.15), but are rarely flat (Figure 22.9-10). They are also highly concavo-convex,almost semi-circular in shape, in transverse section (Figure 22.4, 22.11, 22.15). The apical end is generally the most sagitally curved part of the sclerite while the abapical end is almost straight (Figure 22.2, 22.15). The apex has a sharp beak-like shape whereas the abapical end is bluntly rounded (Figure $22.1,22.8$ ). The outer side is differentiated from the smooth inner side by the presence of 5 to 10 blunt spiny projections, called denticles, in its medial part (Figure 22.15, 22.17). Denticles are aligned in a median row, forming a crest. The denticles, up to $0.2 \mathrm{~mm}$ in maximum length, are either perpendicular to the upper sclerite surface or bent abapically (Figure 22.15). They gently point toward random lateral, abapical directions (Figure 22.16). The distance between denticles increases toward the abapical end (Figure 22.15). Outer ornamentation consists of major and minor oblique, slightly undulating, transverse striations with a gentle chevron organisation faintly pointing toward the abapical end (Figure 22.3, 22.6). Major striations most probably delimit successive growth increments; each increment bears a denticle. When visible, minor striations, maybe also growth lines, are faint (Figure 22.7). The lateral flanks exhibit a delicate flange often absent (arrowed in Figure 22.1, 22.8, 22.13).

The internal, feather-shaped molds are very abundant in the residues. Imprints of the lateral flanges and limits of growth increments are visible (Figure 22.12) but internal molds are otherwise completely smooth.

Discussion. The present specimens are assigned to $P$. sinensis because they lack the two alternating rows of denticles of $P$. parabolicus Qian and Bengston, 1989. They differ from P. spinus (Yu, $1984 b)$ in the shorter and blunt denticles, the more clearly separated growth increments, and the blunty rounded apical end. External molds are scarce but provide the best morphological details, as most of the original structures of the shell are visible. Qian and Bengtson (1989) noticed that the lateral flange of Paracarinachites sinensis is only available on the Montagne Noire specimens from the Heraultia Limestone studied and illustrated by Kerber (1988). This character is also clearly distinguishable from other specimens studied herein. Qian and Bengtson (1989) explained the absence of flanges in Chinese material by the generally poor preservation in their samples and the relatively low number of specimens compared with hundreds of specimens studied by Kerber (1988). According to them, Kerber (1988) had more probability to get complete and well-preserved specimens. Protopterygotheca leshanensis Chen in Qian et al., 1979 is a trilobate sclerite composed of a central axis flanked by marginal flanges from the Maidiping Formation, Nemakit-Daldynian to Tommotian (Paragloborilus subglobosus-Purella squamulosa Zone to Watsonella crosbyi Zone) of Maidiping, Emei County, Sichuan province, China. The central axis is occassionally crossed by furrows and the median part of the central axis bears a series of reduced tubercules inclined abapically. Therefore, $P$. leshanensis is somehow similar to Paracarinachites sinensis. However, Conway Morris and Menge (1991) pointed out that the median row of tubercules is irregularly preserved in $P$. leshanensis, whereas the lateral flanges are always more or less expressed, although the tubercules are expected to be more robust than the flanges. Consequently, they assume that the absence of tubercules is not due to preservational biases, and they maintain the species $P$. leshanensis as valid. Denticles are not visible on internal molds of the sclerite but are preserved as hollow cones in the external phosphatic coating. Denticles are therefore massive structures of the shell.

The French material also shows one isolated growth increment of Paracarinachites sp. (specimen USTL1216/9; Figure 22.18-22.20), which most probably belongs to $P$. sinensis, even if it also shares the more quadrangular shape of $P$. spinus growth-increment. They can be distinguished from Cambroclavus sclerite by its concave base and absence of articulation surface.

Other occurrences. China: Zhongyicun Member of the Zhujiaqing Formation, Nemakit-Daldynian (Paragloborilus subglobosus-Purella squamulosa Zone) at Xiangfeng, Xundian County (Jiang, 1980b; Luo et al., 1980, 1982, 1984; Yu, 1987b; 


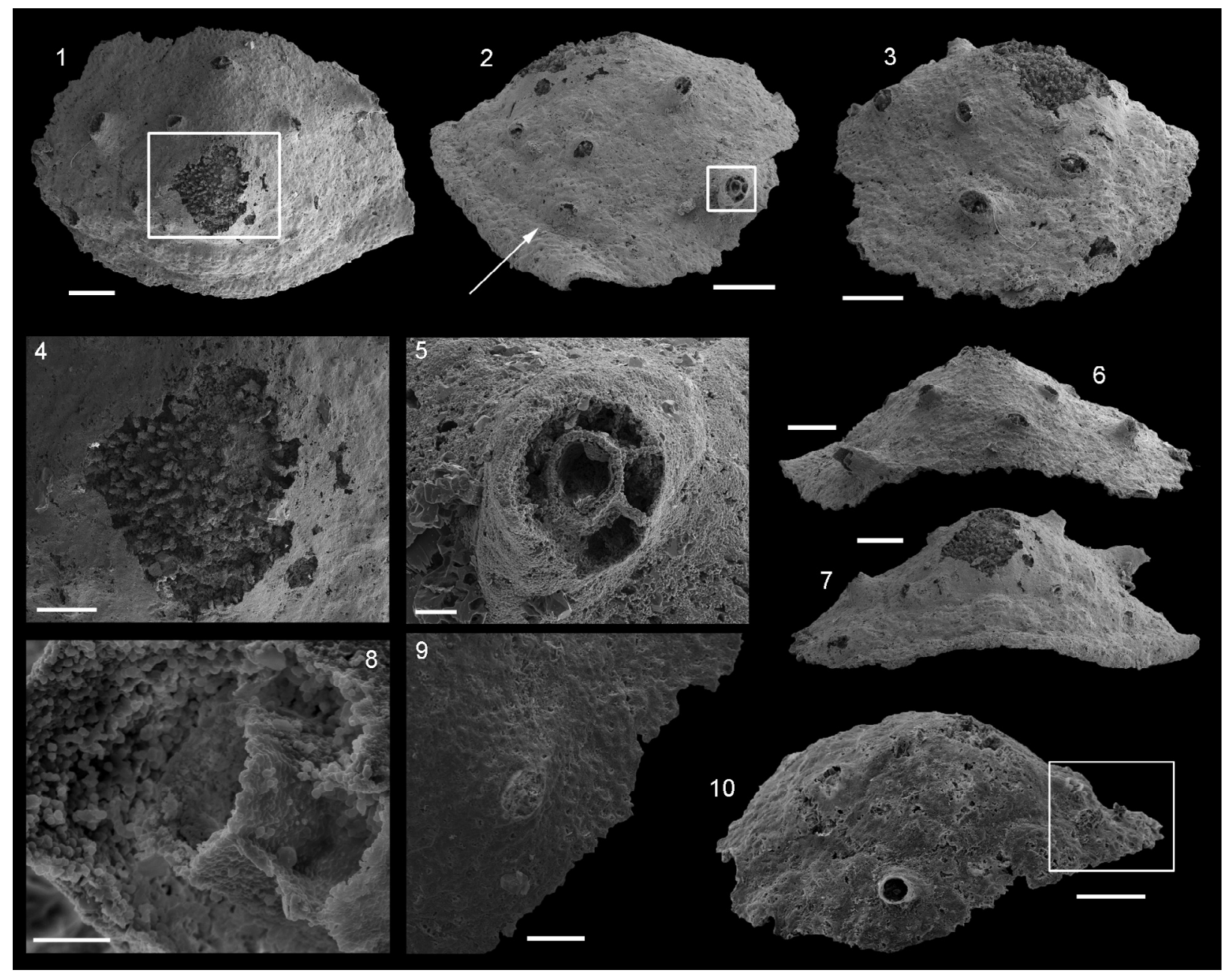

FIGURE 23. Aculopileus aculeatus Kerber, 1988. 1-8. USTL1220/8: 1. Upper view, square shows location of 4; 2. Lateral view, square shows location of 5 and 8 , arrow shows furrow parallel to fold associated with subapical apertural margin; 3. Lateral view; 4. Detail of densely spaced papillae of the internal mold; 5 . Detail of projecting hollow tube; 6; 6. Abapical view; 7. Apical view; 8. Detail of projecting hollow tube. 9-10. USTL1220/18: 9. Detail of irregular polygonal pattern of external coating; 10 . Lateral view with hollow tube visible; square shows location of 9 . Scale bars equal: $5,8,20 \mu \mathrm{m} ; 4,9,100 \mu \mathrm{m} ; 1-3,6,7,10,200 \mu \mathrm{m}$.

Qian, 1984; Qian and Bengtson, 1989; Yu, 1993; Qian and Zhu, 2001; Wen, 2001), at Shangssu, Jinning County (Yu, 1993), and at Baizai, Xundian County (Yu, 1987b; Yu, 1993, Yu, 2001), and Yulu, Huize County (Yu, 1987b; Yu, 1993; Yu, 2001) Yunnan Province; Zhongyicun and Dahai members of the Zhujiaqing Formation, Nemakit-Daldynian to Tommotian (Anabarites trisulcatus-Protoherzina anabarica; Paragloborilus subglobosus-Purella squamulosa and Watsonella crosbyi zones) at Meishucun, Jinning County, Yunnan Province, China (Yu, 1987b; Qian and Bengtson, 1989; Qian, 1989; Yu, 1993; Yu, 2001; Parkhaev and Demidenko, 2010); Dahai Member of the Zhujiaqing Formation, Tommotian (Watsonella crosbyi Zone) at Baideng, Anning County, Yunnan Province (Jiang, 1984).

\section{Genus ACULOPILEUS Kerber, 1988}

1988 Aculopileus Kerber, 1988, p. 184.

Type species. Aculopileus aculeatus Kerber, 1988, Tommotian (Watsonella crosbyi-Oelandiella korobkovi Interval Zone), Marcou Village, Hérault, France.

Diagnosis. See Kerber (1988).

Aculopileus aculeatus Kerber, 1988 Figure 23.1-10

1988 Aculopileus aculeatus Kerber, 1988, p. 184 , pl. 9, figs. 13-16.

Material. Two broken internal molds with external coating including USTL1220/8 and USTL1220/18.

Distribution. Section K2, samples K2/12s. 
Description. The conch is relatively high capshaped with a length of $1200 \mu \mathrm{m}$, a width of 1780 $\mu \mathrm{m}$ and a height of $1100 \mu \mathrm{m}$. The apex is blunt, slightly shifted toward one side and lies on the plan of symmetry (Figure 23.1, 23.6-7). The aperture is oval in outline with a slight lateral elongation (Figure 23.1). The subapical field (the surface under the apex) is slightly concave to straight in lateral view and presents a furrow parallel to a fold associated with the subapical apertural margin (arrowed in Figure 23.2). The dorsal field (the largest surface between the apex and the apertural margin) is slightly convex to straight in lateral view (Figure 23.2-3). The lateral fields are straight in lateral view (Figure 23.6-7). The internal mold exhibits densely spaced papillae perpendicular to the internal mold surface (Figure 23.4). Randomly distributed projecting hollow tubes are part of the external coating and point perpendicularly to the external coating surface (Figure 23.5-10). Their diameter is relatively large, up to $85 \mu \mathrm{m}$ and increases toward the apertural margin (Figure 23.2-3). They occassionally consist of an inner hollow tube encased in an outer one with papillae connecting both (Figure 23.5). Generally, a simple hollow tube is observed (Figure 23.3, 23.9-10). The external coating exhibits an irregular polygonal pattern (Figure 23.9).

Discussion. Aculopileus aculeatus has a very peculiar shell organisation. The presence of papillae between the internal mold and the external coating indicates that the calcareous shell was originally porous. The simple hollow tubes of the external coating may represent spines of the original shell. The occassionally imbricated hollow tubes making the projections may originally correspond to an internal spicule-like structure separated from a thick porous tube by organic tissues(?).

Comparison. The projections of Aculopileus aculeatus can be compared with the tubular projections of Archaetremaria polytremata Yu, 1979 and Granoconus trematus Yu, 1979. However, in both species, the tubular projections are aligned along the median crest of the dorsal field, which differs from the randomly distributed tubular projections of $A$. aculeatus. The projections can superficially be compared to the hollow spines of the siphonotretid brachiopods (especially the genera Siphonobolus Havlíček, 1982 and Siphonotretella Popov and Holmer, 1994). However, the larval and postlarval shells of siphonotretid brachiopods lack a pitted microornamentation, whereas the external coating of $A$. aculeatus exhibits an irregular polygonal pattern that could be compared to the dimpling micro- ornament of certain brachiopods. Moreover, the shell of $A$. aculeatus is interpreted herein as calcareous, whereas the shell of siphonotretid brachiopods is organophosphatic.

\section{Genus ALACONCHA Devaere, Clausen and Steiner, Gen. nov. \\ http://zoobank.org/C5C1A517-3AF2-4A3B-8E4A- 16F957355FB3}

Etymology. Latin Ala, wings and Concha, conch. Referring to the wing-like projections (auricles) of the subapical shelf of the conch.

Type species. Alaconcha rugosa, Devaere sp. nov., Tommotian (Watsonella crosbyi-Oelandiella korobkovi Interval Zone), Marcou Village, Hérault, France.

Diagnosis. Low cap-shaped bilaterally symmetrical conch. Conch oval in dorsal view, with slightly ventrally curved apertural margin. Apex in the plane of symmetry, displaced toward the posterior side and overhanging the apertural margin. Subapical field concave, with a subapical shelf separated by a sinus into two auricles. Shell plicated.

Comparisons. The newly erected genus shares with tail valves of Ocruranus Liu, 1979 the approximately rounded shape (generally wider than long) and the presence of both arched (with an emargination flanked by projections) and opposite rounded margins. Moreover, they both exhibit a prominent, lowered subapical shelf. However, the plicated structure of the shell of Alaconcha Devaere, gen. nov. has never been described in Ocruranus.

\section{Alaconcha rugosa Devaere, Clausen and Steiner, sp. nov. \\ Figure 24.1-11 \\ http://zoobank.org/E3A1D395-A7AC-4224-A096- 8ED51D34B5C4}

Etymology. Latin rugosa, for the presence of comarginal folds.

Holotype. Specimen USTL1247/3, Figure 24.1-3, 24.5-6, 24.9; phosphatic internal moulds, from Marcou village, Heraultia Limestone, sample K3T/3a.

Material. Four phosphatic internal molds including USTL1238/9, USTL1225/11, and USTL1247/3.

Distribution. Section $\mathrm{K} 3$, samples $\mathrm{K} 3 \mathrm{~B} / 6, \mathrm{~K} 3 \mathrm{~T} / 2 \mathrm{~d}$, $\mathrm{K} 3 \mathrm{~T} / 2 \mathrm{e}$, and $\mathrm{K} 3 \mathrm{~T} / 3 \mathrm{a}$.

Diagnosis. As for the genus.

Description. The internal mold of the conch is low cap-shaped, up to $2100 \mu \mathrm{m}$ long, $2650 \mu \mathrm{m}$ wide, and $810 \mu \mathrm{m}$ high (height/length ratio of $3 / 8$ ). The aperture is oval in outline in upper view, with the compression directed along the apical/abapical direction (length/width ratio of $4 / 5$; Figure 24.1, $24.4,24.7)$. The conch is therefore strongly elon- 


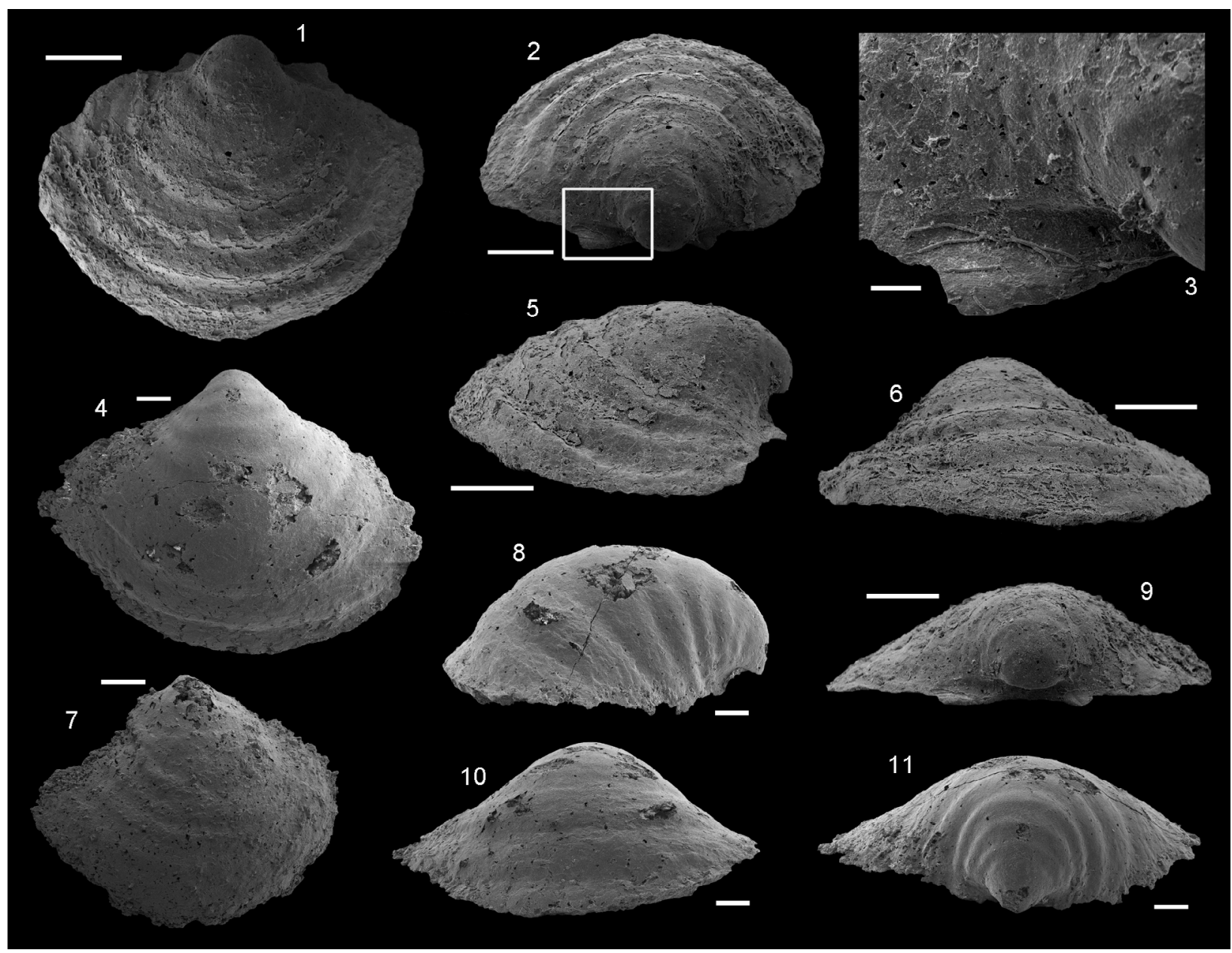

FIGURE 24. Alaconcha rugosa Devaere, sp. nov. 1-3, 5, 6, 9. USTL1247/3: 1. Upper view; 2. Apical view, square shows location of 3; 3. Detail of subapical projections; 5. Lateral view; 6. Abapical view; 9. Apical view. 4, 8, $10,11$. USTL1225/11: 4. Upper view; 8. Lateral view; 10. Abapical view; 11. Apical view. 7. USTL1238/9, upper view. Scale bars equal: 3, $100 \mu \mathrm{m} ; 4,8,10,11,200 \mu \mathrm{m} ; 7,300 \mu \mathrm{m} ; 1,2,5,6,9,500 \mu \mathrm{m}$.

gate laterally (Figure 24.1, 24.4, 24.7). The aperture is slightly curved in lateral view (Figure 24.5; flat in Figure 24.8 due to breakage). The blunt (Figure 24.2, 24.5, 24.9) to pointed (Figure 24.8, 24.11) apex lies in the plane of symmetry (Figure 24.1, $24.7,24.11)$. It is curved downward and overhangs the subapical apertural margin (Figure 24.1, 24.2, $24.4,24.7,24.9,24.11)$. The dorsal field (the largest surface between the apex and the apertural margin) is strongly convex in lateral view although it tends to become straight toward the apertural margin (Figure 24.5, 24.8). The subapical field (the surface under the apex) is short and deeply concave (Figure 24.5, 24.8) and becomes sub-horizontal near the posterior margin, delimiting a small subapical shelf (Figure 24.2-3, 24.5, 24.9). It is divided into two symmetrical auricles diverging from the apex (Figure 24.2-3, 24.9). Between the two auricles, a shallow sinus in the apertural mar- gin is observed (Figure 24.9). The lateral fields are large and straight (to slightly concave) in anterior/ posterior view (Figure 24.6, 24.9-11). The surface of the internal mold bears a few (from 6 to 7 ) high amplitude comarginal folds spaced by at most 300 $\mu \mathrm{m}$ (Figure 24.1, 24. 4-7, 24.10-11).

Comparisons. Alaconcha rugosa Devaere, sp. nov. can be roughly compared to Emarginoconus mirus Yu, 1979. E. mirus consists of a cap-shaped, low conical conch, with an apex curved and shifted to the posterior margin. However, the apex does not strongly overhang the subapical margin. Moreover, in dorsal view, the conch is circular in outline whereas the present new species is strongly laterally elongate. Internal molds of $E$. mirus are unknown but observations on the internal surface of the conch indicate that no ribs are internally expressed, contrary to the ones found on the present internal molds. A. rugosa is similar to anterior 
and posterior shells of Halkieria evangelista Conway Morris and Peel, 1995. Both type of shells have comarginal growth lines including strongly defined increments separated by finer lines. However, the growth lines are much finer than the high amplitude comarginal folds of $A$. rugosa. They also exhibit radial ornamentation consisting of very narrow ridges that radiate from the apex across the entire shell and which are absent in $A$. rugosa. The anterior shells of $H$. evangelista are slightly wider than long and exhibit auricles-like extensions on either side roughly similar to those of $A$. rugosa. The apex is marginal and projecting over the subapical margin. The posterior shells of $H$. evangelista are oval, slightly longer than wider. However, posterior shells of $H$. Evangelista are much lower than $A$. rugosa although they are more cap-like in the early stages of ontogeny and they are slightly longer than larger (Conway Morris and Peel, 1995). A. rugosa is comparable to one indetermined brachiopod described in the Heraultia Limestone (Figures 18.1-5). They both share a similar triangular to oval shape in dorsal view and the presence of few high amplitude comarginal folds. However, the possible brachiopods have a larger and poorly defined apex, the comarginal folds are more triangular in profile, and they lack the typical subapical auricles of $A$. rugosa.

Kingdom, phylum, class, order, and family uncertain

Genus AETHOLICOPALLA Conway Morris, 1990

1988 Archaeooides Qian; Kerber, p. 189.

1990 Aetholicopalla Conway Morris in Bengston et al., 1990, p. 338.

1992 Archaeooides; Elicki and Schneider.

1998 Aetholicopalla; Elicki, p. 58.

Type species. Aetholicopalla adnata Conway Morris, 1990, Atdabanian (Abadiella huoi to Parararia tatei trilobite Zone), Curramulka, Yorke Peninsula, Stansbury Basin, South Australia.

Diagnosis. See Conway Morris in Bengtson et al. (1990).

Aetholicopalla adnata Conway Morris, 1990

Figure 25.1-23

1988 Archaeooides granulatus Qian; Kerber, p. 189, pl. 11, figs. 13-20.

1990 Aetholicopalla adnata Conway Morris in Bengtson et al., 1990, p. 338, figs. 213216.

1990 Aetholicopalla adnata; Elicki, p. 58, pl. I, figs. $6-9$, pl. II.
1992 Archaeooides granulatus; Elicki and Schneider, pl. 16, figs. 8, 9.

2009 Aetholicopalla adnata; Topper et al., p. 219 , figs. $6 S-U$.

Material. Thirty complete to slightly broken phosphatic specimens including USTL1211/6, USTL1236/1, USTL1243/1, USTL1258/11, USTL1258/13, and USTL1262/13.

Distribution. Section $\mathrm{K} 2$, samples $\mathrm{K} 2 /{ }_{6}$ and $\mathrm{K} 2 /{ }_{16}$; section $\mathrm{K} 3$, samples $\mathrm{K} 3 \mathrm{~B} / 4, \mathrm{~K} 3 \mathrm{~B} / 6, \mathrm{~K} 3 \mathrm{~T} / 2 \mathrm{c}, \mathrm{K} 3 \mathrm{~T} / 2 \mathrm{e}$, $\mathrm{K} 3 \mathrm{~T} / 3 \mathrm{a}, \mathrm{K} 3 \mathrm{~T} / 4 \mathrm{a}$; section $\mathrm{K} 4$, samples $\mathrm{K} 4 / 4 \mathrm{a}$ and $\mathrm{K} 4 /$ 7; section $\mathrm{K} 5$, samples $\mathrm{K} 5 \mathrm{~b} / 3, \mathrm{~K} 5 \mathrm{~b} / 4, \mathrm{~K} 5 /{ }_{12}, \mathrm{~K} 5 / 17$, $\mathrm{K} 5 / 19$, and $\mathrm{K} 5 / 25$.

Description. The test is spherical to ellipsoid in shape (average degree of eccentricity of 7 to $8 / 10$ ) rarely highly flattened with a maximum degree of eccentricity of $1 / 2$ (Figure 25.17, 25.19-21). Most of the specimens exhibit a differentiated attachment area on the outer surface (arrowed in Figure $25.2,25.17,25.21$ ), but this structure is not systematically present (Figure 25.3-4). Specimens are either isolated or still attached to the incrusted substrate, which can be fossil remains or lithoclasts (Figure 25.14-15). The attachment surface can be completely flat, convex, or concave (most probably due to morphological accommodation to the encrusted substrate). The test is bilayered (Figure $25.5,25.9,25.13$ ) enclosing a central cavity which is occassionally infilled with diagenetic phosphate debris (Figure 25.5). The two peripheral layers are separated by short connecting structures with irregular arrangement but gross radial orientation (Figure 25.10). These structures are either hollow tubes (Figure 25.3-4) or massive pillars (Figure $25.9,25.13)$. Hollow tubes are partly infilled by phosphate, their central canal is not present throughout the entire length and connection of exterior with internal cavity is interrupted. Nearly all the specimens lack the outer layer and the pillars or tubes, projecting from the inner layer, give a spinose or rugose appearance to the sphere/ ellipse (Figure 25.1-4, 25.14-23). Possible vermiform tubules are irregularly arranged through the remaining central cavity (Figure 25.12). The relationship of central tubules and peripheral pillars is hardly assessed because of direct observation is not possible and inner tubules might correspond to phosphatised microbial filaments. The outer layer is partly preserved (small area) in a single specimen (Figure 25.7-8, 25.11). The outer surface of the outer layer is smooth and lacks remarkable features except for (taphonomically induced?) open- 


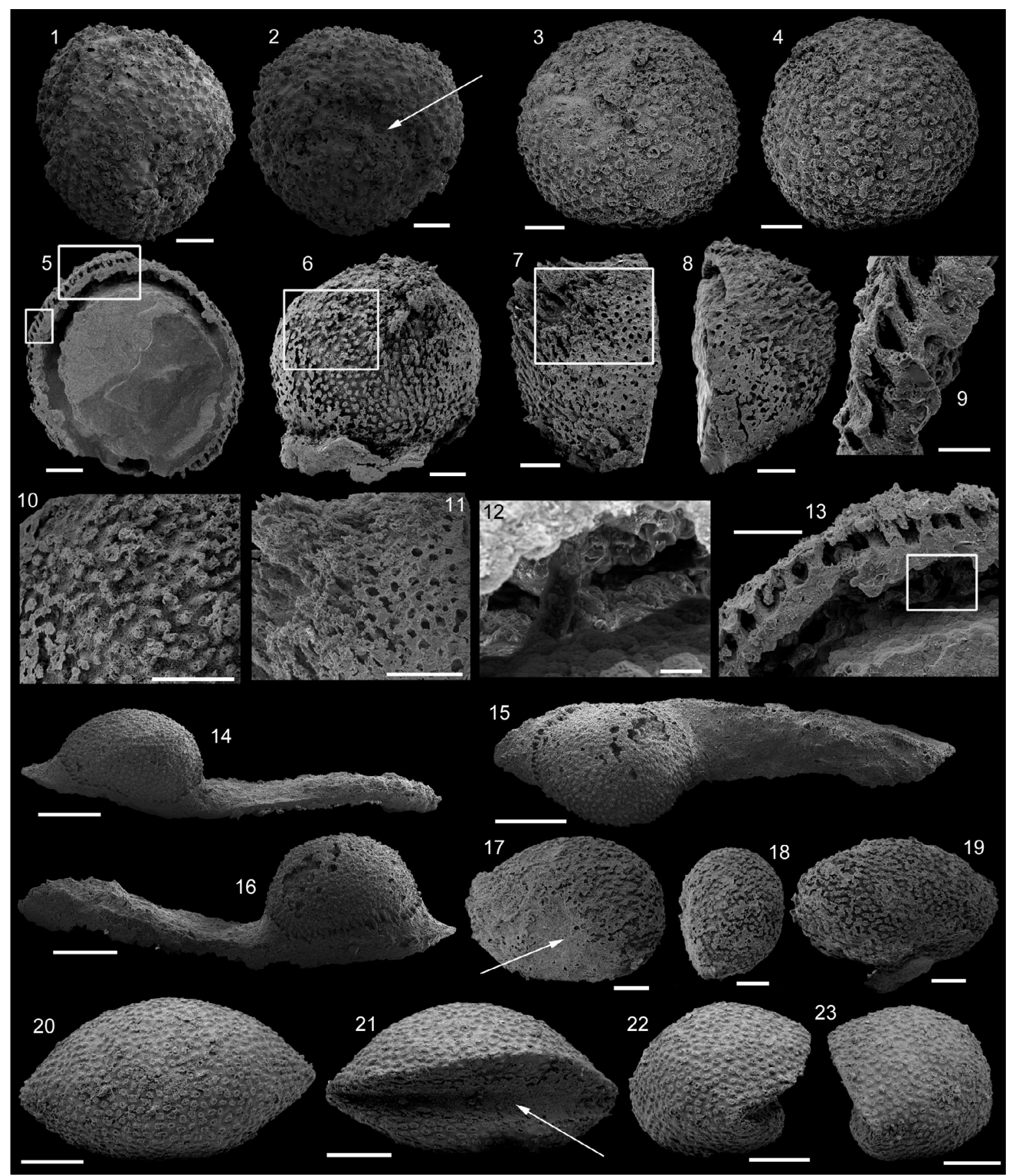

FIGURE 25. Aetholicopalla adnata Conway Morris, 1990. 1-2. USTL1211/6: 1. External view; 2. Arrow shows attachment area. 3-4. USTL1262/13. 5-13. USTL1258/13: 5. Cross section showing internal cavity, lower square shows location of 9; upper square shows location of $13 ; 6$. External view, square shows location of $10 ; 7,8$. External view, internal and external phosphatic layers, square shows location of 11; 9 . Detail of the two phosphatic layers with interconnecting pillars; 10. Detail of external surface of inner phosphatic layer; 11. Detail of external phosphatic layer; 12. Detail of possible bacterial filament; 13 . Partly filled internal cavity and empty space next to phosphatic layers, square shows location of 12. 14-16. USTL1236/1: 14, 15. Lateral views of specimen attached to a clast; 16. Upper view. 17-19. USTL1258/11: 17. Arrow shows attachment area; 18. Lateral view; 19. Side opposite to attachment. 20-23. USTL1243/1: 20. Side opposite to attachment; 21. Attachment side, arrow shows deformation due to attachment; 22, 23. Lateral views. Scale bars equal: 12, $20 \mu \mathrm{m} ; 9,50 \mu \mathrm{m} ; 13,100 \mu \mathrm{m}, 1-8,10,11,17-19,200 \mu \mathrm{m}, 14-16,20-23,500$ $\mu \mathrm{m}$. 
ings between insertions of the underlying massive pillars (Figure 25.11).

Discussion. Kerber (1988) assigned the described form to Archaeoides granulatus Qian, 1977. However, it clearly differs from $A$. granulatus in the organisation of the layer structure (two layers connected by hollow tubes/massive pillars) and by its encrusting life-habit, two characters absent in $A$. granulatus but diagnostic of Aetholicopalla adnata (Conway Morris in Bengtson et al., 1990).

The phosphatic bilayered structure of Aetholicopalla may be related to the phosphatic replacement of two originally non-phosphatic layers, subsequently replaced, during early diagenesis, by phosphate. It could also correspond to external and internal phosphatic coatings of a unilayered shell possibly of carbonate nature. The study of thin sections of samples rich in $A$. adnata reveals that calcareous shells (hyoliths, molluscs) are generally preserved. A thin external phosphatic coating occurs on the preserved calcareous shell of some specimens and a complete phosphatic internal mold or a thin phosphatic coating of the internal cavity is also present. Such preservation has already been observed by Clausen and Álvaro (2007) in samples from the same outcrops. The fossils were extracted by acetic acid, the preserved calcareous shell has therefore been dissolved, and only the internal and external molds are available. This observation would favor the hypothesis of an original one-layered hollow calcareous shell diagenetically coated by phosphate (Conway-Morris in Bengtson et al., 1990). However, one broken specimen shows a phosphatic ball (microbial coccoids?) partly infilling the inner cavity and separated from the inner phosphatic layer by a rather constant void infilled with putative irregular tubules/microbial filaments (Figure 25.5). That questions the above-mentioned interpretation and would argue for a double calcareous layer externally coated and internally filled by phosphate, an outer layer perforated by rather straight canals, and an inner layer by irregular canals. Nevertheless, such phosphatic ball partly infilling the inner cavity, separated from inner phosphatic layer by a void has not been observed in any other specimen. In the other specimens, phosphate cements are completely occluding the inner cavity. The inner phosphatic ball may be the result of late diagenetic withdrawal of phosphates or early diagenetic calcite cement then dissolved in acetic acid. This observation is in accordance with the interpretation of Aetholicopalla as a unilayered carbonate shell. An apparently folded specimen (Figures 25.20,
25.23) argues for an heterogeneously, sometimes weakly, mineralized skeleton among specimens although the deformation may just result from growth accommodating the attachment substrate.

The connecting structures observed between the two reported layers are described either as hollow tubes or as massive pillars. Both most probably correspond to different preservation-types of the same original structure: a canal piercing a calcareous shell. In the case of the hollow tubes, the canal has not been totally filled but coated with phosphate. In the case of massive pillars, the canal was completely filled by phosphate. The described specimens do not shed light on the function of such canals. According to the interpretation of the two phosphatic layers as diagenetic coatings of a calcareous shell, these canals would represent communications between the internal cavity and the external environment. Conway Morris (in Bengtson et al., 1990) described some outer phosphatic layers as imperforate. Our material confirms ConwayMorris' (in Bengtson et al., 1990) interpretation as this certainly occurs when the external phosphatic coating is highly thorough and the canal might have been totally filled with phosphate. In agreement with the hypothesis of a bilayered calcareous shell, suggested by infilled specimens (Figure 25.9, 25.13), the communication to the exterior would occur through two tubule networks perforating the two concentric layers. This interpretation would contrast with Conway-Morris' (in Bengtson et al., 1990) observation of tubules mingled with inner phosphatic infill of the sphere, a character not observed herein (taphonomic artefact?). Narrow, reticulate ridges organised into a polygonal pattern are not seen on the outer surface of the inner phosphatic layer in contrast with the Australian specimens described by Conway Morris (in Bengtson et al., 1990).

Other occurrences. Stansbury Basin, South Australia: from Parara Limestone Member to Kooliwurtie Limestone Member, Atdabanian (Abadiella huoi trilobite Zone), Arrowie (Bengtson et al., 1990; Gravestock et al., 2001); Stansbury Limestone, Toyonian (Pelagiella madianensis Zone), Port Julia, Yorke Peninsula (Gravestock et al., 2001); Parara Limestone Member, Kulpara Formation, Atdabanian (Abadiella huoi Zone), Horse Gully and Ardrossan, Yorke Peninsula (Bengtson et al., 1990; Gravestock et al., 2001); Ajax Limestone, Atdabanian (Abadiella huoi and Pararaia tatei Zone), Mount Scott Range (Bengtson et al., 1990; Gravestock et al., 2001) and Mernmerna Formation, Atdabanian to Botoman (Abadiella huoi to Pararaia 


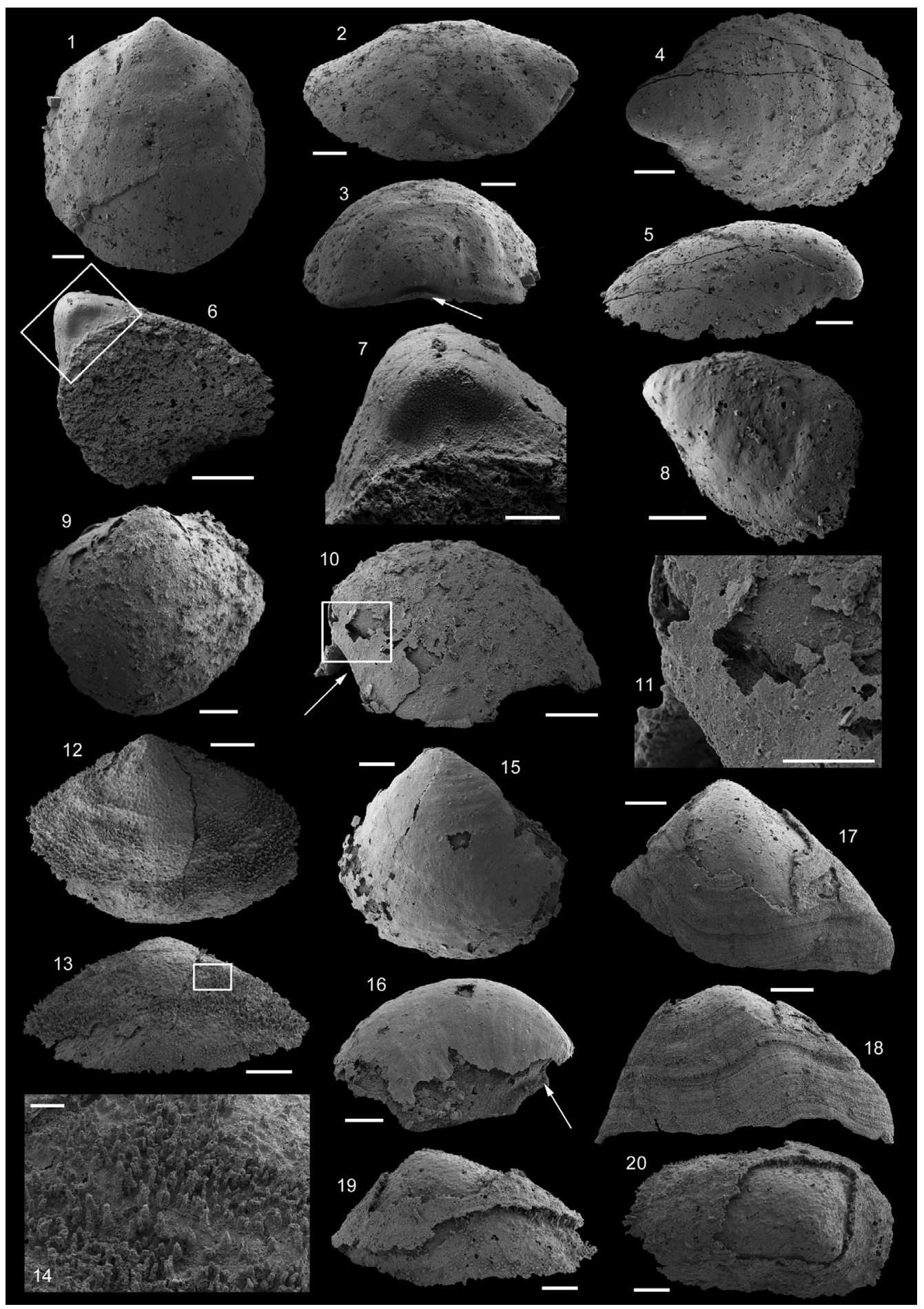

FIGURE 26. 1-3. USTL1209/3: 1. Dorsal view; 2. Lateral view; 3. Apical view, arrow shows slightly developed subapical shelf. 4-5. USTL1109/4: 4. Dorsal view; 5. Lateral view. 6-8. USTL1260/17: 6. Apertural view, square shows location of 7; 7. Detail of subapical field with polygonal imprints; 8. Dorsal view. 9-11. USTL1259/12: 9. Dorsal view; 10. Lateral-subapical view, square shows location of 11; 11. Detail of subapical area (internal mold and external coating preserved). 12-14. USTL1261/5: 12. Dorsal view; 13. Abapical view, square shows location of 14; 14. Detail of densely spaced papillae of the internal mold. 15-16. USTL1220/17: 15. Dorsal view; 16. Lateral view, arrow shows folded upwards subapical margin. 17-18. USTL1220/22: 17. Dorsal view; 18. Abapical view, sinusoidally striated external coating. 19-20. USTL1213/16: 19. Abapical view; 20. Dorsal view. Scale bars equal: 14, $60 \mu \mathrm{m} ; 7,11,15,16$, $100 \mu \mathrm{m} ; 1-5,9,10,17-20,200 \mu \mathrm{m} ; 6,8,12,13,300 \mu \mathrm{m}$. 
bunyerooensis Zone), Flinders Ranges (Topper et al., 2009).

Germany: Lower Ludwigsdorf Member, Charlottenhof Formation, Botoman, Görlitz Syncline (Elicki, 1998).

Antarctica: Allochthonous boulders, late Atdabanian-early Botomian (Pararaia tatei trilobite Zone), King George Island (Wrona, 2004).

Indeterminated cap-shaped microfossils

Figures 26.1-20, 27.1-18 and 28.1-4

Indeterminate cap-shaped microfossils preserved as phosphatic internal molds, occasionally bearing phosphatic external coatings, are very common in the samples. They can be divided into two major groups: low cap-shaped and high capshaped forms.

Among the low cap-shaped microfossils, numerous forms exhibit a marginal apex overhanging the apertural margin (Figure 26.1-18). The apex is occasionally sharp and the subapical field is steeply concave with the subapical apertural margin folded toward the apex (arrowed in Figure 26.3). Those forms are similar to the specimen PIN 4552/1514 of Eohalobia diandongensis Jiang in Luo et al., 1982 described in Parkhaev and Demidenko (2010) although its apex is more blunty and less projected over the apertural margin. However, the specimens of $E$. diandongensis published by Parkhaev and Demidenko (2010) do not correspond to the diagnosis of the genus Eohalobia. Here, they are not considered as even a morphological variation of $E$. diandongensis. The apex of other low cap-shaped internal molds is occassionally rounded and blunt, and the outer surface of the internal mold exhibits stout comarginal ribs (Figure 26.4-5). These forms were previously identified by Kerber (1988) as Bemella? sp. but they are much more depressed than Bemella Missarzhevsky in Rozanov et al., 1969 and not laterally compressed. They are somehow similar to Alaconcha rugosa Devaere, sp. nov. (Figure 24.1--1) due to the presence of comarginal high amplitude ribs and a rounded apex overhanging the apertural margin. However, they lack the lateral elongation typical of A. Rugosa, and the preservation is not accurate to determine if the subapical emargination was once present. They can be roughly compared to Securiconus Jiang, 1980 which is, however, much higher, with a concave subapical field better defined. Polygonal structures interpreted as replica of a prismatic shell layer can be observed on the subapical field of some specimens, but the latters exhibit a sharper apex (Figure 26.6-7). Moderately low cap-shaped forms with a marginal apex are also observed (Figure 26.9). The subapical margin is highly arched: it forms a sinus under the apex (arrowed in Figure 26.10). The subapical field is steeply concave with the subapical apertural margin folded upward although the presence of a smooth external phosphatic coating makes difficult those observations (Figure 26.11). The marginal apex is occassionally slightly protruding (as in Figure 26.12-18). Among those morphotypes, some specimens, triangular in outline, display granules on the outer surface of the internal molds (corresponding to the phosphatic infilling of shell pores; Figure 26.12-14). The external coating is occasionally preserved on other low-cap shaped microfossils with a slightly protruding marginal apex (Figure 26.15-16). Comarginal striations are present on the external coating but granules are not observed on the internal mold surface (Figure 26.15-16). The apertural margin in the subapical area is folded upward (arrowed in Figure 26.16). Sinusoidal striations on the external coating of similar triangular low cap-shaped morphotypes are occassionally encountered (Figure 26.17-18). Low cap-shaped internal molds with a central to subcentral apex are abundant. Granules may be present on the external surface of the internal mold, associated with a rough but non-striated external coating (Figure 26.19-20). Low cap-shaped forms with a slightly shifted apex and deep and sharp slits on the lateral fields are rarely found in the material (Figure 27.1-3). Their general shape varies between relatively high forms (Figure 27.1-2) to very low (Figure 27.3). The outer surface of the internal molds exposes, in the area of the slits, a polygonal texture corresponding to imprints of a prismatic shell layer (arrowed in Figure 27.2). This structure is similar to the structure observed on the lateral fields of internal molds of Eosoconus primarius Yu, 1979. However, the furrows are shallower and wider in E. primarius, and the conch is more rounded and higher than in the French specimens. Some morphotypes can be relatively high compared to other low cap-shaped forms (Figure 27.4-5). The apex is central, small and sharp and is accompanied by an external coating displaying comarginal striations which follow an apertural sinus, when present (Figure 27.4-5). Forms with non-sinuous comarginal striations on the external coating, but with a wide and rounded subcentral apex and granules on the internal mold, are also present (Figure 27.6-7).

Very low cap-shaped internal molds associated with external coating are common in the residues (Figure 27.8-10). Phosphatic tubules piercing 


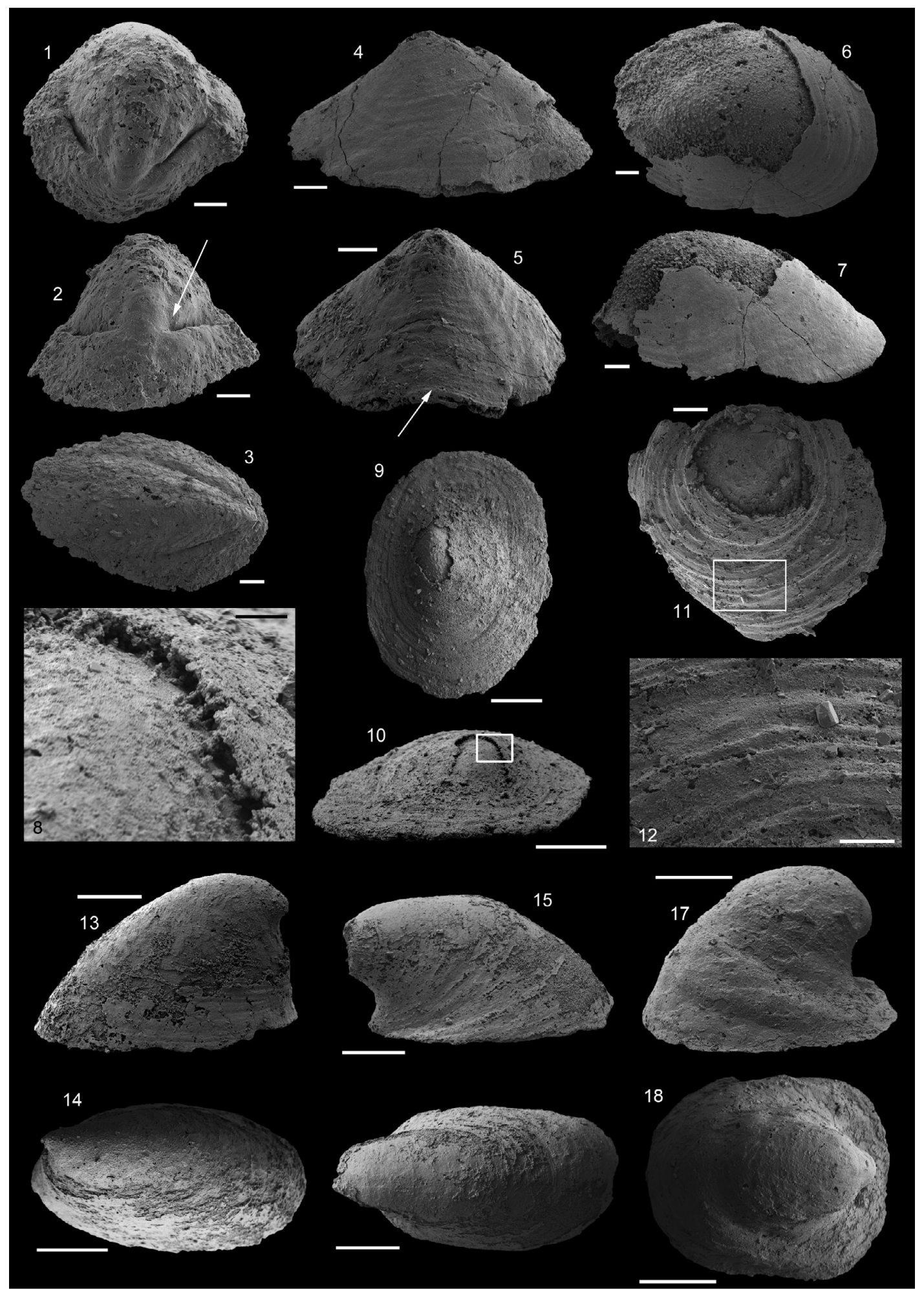

FIGURE 27. 1-2. USTL1235/13 L15_048-049: 1. Dorsal view; 2. Abapical view, arrow shows slit. 3. USTL1238/5, dorsal view. 4-5. USTL1223/13: 4. Lateral view; 5. Apical view, arrow shows sinus in apertural margin. 6-7. USTL1220/14: 6. Dorsal view; 7. Lateral view. 8-10. USTL1240/10: 8. Detail of internal mold an external coating; 9 . Upper view; 10. Lateral view, square shows location of 8. 11-12. USTL1217/22: 11. Dorsal view, square shows location of $12 ; 12$. Detail of external coating comarginal ribs. 13-14. USTL1243/4: 13. Lateral view; 14. Dorsal view. 15-16. USTL1241/6: 15. Lateral view; 16. Dorsal view. 17-18. USTL1241/5: 17. Lateral view; 18. Dorsal view. Scale bars equal: $8,12,50$ $\mu \mathrm{m}$; 4-7, 11, $100 \mu \mathrm{m} ; 1-3,200 \mu \mathrm{m} ;$ 9, 10, 13-18, $500 \mu \mathrm{m}$. 


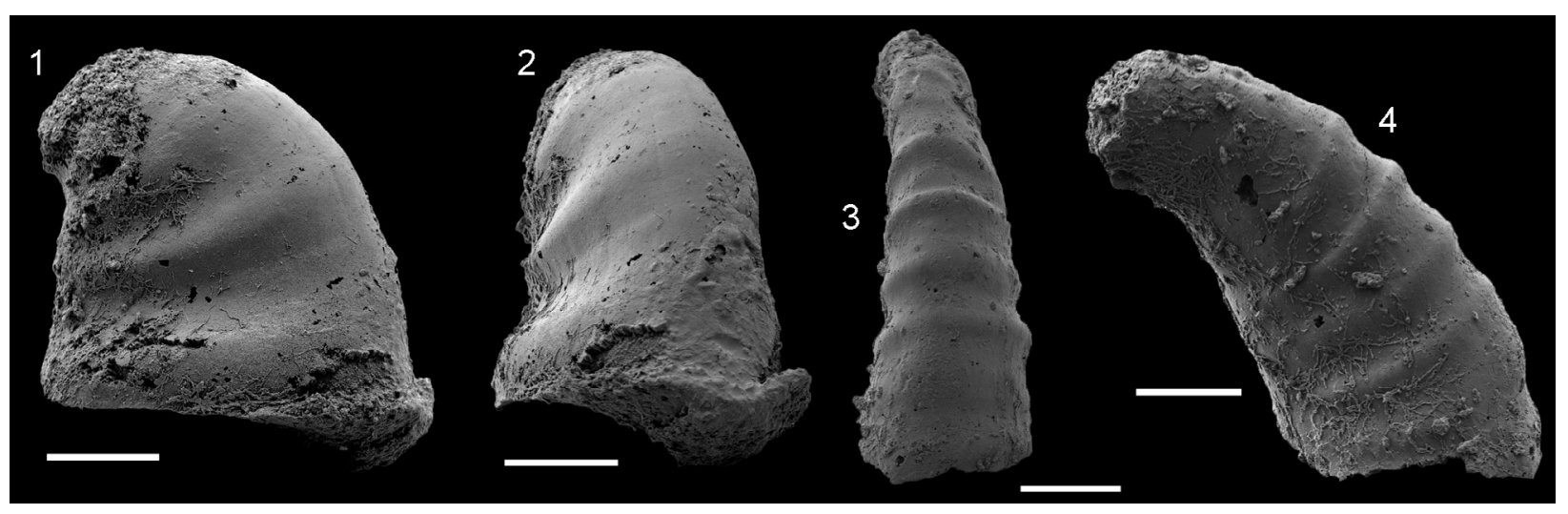

FIGURE 28. 1-2. USTL1243/6, Scale bar equals $500 \mu \mathrm{m}$. 1. Lateral view; 2. Abapical view. 3-4. USTL1242/3, scale bar: $300 \mu \mathrm{m}$. 3. Abapical view; 4. lateral view.

the shell, from the internal mold to the external coating, attesting the original presence of pores (Figure 27.8). The apex is subcentral and surrounded by a series of prominent comarginal striations (Figure 27.9-10). Kerber (1988) considered those forms to correspond to opercula of Turcutheca sp. indet. However, the opercula of Turcutheca Missarzhevsky in Rozanov et al., 1969 possess prominent cardinal processes and a differentiated articulation structure (offset marginal zone) that are absent from the Heraultia Limestone specimens (Rozanov et al., 1969). Kerber (1988) also noticed the similarity between the present specimens and Aegides places Jiang in Luo et al., 1982 (then emphasised with Aegitellus placus). However, A. placus is characterised by the presence of symmetrical muscle scars on the inner surface of the shell, which are absent on the internal molds from the Montagne Noire. Some similarities with Asiapatella Parkhaev and Zhegallo in Parkhaev and Demidenko, 2010 can be detected, although the wide and shallow sinus typical of this genus is absent from the apertural margin. Therefore, they are not interpreted as opercula but rather as very low cap-shaped molluscs. Forms with even more prominent comarginal ribs in the external coating are present (Figure 27.12), without any tubules associated with the internal molds and with a more shifted apex (Figure 27.11). Finally, high cap-shaped forms are also common in the residues. They can also be preserved as phosphatic internal molds associated with phosphatic external coatings (Figure 27.13-16). The phosphatic external coating may display fine striations (Figure $27.13,27.15)$. In some cases, the sharp apex is shifted toward the apertural margin, slightly curved downward but does not overhang the margin (Figure 27.13-14). Moreover, the striations are strictly comarginal (Figure 27.13). In other cases, the rounded apex is strongly shifted toward the apertural margin, which it overhangs (Figure 27.15-16). The striations visible on the external coating are curved and directed toward the subapical margin (Figure 27.15). Both morphotypes are oval in outline (Figure 27.14-16), but other morphotypes are more rectangular in outline (Figure 27.18). They also display an almost flat subapical shelf (Figure 27.17). Higher internal molds may have several, large, rounded lateral ribs that do not cross the dorsum (Figure 28.1-2). The highest forms consist of curved cones with several prominent comarginal ribs that cross the dorsum (Figure 28.3-4).

\section{AGE AND CORRELATION OF THE HERAULTIA LIMESTONE}

Although there are some faunal differences between the sampled logs (Figures 29-33), all contain elements suggestive of a late Nemakit-Daldynian and Tommotian age. Taxa characteristic of the late Nemakit-Daldynian and Tommotian from other early-Cambrian subtropical carbonate platforms, include: Halkieria operculus, Oelandiella korobkovi, Ocruranus cf. subpentaedrus, Paracarinachites sinensis, Pseudorthotheca acuticincta, Siphogonuchites triangularis, Watsonella crosbyi, and Xianfengella prima (an assemblage present in all the sections of the Avène-Mendic parauthochton), and Bemella cf. simplex, Dorispira lauta, Lomasulcachites macrus, Paragloborilus subglobosus, Protoconus orolgainicus, and Purella gracilis (Figure 34).

Halkieria sacciformis and Pseudorthotheca rotundicincta are known from the Nemakit-Daldynian-Atdabanian (Rhombocorniculum cancellatum Zone) of the Zhanaary and Taldybulak members (Beshtash Formation) of Beshtash, Talass Alatau, 

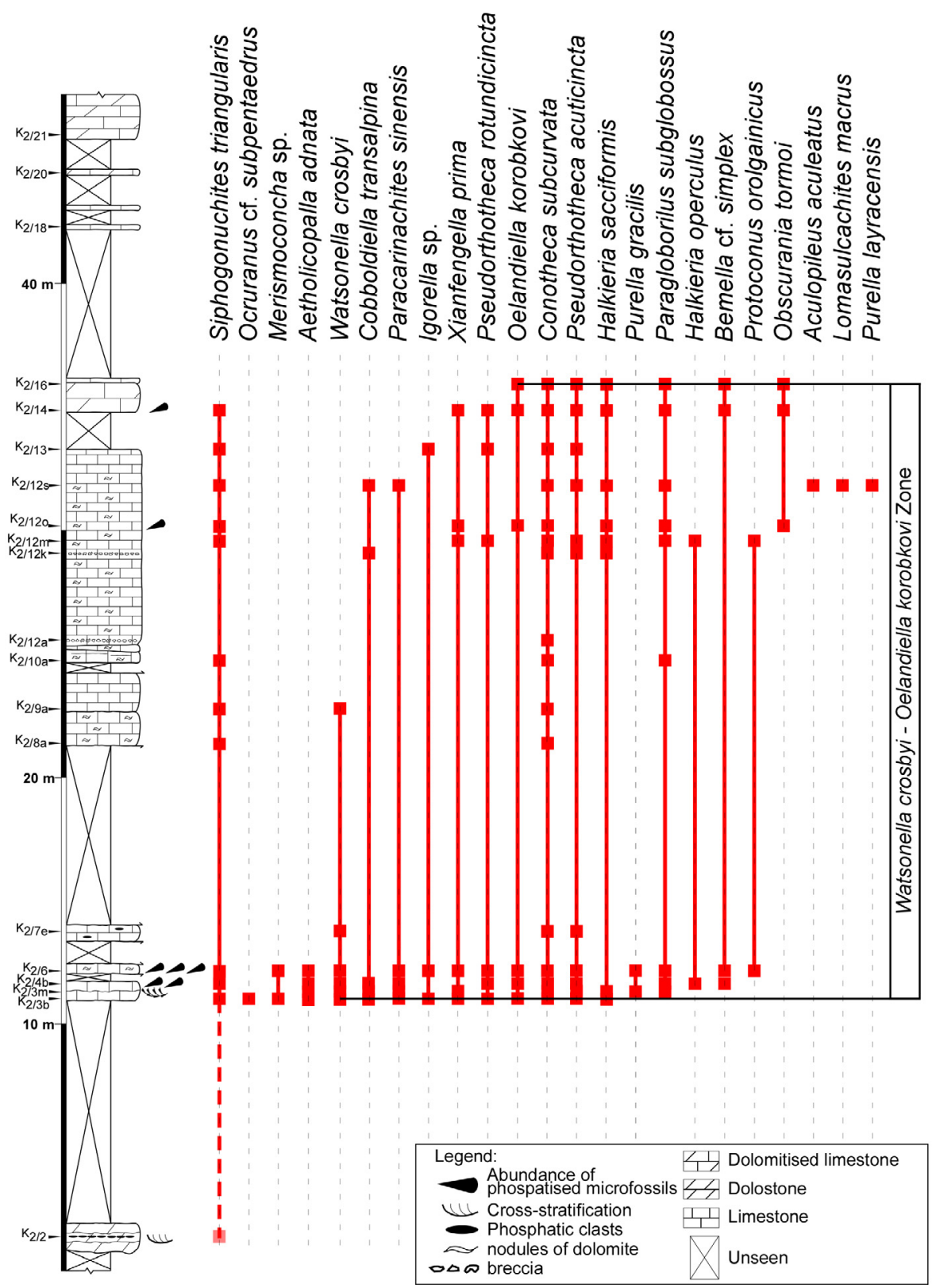

FIGURE 29. Stratigraphic range of taxa identified in section K2 (Marcou) and new biozone reported.

Kyrgyzstan; and the Pseudorthotheca costata to Rhombocorniculum cancellatum zones of the Chulaktau and Shabakty formations in Aktugay, Kazakhstan (Missarzhevsky and Mambetov, 1981). W. crosbyi, which first appears at the base of the Tommotian (Figure 34), rarely extends into the Atdabanian (Chapel Island and Cluslett formations, Watsonella crosbyi to Camenella baltica zones, Little Dantzic Cove, southeastern Newfoundland; Landing, 1989) or the Botoman (A to C Members, Sellick Hill Formation, Bemella communis to Stenotheca drepanoida SSF zones, Myoponga Beach
Fleurieu Peninsula; Gravestock et al., 2001). Aetholicopalla adnata has been reported from the Atdabanian and Toyonian Stages (Cambrian stages 3 and 4; Figure 34) of Australia (Parara Limestone and Kooliwurtie Limestone members, Abadiella huoi trilobite Zone, Arrowie; Stansbury Limestone, Pelagiella madianensis Zone, Port Julia, Yorke Peninsula; Parara Limestone Member, Kulpara Formation, Abadiella huoi Zone, Horse Gully and Ardrossan, Yorke Peninsula; Ajax Limestone, Abadiella huoi and Pararaia tatei Zone, Mount Scott range, Flinders Ranges; Bengtson et 


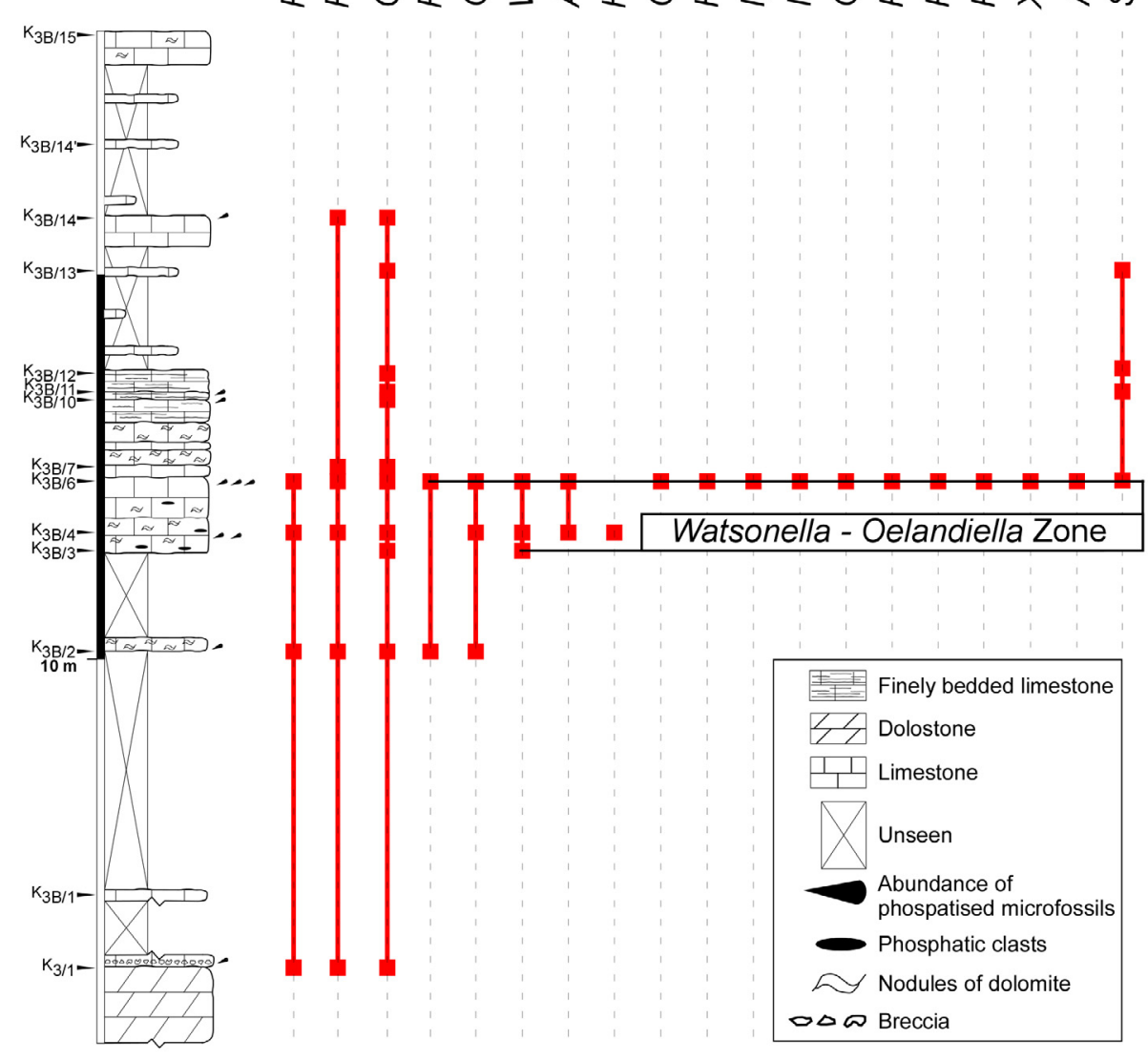

FIGURE 30. Stratigraphic range of taxa identified in section K3B (Marcou) and new biozone reported.

al., 1990 ; Gravestock et al., 2001), Germany (Lower Ludwigsdorf Member, Charlottenhof Formation, Görlitz Syncline; Elicki, 1998) and Antarctica (allochthonous boulders, Pararaia tatei trilobite Zone, King George Island; Wrona, 2004).

Those results enable the erection of a new biozone in the Montagne Noire: the Watsonella crosbyi-Oelandiella korobkovi Interval Zone. An Interval Zone corresponds to the body of fossiliferous strata between two specified biohorizons, the boundaries being defined by the occurrence of the biohorizons selected for its definition (Murphy and Salvador, 1999). In the present study, the lower boundary of the Watsonella crosbyi-Oelandiella korobkovi Interval Zone is placed at the FAD of $W$. crosbyi and its upper boundary at the LAD $O$. korobkovi. The name of the present biozone is derived from the names of the boundary horizons, the name of the basal boundary preceding that of the upper boundary (Murphy and Salvador, 1999). The FAD of Watsonella crosbyi is selected as the basal boundary because this biohorizon is easily globally correlated. The upper boundary corresponds to the LAD of Oelandiella korobkovi as this taxon as a large geographic distribution (Siberia, China, Iran, Mogolia) useful for international correlation. In the four sections of Montagne Noire, the FAD of Watsonella crosbyi co-occurs with the FAD 


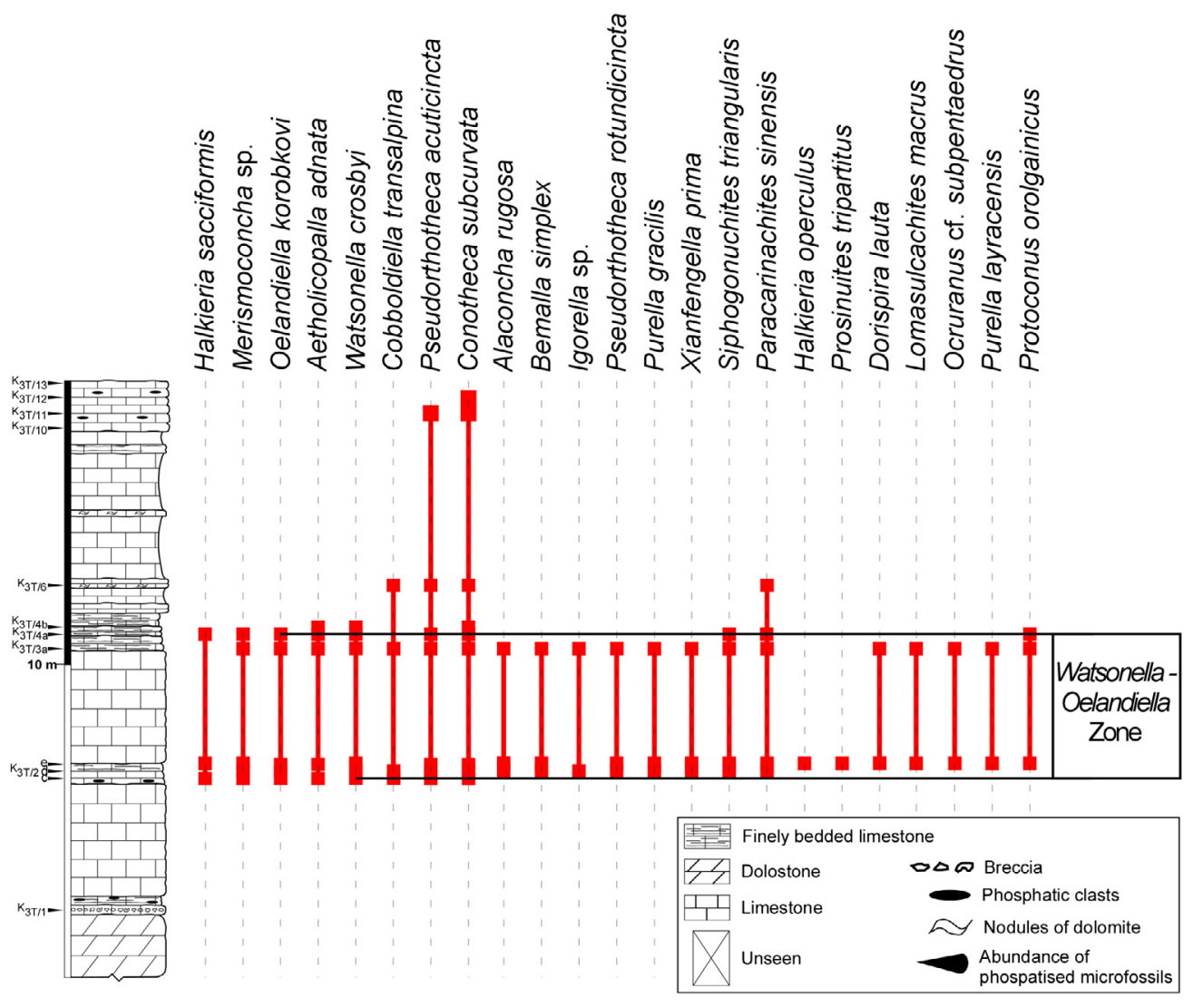

FIGURE 31. Stratigraphic range of taxa identified in section K3T (Marcou) and new biozone reported.

of Oelandiella korobkovi or occurs in upper levels than those with FAD of Oelandiella korobkovi whereas the LAD of Watsonella crosbyi occurs in lower to upper levels than those with LAD of Oelandiella korobkovi. Therefore, those two internationally correlatable biohorizons are combined into an Interval Zone.

The Watsonella crosbyi-Oelandiella korobkovi Interval Zone is identified in all the studied sections, although its range is not determined in section $\mathrm{K} 4$, where $W$. crosbyi and $O$. korobkovi only co-occur in one sample $(\mathrm{K} 4 / 4 \mathrm{a})$. Other taxa occurring in the $W$. crosbyi-O. korobkovi Interval Zone are Ocruranus cf. subpentaedrus (absent in section K4), Halkieria sacciformis, Halkieria operculus, Siphogonuchites triangularis, Pseudorthotheca acuticincta, Conotheca subcurvata, Pseudorthotheca rotundicincta, Aetholicopalla adnata, and Xianfengella prima (Figures 29-33).

This biozone can be internationally correlated. In the Yangtze Platform, it is correlated with the Watsonella crosbyi Assemblage Zone (Tommotian), defined by the FAD of $W$. crosbyi and the LAD of Oelandiella korobkovi and Aldanella yanjiahensis (Steiner et al., 2007), although Aldanella is absent in the French assemblage. In addition, Paragloborilus subglobosus, Ocruranus subpentaedrus, and Paracarinachites sinensis, characteristic of the $W$. crosbyi-O. korobkovi Zone from the Montagne Noire, are also known from the $W$. crosbyi Zone of China. Correlation is also possible with the lower Aldanella attleborensis Assemblage Zone of Massachussets (Landing, 1988), defined by the co-occurrence of $W$. crosbyi and $A$. attleborensis (correlation of the FAD of $W$. crosbyi), although Aldanella is absent in the Montagne Noire. The base of the French biozone also correlates with the base of the $W$. crosbyi Zone in Newfoundland (Landing et al., 1989), as it is defined by the FAD of $W$. crosbyi (with undetermined Helcionella). In Mongolia, the base of the $W$. crosbyi Range Zone is also correlatable with the base of the French biozone (Esakova and Zhegallo, 1996). The W. crosbyi Zone of Mongolia (Esakova and Zhegallo, 1996) is otherwise characterised by the co-occurrence of $W$. crosbyi and $O$. korobkovi (Esakova and Zhegallo, 1996; who also report the co-occurrence of Halkieria sacciformis, Ilsanella uniformis, Obtusoconus ampla, Obtusoconus honorabilis, and Postacanthella elegans). This 


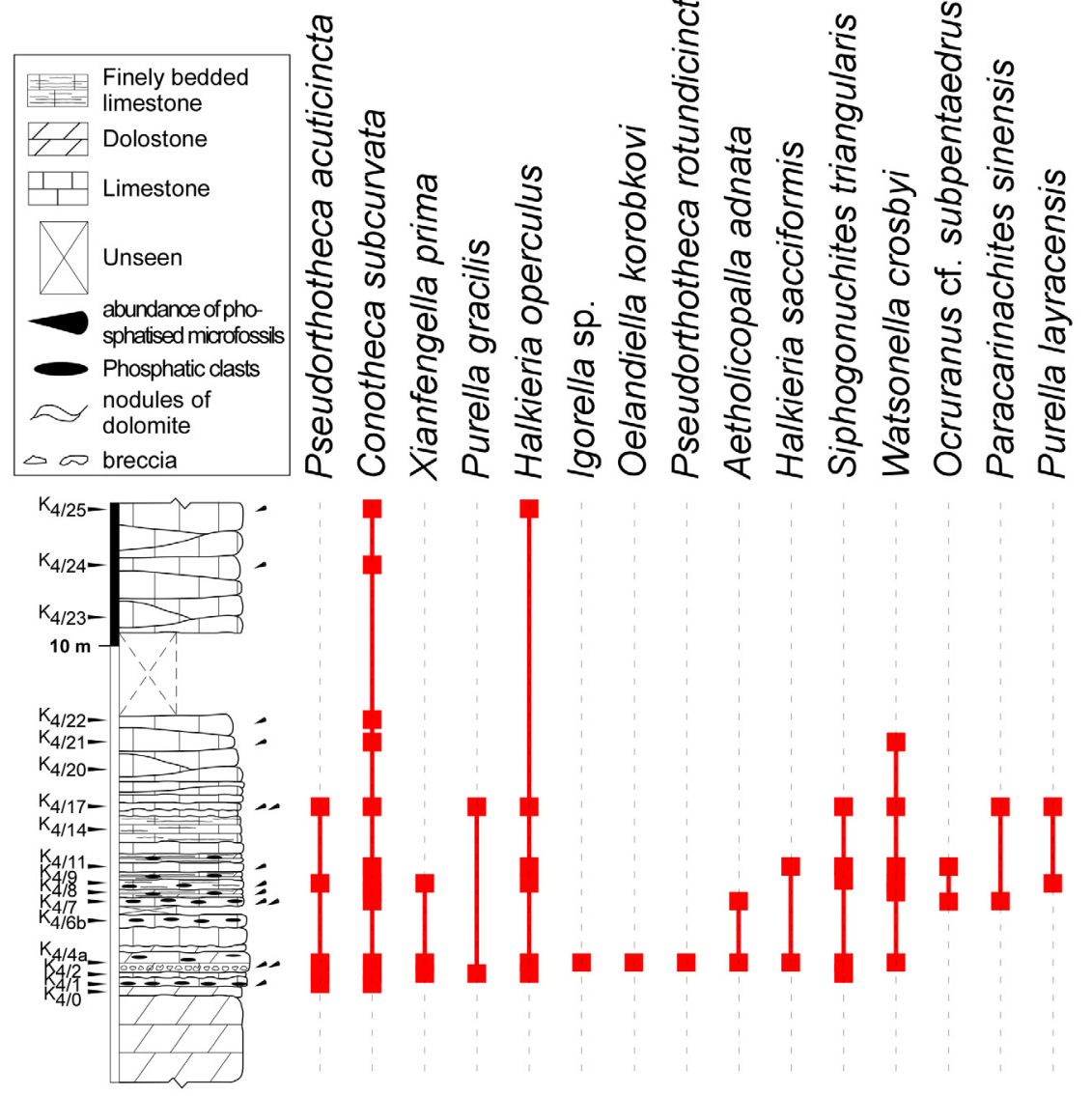

FIGURE 32. Stratigraphic range of taxa identified in section K4 (Saint Geniès de Varensal).

biozone was formerly dated from the Atdabanian (Voronin et al., 1982; Esakova and Zhegallo, 1996) but Brasier et al. (1996) suggest a Tommotian age for this biozone based on several lines of evidence. This position was further followed by Gubanov (2002) and Li et al. (2011). In the Siberian Platform, the Heraultipegma sibirica Mollusc Zone (renamed Watsonella crosbyi Zone due to the synonymy of $H$. sibirica and $W$. crosbyi) is defined by the stratigraphic range of $W$. crosbyi. Therefore, its base correlates with the base of the French Watsonella crosbyi-Oelandiella korobkovi Zone. O. korobkovi is also known from the $W$. crosbyi Zone in Siberia. Correlation of the biozone erected in the Heraultia Limestone is not directly possible with the microfaunal associations of Iran because $W$. crosbyi is not known from this region. However, O. korokbovi is reported in the Upper-Shale Member of the Soltanieh Formation along with Bemella sp. (Hamdi et al., 1989).

Finally, the reassessment of the microfauna of the Heraultia Limestone allows a revision of the lower Cambrian stratigraphy of the entire Montagne Noire. The Marcou Formation, which contains the Nemakit-Daldynian/Tommotian Heraultia Limestone, cannot be any more correlated with the Botoman/Toyonian Lastours Formation (Figure 34). Although some of the reported taxa display long stratigraphic ranges, starting at the Ediacaran/ Cambrian boundary (such as Halkieria sacciformis and Pseudorthotheca rotundicincta), ten species exclusively reported from the Nemakit-Daldynian and/or Tommotian of other regions are present. Therefore, the faunal assemblage of the Heraultia Limestone is most likely Nemakit-Daldynian to Tommotian in age. The base of the Atdabanian cannot be regionally identified because the index fossils of its base and correlative interval are not found in the studied sections, which are totally depleted of usually common Adtabanian fossils, such as archaeocyath, echinoderm, or trilobite remains. 


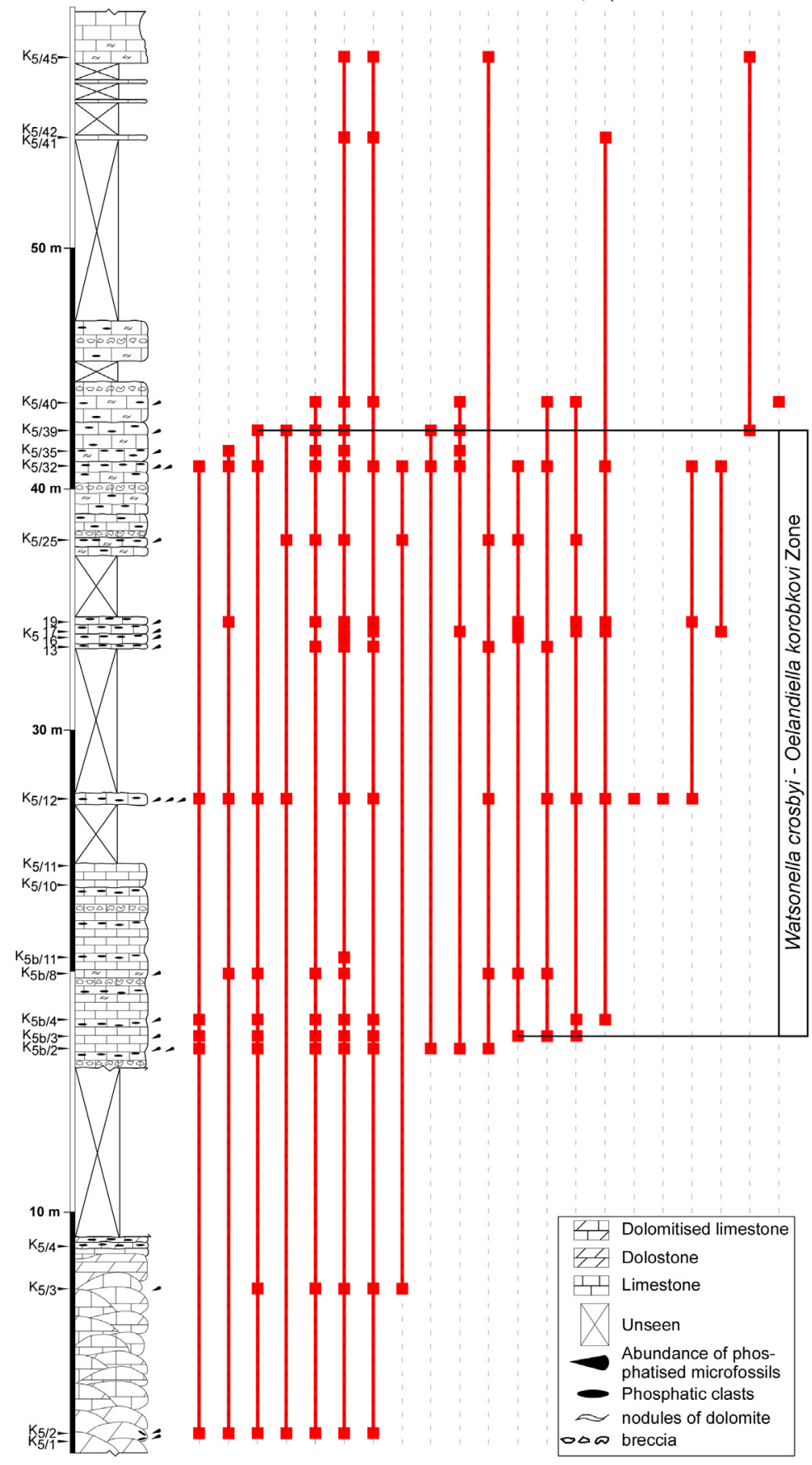

FIGURE 33. Stratigraphic range of taxa identified in section K5 (Saint Geniès de Varensal) and new biozone reported. 


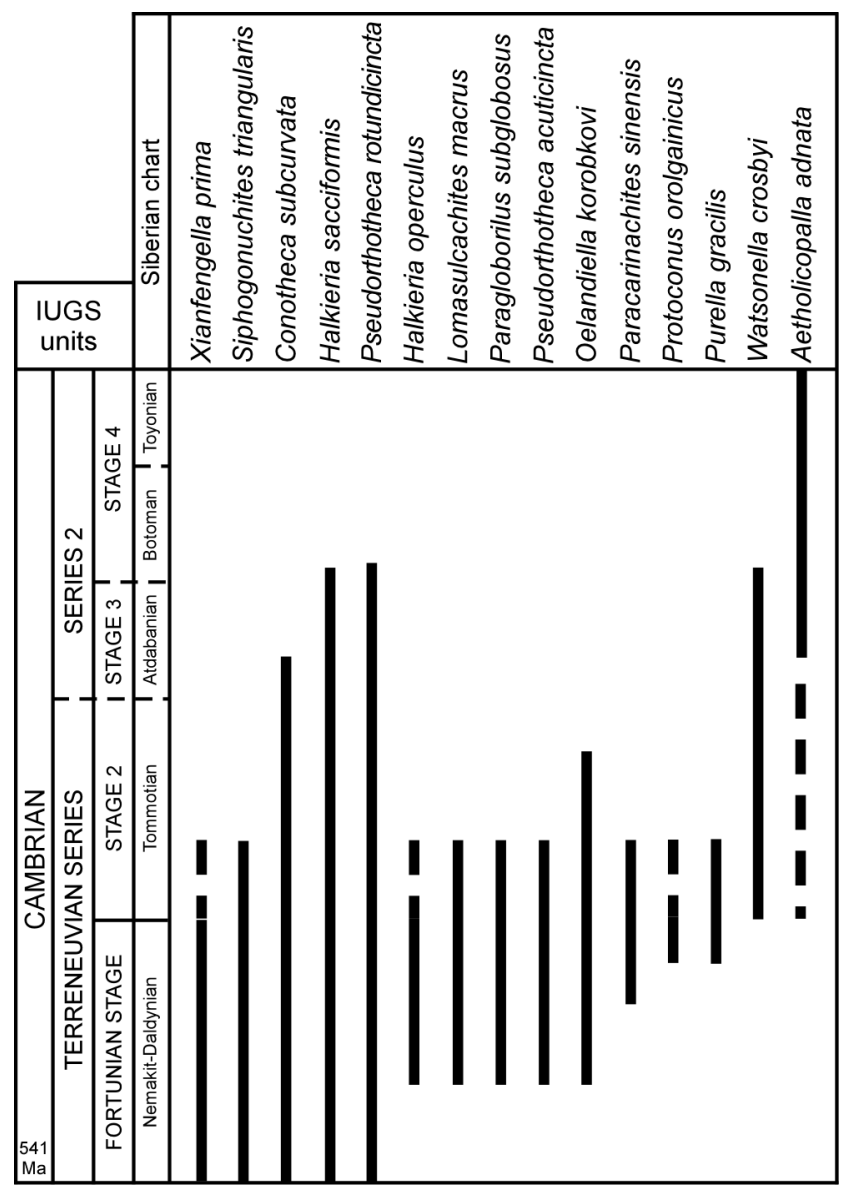

FIGURE 34. Composite ranges of widely distributed taxa present in the studied sections (for references, see the sec tion 'other occurrences' for each of the taxa). The Siberian stratigraphic chart is reported here due to its most commor use.

\section{REGIONAL PALEO(BIO)GEOGRAPHIC IMPLICATIONS}

The chronostratigraphic reassessment of the Heraultia Limestone Member and the whole Marcou Formation points to a distinct episode of carbonate productivity that extended across the Nemakit-Daldynian/Tommotian transition in, at least, part of the Montagne Noire platform.

In the southern Montagne Noire, some discontinuous limestone layers and beds embedded in the lower part of the Marcory Formation, rich in chancellorids (Allonia tripodophora and Chancelloria sp.) and hyoliths (Biconulites sensu Berger et al., 1993) were described by Geyer $(1984,1986)$ and Álvaro et al. (1998). The only biostratigraphic control of the overlying Marcory Formation is based on the occurrence, in its upper part, of the ichnofossils Psammichnites gigas and Taphrelminthopsis sp., suggesting a Tommotian-Atdabanian boundary interval age, and the Atdabanian
FAD of trilobites (Blayacina miqueli) in a correlatable limonitised sandstone (Geyer, 1992; Álvaro and Vizcaïno, 1999; Álvaro et al., in press).

Other phosphatised carbonate packages of latest Ediacaran-earliest Cambrian age are present in the western Mediterranean region of West Gondwana (Álvaro et al., 2000, 2010). This region contains, from present SW to NE, the Atlas rift of Morocco prolonged into the Ossa-Morena rift of Iberia, and the passive margins of the CantabroIberian Basin (Cantabrian and West AsturianLeonese zones and Sierra de la Demanda and Iberian Chains changing palaeogeographically into the distal Centro-Iberian Zone), laterally continued, after the Variscan Ibero-Armorican Arc, into the Pyrenees, Montagne Noire, and Sardinian platforms (Álvaro et al., 2010; figure 1A). Although a certain diachronicity can be recognised in the record of this composite episode of phosphogenesis and carbonate productivity, probably controlled by the poleward migration of West Gondwana 
(Álvaro et al., 2000), some neighbouring platforms exhibit similar processes. Those that did not record the Cadomian orogeny display thick carbonate successions with phosphoritic interbeds, such as: (1) in the Atlas Mountains of Morocco, the Taguedit Bed (Tabia Member, Adoudou Formation; Álvaro and Subías, 2011; Álvaro, in press); (2) in the Central-Iberian (Variscan) Zone of Iberia, the middle part of the Río Huso Group and the Cloudina-bearing Membrillar and Fuentes Olistostromes or Fuentes Member in the Valdelacasa Anticline, the lbor Group of the Ibor and Navalpino Anticlines, and the Fontanarejo phosphorites of the Valdelacasa Anticline (Perconig et al., 1986; Gabaldón López et al., 1987; López Díaz, 1994; Santamaría, 1996; Vidal et al., 1994, Valladares et al., 2000, 2002); (3) in the Cantabrian (Variscan) Zone, the lower phosphatic member of the Herrería Formation (Palacios and Vidal, 1992; Álvaro et al., 2010); and (4) in the Iberian Chains, the Codos phosphoritic Bed (Paracuellos Formation) of the Iberian Chains (Álvaro and Blanc-Valleron, 2002; Álvaro et al., 2008; Álvaro et al., 2010).

The faunal assemblage of the Heraultia Limestone exhibits strong affinities with other subtropical carbonate platforms, such as those described in the Siberian Platform and South China (or Yangtze Platform, northern Gondwana). The transgression that characterises the end of the Cadomian Orogeny in West Gondwana may have led to the opening of biogeographic connections throughout low-latitude platforms allowing the immigration of archaeocyaths from the Siberian Platform (Debrenne, 1991; Rowland and Shapiro, 2002) and SSFs from Siberia and northern Gondwana to some platforms of West Gondwana, such as the Montagne Noire.

\section{CONCLUSIONS}

The reassessment of the microfauna of the Heraultia Limestone Member, Marcou Formation, has lead to the identification of 28 species and 3 morphotypes (including 2 new ones, 6 reported for the first time, 13 reassigned, and 7 already reported by Kerber, 1988), dominated by molluscs (helcionellids, ?polyplacophors and other problematic molluscs), and abundant orthothecid hyoliths, tubular problematics, and a few problematica (Acupuleus, Aetholicopalla and Paracarinachites). Two new species are defined, Obscurania tormoi Devaere, sp. nov. and Alaconcha rugosa Devaere, sp. nov. The global stratigraphic range of each species has been established and argues for a Terre- neuvian age of the microfossil assemblage, including the Watsonella crosbyi - Oelandiella korobkovi Interval Zone. The FAD of Watsonella crosbyi and the associated fauna can be correlated internationally, and this mollusc species can be considered as a suitable candidate for the definition of the Terreneuvian/Cambrian Stage 2 boundary. In contrast, the absence of Aldanella attleborensis in the Montagne Noire questions its relevance for biostratigraphic correlation in the western Mediterranean region.

The presence of a thick Tommotian carbonate unit (Marcou Formation, $1300 \mathrm{~m}$ thick) in the northern Montagne Noire, bearing distinct phosphogenic processes, questions the poisoning effects of the Cadomian Orogeny in some areas of West Gondwana, where Cadomian tectono-thermal effects are not recorded and a phosphorite/carbonate association is well established across the Ediacaran-Cambrian boundary interval, such as the Atlas Mountains of Morocco, the Central-Iberian Zone of Iberia and the Montagne Noire.

\section{ACKNOWLEDGEMENTS}

The authors are grateful to N. Tormo, E. Monceret, and D. Vizcaïno for guidance and discussions in the field. L.D. would like to acknowledge J. S. Peel for the discussions. L.D. benefited from a research fellowship conducted at the Freie Universität Berlin, funded by the DAAD (German Academic Exchange Service). This research was also funded by the project CGL2010-19491 from Spanish MICINN and EU-FEDER. This work is a contribution to ANR project (JC07-194555) "Paleogeographic, paleoecologic, and paleoenvironmental controls on the evolution of bottom-level communities during Cambrian times," financed by CNRS-USAR. M. Steiner was part of Forschergruppe FOR 736 and supported by DFG grant STE 814/3-2.

\section{REFERENCES}

Ahman, E. and Martinsson, A. 1965. Fossiliferous Lower Cambrian at Aspelund on the Skaggenas peninsula. Geologiska Foreningens i Stockholm Fordhandlingar, 87:139-51.

Aksarina, N.A. and Pelman, Y.L. 1978. Kembriiskie brakhiopodyi dvustvorchatye molliuski Sibiri. Trudy Instituta Geologii i Geofiziki, Sibirskoye otdeleniye Akademiya Nauka SSSR, 362:5-178. (In Russian)

Álvaro, J.J. In press. Late Ediacaran syn-rift/post-rift transition and related fault-driven hydrothermal systems in the Anti-Atlas Mountains, Morocco. Basin Research. 
Álvaro, J.J. and Blanc-Valleron, M.M. 2002. Stratigraphic and structural framework of the Neoproterozoic Paracuellos Group, Iberian Chains, NE Spain. Bulletin de la Société géologique de France, 173(3):27-35.

Álvaro, J.J. and Clausen, S. 2010. Morphology and ultrastructure of epilithic versus cryptic, microbial growth in lower Cambrian phosphorites from the Montagne Noire, France. Geobiology, 8:89-100.

Álvaro, J.J. and Subías, I. 2011. Interplay of phosphogenesis and hydrothermalism in the latest Ediacaran rift of the High Atlas, Morocco. Journal of African Earth Sciences, 59:51-60.

Álvaro, J.J. and Vizcaïno, D. 1999. Biostratigraphic significance and environmental setting of the trace fossil Psammichnites in the Lower Cambrian of the Montagne Noire (France). Bulletin de la Société Géologique de France, 170:821-828.

Álvaro, J.J., Bauluz, B., Gil Imaz, A., and Simón, J.L. 2008. Multidisciplinary constraints about Cadomian compression and early Cambrian extension in the Iberian Chains, NE Spain. Tectonophysics, 461:215227.

Álvaro, J.J., Monceret, E., Monceret, S., Verraes, G., and Vizcaïno, D. 2010. Stratigraphic record and palaeogeographic context of the Cambrian Epoch 2 subtropical carbonate platforms and their basinal counterparts in SW Europe, west Gondwana. Bulletin of Geosciences, 85:573-584.

Álvaro, J.J., Bauluz, B., Clausen, S., Devaere, L., Gil Imaz, A., Monceret, E., and Vizcaïno, D. In press. Stratigraphic review of the Cambrian-Lower Ordovician volcanosedimentary complexes from the northern Montagne Noire, France. Stratigraphy.

Álvaro, J.J., Courjault-Radé, P., Chauvel, J.J., Dabard, M.P., Debrenne, F., Feist, R., Pillola, G.L., Vennin, E., and Vizcaïno, D. 1998. Nouveau découpage stratigraphique des séries cambriennes des nappes de Pardailhan et du Minervois (versant sud de la Montagne Noire, France). Géologie de France, 2:3-12.

Álvaro, J.J., Rouchy, J.M., Bechstädt, T., Boucot, A., Boyer, F., Debrenne, F., Moreno-Eiris, E., Perejón, A., and Vennin, E. 2000. Evaporitic constraints on the southward drifting of the western Gondwana margin during early Cambrian times. Palaeogeography, Palaeoclimatology, Palaeoecology, 160:105-122.

Azmi, R.J. and Pancholi, V.P. 1983. Early Cambrian (Tommotian) conodonts and other shelly microfauna from the upper Krol of Mussoorie Syncline, Garhwal Lesser Himalaya with remarks on the PrecambrianCambrian boundary. Himalayan Geology, 11:360372.

Babcock, L.E. and Peng, S.C. 2007. Cambrian chronostratigraphy: current state and future plans. Palaeogeography, Palaeoclimatology, Palaeoecology, 254: 6266.

Barrande, J. 1881. Système Silurien de centre de la Bohême. Volume VI: Acéphales. Système Silurien de Centre de la Bohême. Volume VI: Acéphales:1-342.
Bengtson, S. 1985a. Redescription of the Lower Cambrian Halkieria obliqua Poulsen. Geologiska Fiff eningens i Stockholm Fiff handlingar, 107(2):101-106.

Bengtson, S. 1985b. Taxonomy of disarticulated fossils. Journal of Paleontology, 59:1350-1358.

Bengtson, S. 1992. The cap-shaped Cambrian fossil Maikhanella and the relationship between Coeloscleritophora and mollusks. Lethaia, 25:401-420.

Bengtson, S. and Conway Morris, S. 1984. A comparative study of Lower Cambrian Halkieria and Middle Cambrian Wiwaxia. Lethaia, 17:307-329.

Bengtson, S. and Fletcher, T.P. 1983. The oldest sequence of skeletal fossils in the Lower Cambrian of southeastern Newfoundland. Canadian Journal of Earth Sciences, 20:525-536.

Bengtson, S., Conway Morris, S., Cooper, B.J., Jell, P.A., and Runnegar, B.N. 1990. Early Cambrian fossils from South Australia. Memoirs of the Association of Australasian Palaeontologists, 9:1-364.

Berg-Madsen, V. and Peel, J.S. 1978. Middle Cambrian monoplacophorans from Bornholm and Australia and the systematic position of the bellerophontiform molluscs. Lethaia, 11(2):113-125.

Berger, G.M., Boyer, F., Debat, P., Demange, M., Freytet, P., Marchal, J.P., Mazeas, H., and Vautrelle, C. 1993. Notice explicative de la feuille de Carcassonne (n 1037) de la Carte géologique de la France, 78 p. Editions BRGM, Orléans.

Bergeron, J. 1887. Sur la constitution géologique de la Montagne Noire. Comptes-Rendus de l'Académie des Sciences de Paris, 104:530-532.

Bergeron, J. 1889. Etude géologique du massif ancien situé au sud du "plateau central». Thèse de la faculté des Sciences de Paris, Annales de Sciences Géologiques, 22:1-362.

Bhatt, D.K., Mamgain, V.D., and Misra, R.S. 1985. Small Shelly Fossils of early Cambrian (Tommotian) age from Chert-Phosphorite Member, Tal Formation, Mussoorie Syncline, Lesser Himalaya, India and their chronostratigraphic evaluation. Journal of the Palaeontological Society of India, 30:92-102.

Bhatt, D.K., Mamgain, V.D., Misra, R.S., and Srivastava, J.P. 1983. Shelly microfossils of Tommotian age (lower Cambrian) from the Chert-Phosphorite Member of the Lower Tal Formation, Maldeota, Dehradun district, Uttar Pradesh. Geophytology, 13:116-123.

Billings, E. 1871. Proposed new genus of Pteropoda [Hyolithellus]. Canadian Naturalist and Geologist, 6:213-233, 240.

Billings, E. 1872. On some fossils from the primordial rocks of Newfoundland. Canadian Naturalist and Quarterly Journal of Science, 6:465-479.

Bogdanoff, S., Donnot, M., and Ellenberger, F. 1984. Feuille de Bédarieux et notice explicative. Carte géologique détaillée de la France au 1/50 000e (no. 988). BRGM, Orléans.

Bokova, A.P. 1990. New lower Cambrian gastropods from the Siberian platform. Paleontological Journal, 24:134-136. 
Brasier, M.D. 1984. Microfossils and small shelly fossils from the Lower Cambrian Hyolithes Limestone at Nuneaton, English Midlands. Geological Magazine, 121:229-253.

Brasier, M.D. and Hewitt, R.A. 1981. Faunal Sequence with the Lower Cambrian "Non-Trilobite Zone" (s. I.) of the Central England and correlated regions, p. 2933. In Taylor, M. E. (ed.), Short Papers for the Second International Symposium on the Cambrian System. U.S. Geological Survey Open-File Report:81743.

Brasier, M.D. and Singh, P. 1987. Microfossils and Precambrian-Cambrian boundary stratigraphy at Maldeota, Lesser Himalaya. Geological Magazine, 124:323-45.

Chen, P. 1984. Discovery of Lower Cambrian Small Shelly Fossils from Jijiapo, Yichang, West Hubei and its significance. Professional Papers of Stratigraphy and Palaeontology, 13:49-64. (In Chinese with English abstract)

Chen, Y. and Zhang, S. 1980. Small shelly fossils from the early Lower Cambrian, Sonlingpo, Eastern Yangtze Gorges. Geological Review, 26:190-197. (In Chinese)

Chen, M., Chen, Y., and Zhang, S. 1981. The Small shelly fossil assemblage in the limestone of the uppermost part of the Dengying Formation at Songlingpo, Yichang. Journal of the Wuhan College of Geology, Earth Science, 1:32-41. (In Chinese with English abstract)

Clausen, S. and Álvaro, J.J. 2007. Lower Cambrian shelled phosphorites from the northern Montagne Noire, France, p. 17-28. In Alvaro, J.J., Aretz, M., Boulvain, F., Munnecke, A., Vachard, D., and Vennin, E. (eds.), Palaeozoic Reefs and Bioaccumulations: Climatic and Evolutionary Controls. Geological Society, London, Special Publications, 275.

Cobbold, E.S. 1919. Cambrian hyolithid from Hartshill in the Nuneaton district (Warwickshire). Geological Magazine, 56:149-158.

Cobbold, E.S. 1921. The Cambrian horizons of Comley (Shropshire) and their Brachiopoda, Pteropoda, Gasteropoda, etc. Quarterly Journal of the Geological Society, Ixxvi:325-386.

Cobbold, E.S. 1931. Additional fossils from the Cambrian rocks of Comley, Shropshire. Quarterly Journal of the Geological Society, 87:459-512.

Cobbold, E.S. 1935. Lower Cambrian from Herault, France. The Annals and Magazine of Natural History, 16:25-48.

Cobbold, E.S. 1936. The Conchostraca of the Cambrian area of Comley, Shropshire, with a note on a new variety of Atops reticulatus (Walcott). Quarterly Journal of the Geological Society, 92:221-NP.

Cobbold, E.S. and Pocock, R.W. 1934. The Cambrian area of Rushton (Shropshire). Philosophical Transactions of the Royal Society B, 223:305-409.
Conway Morris, S. and Caron, J.B. 2007. Halwaxiids and the early evolution of lophotrochozoans. Science, 315:1255-1258.

Conway Morris, S. and Menge, C. 1991. Cambroclaves and paracarinachitids, early skeletal problematica from the Lower Cambrian of south China. Palaeontology, 34(2):357-397.

Conway Morris, S. and Peel, J.S. 1990. Articulated halkieriids from the Lower Cambrian of north Greenland. Nature, 345:802-805.

Courtessole, R. 1973, Le Cambrien moyen de la Montagne Noire. Biostratigraphie. Imprim d'Oc, Toulouse.

Cuvier, G. 1797. Tableau élémentaire de l'histoire naturelle des animaux. Baudoin, Paris.

Daily, B. 1956. The Cambrian in north Australia, p. 91147. In Rodgers, J. (ed.), El Sistema Cambrico, su paleogeografia y el problema de su base. Report of the 20th International Geological Congress, Mexico, 2.

Daily, B. 1976. The Cambrian of the Flinders Ranges, p. 15-19. In Thompson, B.P. Daily, B., Coats, R.P., and Forbes, B.G. (eds.), Late Precambrian and Cambrian Geology of the Adelaide Geosyncline and Stuart Shelf, South Australia, 25th International Geological Congress, Excursion Guide 33A. Canberra, Progress. Press.

De Blainville, H.M. 1816. Prodrome d'une nouvelle distribution systématique du règne animal. Bulletin de la Société Philomatique de Paris, 8.

Debrenne, F. 1964. Archaeocyatha. Contribution à l'étude des faunes cambriennes du Maroc, de Sardaigne et de France. Notes et Mémoire du Service Géologique du Maroc, 179(1):1-265.

Debrenne, F. 1991. Extinction of the Archaeocyatha. Historical Biology, 5:95-106.

Debrenne, F. and Courjault-Radé, P. 1986. Découverte de faunules d'Archéocyathes dans l'Est des monts de Lacaune, flanc nord de la Montagne Noire. Implications biostratigraphiques. Bulletin de la Société géologique de France, 2:285-292.

Debrenne, F. and Courjault-Radé, P. 1994. Répartition paléogéographique des archéocyathes et délimitation des zones intertropicales au Cambrien inférieur. Bulletin de la Société géologique de France, $8^{\mathrm{e}}$ série, 165(5):459-467.

Demidenko, Y.E. and Parkhaev, P.Y. 2006. Taxonomic diversity of the early Cambrian small shelly fauna of China, p. 492-505. In Evolution of the Biosphere and Biodiversity: Contributions to A.Yu. Rozanov's 70th Birthday. KMK, Moscow.

Devaere, L., Clausen, S., Álvaro, J.J., Peel, J.S., and Vachard, D. Submitted. Terreneuvian orthothecid (Hyolitha) digestive tracts from northern Montagne Noire, France: taphonomic, ontogenetic and phylogenetic implications. PLOS ONE. 
Donnot, M. and Guérangé, B. 1978. Le synclinorium cambrien de Brusque. Implications stratigraphiques et structurales dans les Monts de l'Est de Lacaune (Tarn, Aveyron, Hérault). Versant nord de la Montagne Noire. Bulletin du BRGM, 4:333-363.

Duan, C. 1984. Small shelly fossils from the Lower Cambrian Xihaoping Formation the Shennongjia district, Hubei province - hyoliths and fossil skeletons of unknown affinities. Bulletin of the Tianjin Institute of Geology and Mineral Resources, 7:141-188. (In Chinese with English abstract)

Dzik, J. 1978. Larval development of hyolithids. Lethaia, 11:293-299.

Dzik, J. 1991. Is fossil evidence consistent with traditional views of the early metazoan phylogeny? p. 4756. In Simonetta, A. and Conway Morris, S. (eds.), The Early Evolution of Metazoa and the Significance of Problematic Taxa. Cambridge Univ. Press, London.

Egorova, L.I. and Savitzky, V.E. 1969. Stratigrafiya i biofatsii Kembriya Sibirskoj platformy (Zapadnoye Prianabare). [Stratigraphy and biofacies of the Cambrian of the Siberian platform (western Anabar uplift)]. Trudy SNIIGGIMS 43:1-408. (In Russian)

Elicki, O. 1998. First report of Halkieria and enigmatic globular fossils from the central European Marianian (Lower Cambrian, Görlitz syncline, Germany). Revista Española de paleontological, $n^{\circ}$ extraordinario, Homenaje al prof. Gonzalo Vidal: 51-64.

Elicki, O. and Schneider, J. 1992. Lower Cambrian (Atdabanian/Botomian) shallow-marine carbonates of the Görlitz Synclinorium (Saxony/Germany). Facies, 26:55-66.

Esakova, N.V. and Zhegallo, E.A. 1996. Fauna and biostratigraphy of the Lower Cambrian of Mongolia. Nauka, Moscow. (In Russian)

Fedorov, A.B. 1984. New representatives of skeletal organic matter in the stratotype sections of the Precambrian-Cambrian of the Siberian platform (Aldan and Kotui rivers), p. 5-9. In New Species of Ancient Invertebrates and Plants from Oil and Gas Provinces of Siberia. Sib. Nauchno-Issled. Inst. Geol., Geof. Mineral. Syr'ya (SNIIGGiMS), Novosibirsk. (In Russian)

Feng, W.M. and Sun, W.G. 2003. Phosphate replicated and replaced microstructure of molluscan shells from the earliest Cambrian of China. Acta Palaeontologica Polonica, 48:21-30.

Feng, W., Mu, X., and Kouchinsky, A.V. 2001a. Hyolithtype microstructure in a mollusc-like fossil from the Early Cambrian of Yunnan, China. Lethaia, 34:303308.

Feng, W.M., Qian, Y., and Rong, Z.Q. 1994. Study of Monoplacophora and Gastropoda from the Lower Cambrian Xinji Formation in Ye Xian, Henan. Acta Micropalaeontologica Sinica, 11(1):1-19. (In Chinese with English abstract)
Feng, W., Sun, W.G., and Qian, Y. 2000. Earliest Cambrian Monoplacophora in northeastern Yunnan with some new genera and species. Acta Micropalaeontologica Sinica, 17:365-377.

Feng, W., Sun, W., and Qian, Y. 2001b. Skeletalization characters, classification and evolutionary significance of early Cambrian monoplacophoran maikhanellids. Acta Palaeontologica Sinica, 40(2):195-213.

Fisher, D.W. 1962. Small conoidal shells of uncertain affinities, p. W98-W143. In Moore, R.C. (ed.), Treatise on Invertebrate Paleontology, Part W, Miscellanea. Geological Society of America and University of Kansas Press, Boulder, Colorado, and Lawrence, Kansas, 98-143.

Fonin, V.D. and Smirnova, T.N. 1967. New group of problematic Early Cambrian organisms and methods of preparing them. Paleontological Journal, 2:7-18.

Gabaldón López, V., Hernández Urroz, J., Lorenzo Álvarez, S., Picart Boira, J., Santamaría Casanovas, J., and Solé Pont, F.J. 1987. Sedimentary facies and stratigraphy of Precambrian-Cambrian phosphorites on the Valdelacasa anticline, Central Iberian zone, Spain, p. 422-428. In Cook, P.J. and Shergold, J.H. (eds.), Phosphate Deposits of the World. Vol. 2. Proterozoic and Cambrian Phosphorites. Cambridge Univ. Press, Cambridge.

Geyer, G. 1986. Mittelkambrische Mollusken aus Marokko und Spanien. Senckenbergiana Lethaia, 67:55-118.

Geyer, G. 1992. A re-evaluation of Blayacina COBBOLD 1932 and Thoralaspis HUPE 1953 (Trilobita: Redlichiida). Paläontologische Zeitschrift, 66:92-113.

Geyer, G. 1994. Middle Cambrian mollusks from Idaho and early conchiferan evolution. New York State Museum Bulletin, 481(1):69-86.

Geyer, M. 1984. Beiträge zur Geologie des westlichen Minervois und Cabardès am Südwestrand der Montagne Noire (Dept. Aude, Südwestfrankreich). Unpublished $P h D$ Thesis, University of Würzburg, Germany.

Gèze, B. 1949. Etude géologique de la Montagne Noire et des Cévennes méridionales. Mémoires de la Société géologique de France (nouvelle série), 62:1215.

Grabau, A.W. 1900. Palaeontology of the Cambrian terranes of the Boston basin. Occasional Papers of the Boston Society of Natural History, 4:601-694.

Grabau, A.W. and Shimer, H.W. 1909. North American Index Fossils, Invertebrates. A.G. Seiler and Co., New York.

Gravestock, I., Alexander, E.M., Demidenko, Y.E., Esakova, N.V., Holmer, L.E., Jago, J.B., Lin, T.M., Melnikova, L., Parkhaev, P.Y., Rozanov, A.Y., Ushatinskaya, G.T., Zang, W.I., Zhegallo E.A., and Zhuravelv, A.Y. 2001. The Cambrian biostratigraphy of the Stansbury basin, South Australia. Russian Academy of Sciences, Transactions of the Palaeontological Institute 282:1-344. 
Gubanov, A.P. and Peel, J.S. 1999. Oelandiella, the earliest Cambrian helcionelloid mollusc from Siberia. Palaeontology, 42:211-222.

Gubanov, A.P. and Peel, J.S. 2000. Cambrian monoplacophoran molluscs (Class Helcionelloida). American Malacological Bulletin, 15:139-145.

Gubanov, A.P., Kouchinsky, A.V., and Peel, J.S. 1999. The first evolutionary-adaptive lineage within fossil molluscs. Lethaia, 32:155-157.

Guérangé-Lozes, J. and Burg, J.P. 1990. Les nappes varisques du sud-ouest du Massif Central. Géologie de la France:71-106.

Guo, J., Li, Y., Han, J., Zhang, X., Zhang, Z., Ou, Q., Liu, J., Shu, D., Maruyama, S., and Komiya, T. 2008. Fossil association from the Lower Cambrian Yanjiahe Formation in the Yangtze Gorges area, Hubei, South China. Acta Geologica Sinica, 82(6):1124-1132. (In Chinese with English abstract)

Hamdi, B. 1995. Precambriam-Cambrian deposits in Iran. In Hushmandzadeh, A. (ed.), Treatise on the Geology of Iran 20. (In Farsi)

Hamdi, B., Brasier, M.D., and Jiang, Z. 1989. Earliest skeletal fossils from Precambrian-Cambrian boundary strata, Elburz Mountains, Iran. Geological Magazine, 126(3):283-289.

Havlíček, V. 1982. Lingulacea, Paterinacea, and Siphonotretacea (Brachiopoda) in the Lower Ordovician sequence of Bohemia. Sborník geologických ved. Paleontologie, 25:9-82.

He, T.G. 1980. Arthropoda, p. 182-197. In Yin, J.C. Ding, L.F., He, T.G., Li, S.L., and Shen, L.J. (eds.), the palaeontology and sedimentary environment of the Sinian system in Emei-Ganluo Area, Sichuan. Sichuan People's Publishing House, Chengdu. (In Chinese with English abstract)

He, T.G. 1981. Lower Cambrian (Meishucunian) sachitids and their stratigraphic significance. Journal of Chengdu College of Geology, 2:84-90. (In Chinese)

He, T.G. 1984. Discovery of Lapworthella bella assemblage from Lower Cambrian Meishucun Stage in Niuniuzhai, Leibo County, Sichuan province. Professional Papers of Stratigraphy and Paleontology, 13:23-34. (In Chinese with English abstract)

He, T.G. and Xie, Y. 1989. Some problematic small shelly fossils from the Meishucunian of the Lower Cambrian in the western Yangtze region. Acta Micropalaeontologica Sinica, 6:111-127. (In Chinese with English abstract)

He, T.G. and Yang, X.H. 1982. Lower Cambrian Meishucun Stage of the western Yangtze stratigraphic region and its small shelly fossils. Bulletin of the Chengdu Institute of Geological and Mineral Research, (3):69-95. (In Chinese with English abstract)

Holm, G. 1893. Sveriges Kambrisk-Siluriska Hyolithdae och Conularidae. Sveriges Geologiska Undersökning, Afhandlingar och Uppsatser C, 112:1172.
Jermak, V.V. and Pelman, Y.L. 1986. Some Cambrian mollusks and brachiopods of the Northern Kharaulakh Range, p. 188-200. In Zhuravleva, I.T. (ed.), Biostratigraphy and Paleontology of the Cambrian of Northern Asia. Proceedings of the Institute of the Geology and Geophysics of the Siberian Division of the Academy of Sciences of the USSR, 669, Nauka, Moscow. (In Russian)

Jiang, Z. 1980a. Monoplacophorans and gastropods fauna of the Meishucunian Stage from the Meishucun section, Yunnan. Acta Geologica Sinica, 2:112-123. (In Chinese with English abstract)

Jiang, Z. 1980b. The Meishucun Stage and fauna of the Jinning county, Yunnan. Bulletins of the Chinese Academy of Geological Sciences, Series I, 2(1):7592. (In Chinese with English abstract)

Jiang, Z. 1984. Evolution of early shelly metazoans and basic characteristics of Meishucun fauna. Professional Papers of Stratigraphic Palaeontology, 13:122. (In Chinese with English abstract)

Kerber, M. 1988. Mikrofossilien aus Unterkambrischen Gesteinen der Montagne Noire, Frankreich. Palaeontographica Abteilung A, 202:127-203.

Khomentovsky, V.V. and Karlova, G.A. 1989. The Vendian-Cambrian strata of the Dzhanda River and their analogues in the reference sections of eastern Siberia. Late Precambrian and early Paleozoic Siberia: current problems in stratigraphy. Inst. Geol. Geof. Sib. Otd. Akademiya Nauka SSSR (IGiG), Novosibirsk: 23-74. (In Russian)

Khomentovsky, V.V. and Karlova, G.A. 1993. Biostratigraphy of the Vendian-Cambrian beds and the lower Cambrian boundary in Siberia. Geological Magazine, 130(1):29-45.

Khomentovsky, V.V., Didenko, A.N., and Pyatiletov V.G. 1982. The Vendian of the western Anabar region: general stratigraphic conclusions, p. 3-30. In New Data on the Stratigraphy of the Late Precambrian of Siberia. Institute of Geology and Geophysics, Academy of Science USSR (IGiG), Novosibirsk. (In Russian)

Khomentovsky, V.V., Valkov, A.K., and Karlova, G.A. 1990. New data on the biostratigraphy of the Vendian-Cambrian transition strata in the middle Aldan River basin, p. 3-57. In Khomentovsky, V.V. and Gibsher, A.S. (eds.), Late Precambrian and Early Paleozoic of Siberia: Problems of the Regional Stratigraphy. Institute of Geology and Geophysics, Academy of Science USSR (IGiG), Novosibirsk. (In Russian)

Knight, J.B., Cox, L.R., Batten, R.L., and Yochelson, E.L. 1960. Systematic descriptions. Treatise on Invertebrate Paleontology. Mollusca, I(1):169-339.

Knoll, A.H., Grotzinger, J.P., Kaufman, A.J., and Kolosov, P. 1995. Integrated approaches to terminal Proterozoic stratigraphy: an example from the Olenek Uplift, northeastern Siberia. Precambrian Research, 73:251-270. 
Kouchinsky, A.V. 1999. Shell microstructures of the Early Cambrian Anabarella and Watsonella as new evidence on the origin of the Rostroconchia. Lethaia, 32:173-180.

Kouchinsky, A.V. 2000. Shell microstructures in Early Cambrian mollusks. Acta Palaeontologica Polonica, 45(2):119-150.

Kouchinsky, A.V., Bengtson, S., Runnegar, B., Skovsted, C., Steiner, M., and Vendrasco, M. 2012. Chronology of early Cambrian biomineralisation. Geological Magazine, 149(2):221-251.

Kruse, P.D. 1997. Hyolith guts in the Cambrian of northern Australia - turning hyolithomorphs up-side down. Lethaia, 29:213-217.

Kruse, P.D., Zhuravlev, A.Y., and James, N.P. 1995. Primordial metazoan-calcimicrobial reefs: Tommotian (early Cambrian) of the Siberian platform. Palaios, 10:291-321.

Kuhn, O. 1949. Lehrbuch der Paläozoologie. E. Schweizerbart. Stuttgart V.

Küster, H.C. and Clessin, S. 1889. Die Familie Mytilidae, p. 1-170. In Küster, H.C. and Kobelt, W. (eds.), Abbildungen nach der Natur mit Beschreibungen, Systematisches Conchylien-Cabinet von Martini und Chemnitz. Nürnberg.

Landing, E. 1988. Lower Cambrian of eastern Massachusetts: stratigraphy and small shelly fossils. Journal of Paleontology, 62:661-695.

Landing, E. 1989. Paleoecology and distribution of the Early Cambrian rostroconch Watsonella crosbyi Grabau. Journal of Paleontology, 63(5):566-573.

Landing, E. and Bartowski, K.E. 1996. Oldest shelly fossils from the Taconic allochthon and late early Cambrian sea-levels in eastern Laurentia. Journal of Paleontology, 70(5):741-761.

Landing, E., Peng, S.C., Babcock, L.E., and Moczydłowska-vidal, M. 2007.Global standard names for the lowermost Cambrian Series and Stage. Episodes, 30:283-289.

Landing, E., Myrow, P., Benus, A.P., and Narbonne, G.M. 1989. The Placentian Series: appearance of the oldest skeletalized faunas in southeastern Newfoundland. Journal of Paleontology, 63(6):739-769.

Li, G. and Xiao S. 2004. Tannuolina and Micrina (Tannuolinidae) from the Lower Cambrian of eastern Yunnan, south China, and their scleritome reconstruction. Journal of Paleontology, 78(5):900913.

Li, G., Zhao, X., Gubanov, A., Zhu, M., and Na, L. 2011. Early Cambrian mollusc Watsonella crosbyi: a potential GSSP index fossil for the base of the Cambrian Stage 2. Acta Geologica Sinica, 85(2):309-319.

Liu, D.Y. 1979. Earliest Cambrian brachiopods from southwest China. Acta Palaeontologica Sinica 18:505-512 (in Chinese with English abstract).

Liu, D.Y. 1987. Brachiopods and tommotiids near Precambrian-Cambrian boundary in SW China, p. 345400. In Zhang, W.T. (ed.), Stratigraphy and Paleontology of Systemic Boundaries in China: Precam-
brian-Cambrian Boundary. Nanjing Institute of Geology and Paleontology, Academica Sinica (compiled), Nanjing University Publishing House, Nanjing, China.

López Díaz, F. 1994. Estratigrafía de los materiales anteordovícicos del anticlinal de Navalpino (Zona CentroIbérica). Revista de la Sociedad de Geología Española, 7:31-45.

Lu, Y. 1979. Cambrian mineral deposits in China and the bio-environmental control hypothesis. The Geological Publishing House, Peking. (In Chinese)

Luo, H., Jiang, Z., and Tang, L. 1994. Stratotype section for Lower Cambrian stages in China. Yunnan Science and Technology Press, Kunming. (In Chinese)

Luo, H., Jiang, Z., Wu, X., Song, X., and Ouyang, L. 1982. The Sinian-Cambrian boundary in eastern Yunnan, China. Yunnan Institute of Geological Sciences. (In Chinese with English abstract)

Luo, H., Jiang, Z., Xu, Z., Song, X., and Xue, X. 1980. On the Sinian-Cambrian boundary of Meishucun and Wangjiawan, Jinning county, Yunnan. Acta Geologica Sinica, 54(2):95-111. (In Chinese with English abstract)

Luo, H., Jiang, Z., Wu, X., Song, X., Ouyang, L., Xing, Y., Liu, G., Zhang, S., and Tao Y. 1984. Sinian-Cambrian Boundary stratotype section at Meishucun, Jinning, Yunnan, China. Peoples Publishing House, Yunnan. (In Chinese with English abstract)

MacKinnon, D.I. 1985. New Zealand late Middle Cambrian molluscs and the origin of Rostroconchia and Bivalvia. Alcheringa, 9(1/2):65-81.

Malinky, J.M. 1987. Taxonomic revision of Lower and Middle Paleozoic Orthothecida (Hyolitha) from North America and China. Journal of Paleontology, 6:942959.

Malinky, J.M. and Skovsted, C.B. 2004. Hyoliths and Small Shelly Fossils from the lower Cambrian of north-east Greenland. Acta Palaeontologica Polonica, 49(4):551-578.

Mambetov, A.M. 1988. New representatives of mollusks and conodontomorphs from the Lower and Middle Cambrian of the Tien Shan and the Lesser Karatau Range, p. 148-154. In Zhuravleva, I.T. and Repina, L.N. (eds.), Cambrian of Siberia and Central Asia. Proceedings of the Institute of the Geology and Geophysics of the Siberian Division of the Academy of Sciences of the USSR 720, Nauka, Moscow. (In Russian)

Marek, L. 1963. New knowledge on the morphology of Hyolithes. Sbornlk Geologickych Fed, Paleontologie, 1:53-74.

Marek, L. 1966. New hyolithid genera from the Ordovician of Bohemia. Casopis Naradniho Muzea, 135:8992.

Marek, L. and Yochelson, E.L. 1964. Paleozoic mollusk: Hyolithes. Science, 146:1674-1675.

Marek, L. and Yochelson, E.L. 1976. Aspects of the biology of Hyolitha (Mollusca). Lethaia, 9:65-82. 
Matthew, G.F. 1886. Illustrations of the fauna of the St. John Group, No. 3 - Descriptions of new genera and species. Transactions, Royal Society of Canada, 3(4):29-84.

Matthew, G.F. 1899. Studies on Cambrian faunas, No. 3. Transactions, Royal Society of Canada, 2nd series, 5(4):39-123.

Matthews, S.C. and Missarzhevsky, V.V. 1975. Small Shelly Fossils of late Precambrian and early Cambrian age: a review of recent work. Journal of the geological Society of London, 131:989-304.

Meshkova, N.P. 1969. On the paleontological characterization of the Lower Cambrian deposits of the Siberian platform, p. 158-174. In Zhuravleva, I.T. (ed.), Biostratigraphy and Paleontology of the Lower Cambrian of Siberia and the Russian Far East. Nauka, Moscow. (In Russian)

Meshkova, N.P. 1974. Cambroscleritida incertae sedis A new Order of Cambrian fossils, p. 190-193. In Zhuravleva, I.T. and Rozanov, A.U. (eds.), Biostratigraphy and Paleontology of the Lower Cambrian of Europe and Northern Asia. Nauka, Moscow. (In Russian)

Michel-Levy, A. 1932. Existence de formations antécambriennes dans la Montagne Noire (Hérault). Comptes-Rendus de l'Académie des Sciences, Paris.

Missarzhevsky, V.V. 1974. New data on the oldest fossils of the early Cambrian of the Siberian platform, $p$. 179-189. In Zhuravleva, I.T. and Rozanov, A.Y. (eds.), Biostratigraphy and Paleontology of the Lower Cambrian of Europe and Northern Asia. Nauka, Moscow. (In Russian)

Missarzhevsky, V.V. 1980. Early Cambrian mongolian Hyolitha and Gastropoda. Paleontological Journal, 15(1):18-25.

Missarzhevsky, V.V. 1981. Early Cambrian hyoliths and gastropods of Mongolia. Paleontological Journal, 1:21-28.

Missarzhevsky, V.V. 1989. Oldest skeletal fossils of late Precambrian and early Cambrian age: a review of recent work. Trudy Geologicheskogo Instituta AN SSSR, 443:1-231. (In Russian)

Missarzhevsky, V.V. and Mambetov, A.M. 1981. Stratigrafiya i fauna pogranichnykh sloyev Kembriya i Dokembriya Malogo Karatau [Stratigraphy and fauna of the Precambrian-Cambrian boundary beds of the Malyy Karatau]. Trudy Ordena Trudovogo Krasnogo Znameni Geologicheskiy Institut Akademiya Nauka SSSR, 326:1-90. (In Russian)

Moberg, J.C. 1892. Om den af Trinucleus coscinorrliinus Ang. karakteriserade kalkens geologiska alder. Geologi foreniiigens i Stockholm Forhncll. Bd. 14.

Mostler, H. 1980. Zur Mikrofauna des Unterkambriums in der Haziraformation - Hazara, Pakistan. Annalen des Naturhistorisches Museum in Wien, 83:245-257.
Müller, K.J. 1975. "Heraultia" varensalensis COBBOLD (Crustacea) aus dem unteren Kambrium, der älteste Fall von Geschlechtsdimorphismus. Paläontologische Zeitschrift, 49:168-180.

Murphy, M.A. and Salvador, A. 1999. International Stratigraphic Guide - An abridged version. Episodes, 20(1):255-271.

Palacios, T. and Vidal, G. 1992. Lower Cambrian acritarchs from northern Spain: the PrecambrianCambrian boundary and biostratigraphic implications. Geological Magazine, 129:421-436.

Parkhaev, P.Y. 2000. The functional morphology of the Cambrian univalved mollusks-Helcionellids 1. Paleontological Journal, 34(4):392-399.

Parkhaev, P.Y. 2001. The functional morphology of the Cambrian univalved mollusks-Helcionellids 2. Paleontological Journal, 35(5):470-475.

Parkhaev, P.Y. 2002. Phylogenesis and the system of the Cambrian univalved mollusks. Paleontological Journal, 36(1): 25-36.

Parkhaev, P.Y. 2004. New data on the morphology of shell muscles in Cambrian helcionelloid mollusks. Paleontological Journal, 38(3):254-256.

Parkhaev, P.Y. 2005. Cambrian helcionelloid mollusks as the foundation of evolution in the class Gastropoda, p. 63-84. In Modern Russian Paleontology: Classical and Recent Methods. Paleontological Institute of the Russian Academy of Science, Moscow. (In Russian)

Parkhaev, P.Y. 2006. On the genus Auricullina Vassiljeva, 1998 and shell pores of the Cambrian helcionelloid mollusks. Paleontological Journal, 40(1):20-32.

Parkhaev, P.Y. 2008. The early Cambrian radiation of Mollusca, p. 33-69. In Ponder, W. and Lindberg, D. (eds.), Phylogeny and Evolution of Molluscs. University of California Press, Berkeley.

Parkhaev, P.Y. and Demidenko, Y.E. 2010. Zooproblematica and Mollusca from the Lower Cambrian Meishucun section (Yunnan, China) and taxonomy and systematics of the Cambrian Small Shelly Fossils of China. Paleontological Journal, 44(8):883-1161.

Parkhaev, P.Y. and Karlova, G.A. 2011. Taxonomic revision and evolution of Cambrian mollusks of the genus Aldanella Vostokova, 1962 (Gastropoda, Archaeobranchia). Paleontological Journal, 45(10):1145-1205.

Parkhaev, P.Y., Karlova, G.A., and Rozanov A.Y. 2011. Taxonomy, stratigraphy and biogeography of Aldanella attleborensis - a possible candidate for defining the base of Cambrian Stage 2. Museum of Northern Arizona Bulletin, 67:298-300.

Parkhaev, P.Y., Karlova G.A., and Rozanov A.Y. 2012. Stratigraphic distribution of two potential species for the GSSP of Cambrian Stage 2 - Aldanella attleborensis and Watsonella crosbyi. Journal of Guizhou University, 29(1):179-180.

Peel, J.S. 1988. Molluscs of the Holm Dal Formation (late Middle Cambrian), central north Greenland. Meddelelser om Grønland, Geoscience, 20:145-168. 
Peel, J.S. 1991. Functional morphology of the Class Helcionelloida nov., and the early evolution of the Mollusca, p. 157-177. In Simonetta, A. M. and Conway Morris, S. (eds.), The Early Evolution of Metazoa and the Significance of Problematic Taxa. Cambridge: Cambridge University Press.

Peel, J.S. and Skovsted, C.B. 2005. Problematic capshaped fossils from the lower Cambrian of north-east Greenland. Paläontologische Zeitschrift, 79:461-470.

Pelman, Y.L., Jermak, V.V., Fedorov, A.B., Luchinina, V.A., Zhuravleva, I.T., Repina, L.N., Bondarev, V.I., and Borodaevskaya, Z.V. 1990. New data on the stratigraphy and paleontology of the Upper Precambrian and Lower Cambrian of the Dzhanda River (right-bank tributary of the Aldan River), p. 3-32. In Repina, L.N. (ed.), Biostratigraphy and Paleontology of the Cambrian of Northern Asia. Proceedings of the Institute of the Geology and Geophysics of the Siberian Division of the Academy of Sciences of the USSR 765 (In Russian).

Peng, S.C. and Babcock, L.E. 2011. Continuing progress on chronostratigraphic subdivision of the Cambrian System. Bulletin of Geosciences, 86(3):391-396.

Perconig, E., Vázquez, F., Velando, F., and Leyva, F. 1986. Proterozoic and Cambrian phosphorites deposits: Fontanarejo, Spain, p. 220-234. In Cook, P.J. and Shergold, J.H. (eds.), Phosphate Deposits of the World. Vol. 1. Proterozoic and Cambrian Phosphorites. Cambridge Univ. Press, Cambridge.

Pojeta, J.J. 1987. Phylum Hyolitha, p. 436-444. In Boardman, R.S. Cheetham A.H., and Rowell A.J. (eds.), Fossil invertebrates. Blackwell, Palo Alto.

Pojeta, J.J. and Runnegar, B. 1976. The palaeontology of rostroconch mollusks and the early history of the phylum Mollusca. Geological Survey Professional Paper, 968:1-88.

Pojeta, J.J., Runnegar, B., Morris, N.J., and Newell, N.D. 1972. Rostroconchia: a new class of bivalved mollusks. Science, New Series, 177(4045):264-267.

Ponder, W.F., Parkhaev, P.Y., and Beechey, D.L. 2007. A remarkable similarity in scaly shell structure in early Cambrian univalved limpets (Monoplacophora; Maikhanellidae) and a recent fissurellid limpet (Gastropoda: Vetigastropoda) with a review of Maikhanellidae. Molluscan Research, 27(3):153-163.

Popov, L.E. and Holmer, L.E. 1994. Cambrian-Ordovician lingulate brachiopods from Scandinavia, Kazakhstan, and south Ural Mountains. Fossils and Strata, 35:1-156.

Pospelov, A.G., Pelman, Y.L., Zhuravleva, I.T., Luchinina, V.A., Kuznetsova, V.G., Esakova, N.V., Ermak, V.V., and Akasarina, N.A. 1995. Biostratigraphy of the Kiya River section. Annales de Paléontologie, 81(4):169246.

Poulsen, C. 1967. Fossils from the Lower Cambrian of Bornholm. Danske Videnskabernes Selskab, Matematisk-Fysiske Meddelelser, 36(2):1-48.
Qian, Y. 1977. Hyolitha and some problematica from the Lower Cambrian Meishucun Stage in central and SW China. Acta Palaeontologica Sinica, 16(2):255-278. (In Chinese with English abstract)

Qian, Y. 1978a. The early Cambrian hyolithids in central and southwest China and their stratigraphical significance. Memoirs of the Nanjing Institute of Geology and Palaeontology, Academia Sinica, 11:1-37. (In Chinese with English abstract)

Qian, Y. 1978b. Hyoliths, Worms, Poriferans, p. 127-138. In Hubei Bureau of Geology, Stratigraphic Researh Group of Yangtze Gorges (ed.), Stratigraphy and Palaeontology of Sinian to Permian in the Eastern Part of the Yangtze Gorge. Geological Publishing House, Beijing. (In Chinese with English abstract)

Qian, Y. 1984. Several groups of bizarre sclerite fossils from the earliest Cambrian in eastern Yunnan. Bulletin of the Nanjing Institute of Geology and Palaeontology, Academia Sinica, 6:87-99. (In Chinese with English abstract)

Qian, Y. 1989. Early Cambrian Small Shelly Fossils of China with special reference to the PrecambrianCambrian boundary. In Stratigraphy and Palaeontology of Systemic Boundaries in China: PrecambrianCambrian Boundary. Nanjing University Publishing House, Nanjing, Vol. 2.

Qian, Y. and Bengtson, S. 1989. Palaeontology and biostratigraphy of the early Cambrian Meishucunian Stage in Yunnan province, south China. Fossils and Strata, 24:1-156.

Qian, Y. and Xiao, B. 1984. An Early Cambrian small shelly fauna from Aksu-Wushi region, Xinjiang. Professional Papers of Stratigraphy and Palaeontology, 13:65-90. (In Chinese with English abstract)

Qian, Y. and Yin, G. 1984. Small Shelly Fossils from the lowest Cambrian in Guizhou. Professional Papers of Stratigraphy and Palaeontology, 13:91-124. (In Chinese with English abstract)

Qian, Y. and Zhang, S. 1983. Small Shelly Fossils from the Xihaoping Member of the Congying Formation in the Fangxian county of Hubei province and their stratigraphical significance. Acta Palaeontologica Sinica, 2(1): 83-94. (In Chinese with English abstract)

Qian, Y. and Zhang, S. 1985. On the systematic position of small orthoconic fossils with bulbous initial part from the early lower Cambrian. Acta Micropalaeontologica Sinica, 2(1):1-13. (In Chinese)

Qian, Y., Chen, M., and Chen, Y.Y. 1979. Hyolithids and other Small Shelly Fossils from the Lower Cambrian Huangshandong Formation in the eastern part of the Yangtze Gorge. Acta Palaeontologica Sinica, 18(3):207-230. (In Chinese with English abstract)

Qian, Y., Yin, G.Z., and Xiao, B. 2000. Opercula of hyoliths and operculum-like fossils from the Lower Cambrian Yuertus Formation, Xinjiang. Acta Micropalaeontologica Sinica, 17(4):404-415. (In Chinese with English abstract) 
Qian, Y., Zhu, M.Y., He, T.G., and Jiang, Z. W. 1996. New investigation of Precambrian-Cambrian boundary sections in eastern Yunnan. Acta Micropalaeontologica Sinica, 13(3):225-240. (In Chinese with English abstract)

Qian, Y., Van Iten, H., Cox, R.S., Zhu, M.Y., and Zhuo, E.J. 1997. A brief account of Emeiconularia trigemme, a new genus and species of protoconulariid. Acta Micropalaeontologica Sinica, 14(4):475-488. (In Chinese with English abstract)

Robinson, R.A. 1964. Late Middle Cambrian faunas from western Utah. Journal of Paleontology, 38(3):510566.

Rolet, J. 1973. Contribution à l'étude géologique des monts de l'Est de Lacaune (autochtone du Mendic et écaille de Marcou), Montagne Noire, France. Unpublished PhD thesis, Orsay, France.

Rowland, S.M. and Shapiro, R.S. 2002. Reef patterns and environmental influences in the Cambrian and earliest Ordovician, p. 95-128. In Kiessling, W., Flügel, E., and Golonka, J. (eds.), Phanerozoic Reef Patterns. SEPM, Special Publication, 72.

Rowland, S.M., Luchinina, V.A., Korovnikov, I.V., Sipin, D.P., Tarletskov, A.I., and Fedoseev, A.V. 1998. Biostratigraphy of the Vendian-Cambrian Sukharikha River section, northwestern Siberian platform. Canadian Journal of Earth Sciences, 35(4):339-352.

Rozanov, A.Y. 1984. The Precambrian-Cambrian boundary in Siberia. Episodes, 7(1):20-24.

Rozanov, A.Y. and Missarzhevsky, V.V. 1966. Biostratigraphy and fauna of the lower Horizons of the Cambrian. Proceedings of the Geological Institute of the Academy of Sciences of the USSR, Nauka, Moscow, 148 (in Russian).

Rozanov, A.Y. and Sokolov, B.S. 1983. Stage Subdivisions of the Lower Cambrian, Stratigraphy. Nauka, Moscow. (In Russian)

Rozanov, A.Y., Zhu, M., Pak, K.L., and Parkhaev, P.Y. 2008. The 2nd Sino-Russian Symposium on the Lower Cambrian subdivision. Paleontological Journal, 42(4):441-446.

Rozanov, A.Y., Missarzhevsky, V.V., Volkova, N.A., Voronova, L.G., Krylov, I.N., Keller, B.M., Korolyuk, I.K., Lendzion, K., Mikhnyar, R., Pykhova, N.G., and Sidorov A.D. 1969. Tommotskiu jarus i problema nizhney granisty Kembriya. Trudy Geoligske Institut Leningrad, 206:1-379. (In Russian)

Runnegar, B. and Jell, P.A. 1976. Australian Middle Cambrian molluscs and their bearing on early molluscan evolution. Alcheringa, 1(1/2):109-132.

Runnegar, B. and Jell, P.A. 1980. Australian Middle Cambrian molluscs: correction and additions. Alcheringa, 4(1/2):111-113.

Runnegar, B. and Pojeta, J.Jr. 1974. Molluscan phylogeny: the paleontological viewpoint. Science, 186(4161):311-317.
Runnegar, B. and Pojeta, J.Jr. 1985. Origin and diversification of the Mollusca, p. 1-57. In Trueman E.R. and Clarke M.R. (eds.), The Mollusca, Vol. 10: Evolution. Academic Press, New York.

Runnegar, B., Pojeta, J., Jr., Morris, N.J., Taylor, J.D., and Mcclung, G. 1975. Biology of the Hyolitha. Lethaia, 8:181-191.

Saito, K. 1936. Older Cambrian Brachiopoda, Gastropoda etc from north-western Korea. Journal of the Faculty of Science, Imperial University Tokyo, Section 2, 4:345-367.

Santamaría, J. 1996. Origen de los elementos fosfatados en los materiales precámbrico-cámbricos de la zona Centro-lbérica (España), p. 310-312. In Baldis, B. and Aceñolaza, F.G. (eds.), Early Paleozoic Evolution in NW Gondwana. Serie de Correlación Geológica 12. INSUGEO, Buenos Aires.

Shaler, N.S. and Foerste, A.F. 1888. Preliminary description of north Attleboro fossils. Harvard Museum of Comparative Zoology Bulletin, 16:27-41.

Singh, P. and Shukla, S.D. 1981. Fossils from the Lower Tal: their age and its bearing on the stratigraphy of the Lesser Himalayas. Geoscience Journal, 2:157176.

Skovsted, C.B. 2004. Mollusc fauna of the early Cambrian Bastion Formation of north-east Greenland. Bulletin of the Geological Society of Denmark, 51(1):11-37.

Sokolov, B.S. and Zhuravleva, I.T. 1983. Lower Cambrian stage subdivision of Siberia. Atlas of fossils. Transactions of the Institute of Geology and Geophysics of the Siberian Division of the Academy of Sciences of the USSR, 558:1-214. (In Russian)

Sokolov, B.S., Repina, L.N., Lazarenko, N.P., Meshkova, N.P., Korshunov, V.I., Nikiforov, N.I., and Aksarina, N.A. 1974. Lower Cambrian biostratigraphy and fauna of Kharaulakh, Tuora-Sis ridge. Transactions of the Institute of Geology and Geophysics of the Siberian Division of the Academy of Sciences of the USSR, 235:5-299. (In Russian)

Spizharski, T.N., Zhuravleva, I.T., Repina, L.N., Rozanov, A.Y., Tchernysheva, N.Y., and Ergaliev, G.H. 1986. The stage scale of the Cambrian System. Geological Magazine, 123:387-392.

Steiner, M., Li, G., Qian Y., and Zhu, M. 2004. Lower Cambrian Small Shelly Fossils of northern Sichuan and southern Shaanxi (China), and their biostratigraphic importance. Geobios, 37:259-275.

Steiner, M., Li, G., Qian Y., Zhu, M., and Erdtmann, B. D. 2007. Neoproterozoic to early Cambrian Small Shelly Fossil assemblages and a revised biostratigraphic correlation of the Yangtze platform (China). Palaeogeography, Palaeoclimatology, Palaeoecology, 254:67-99.

Sysoev, V.A. 1957. K morfologii, sistematischeskomupolozhennyv y sistematike kholitov. Proceedings of the USSR Academy of Science, Leningrad, 116(2):304-307. (In Russian) 
Sysoev, V.A. 1960. Mikrostruktura mkoviny khiolitov i ikh sistematicheskoe polozhenie. [Microstructure of hyolith shells and their systematic position]. Proceedings of the USSR Academy of Science, 131:1156-1158. (In Russian)

Thoral, M. 1935. Contributions à l'étude géologique des monts de Lacaune et des terrains cambriens et ordoviciens de la Montagne Noire. Bulletin du Service de la Carte Géologique de France, 192:318-637.

Topper, T.P., Brock, G.A., Skovsted, C.B., and Paterson, J.R. 2009. Shelly fossils from the lower Cambrian Pararaia bunyerooensis Zone, Flinders ranges, south Australia. Memoirs of the Association of Australasian Palaeontologists, 37:199-246.

Ushatinskaya, G.T. 1987. Neobychnye bezzamkovye brakhiopody iz nizhnego kembriya Mongolii. [Unusual inarticulate brachiopods from the Lower Cambrian of Mongolia.]. Paleontologicheskij Zhurnal, 2:62-68. (In Russian)

Ushatinskaya, G.T. and Parkhaev, P.Y. 2005. Preservation of imprints and casts of cells of the outer mantle epithelium in the shells of Cambrian brachiopods, mollusks, and problematics. Paleontological Journal, 39(3):251-263.

Valkov, A.K. 1975. Biostratigraphy and Hyoliths of the Cambrian of the Northeastern Siberian Platform. Nauka, Novosibirsk. (In Russian)

Valkov, A.K. 1987. The biostratigraphy of the Lower Cambrian of the Siberian Platform. Yudomo-Olenek Region. Nauka, Moscow. (In Russian)

Valkov, A.K. and Karlova, G.A. 1984. Fauna from the Vendian-Cambrian transition beds in the lower reaches of the Gonam River, p. 12-41. In Stratigraphy of the Late Precambrian and Early Paleozoic: Central Siberia. Institute of Geology and Geophysics, Academy of Science USSR, Novosibirsk. (In Russian)

Valkov, A.K. and Karlova, G.A. 1986. Fauna from transitional Vendian-Cambrian layers of lower River Gonam. Institute of Geology and Geophysics, Academy of Science USSR, Novosibirsk:1-147. (In Russian)

Valkov, A.K., Meshkova, N.P., Missarzhevsky, V.V., and Sysoev V.A. 1983. Tip Hiolitozoa. [Phylum Hyolithozoes]. Institute of Geology and Geophysics, Academy of Science USSR, Moscow, 558:54-96 (in Russian).

Valladares, M.I., Barba, P., and Ugidos, J.M., 2002. Precambrian, p. 7-16. In Gibbons, W. and Moreno, T. (eds.), The Geology of Spain. Publications of the Geological Society, London.

Valladares, M.I., Barba, P., Ugidos, J.M., Colmenero, J.R., and Armenteros, I. 2000. Upper Neoproterozoic-Lower Cambrian sedimentary successions in the Central Iberian zone (Spain): sequence stratigraphy, petrology and chemostratigraphy. Implications for other European zones. International Journal of Earth Sciences, 89:2-20.
Vassiljeva, N.I. 1990. New Early Cambrian gastropod mollusks from the Siberian platform and some questions of their systematics, p. 4-21. In Microfauna of the USSR: Systematic and Biostratigraphic Questions. Vseross. Nauchno-Issled. Geologorazv. Neft. Inst. (VNIGRI), Leningrad. (In Russian)

Vassiljeva, N.I. 1998. Small shelly fauna and biostratigraphy of the Lower Cambrian of the Siberian platform. Vseross. Nauchno-Issled. Geologorazv. Neft. Inst. (VNIGRI), St. Petersburg. (In Russian)

Vendrasco, M.J., Li, G., Porter S.M., and Fernandez, C.Z. 2009. New data on the enigmatic OcruranusEohalobia group of early Cambrian small skeletal fossils. Palaeontology, 56(6):1373-1396.

Vendrasco, M.J., Porter, S.M., Kouchinsky, A., Li, G., and Fernandez, C.Z. 2010. New data on molluscs and their shell microstructures from the Middle Cambrian Gowers Formation, Australia. Palaeontology, 53(1):97-135.

Vidal, G., Palacios, T., Gámez-Vintaned, J.A., Díez Balda, M.A., and Grant, S.W.F. 1994. Neoproterozoic-early Cambrian geology and paleontology of Iberia. Geological Magazine, 131:729-765.

Villeneuve, J. 1920. Dipteres palearctiques nouveaux ou peu connus. Annales de la Société Entomologique, 60:114-120.

Vinther, J. and Nielsen, C. 2005. The Early Cambrian Halkieria is a mollusc. Zoologica Scripta, 34(1):8189.

Voronin, Y.I., Voronova, L.G., Grigorjeva, N.V., Drozdova, N.A., Zhegallo, E.A., Zhuravlev, A.Y., Ragozina, A.L., Rozanov, A.Y., Sayutina, T.A., Sysoev, V.A., and Fonin, V.D. 1982. Granitsa dokem briya i kembriya v geosinklinal'nvkh oblastyakh (opornyj razrez SalanyGol, MNR). [The Precambrian-Cambrian boundary in the geosynclinal areas (the reference section of Salany-Gol, MPR)]. Trudy Sovmestnoj SovetskoMongol'skoj Paleontologirhes/wj Ehkspeditsii, Nauka, Moscow, 18:1-150. (In Russian).

Vostokova, V.A. 1962. Cambrian gastropods from Siberian platform and Taimyr. Statei po Paleontologii $i$ Biostratigrafii, 28:51-74. (In Russian)

Walcott, C.D. 1890. Descriptive notes of new genera and species from the Lower Cambrian or Olenellus zone of North America. Proceedings of the United States National Museum, 12:33-46.

Wang, B. 1994. New mollusks and problematic fossils from the Lower Cambrian of China. Paleontological Journal, 28(4):10-17.

Wang, Y., Yin, G., Zheng, S., and Qian, Y. 1984. Stratigraphy of the boundary Sinian-Cambrian in the Yangtze area of Guizhou, p. 1-31. In The Upper Precambrian and Sinian-Cambrian boundary in Guizhou. People's Publishing House, Guizhou. (In Chinese with English abstract)

Wenz, 1938. Handbuch der Paläozoologie: Gastropoda. Handbuch der Paläozoologie. 
Williams, A., Carlson, S.J., Brunton, C.H.C., Holmer, L.E., and Popov, L.E. 1996. A supra-ordinal classification of the Brachiopoda. Philosophical Transactions of the Royal Society of London, Series B, 351:1117-1193.

Williams, A., Carlson, S.J., Howard, C., and Brunton, C.H.C. 1997. Linguliformea, Craniiformea, and Rhynchonelliformea, p. H193-H200. In Williams, A., Brunton, C.H.C., and Carlson, S.J. (eds.) Treatise on Invertebrate Paleontology, Part H, Brachiopoda. Geological Society of America and University of Kansas Press, Boulder, Colorado, and Lawrence, Kansas, 1-919.

Wrona, R. 1989. Cambrian Limestone Erratics in the Tertiary Glacio-Marine Sediments of King George Island, west Antarctica. Polish Polar Research, 10(4):533-553.

Wrona, R. 2004. Cambrian microfossils from glacial erratics of King George Island, Antarctica. Acta Palaeontologica Polonica, 49(1):13-56.

Xiang, L.W., Nan, R.S., Guo, Z.M., Li, S.J., Yang, J.L., Zhou, G.Q., Sheng, X.F., Qian, Y.A., Yuan, K.X., and Zhang S.G. 1981. Stratigraphy of China, 4, the Cambrian System of China. Geological Publishing House, Beijing. (In Chinese)

Xing, Y., Ding, Q., and Luo, H. 1982. Biotic characteristics of the Sinian-Cambrian boundary beds in China and the boundary problems. Precambrian Research, 17(2):77-85. (In Chinese with English abstract)

Xing, Y., Ding, Q., Luo, H., He, T., and Wang, Y. 1984. The Sinian-Cambrian boundary of China and its related problems. Geological Magazine, 121(3):155170. (In Chinese with English abstract)

Yang, X., He, Y., and Deng, S. 1983. On the SinianCambrian boundary and the Small Shelly Fossils assemblages in Nanjiang area, Sichuan. Bulletin of the Chengdu Institute of Geology and Mineral Resources, 4:91-110. (In Chinese).

Yin, J., Ding, L., He, T., Li, S., and Shen, L. 1980. The palaeontology and sedimentary environment of the Sinian System in Emei-Ganluo area, Sichuan. People's Publishing House, Sichuan:1-268. (In Chinese with English abstract)

Yu, W. 1974. Cambrian Gastropoda. In Handbook of the Stratigraphy and Paleontology of Southwest China. Science Press, Beijing. (In Chinese)

Yu, W. 1979. Earliest Cambrian monoplacophorans and gastropods from western Hubei with their biostratigraphical significance. Acta Palaeontologica Sinica, 18(3):233-270. (In Chinese with English abstract)

Yu, W. 1981. New earliest Cambrian monoplacophorans and gastropods from W. Hubei and E. Yunnan. Acta Palaeontologica Sinica, 20(6):552-556. (In Chinese with English abstract)

Yu, W. 1983. A study on the earliest Cambrian molluscan faunas of Yangtze region in China. Chinese Science Bulletin, 28:1572. (In Chinese with English abstract)
Yu, W. 1984a. On merismoconchids. Acta palaeontologica sinica, 23(4): 432-446. (In Chinese with English abstract)

Yu, W. 1984b. Early Cambrian molluscan faunas of Meishucun Stage with special reference to PrecambrianCambrian boundary, p. 21-33. In Academia Sinica Developments in Geoscience. Contribution to 27th International Geological Congress, Moscow. Science Press, Beijing. (In Chinese)

Yu, W. 1987a. New molluscan materials of the Tethys: $p$. 51-59. In International Symposium on Shallow Tethys 2. Wagga Wagga, Balkema, Rotterdam.

Yu, W. 1987b. Yangtze micromolluscan fauna in Yangtze region of China with notes on Precambrian-Cambrian boundary, p. 19-275. In Stratigraphy and palaeontology of systemic boundaries in China. PrecambrianCambrian boundary (1), Nanjing University Publishing House.

Yu, W. 1988. New Advances in the study of earliest Cambrian molluscan fauna of China. Chinese Science Bulletin, 33(18): 1555-1557. (In Chinese with English abstract)

Yu, W. 1990. The First radiation of shelled mollusks. Palaeontologica Cathayana, 5:139-170.

$\mathrm{Yu}$, W. 1993. On the different affinities between Yangtzechiton $\mathrm{Yu}$ and Paracarinachites Qian et Jiang. Acta Micropalaeontologica Sinica, 10(3):307-316. (In Chinese with English abstract)

Yu, W. 2001. The earliest Cambrian polyplacophorans from China. Records of the Western Australian Museum, 20:167-185.

Yu, W. 2005. The bivalve Yangtzedonta is not the brachiopod Xianfengella. Acta Geologica Sinica, 79(6):770-776.

$\mathrm{Yu}, \mathrm{W} .2008$. On the genus Yangtzemerisma and related genera (Mollusca: Merismoconchia). Records of the Western Australian Museum, 24:181-194.

Yue, Z. and He, T.G. 1989. A restudy of some early Cambrian Small Shelly Fossils from Ganluo and Emei, Sichuan, southwest China. Acta Micropalaeontologica Sinica, 6(4):389-407.

Zhang, S. and Sun, C. 1991. Early Cambrian Small Shelly Fossils from Chaohu area, Anhui. Acta Micropalaeontologica Sinica, 8(1):19-40. (In Chinese)

Zhao, Z., Xing, Y., Ma, G., Yu, W., and Wang, Z. 1980. The Sinian System of eastern Yangtze Gorges, Hubei, p. 31-55. In Research on Precambrian Geology: Sinian Suberathem in China.Tianjin Science and Technology Press, Tianjin.

Zhegallo, E.A. 1983. Class Gastropoda, p. 96-100. In Sokolov, B. S. and Zhuravleva I. T. (eds.), Stage Subdivisions of the Lower Cambrian. Atlas of Fossils, Nauka, Moscow. (In Russian)

Zhong, H. 1977. Preliminary study on the ancient fauna of south China and its stratigraphic significance. Scientia Geologica Sinica, 2:118-128. (In Chinese) 
Zhou, B. and Xiao, L. 1984. Early Cambrian monoplacophorans and gastropods from Huainan and Huoqiu counties (Anhui province). Professional Papers of Stratigraphy, 13:125-140.

Zhu, M., Zhang, J., and Qian, Y. 2001. Sinian-Cambrian boundary stratigraphy at Gezhongwu, Zhijin county, Guizhou province, China: phosphorite and Small Shelly Fossils, p. 209-215. In Peng, S., Babcock, L.E., and Zhu, M. (eds.), Cambrian System of South China: Palaeoworld 13. University of Science and Technology China Press, Hefei.
Zhu, M.Y., Yang, A., Li, G., and Yuan, J. 2008. A working model for subdivision of the lower half Cambrian, $p$. 88-90. In Voronin, T. A. (ed.) ,13th International Field Conference of the Cambrian Stage Subdivision Working Group. The Siberian Platform, western Yakutia. SNIIGGiMS, Novosibirsk. 


\section{APPENDIX}

International correlation of Terreneuvian and Cambrian Series 2 (data for Siberia from Rozanov, 1984, Kouchinsky et al., 2001, Rozanov et al., 2008, Kouchinsky et al., 2012; data for Mongolia from Voronin et al., 1982, Brasier et al., 1996; Esakova and Zhegallo, 1996; data for Kazakhstan from Missarzhevsky and Mambetov, 1981; Holmer et al., 2001; Kouchinsky et al., 2011; data for Iran from Hamdi et al., 1989; data for Australia from Gravestock et al., 2001; Jenkins et al., 2002; Jago et al., 2006; Paterson and Brock, 2007; data for China from Xing, 1984; Steiner et al., 2007).

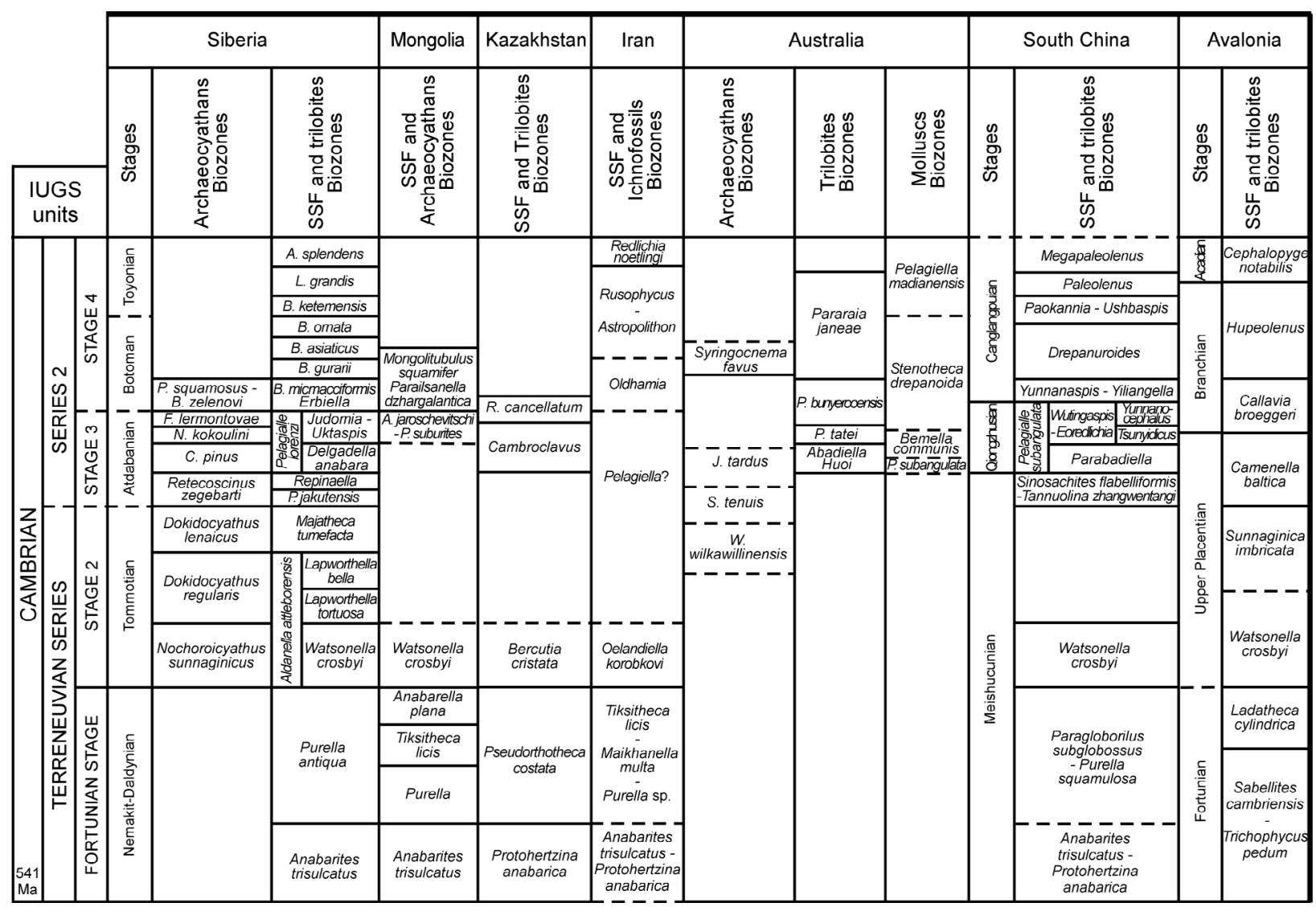

